\title{
Vegetation patterns and processes in semi-natural open habitats and the contribution of wild red deer to their conservation
}

\author{
Dissertation \\ zur Erlangung des mathematisch-naturwissenschaftlichen Doktorgrades \\ "Doctor rerum naturalium" \\ der Georg-August-Universität Göttingen
}

im Promotionsprogramm Biologische Diversität und Ökologie

der Georg-August University School of Science (GAUSS)

vorgelegt von

Friederike Riesch

aus Kassel

Göttingen, 2019 



\section{Betreuungsausschuss:}

Prof. Dr. Johannes Isselstein

Prof. Dr. Niko Balkenhol

Prof. Dr. Teja Tscharntke
Graslandwissenschaft, Department für Nutzpflanzenwissenschaften, Georg-August-Universität Göttingen Wildtierwissenschaften, Fakultät für Forstwissenschaften und Waldökologie, Georg-August-Universität Göttingen Agrarökologie, Department für Nutzpflanzenwissenschaften, Georg-August-Universität Göttingen

\section{Mitglieder der Prüfungskommission:}

Referent:

Korreferent:

2. Korreferent:
Prof. Dr. Johannes Isselstein

Prof. Dr. Niko Balkenhol

Prof. Dr. Gert Rosenthal

Landschafts- und Vegetationsökologie,

Universität Kassel

\section{Weitere Mitglieder der Prüfungskommission:}

Prof. Dr. Erwin Bergmeier

Prof. Dr. Christoph Leuschner

Prof. Dr. Matthias Waltert
Vegetationsanalyse \& Phytodiversität, Georg-August-Universität Göttingen

Pflanzenökologie und Ökosystemforschung, Georg-August-Universität Göttingen

Conservation Biology/Workgroup on Endangered Species,

Georg-August-Universität Göttingen 
"The more clearly we can focus our attention on the wonders and realities of the universe about us, the less taste we shall have for destruction."

—Rachel Carson (1954) 


\section{TABLE OF CONTENTS}

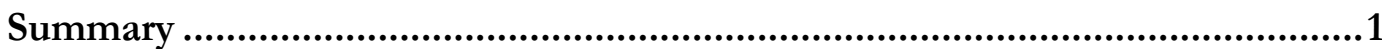

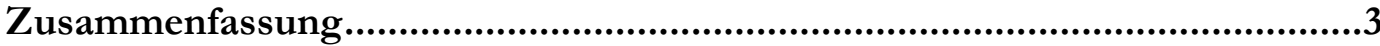

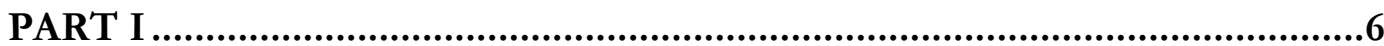

General Introduction .................................................................................6

The origin of semi-natural open habitats...............................................................

The conservation value of semi-natural open habitats ............................................. 7

The current situation of semi-natural grasslands and heathlands ............................... 8

Large herbivores in the conservation management of open habitats........................ 9

Red deer_candidates for wildlife conservation grazing? ............................................ 10

Military training areas — opportunities for science and conservation ....................... 11

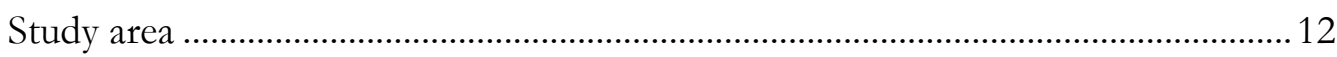

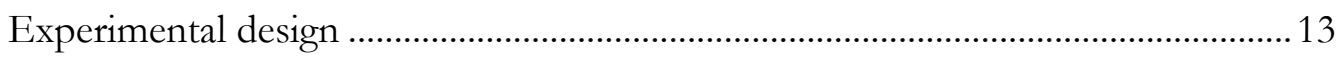

Research objectives and chapter outline ..................................................................... 14

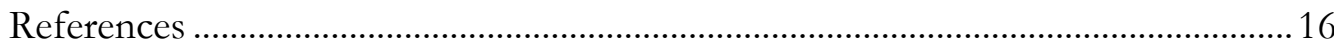

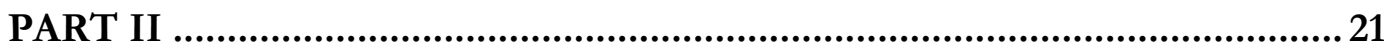

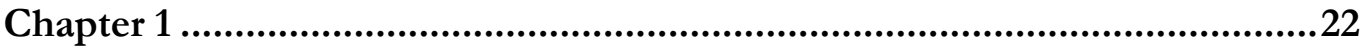

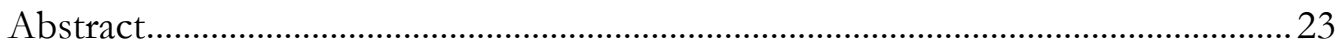

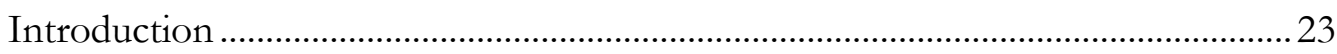

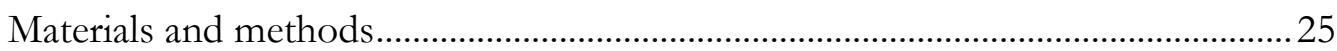

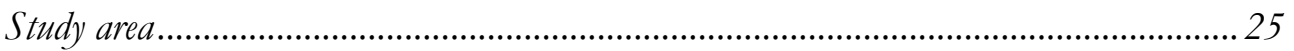

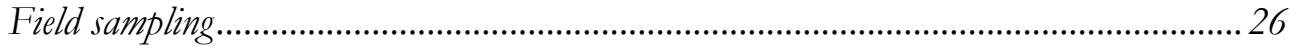

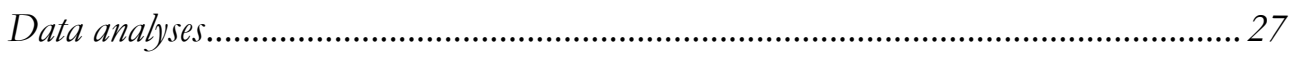

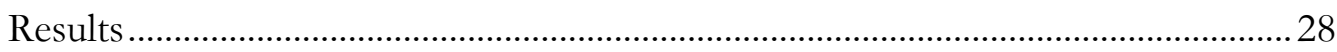

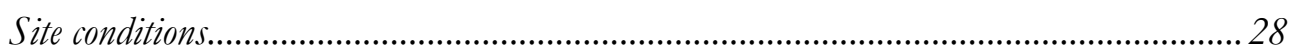

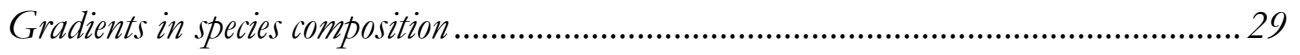

Effects of soil chemical parameters on species composition and richness ............................. 30

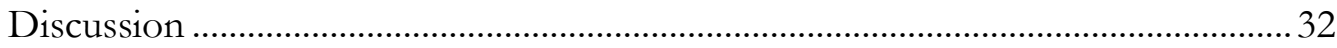

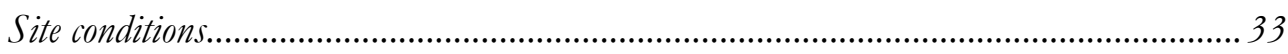

Main edaphic factors influencing plant species composition and richness in heathlands....... 33

Main edaphic factors influencing plant species composition and richness in grasslands........ 35

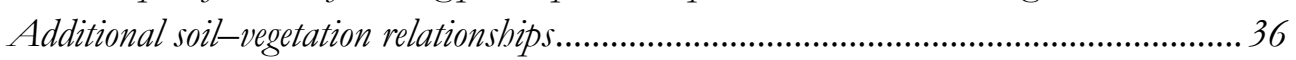

Functional gradients in species composition .............................................................. 36

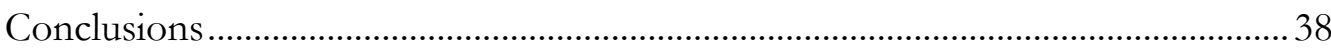

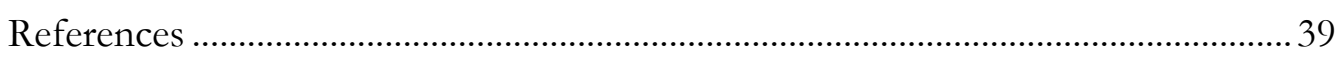

Supporting Information to the paper....................................................................... 44 


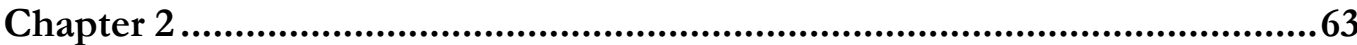

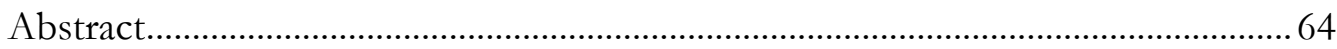

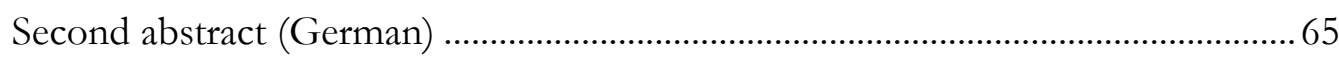

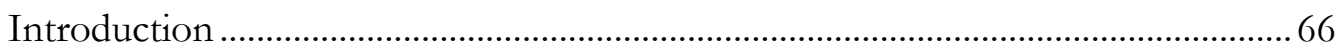

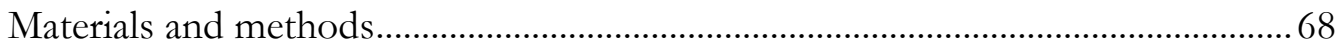

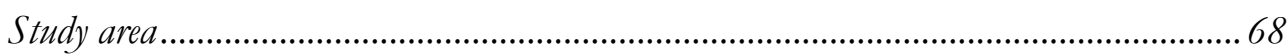

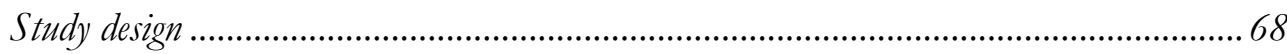

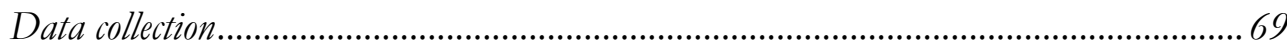

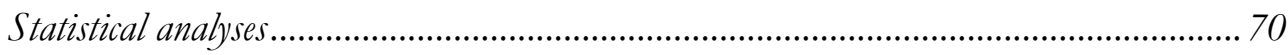

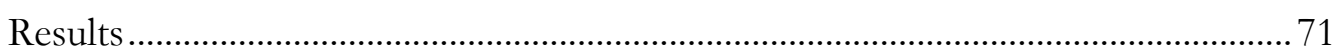

Seasonal variation in productivity, standing biomass and forage removal ........................... 71

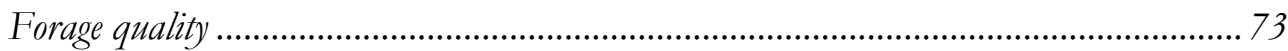

Forage removal in relation to environmental predictors................................................... 73

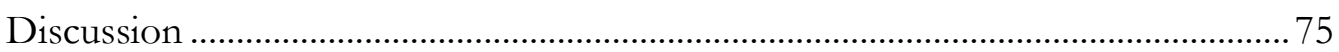

ANPP and forage removal by red deer in grasslands .................................................... 75

ANPP and forage removal by red deer in heathlands................................................ 76

Seasonal variability in forage quality and forage removal by red deer................................ 76

Management and drivers of forage removal by red deer................................................... 77

Opportunities and challenges for conservation .............................................................. 78

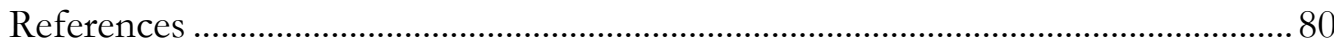

Supporting Information to the paper........................................................................... 83

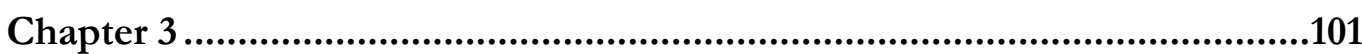

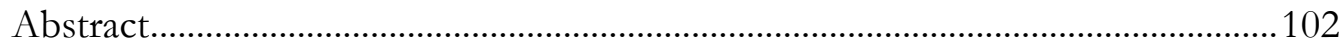

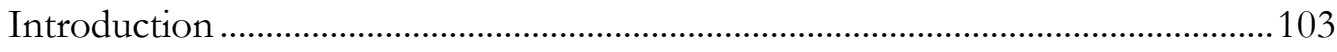

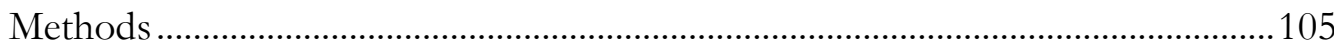

Study area

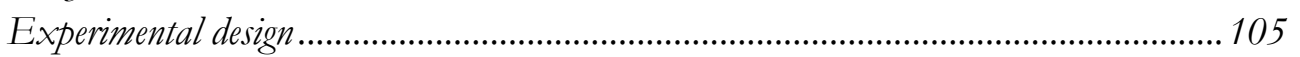

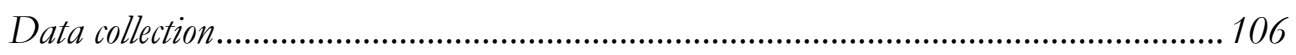

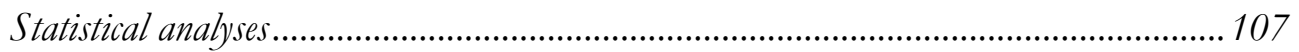

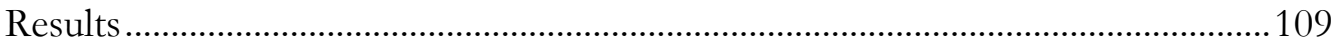

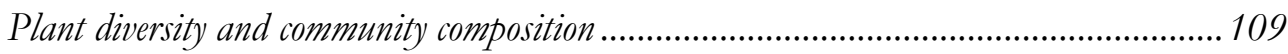

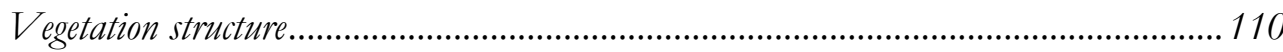

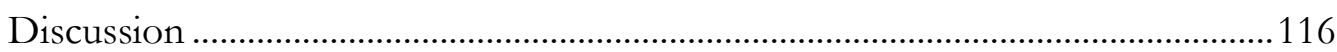

Red deer exclusion effects in grasslands ................................................................116

Interactions of red deer grazing with additional grassland management...........................117

Red deer exclusion effects in heathlands...................................................................... 117

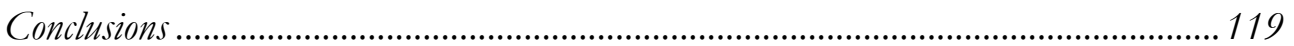

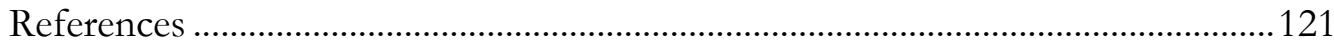

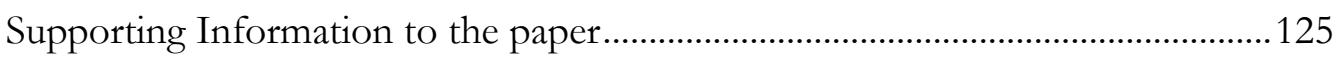




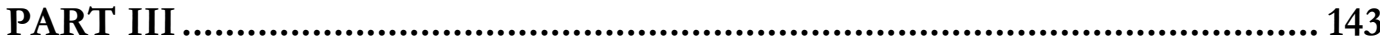

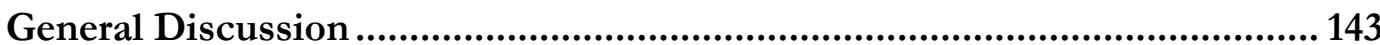

Soil-vegetation patterns in a pre-industrialised landscape ....................................144

Vegetation responses to grazing by wild red deer .....................................................144

Synergies between additional grassland management and red deer grazing.........146

Conservation grazing by wild red deer-future perspectives and open questions

Conclusions 150

References

Acknowledgements 155

Curriculum Vitae Error! Bookmark not defined.

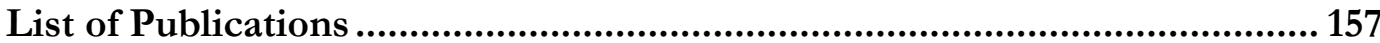

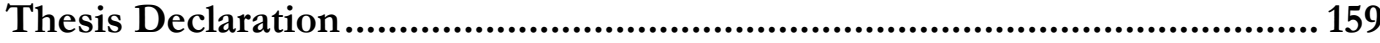





\section{Summary}

Traditional practices of human land use have shaped semi-natural open habitats over the past millennia, resulting in the typical European cultural landscapes with characteristic, diverse species communities. In the course of agricultural intensification during the twentieth century, however, areas extensively used, e.g. for pastoral farming, have declined immensely. At the same time, agriculturally suitable soils have been widely improved, especially by mineral fertilisation. This has been associated with widespread losses of plant diversity, as increasing nutrient availability promotes plant species that are strong competitors for light and thus increases the exclusion of less competitive species. Little is known about plant community patterns related to soil chemical parameters in open habitats where the soil nutrient status has not been anthropogenically enhanced.

In the absence of traditional agricultural land use, conservation management is required to remove biomass from open habitats in order to prevent secondary succession and related changes in plant communities. Extensive grazing with large domestic herbivores has proven beneficial to the maintenance of semi-natural open habitats. Under certain circumstances (e.g. large, inaccessible areas), however, livestock grazing is impossible. Therefore, there is a need to study if wild herbivores that do not require fencing, regular monitoring or veterinary treatment could be an alternative option for conservation grazing.

The present work took advantage of a study area where military land use has prevented agricultural intensification during the past century: the Grafenwöhr military training in north-eastern Bavaria, Germany. In this area, abundant wild and free-ranging red deer (Cervus elaphus) use the open land, such as semi-natural grasslands and heathlands, for foraging. Focusing on two exemplary Natura 2000 open habitat types (European dry heaths and lowland hay meadows), this thesis explores (i) the relationship between soil chemical parameters and vegetation patterns under nearly pre-industrialised soil conditions, and (ii) the interplay of grazing by free-ranging red deer and different vegetation processes.

Chapter 1 investigates how the naturally occurring variability in phosphorus and other soil chemical parameters relates to plant species community composition and richness in open habitats. In 2014, plant species composition was surveyed in 40 and 54 relevés in heathlands and grasslands, respectively. The insights provide valuable information about the sensitivity of different semi-natural habitats to changes in soil chemical parameters. Plant species richness increased with increasing soil $\mathrm{pH}$ in heathlands and decreased with increasing soil phosphorus concentration in grasslands. Therefore, in order to maintain suitable soil conditions for diverse plant communities in semi-natural open habitats, conservation management should take care to prevent further acidification in heathlands and even low phosphorus input in grasslands.

Chapter $2 \& 3$ look into the contribution of wild red deer to the maintenance of semi-natural grasslands and heathlands based on a grazing exclusion experiment 
running from 2015 to $2017 / 18$ on a subset of the sampling sites used in the 2014 plant survey. In order to assess synergistic effects between wildlife grazing and additional biomass removal measures (i.e. burning, mowing), the sampling sites in grasslands included burnt, mown and untreated treatment areas.

Chapter 2 analyses the dynamics of vegetation productivity, forage quality and biomass removal by red deer, using data from movable exclusion cages installed on open, continuously grazed plots and translocated five times per vegetation period. The amount of biomass annually removed by wild red deer was quantitatively similar to the forage removal by domestic grazing animals in stocking rates commonly used in conservation grazing. Despite the different productivity and grazing requirements of semi-natural grasslands and heathlands, biomass removal by red deer, with its habitat-type-specific seasonal variation, proved beneficial in both habitat types. Mowing, enhancing productivity and forage quality in the late season, increased the grassland attractiveness to red deer, and could therefore be a strategy to spatially direct the grazing activities by free-ranging red deer.

Comparing the vegetation development in open and permanently fenced plots in grasslands and heathlands, Chapter 3 studies how plant diversity and vegetation structure respond to the exclusion of red deer. Plant community composition diverged in open and fenced blots in both habitat types. In grasslands, plant species diversity was significantly reduced in fenced compared to open plots. Increasing height of sward and litter in both habitat types and, additionally, reduced cover of bare soil and increasing number of woody plant individuals in heathlands indicated beginning succession when red deer were excluded. In grasslands, the most pronounced differences between open and fenced plots occurred in the mown treatment, suggesting that red deer grazing combined with mowing could create particularly favourable conditions for grassland plant diversity.

Taken together, Chapter $\mathbf{2} \boldsymbol{\&} \mathbf{3}$ indicate that grazing by wild red deer could be useful to the conservation management of semi-natural open habitats, quantitatively - in terms of biomass removal — and qualitatively, providing benefits to vegetation structure and diversity. An adapted wildlife management that allows red deer to forage in open landscapes could therefore contribute to maintaining semi-natural open habitats and simultaneously reduce the potential for conflict between red deer and forestry. Integrating wild red deer into the conservation management seems promising and practicable in particular for large areas of conservation interest, such as core zones of national parks, wilderness areas or active and abandoned military training areas.

Overall, the insights from this thesis can contribute to developing suitable strategies for the conservation management of semi-natural open habitats to preserve their biodiversity and ecosystem services in times of increasing anthropogenic pressure on ecosystems. 


\section{Zusammenfassung}

Traditionelle Landnutzungspraktiken formten während der vergangenen Jahrtausende naturnahe Offenlandlebensräume. Auf diese Weise entstanden die typischen europäischen Kulturlandschaften mit ihren charakteristischen, diversen Artengemeinschaften. Extensiv bewirtschaftete Flächen, auf denen etwa Weidewirtschaft betrieben wurde, haben jedoch im Zuge der landwirtschaftlichen Intensivierung während des 20. Jahrhunderts stark abgenommen. Gleichzeitig wurden landwirtschaftlich geeignete Böden in großem Umfang, insbesondere durch mineralische Düngung, aufgewertet. Eine Folge sind weitverbreitete Verluste von Pflanzendiversität, da mit zunehmender Nährstoffverfügbarkeit konkurrenzschwache Pflanzenarten vermehrt durch Arten verdrängt werden, die erfolgreich um Licht konkurrieren können. In Offenlandlebensräumen, in denen der Bodennährstoffgehalt nicht anthropogen erhöht ist, ist wenig darüber bekannt, wie Muster in Vegetationsgesellschaften mit bodenchemischen Faktoren zusammenhängen.

Wenn keine traditionelle landwirtschaftliche Bewirtschaftung stattfindet, erfordert der Erhalt von Offenlandlebensräumen ein Naturschutzmanagement, das Biomasse entnimmt, um sekundärer Sukzession und damit verbundenen Veränderungen in Pflanzengesellschaften entgegenzuwirken. In vielen Fällen hat sich extensive Beweidung mit großen domestizierten Pflanzenfressern als eine geeignete Maßnahme zum Erhalt von naturnahen Offenlandlebensräumen erwiesen. Unter bestimmten Bedingungen (z.B. große, unzugängliche Gebiete) ist Nutztierbeweidung allerdings nicht umsetzbar. Daher besteht Forschungsbedarf in Bezug auf die Frage, ob wilde Pflanzenfresser, welche weder ein eingezäuntes Gebiet noch regelmäßige (veterinärmedizinische) Betreuung benötigen, eine alternative Möglichkeit zur Beweidung im Naturschutz sein könnten.

Mit dem Truppenübungsplatz Grafenwöhr in Bayern stand für die vorliegende Arbeit ein Studiengebiet zur Verfügung, in dem wegen der mehr als hundertjährigen militärischen Nutzung keine landwirtschaftliche Intensivierung stattgefunden hat. Die zahlreich vorkommenden wildlebenden Rothirsche (Cervus elaphus) nutzen in diesem Gebiet das Offenland, z.B. naturnahes Grünland und Heiden, zur Nahrungssuche. Mit Fokus auf zwei exemplarische Natura 2000-Offenlandlebensraumtypen (Trockene Europäische Heiden und Magere Flachlandmähwiesen) untersucht diese Dissertation (i) die Beziehung zwischen bodenchemischen Faktoren und Vegetationsmustern unter nahezu vorindustriellen Bodenbedingungen und (ii) das Zusammenspiel von Beweidung freilebender Rothirsche und verschiedenen Vegetationsprozessen.

Kapitel 1 beleuchtet, wie die natürlich vorkommende Variabilität von Phosphor und anderen bodenchemischen Faktoren mit der Komposition und dem Artenreichtum von Vegetationsgesellschaften in Offenlandlebensräumen zusammenhängt. Im Jahr 2014 wurden Vegetationsaufnahmen von 40 bzw. 54 Relevés in Heiden und Grünland durchgeführt. Die Erkenntnisse liefern wertvolle Informationen über die Sensitivität unterschiedlicher naturnaher Lebensräume gegenüber Veränderungen in bodenchemischen Faktoren. Der Pflanzenartenreichtum nahm mit steigendem 
Boden-pH in Heiden zu und im Grünland mit steigender Phosphorkonzentration im Boden ab. Daher sollte das Naturschutzmanagement darauf achten, weitere Versauerung in Heiden sowie selbst geringfügige Phosphorzufuhr im Grünland zu verhindern.

Kapitel 2 \& 3 untersuchen den Beitrag freilebender Rothirsche zur Erhaltung von naturnahem Grünland und Heiden basierend auf einem Beweidungsausschlussexperiment, welches von 2015 bis 2017/18 auf einem Teil der im Jahr 2014 für die Vegetationsaufnahmen genutzten Untersuchungsflächen durchgeführt wurde. Um Synergieeffekte zwischen Wildtierbeweidung und zusätzlicher Biomasseentnahme (Brand, Mahd) ermitteln zu können, umfasste das Experiment im Grünland gebrannte, gemähte sowie unbehandelte Behandlungsflächen.

Kapitel 2 analysiert die Dynamik von Produktivität und Nahrungsqualität der Vegetation und Biomasseentnahme durch Rothirsche. Dazu wurden versetzbare Weidekörbe eingesetzt, welche auf offen zugänglichen, kontinuierlich beweideten Plots installiert und fünf Mal pro Vegetationsperiode umgesetzt wurden. Die jährlich von wilden Rothirschen aufgenommene Biomasse lag in einer vergleichbaren Größenordnung wie die Futteraufnahme domestizierter Weidetiere bei in Naturschutzbeweidungssystemen üblichen Besatzdichten. Trotz unterschiedlicher Produktivität und Beweidungsansprüche von naturnahem Grünland und Heiden erwies sich die Biomasseentnahme durch Rothirsche mit ihrer habitatspezifischen saisonalen Variation als günstig für beide Lebensraumtypen. Die Mahd, einhergehend mit erhöhter Produktivität und Nahrungsqualität in der späteren Jahreszeit, erhöhte die Attraktivität des Grünlands für die Rothirsche und könnte daher eine Strategie sein, um die Beweidung von freilebenden Rothirschen räumlich steuern zu können.

Basierend auf dem Vergleich der Vegetationsentwicklung in offenen und permanent eingezäunten Plots untersucht Kapitel 3, wie Pflanzendiversität und Vegetationsstruktur auf den Ausschluss von Rothirschen reagieren. Die Vegetationszusammensetzung in offenen und permanent eingezäunten Plots entwickelte sich in beiden Lebensraumtypen unterschiedlich. Im Grünland war die Pflanzendiversität in eingezäunten Plots signifikant niedriger als in offenen Plots. Als Anzeichen für beginnende Sukzession unter Rothirschausschluss wurden in beiden Lebensräumen eine zunehmende Höhe von Vegetation und Streuschicht sowie in Heiden abnehmende Deckung von Offenboden und zunehmende Individuenzahl verholzender Pflanzen festgestellt. Im Grünland zeigten sich in der gemähten Behandlungsfläche die deutlichsten Unterschiede zwischen offenen und eingezäunten Plots, was darauf hindeutet, dass Rothirschbeweidung kombiniert mit Mähen besonders günstige Verhältnisse für Pflanzendiversität im Grünland schaffen könnte.

Die Ergebnisse von Kapitel 2 \& 3 legen nahe, dass Beweidung durch wildlebende Rothirsche für das Naturschutzmanagement naturnaher Offenlandlebensräume von Nutzen sein könnte, nicht nur quantitativ - in Form von Biomasseentzug - sondern auch qualitativ, durch vorteilhafte Auswirkungen auf Vegetationsstruktur und -diversität. Ein angepasstes Wildtiermanagement, das Rothirschen erlaubt, sich ihre Nahrung im Offenland zu suchen, könnte daher zur Erhaltung von naturnahen Offenlandlebenstäumen beitragen und zugleich das Konfliktpotential zwischen Rothirsch und Forstwirtschaft mindern. Wildlebende Rothirsche in das Naturschutz- 
management zu integrieren, erscheint besonders vielversprechend und praktikabel in großen Gebieten, wie etwa Kernzonen von Nationalparks, Wildnisgebieten oder aktiven und ehemaligen Truppenübungsplätzen.

Insgesamt können die Erkenntnisse aus dieser Arbeit dazu beitragen, geeignete Strategien für das Naturschutzmanagement naturnaher Offenlandlebensräume zu entwickeln, um ihre Biodiversität und Ökosystemdienstleistungen in Zeiten zu erhalten, in denen Ökosysteme durch menschlichen Einfluss zunehmend gefährdet sind. 


\section{PART I}

\section{General Introduction}

The preservation of semi-natural open habitats in the face of ongoing agricultural intensification and abandonment is among the key challenges to nature conservation in Europe. Socio-economic or other constraints can impede the implementation of conventional management measures, such as livestock grazing, particularly in large conservation areas. It is hence urgently required to develop alternative management strategies for maintaining semi-natural open habitats. Whether grazing by autochthonous wild herbivores could contribute to the conservation management of open habitats has not been tested so far in a Central European context. This thesis presents insights from an experimental case study in a military training area in Germany, where semi-natural grasslands and heathlands have been grazed by freeranging red deer (Cervus elaphus) for many decades. The following paragraphs will introduce the background of the study relating to semi-natural habitats, large herbivores and their relevance to conservation. Subsequently, Part II of this work will present three original research articles as published in or submitted to international journals. 


\section{The origin of semi-natural open habitats}

The global environmental impacts of human land use today are mostly disastrous (Foley et al. 2005; Rockström et al. 2009) and contribute to a rapid loss of species comparable with a sixth mass extinction wave (Barnosky et al. 2011; Pimm et al. 2014; Ceballos et al. 2015; Ceballos et al. 2017). However, particular forms of human land use in former times have created and maintained many habitats of high biodiversity. For example, the present European 'cultural landscapes' (Farina 2000; Plieninger et al. 2013; Tieskens et al. 2017) have been shaped over the past millennia by human activities (Bignal and McCracken 2000).

Hunters and gatherers, present in Europe since the last glaciation, contributed to ecological processes through predation, consumption of vegetation, distribution of seeds and disturbances (Bignal and McCracken 2000). When people started to settle and cultivate the land, the human impact on the landscape became more profound. Dense forest had to make way for open space, which was used as arable land or pasture. This was accompanied by an increase in the abundance and distribution of light-demanding species, which were previously mostly limited to areas where abiotic conditions impeded tree growth (Hejcman et al. 2013). As a consequence, the biological diversity at both the species and habitat scale increased (Bignal and McCracken 2000).

Specific forms of human exploitation promoted different open habitats, such as grasslands and heathlands, which are now termed 'semi-natural' because their vegetation has not been planted by humans but is influenced by human actions (FAO 2000).

For example, the oldest archaeological record of scythes suggests that hay meadow communities probably evolved around the $7^{\text {th }}$ century BC (Hejcman et al. 2013). But only when livestock production became more intensive in Central Europe from the $18^{\text {th }}$ century onwards, the proportion of hay meadows increased, because the livestock that was more and more kept indoors required conserved forage. The increasing area of mown grasslands facilitated the spread of species characteristic to Central European lowland meadows today. The most prominent case is probably Arrbenatherum elatius (Hejcman et al. 2013), which is the eponymous species of the order Arrhenatheretalia, the agricultural grasslands in plant-sociological terminology (Leuschner and Ellenberg 2017).

Another habitat promoted by certain forms of human exploitation are heathlands, which developed across large areas in Europe about 4000 years ago (Webb 1998). Heathlands replaced forests after clearing when the land was subsequently used for livestock grazing and, additionally, turf and vegetation were cut for use as fuel and fodder for stabled animals. As the manure accumulating in the stables was used to fertilize arable fields, heathland soils were successively depleted of nutrients, which contributed to arresting the succession to scrub and forest (Webb 1998).

\section{The conservation value of semi-natural open habitats}

Open landscapes such as semi-natural grasslands and heathlands are of immense importance for conservation. At global as well as local scale, they are hotspots of 
plant and animal biodiversity supporting many threatened species (Vickery et al. 2001; Price 2003; Wilson et al. 2012; Dengler et al. 2014; Berry et al. 2016). For example, a maximum of 116 plant species on an area of $25 \mathrm{~m}^{2}$ has been reported for semi-dry basiphilous grasslands in the Czech Republic (Wilson et al. 2012). In addition, these ecosystems provide various regulating and provisioning services, such as soil conservation and pollination (Sala and Paruelo 1997; Harrison et al. 2010; Wrage et al. 2011; Burkhard et al. 2012; Maes et al. 2015; Holland et al. 2017). The aforementioned examples of hay meadows and heathlands show that semi-natural open habitats furthermore represent a cultural heritage of human civilisation (Webb 1998; Farina 2000; Hejcman et al. 2013; Tieskens et al. 2017). These landscapes appeal to most people's aesthetic perception, which in turn represents another facet of the cultural ecosystem services delivered by semi-natural open habitats (Plieninger et al. 2013; Tieskens et al. 2017; Assandri et al. 2018).

However, the area covered by extensively used open landscapes, e.g. land used for pastoral grazing, has declined tremendously in Europe during the last century (Webb 1998; Bignal and McCracken 2000; Poschlod and WallisDeVries 2002; Pywell et al. 2011; Hooftman and Bullock 2012). On the one hand, this still proceeding development is driven by agricultural intensification; on the other hand, by the abandonment of marginal sites that have become unprofitable for farming (Bignal and McCracken 2000; Hodgson et al. 2005; Poschlod et al. 2009; Hilpold et al. 2018). The relative importance of these main drivers of the loss of traditional agricultural practices and the associated decline of extensively used open habitats differs between European countries and regions due to their heterogeneous socio-political and economic history (Jepsen et al. 2015). Today, semi-natural grasslands and heathlands in most European countries cover less than $10 \%$ of their former areal extent (Piessens et al. 2004; Fagúndez 2012; Berry et al. 2016) and continue to decline (European Environment Agency 2015a; Berry et al. 2016).

The European Union has acknowledged the value of semi-natural open habitats and the necessity of their conservation by listing many of them in Annex I of the EU Habitats Directive (Council Directive 92/43/EEC on the Conservation of natural habitats and of wild fauna and flora). The EU member states are obliged to establish conservation measures for theses habitat types and must ensure management in accordance with their ecological requirements. However, only a small fraction of open habitats protected under the Habitats Directive (12.3\% of grasslands, $26.2 \%$ of heathlands) is actually in a favourable conservation status (European Environment Agency 2015b). There is hence an urgent need for applied conservation research to identify and develop adequate and feasible approaches for the maintenance of different semi-natural open habitat types.

\section{The current situation of semi-natural grasslands and heathlands}

A resurvey study on historical grassland relevés from the 1950/60s in northern Germany has provided evidence that up to $50 \%$ of plant species at the plot-level have been lost from grasslands since the middle of the $20^{\text {th }}$ century, as a consequence of intensified management and increased nutrient input (Wesche et al. 2012). The loss of biodiversity in grasslands is not limited to plants, as land use intensification 
has in fact homogenised grassland species communities across all trophic levels (Gossner et al. 2016).

Vascular plant species richness per se is low in heathlands (Fagúndez 2012), but they provide a valuable habitat for rare plant species (Kleijn et al. 2008) as well as rich animal (Usher 1992; Usher and Thompson 1993; Hartley et al. 2003; Littlewood et al. 2006; Buchholz et al. 2013) and cryptogam communities (Chytrý et al. 2001). Apart from habitat loss, conservation concerns are related to gradual shifts in heathland plant species composition towards grass- (Bakker and Berendse 1999) or treedominated communities (Kepfer-Rojas et al. 2015) and the rapid decline of rare herbaceous heathland species sensitive to changes in soil biochemistry (Houdijk et al. 1993; Kleijn et al. 2008).

The present thesis is focused on two open habitat types protected within the framework of the EU Habitats Directive: (i) lowland hay meadows (habitat type 6510)_defined as species-rich grasslands with abundant flowers mown only once or twice per year on little to moderately fertilised soils of the plain to submontane levels belonging to the Arrhenatherion and the Brachypodio-Centaureion nemoralis alliances and (ii) European dry heaths (habitat type 4030)—characterized as mesophile or xerophile shrub communities dominated by Ericoideae species on siliceous, podsolic soils in moist Atlantic and sub-Atlantic climates of plains and low mountains of Western, Central and Northern Europe (European Commission 2013). Similarly to many other Annex I habitat types, both are classified as being dependent on agricultural activities (Halada et al. 2011).

According to the results of the Habitats Directive - Article 17 reporting process in the EU 27 for the period 2007-2012, the overall assessment as well as the future prospects of both habitat types are 'unfavourable-bad' in the majority of European biogeographic regions. In the continental climate region in Germany, the dominant threats and pressures reported for lowland hay meadows relate to the intensification of agricultural practices, including mowing, grazing and fertilisation and the conversion to arable land. European dry heaths in this region suffer mainly from the abandonment of pastoral systems and lack of grazing, succession and change in species composition. The two focal habitat types of the present study can hence be considered as representatives for the majority of semi-natural open habitat types whose future maintenance in Europe is critically endangered without effective conservation management approaches.

\section{Large herbivores in the conservation management of open habitats}

Against the backdrop of today's lack of traditional extensive land use practices in Europe, conservation management is required to attend to biomass removal in seminatural open habitats in order to prevent secondary succession and undesirable changes in plant communities (MacDougall and Turkington 2007; Tälle et al. 2016; Valkó et al. 2018). Over the past few decades, besides mechanical management (e.g. mowing or burning), extensive grazing with different livestock species has increasingly been implemented in open and semi-open areas of high conservation interest (Van Wieren 1995; Bunzel-Drüke et al. 2008; Rosenthal et al. 2012; García et 
al. 2013; Bunzel-Drüke et al. 2015). It has been appreciated that large mammalian herbivores can contribute to structural heterogeneity and biodiversity (Olff and Ritchie 1998; Adler et al. 2001). Whether the actual grazing impact on plant diversity in a certain system is positive or negative, might however depend on habitat productivity and herbivore species (Bakker et al. 2006). Positive effects of large herbivores on plant species richness and diversity generally occur when grazing induces changes in the competitive environment reducing the abundance of dominant species (Koerner et al. 2018) and alleviating light competition (Borer et al., 2014).

In contrast to livestock grazing, the potential contribution of autochthonous wild herbivores to maintaining open habitat vegetation has only recently found the attention of applied conservation science (Tschöpe et al. 2011; Schulze et al. 2018). This might be related to certain controversial questions in conservation theory concerning the relevance of wild herbivores for vegetation development in historic times, e.g.: Which vegetation types would be 'naturally' prevailing in Europe (Vera 2000; Svenning 2002; Sutherland 2002; Mitchell 2005; Leuschner and Ellenberg 2017)? Which historic time period is suitable to serve as a reference for defining 'natural' vegetation (Johnson 2009)? How much did humans contribute to megafauna extinctions at the end of the Pleistocene (Barnosky 2008; Sandom, et al. 2014; Svenning et al. 2016)?

Independently from specific answers to these background questions, however, the influence of wild herbivores on the ecology and evolution of vegetation worldwide has now been widely recognized (Sandom et al. 2014; Bakker et al. 2016; Pausas and Bond 2018). Simultaneously, rewilding (Fuhlendorf et al. 2009; Ceaușu et al. 2015; Svenning et al. 2016) and wilderness protection (Schumacher et al. 2018) have become popular concepts in conservation. The basic idea is that conservation management based on wild instead of domestic herbivores could allow for more natural grazing regimes and ecological dynamics (Sutherland 2002; Ceaușu et al. 2015).

\section{Red deer-candidates for wildlife conservation grazing?}

In contemporary Europe, red deer are one of the largest and most widespread native mammal species (Milner et al. 2006; Zachos and Hartl 2011). At the evolutionary timescale, cervids persisted in highly variable habitats ranging from open, grassy environments to intermediate savannahs and temperate wooded habitats (Lister 1984; Lister 2004). During the drastic changes in climate and environmental conditions in Late Glacial and early Holocene time, red deer even preferred open environments, but today, the species is mostly associated with forested environments (Drucker et al. 2011). Consequently, it has been repeatedly noted that browse constitutes the main food component for red deer (Gebert and Verheyden-Tixier 2001; Katona et al. 2014), but see Schröder 1977). This observation, however, might result from the limited habitat choice of red deer in the European cultural landscape due to human disturbance (e.g. from hunting or recreation) and habitat fragmentation (Lister 1984; Jayakody et al. 2011; Meiri et al. 2013). Based on 
morphophysiological characteristics, red deer are classified as ruminants of the intermediate feeding type (Hofmann 1989): their nutritional physiology is in-between highly selective 'concentrate selectors', such as roe deer (Capreolus capreolus), adapted to a high-quality diet, and generalist 'grass and roughage eaters', such as cattle (Bos taurus domesticus), adapted to forage with high fibre concentration. They forage opportunistically, i.e. switch between browsing and grazing, dependent on seasonal fluctuations of forage quantity and quality as well as metabolism-related nutrient requirements (Hofmann 1989).

The ability of red deer to forage more selectively and to choose from a wider spectrum of forage types than most domestic large herbivores, which are predominantly grass and roughage eaters, could potentially result in different impacts of red deer on vegetation compared to livestock. A further key aspect regarding the relationship between red deer and vegetation is that the habitat use of the wild animals is not restricted by fences or herding. While stocking rates of domestic herbivores in livestock grazing systems can be adjusted as needed for specific conservation purposes, the population density of wild red deer is not closely related with their foraging impact, since they are able to freely choose between differently preferred vegetation types (Gordon et al. 2004; Moore et al. 2015). On the one hand, this poses the question how to spatially direct grazing activities of free-ranging red deer in order to harmonise red deer habitat use with the grazing requirements of different habitat types (Moore et al. 2015). On the other hand, the fact that wild herbivores, in contrast to livestock, do not require fencing, regular monitoring or veterinary treatment could facilitate the implementation of conservation grazing under certain conditions. Particularly in very large, remote or inaccessible areas, such as military training areas, where conventional conservation measures are economically or practically unfeasible, grazing by wild red deer could be an appealing opportunity for conservation management.

\section{Military training areas-opportunities for science and conservation}

Up to $80 \%$ of the land area in Europe is used for production systems (agriculture and forestry), settlement and infrastructure (European Environment Agency 2008). Areas with high yield potential are almost always used for intensive agriculture (Hodgson et al. 2005). Plant diversity and its determinants, such as soil chemical factors, have been studied extensively in such agricultural systems where nutrient availability is chronically enhanced. For instance, it is well-known that species richness responds negatively to additions of nitrogen or phosphorus (Ceulemans et al. 2013; Field et al. 2014; Tang et al. 2017), which favour competitive species, enhance light competition and finally result in the exclusion of small and slow-growing species (Hautier et al. 2009). By contrast, open habitats that have not been agriculturally meliorated at any time in the past (e.g. by mineral fertilisation) are rare. Hence, knowledge on the drivers of phytodiversity under zero-input conditions is scarce.

Military training areas (MTAs) differ from the surrounding landscape because military land use precludes intensive agriculture, and open habitats are maintained for training purposes. In terms of soil chemical factors, MTAs are therefore often comparatively pristine systems, where the soil nutrient status is still comparable with 
pre-industrialised levels. Besides, MTAs have been recognized for their nature conservation value (Warren et al. 2007; Lindenmayer et al. 2016; Ellwanger and Reiter 2019), in particular regarding plants and butterflies (Cizek et al. 2013), grasshoppers and ground beetles (Warren and Büttner 2008a), dragonflies (Harabiš and Dolný 2018), amphibians (Warren and Büttner 2008b) and birds (Bušek and Reif 2017). It is supposed that biodiversity does not only benefit from the lack of intensive cultivation on MTAs, but also from the heterogeneous disturbance regime caused by military training and vehicle traffic (Warren et al. 2007). With regard to the usually large size of MTAs and the limited accessibility to unauthorized persons, promoting grazing by wild herbivores could potentially be an advantageous strategy to enhance and preserve the high conservation value of these areas.

\section{Study area}

In our study, we took advantage of such a site unaffected by industrialised agricultural practices: the Grafenwöhr military training area (GTA) in the Upper Palatinate (German: Oberpfalz), in north-eastern Bavaria, Germany (Fig. 1). The site has served military training purposes for more than one century. The older part (almost $100 \mathrm{~km}^{2}$ ) of the present area was acquired by the Bavarian Military administration between 1907 and 1909. A further $140 \mathrm{~km}^{2}$ were added to the western part of the area in 1938/39. Ordinary agricultural land use had accordingly stopped in GTA long before the agricultural intensification gained substantial momentum in the middle of the $20^{\text {th }}$ century (Wesche et al. 2012).

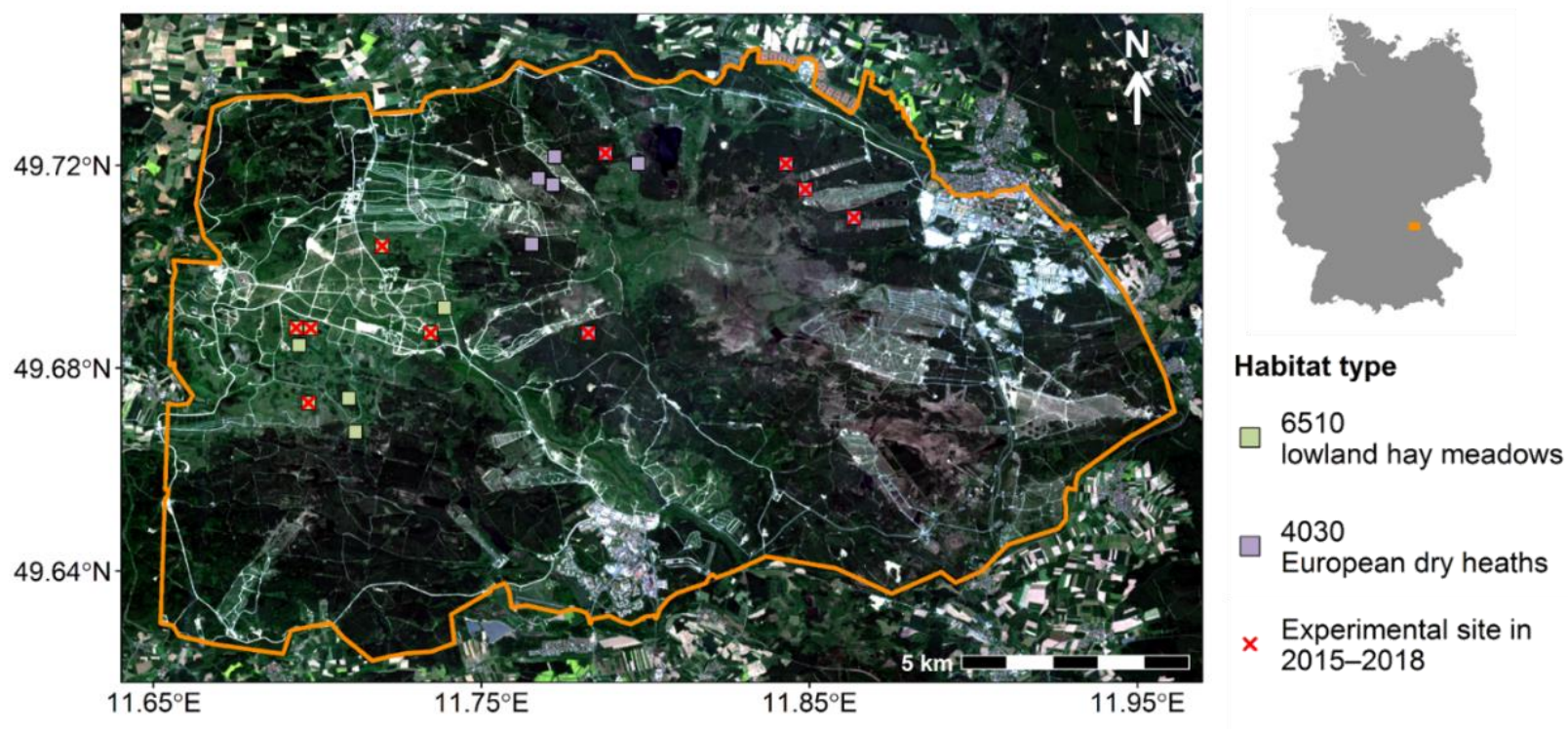

Figure 1: Study area Grafenwöhr military training area located in Bavaria, Germany. In 2014, vegetation relevés were taken on nine sampling sites in grasslands (habitat type 6510, lowland hay meadows) and 10 sampling sites heathlands (habitat type European dry heaths). Five of these sampling sites, respectively, were used in the experimental study of vegetation dynamics and impacts of grazing by wild red deer. The background map is based on modified Copernicus Sentinel-2 data (acquisition date: 22 May 2016; C. Raab). 
Today, GTA is covered for the larger part by woodlands, but approximately $40 \%$ of the area consist of heterogeneous open and semi-open habitats (C. Raab, unpublished). Situated amidst an intensively cultivated landscape, GTA thus offers the opportunity to study plant community patterns in semi-natural open habitats and their relationship to endogenous soil chemical factors in the absence of direct anthropogenic enhancement of nutrient availability.

Apart from the virtually pre-industrialized soil nutrient status, the second peculiarity of GTA is the large resident population of wild and free-ranging red deer. Several decades ago, the German Federal Forests Division (Bundesforst), in charge of the land and hunting management in GTA, has introduced a progressive wildlife management regime with the aim to reduce browsing damage in the commercially used forests. The underlying idea is to redirect red deer from the forests to the open landscapes based on a push-and-pull strategy: red deer are hunted intensively in forests, whereas they are spared from hunting in open areas for most the year, so that the animals are free to use the open landscapes for foraging (Meißner et al. 2013). Therefore, in GTA, it is possible to evaluate the effects of a wild large herbivore on the vegetation of different semi-natural open habitat types.

\section{Experimental design}

In 2014, nine and 10 sampling sites, respectively, were selected within the habitat types lowland hay meadows (hereafter 'grasslands') and European dry heaths ('heathlands') in GTA (Fig. 1). The plant species composition was surveyed in six relevés per site in grasslands and four relevés per site in heathlands. To study the relationships between red deer grazing and vegetation productivity and biomass dynamics, forage quality, and plant species composition and diversity, in 2015, a grazing experiment was established on five of these sampling sites per habitat type. The general experimental set up in grasslands (Fig. 2) included three treatment areas (B, burnt, $\mathrm{M}$, mown and $\mathrm{U}$, untreated). Per treatment, a pair of plots was demarcated: an open plot, continuously accessible to all kinds of animals, and a fenced plot that permanently excluded red deer and other larger animals. Each plot contained one vegetation relevé. Additionally, on the open plots, a temporary, movable exclusion cage was installed, in order to determine the aboveground net primary productivity of the grazed vegetation and forage removal by red deer (McNaughton et al. 1996).

As opposed to grasslands, the experimental design implemented in heathlands was not orthogonal. At the outset of the experiment, it was already clear that implementing the M treatment was impossible in heathlands, as these areas in GTA are highly contaminated by remnants of ammunition and unexploded ordnance, impeding the use of agricultural machinery. By contrast, the B treatment was initially included in the heathland study design, in the form of a one-time burning event in the first study year. Owing to low standing biomass and unfavourable weather conditions, however, the $\mathrm{B}$ treatment failed on three out of the five heathland 


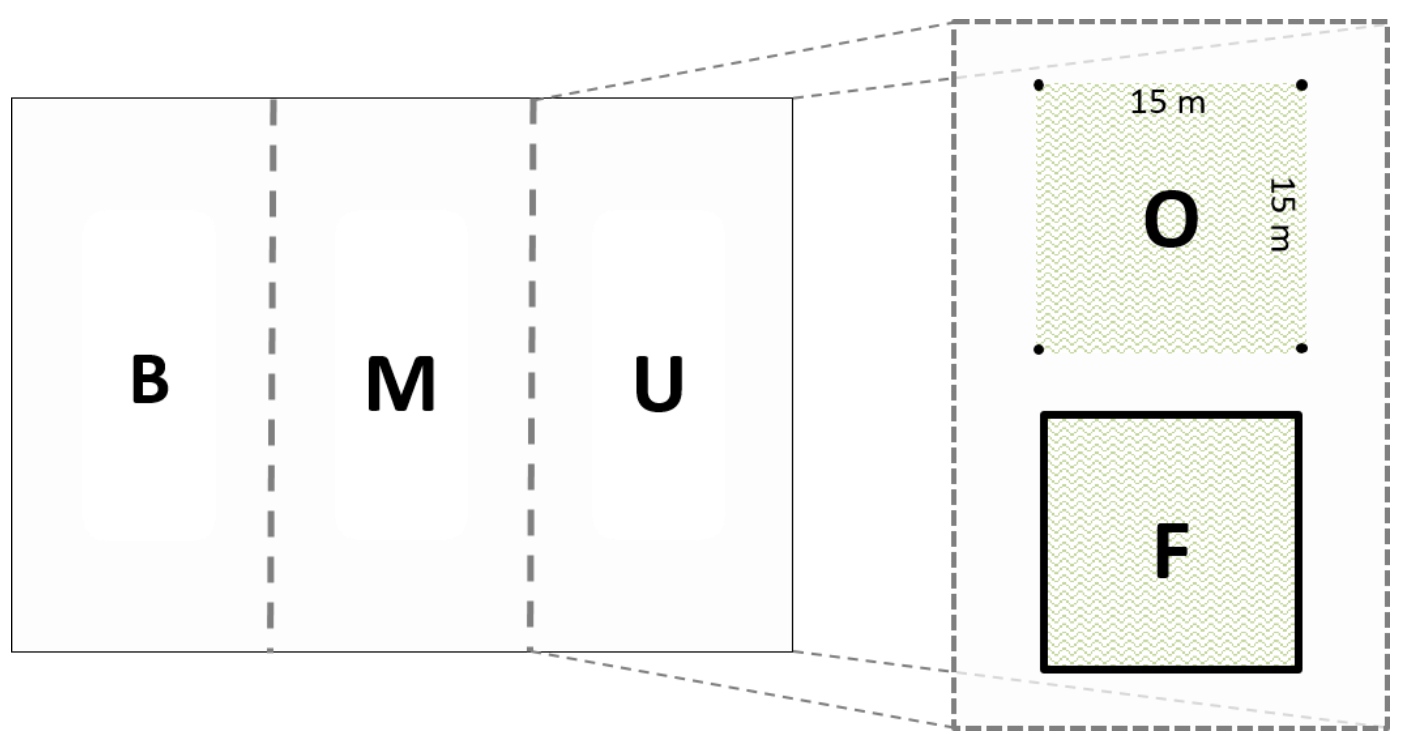

Figure 2: Conceptual representation of the study design implemented in grasslands. Each sampling site consisted of three treatment areas, which were either annually burnt (B) or mown (M) or remained untreated $(\mathrm{U})$. Each treatment area contained a pair of sampling plots. The open plot $(\mathrm{O})$ was continuously accessible to wild red deer, while the fenced plot (F) was protected from grazing throughout the three experimental years. Sampling sites in heathlands were composed of the $\mathrm{U}$ treatment with one or two pairs of plots.

sampling sites. Accordingly, in heathlands, only the $U$ treatment was assessed, on two sites with one and three sites with two pairs of plots. The data collection in the experiment ran from April 2015 until April 2018. To investigate the response of plant species composition and diversity to the experimental conditions, the vegetation relevés were resurveyed in summer 2018.

\section{Research objectives and chapter outline}

The present work took advantage of the experimental study design in GTA to expand our knowledge on (i) the relationship between soil chemical parameters and vegetation patterns in semi-natural open habitats not altered by anthropogenic fertilizer input, and (ii) the interplay of grazing by free-ranging red deer and different vegetation processes. The overarching goal of this thesis is to contribute to the development of effective and expedient strategies for the conservation of seminatural open habitats in order to preserve their biodiversity and ecosystem services in times of increasing anthropogenic pressure on ecosystems (European Environment Agency 2015c; Jones et al. 2018).

In three chapters, this thesis addresses the following research issues:

In the face of the widely enhanced soil nutrient status today, especially in terms of phosphorus, Chapter 1 focuses on the question how gradients in phosphorus and other soil chemical parameters that naturally occur in unimproved open habitats relate to plant species community composition and richness. The results allow for the identification of the soil chemical parameters with the most decisive influence on plant communities in semi-natural grasslands and heathlands, respectively. These 
findings are used to give habitat-type specific recommendations for conservation management in order to prevent future deterioration of habitat quality related to human-induced changes in soil chemical parameters.

Chapter 2 shifts the focus to the dynamics of vegetation productivity, forage quality and forage removal by red deer, which were assessed over three years. Whether grazing by free-ranging red deer is compatible with the grazing requirements of different semi-natural open habitats is evaluated based on detailed information on annual and seasonal biomass productivity and removal by red deer. Forage quality data are linked to forage removal by red deer in order to reveal potential synergistic effects between wildlife grazing and additional grassland management measures.

Chapter 3 investigates how plant species richness, diversity, community composition and vegetation structure in grasslands and heathlands respond to the experimental exclusion of wild and free-ranging red deer. The vegetation development is compared between open and fenced plots to evaluate whether grazing by wild red deer contributes to the preservation of the characteristic plant communities in different semi-natural open habitats. Reduced plant diversity in grasslands following red deer exclusion and different indications of beginning succession in fenced plots in both habitat types substantiate the suitability of grazing by wild red deer as an alternative conservation management approach.

Finally, this thesis concludes with a General Discussion of the key findings, putting the merits and limitations of grazing by wild red deer into a broader conservation context. A special attempt will be made to assess the transferability of grazing by red deer as practised in GTA to other areas with open habitats of conservation interest. 


\section{References}

Adler P, Raff D, Lauenroth W. 2001. The effect of grazing on the spatial heterogeneity of vegetation. Oecologia 128:465-479.

Assandri G, Bogliani G, Pedrini P, Brambilla M. 2018. Beautiful agricultural landscapes promote cultural ecosystem services and biodiversity conservation. Agriculture, Ecosystems \& Environment 256:200-210.

Bakker ES, Gill JL, Johnson CN, Vera FWM, Sandom CJ, Asner GP, Svenning J-C. 2016. Combining paleo-data and modern exclosure experiments to assess the impact of megafauna extinctions on woody vegetation. Proceedings of the National Academy of Sciences 113:847-855.

Bakker ES, Ritchie ME, Olff H, Milchunas DG, Knops JMH. 2006. Herbivore impact on grassland plant diversity depends on habitat productivity and herbivore size. Ecology Letters 9:780_ 788.

Bakker JP, Berendse F. 1999. Constraints in the restoration of ecological diversity in grassland and heathland communities. Trends in Ecology \& Evolution 14:63-68.

Barnosky AD. 2008. Megafauna biomass tradeoff as a driver of Quaternary and future extinctions. Proceedings of the National Academy of Sciences 105:11543-11548.

Barnosky AD, Matzke N, Tomiya S, Wogan GOU, Swartz B, Quental TB, Marshall C, McGuire JL, Lindsey EL, Maguire KC, et al. 2011. Has the Earth's sixth mass extinction already arrived? Nature 471:51-57.

Berry P, Smith A, Eales R, Papadopoulou L, Erhard M, Meiner A, Bastrup-Birk A, Ivits E, Gelabert ER, Dige G. 2016. Mapping and assessing the condition of Europe's ecosystems: progress and challenges - EEA contribution to the implementation of the EU Biodiversity Strategy to 2020. Luxembourg, LU: European Environment Agency.

Bignal EM, McCracken DI. 2000. The nature conservation value of European traditional farming systems. Environmental Reviews 8:149-171.

Buchholz S, Hannig K, Schirmel J. 2013. Losing uniqueness - shifts in carabid species composition during dry grassland and heathland succession. Animal Conservation 16:661-670.

Bunzel-Drüke M, Böhm C, Finck P, Kämmer G, Luick R, Reisinger E, Riecken U, Riedl J, Scharf M, Zimball O. 2008. "Wilde Weiden”: Praxisleitfaden für Ganzjahresbeweidung in Naturschutz und Landschaftsentwicklung. Bad Sassendorf-Lohne, DE: Arbeitsgem. Biologischer Umweltschutz im Kreis Soest eV (ABU).

Bunzel-Drüke M, Böhm C, Finck P, Kämmer G, Luick R, Reisinger E, Riecken U, Riedl J, Scharf M, Zimball O. 2015. Naturnahe Beweidung und NATURA 2000: Ganzjahresbeweidung im Management von Lebensraumtypen und Arten im europäischen Schutzgebietssystem NATURA 2000. Duderstadt, DE: Heinz-Sielmann-Stiftung.

Burkhard B, Kroll F, Nedkov S, Müller F. 2012. Mapping ecosystem service supply, demand and budgets. Ecological Indicators 21:17-29.

Bušek O, Reif J. 2017. The potential of military training areas for bird conservation in a central European landscape. Acta Oecologica 84:34-40.

Ceaușu S, Hofmann M, Navarro LM, Carver S, Verburg PH, Pereira HM. 2015. Mapping opportunities and challenges for rewilding in Europe. Conservation Biology 29:1017-1027.

Ceballos G, Ehrlich PR, Barnosky AD, García A, Pringle RM, Palmer TM. 2015. Accelerated modern human-induced species losses: Entering the sixth mass extinction. Science Advances 1:e1400253.

Ceballos G, Ehrlich PR, Dirzo R. 2017. Biological annihilation via the ongoing sixth mass extinction signaled by vertebrate population losses and declines. Proceedings of the National Academy of Sciences 114:E6089-E6096.

Ceulemans T, Merckx R, Hens M, Honnay O. 2013. Plant species loss from European semi-natural grasslands following nutrient enrichment - is it nitrogen or is it phosphorus? Global Ecology and Biogeography 22:73-82.

Chytrý M, Sedláková I, Tichý L. 2001. Species richness and species turnover in a successional heathland. Applied Vegetation Science 4:89-96.

Cizek O, Vrba P, Benes J, Hrazsky Z, Koptik J, Kucera T, Marhoul P, Zamecnik J, Konvicka M. 2013. Conservation potential of abandoned military areas matches that of established reserves: plants and butterflies in the Czech Republic. PloS one 8:e53124. 
Dengler J, Janišová M, Török P, Wellstein C. 2014. Biodiversity of Palaearctic grasslands: a synthesis. Agriculture, Ecosystems \& Environment 182:1-14.

Drucker DG, Bridault A, Cupillard C, Hujic A, Bocherens H. 2011. Evolution of habitat and environment of red deer (Cervus elaphus) during the Late-glacial and early Holocene in eastern France (French Jura and the western Alps) using multi-isotope analysis $\left(\delta^{13} \mathrm{C}, \delta^{15} \mathrm{~N}, \delta^{18} \mathrm{O}\right.$, $\delta^{34}$ S) of archaeological remains. Quaternary International 245:268-278.

Ellwanger G, Reiter K. 2019. Nature conservation on decommissioned military training areas German approaches and experiences. Journal for Nature Conservation 49:1-8.

European Commission. 2013. Interpretation Manual of European Union Habitats, version EUR 28 [Internet]. [cited 2019 Mar 2]. Available from: https://eunis.eea.europa.eu/references/2435

European Environment Agency. 2008. Land use - European Environment Agency [Internet]. [cited 2016 Dec 15]. Available from: http://www.eea.europa.eu/themes/landuse/intro

European Environment Agency. 2015a. EU 2010 biodiversity baseline — adapted to the MAES typology (2015). Luxembourg, LU: Publications Office of the European Union.

European Environment Agency. 2015b. Conservation status of species and habitats by ecosystem type from Habitats Directive Article 17 reporting [Internet]. [cited 2018 Aug 16]. Available from: https://www.eea.europa.eu/data-and-maps/daviz/conservation-status-of-species-and

European Environment Agency. 2015c. European environment-state and outlook 2015: assessment of global megatrends. Copenhagen, DK: European Environment Agency.

Fagúndez J. 2012. Heathlands confronting global change: drivers of biodiversity loss from past to future scenarios. Annals of Botany 111:151-172.

FAO. 2000. Land Cover Classification System [Internet]. [cited 2019 Feb 26]. Available from: http://www.fao.org/3/x0596e/x0596e01f.htm

Farina A. 2000. The Cultural Landscape as a Model for the Integration of Ecology and Economics. BioScience 50:313-320.

Field CD, Dise NB, Payne RJ, Britton AJ, Emmett BA, Helliwell RC, Hughes S, Jones L, Lees S, Leake JR, et al. 2014. The Role of Nitrogen Deposition in Widespread Plant Community Change Across Semi-natural Habitats. Ecosystems 17:864-877.

Foley JA, DeFries R, Asner GP, Barford C, Bonan G, Carpenter SR, Chapin FS, Coe MT, Daily GC, Gibbs HK. 2005. Global consequences of land use. Science 309:570-574.

Fuhlendorf SD, Engle DM, Kerby J, Hamilton R. 2009. Pyric Herbivory: Rewilding Landscapes through the Recoupling of Fire and Grazing. Conservation Biology 23:588-598.

García RR, Fraser MD, Celaya R, Ferreira LMM, García U, Osoro K. 2013. Grazing land management and biodiversity in the Atlantic European heathlands: a review. Agroforestry systems 87:19_ 43.

Gebert C, Verheyden-Tixier H. 2001. Variations of diet composition of red deer (Cervus elaphus L.) in Europe. Mammal Review 31:189-201.

Gordon IJ, Hester AJ, Festa-Bianchet M. 2004. REVIEW: The management of wild large herbivores to meet economic, conservation and environmental objectives. Journal of Applied Ecology 41:1021-1031.

Gossner MM, Lewinsohn TM, Kahl T, Grassein F, Boch S, Prati D, Birkhofer K, Renner SC, Sikorski J, Wubet T. 2016. Land-use intensification causes multitrophic homogenization of grassland communities. Nature 540:266.

Halada L, Evans D, Romão C, Petersen J-E. 2011. Which habitats of European importance depend on agricultural practices? Biodiversity and Conservation 20:2365-2378.

Harabiš F, Dolný A. 2018. Military training areas as refuges for threatened dragonfly species: Effect of spatial isolation and military activity. Biological Conservation 217:28-35.

Harrison PA, Vandewalle M, Sykes MT, Berry PM, Bugter R, Bello F de, Feld CK, Grandin U, Harrington R, Haslett JR, et al. 2010. Identifying and prioritising services in European terrestrial and freshwater ecosystems. Biodiversity and Conservation 19:2791-2821.

Hartley SE, Gardner SM, Mitchell RJ. 2003. Indirect effects of grazing and nutrient addition on the hemipteran community of heather moorlands. Journal of Applied Ecology 40:793-803.

Hautier Y, Niklaus PA, Hector A. 2009. Competition for Light Causes Plant Biodiversity Loss After Eutrophication. Science 324:636-638.

Hejcman M, Hejcmanová P, Pavlŭ V, Beneš J. 2013. Origin and history of grasslands in Central Europe-a review. Grass and Forage Science 68:345-363. 
Hilpold A, Seeber J, Fontana V, Niedrist G, Rief A, Steinwandter M, Tasser E, Tappeiner U. 2018. Decline of rare and specialist species across multiple taxonomic groups after grassland intensification and abandonment. Biodiversity and Conservation 27:3729-3744.

Hodgson JG, Grime JP, Wilson PJ, Thompson K, Band SR. 2005. The impacts of agricultural change (1963-2003) on the grassland flora of Central England: processes and prospects. Basic and Applied Ecology 6:107-118.

Hofmann RR. 1989. Evolutionary steps of ecophysiological adaptation and diversification of ruminants: a comparative view of their digestive system. Oecologia 78:443-457.

Holland JM, Douma JC, Crowley L, James L, Kor L, Stevenson DRW, Smith BM. 2017. Semi-natural habitats support biological control, pollination and soil conservation in Europe. A review. Agronomy for Sustainable Development 37:31.

Hooftman DAP, Bullock JM. 2012. Mapping to inform conservation: A case study of changes in semi-natural habitats and their connectivity over 70 years. Biological Conservation 145:3038.

Houdijk ALFM, Verbeek PJM, Dijk HFGV, Roelofs JGM. 1993. Distribution and decline of endangered herbaceous heathland species in relation to the chemical composition of the soil. Plant and Soil 148:137-143.

Jayakody S, Sibbald AM, Mayes RW, Hooper RJ, Gordon IJ, Lambin X. 2011. Effects of human disturbance on the diet composition of wild red deer. European Journal of Wildlife Research 57:939-948.

Jepsen MR, Kuemmerle T, Müller D, Erb K, Verburg PH, Haberl H, Vesterager JP, Andrič M, Antrop M, Austrheim G, others. 2015. Transitions in European land-management regimes between 1800 and 2010. Land Use Policy 49:53-64.

Johnson CN. 2009. Ecological consequences of Late Quaternary extinctions of megafauna. Proceedings of the Royal Society of London B: Biological Sciences:2509-2519.

Jones KR, Venter O, Fuller RA, Allan JR, Maxwell SL, Negret PJ, Watson JEM. 2018. One-third of global protected land is under intense human pressure. Science 360:788-791.

Katona K, Gál-Bélteki A, Terhes A, Bartucz K, Szemethy L. 2014. How important is supplementary feed in the winter diet of red deer? a test in Hungary. Wildlife Biology 20:326-334.

Kepfer-Rojas S, Verheyen K, Johannsen VK, Schmidt IK. 2015. Indirect effects of land-use legacies determine tree colonization patterns in abandoned heathland. Applied Vegetation Science 18:456-466.

Kleijn D, Bekker RM, Bobbink R, De Graaf MCC, Roelofs JGM. 2008. In search for key biogeochemical factors affecting plant species persistence in heathland and acidic grasslands: a comparison of common and rare species. Journal of Applied Ecology 45:680-687.

Koerner SE, Smith MD, Burkepile DE, Hanan NP, Avolio ML, Collins SL, Knapp AK, Lemoine NP, Forrestel EJ, Eby S, et al. 2018. Change in dominance determines herbivore effects on plant biodiversity. Nature Ecology \& Evolution 2:1925-1932.

Leuschner C, Ellenberg H. 2017. Ecology of Central European Non-forest Vegetation: Coastal to Alpine, Natural to Man-made Habitats. Cham, CH: Springer.

Lindenmayer DB, MacGregor C, Wood J, Westgate MJ, Ikin K, Foster C, Ford F, Zentelis R. 2016. Bombs, fire and biodiversity: Vertebrate fauna occurrence in areas subject to military training. Biological Conservation 204:276-283.

Lister AM. 1984. Evolutionary and ecological origins of British deer. Proceedings of the Royal Society of Edinburgh, Section B: Biological Sciences 82:205-229.

Lister AM. 2004. The impact of Quaternary Ice Ages on mammalian evolution. Philosophical Transactions of the Royal Society of London B: Biological Sciences 359:221-241.

Littlewood NA, Pakeman RJ, Woodin SJ. 2006. The response of plant and insect assemblages to the loss of Calluna vulgaris from upland vegetation. Biological Conservation 128:335-345.

MacDougall AS, Turkington R. 2007. Does the Type of Disturbance Matter When Restoring Disturbance-Dependent Grasslands? Restoration Ecology 15:263-272.

Maes J, Teller A, Erhard M, Liquete C, Braat L, Berry P, Egoh B, Puydarrieux P, Fiorina C, Santos F, others. 2015. Mapping and Assessment of Ecosystems and their Services: Trends in ecosystems and ecosystem services in the European Union between 2000 and 2010. Luxembourg, LU: European Commission Joint Research Centre. 
McNaughton SJ, Milchunas DG, Frank DA. 1996. How can net primary productivity be measured in grazing ecosystems? Ecology 77:974-977.

Meiri M, Lister AM, Higham TFG, Stewart JR, Straus LG, Obermaier H, Morales MRG, MarínArroyo AB, Barnes I. 2013. Late-glacial recolonization and phylogeography of European red deer (Cervus elaphus L.). Molecular Ecology 22:4711-4722.

Meißner M, Reinecke H, Herzog S. 2013. Vom Wald ins Offenland: Der Rothirsch auf dem Truppenübungsplatz Grafenwöhr. Raum-Zeit-Verhalten, Lebensraumnutzung, Management. 2nd ed. Kassel, DE: Frank Fornaçon.

Milner JM, Bonenfant C, Mysterud A, Gaillard J-M, Csányi S, Stenseth NC. 2006. Temporal and spatial development of red deer harvesting in Europe: biological and cultural factors. Journal of Applied Ecology 43:721-734.

Mitchell FJG. 2005. How open were European primeval forests? Hypothesis testing using palaeoecological data. Journal of Ecology 93:168-177.

Moore EK, Britton AJ, Iason G, Pemberton J, Pakeman RJ. 2015. Landscape-scale vegetation patterns influence small-scale grazing impacts. Biological Conservation 192:218-225.

Olff H, Ritchie ME. 1998. Effects of herbivores on grassland plant diversity. Trends in Ecology \& Evolution 13:261-265.

Pausas JG, Bond WJ. 2018. Humboldt and the reinvention of nature. Journal of Ecology:1-7.

Piessens K, Honnay O, Nackaerts K, Hermy M. 2004. Plant species richness and composition of heathland relics in north-western Belgium: evidence for a rescue-effect? Journal of Biogeography 31:1683-1692.

Pimm SL, Jenkins CN, Abell R, Brooks TM, Gittleman JL, Joppa LN, Raven PH, Roberts CM, Sexton JO. 2014. The biodiversity of species and their rates of extinction, distribution, and protection. Science 344:1246752.

Plieninger T, Dijks S, Oteros-Rozas E, Bieling C. 2013. Assessing, mapping, and quantifying cultural ecosystem services at community level. Land Use Policy 33:118-129.

Poschlod P, Baumann A, Karlik P. 2009. Origin and development of grasslands in Central Europe. In: Grasslands in Europe of High Nature Value. Zeist, NL: KNNV Publishing; p. 15-25.

Poschlod P, WallisDeVries MF. 2002. The historical and socioeconomic perspective of calcareous grasslands-lessons from the distant and recent past. Biological Conservation 104:361-376.

Price EAC. 2003. Lowland Grassland and Heathland Habitats. London, GB: Psychology Press.

Pywell RF, Meek WR, Webb NR, Putwain PD, Bullock JM. 2011. Long-term heathland restoration on former grassland: The results of a 17-year experiment. Biological Conservation 144:1602_ 1609.

Rockström J, Steffen W, Noone K, Persson A, Chapin F, Lambin E, Lenton T, Scheffer M, Folke C, Schellnhuber H, et al. 2009. Planetary Boundaries: Exploring the Safe Operating Space for Humanity. Ecology and Society 14:32.

Rosenthal G, Schrautzer J, Eichberg C. 2012. Low-intensity grazing with domestic herbivores : a tool for maintaining and restoring plant diversity in temperate Europe. Tuexenia 32:167-205.

Sala OE, Paruelo JM. 1997. Ecosystem services in grasslands. Nature’s services: Societal dependence on natural ecosystems:237-251.

Sandom C, Ejrnæs R, Hansen MDD, Svenning J-C. 2014. High herbivore density associated with vegetation diversity in interglacial ecosystems. Proceedings of the National Academy of Sciences 111:4162-4167.

Sandom C, Søren Faurby, Brody Sandel, Jens-Christian Svenning. 2014. Global late Quaternary megafauna extinctions linked to humans, not climate change. Proceedings of the Royal Society B: Biological Sciences 281:20133254.

Schröder W. 1977. Räumliche Verteilung und Nahrungsauswahl von Gams und Rotwild im Hochgebirge. Forstwissenschaftliches Centralblatt 96:94-99.

Schulze KA, Rosenthal G, Peringer A. 2018. Intermediate foraging large herbivores maintain semiopen habitats in wilderness landscape simulations. Ecological Modelling 379:10-21.

Schumacher H, Finck P, Riecken U, Klein M. 2018. More wilderness for Germany: Implementing an important objective of Germany's National Strategy on Biological Diversity. Journal for Nature Conservation 42:45-52.

Sutherland WJ. 2002. Conservation biology: Openness in management. Nature 418:834-835. 
Svenning J-C. 2002. A review of natural vegetation openness in north-western Europe. Biological Conservation 104:133-148.

Svenning J-C, Pedersen PBM, Donlan CJ, Ejrnæs R, Faurby S, Galetti M, Hansen DM, Sandel B, Sandom CJ, Terborgh JW, Vera FWM. 2016. Science for a wilder Anthropocene: Synthesis and future directions for trophic rewilding research. Proceedings of the National Academy of Sciences 113:898-906.

Tälle M, Deák B, Poschlod P, Valkó O, Westerberg L, Milberg P. 2016. Grazing vs. mowing: A metaanalysis of biodiversity benefits for grassland management. Agriculture, Ecosystems \& Environment 222:200-212.

Tang Z, Deng L, An H, Yan W, Shangguan Z. 2017. The effect of nitrogen addition on community structure and productivity in grasslands: A meta-analysis. Ecological Engineering 99:31-38.

Tieskens KF, Schulp CJ, Levers C, Lieskovskỳ J, Kuemmerle T, Plieninger T, Verburg PH. 2017. Characterizing European cultural landscapes: Accounting for structure, management intensity and value of agricultural and forest landscapes. Land Use Policy 62:29-39.

Tschöpe O, Wallschläger D, Burkart M, Tielbörger K. 2011. Managing open habitats by wild ungulate browsing and grazing: A case-study in North-Eastern Germany. Applied Vegetation Science 14:200-209.

Usher MB. 1992. Management and diversity of arthropods in Calluna heathland. Biodiversity \& Conservation 1:63-79.

Usher MB, Thompson DBA. 1993. Variation in the upland heathlands of Great Britain: Conservation importance. Biological Conservation 66:69-81.

Valkó O, Venn S, Żmihorski M, Biurrun I, Labadessa R, Loos J. 2018. The challenge of abandonment for the sustainable management of Palaearctic natural and semi-natural grasslands. Hacquetia 17:5-16.

Van Wieren SE. 1995. The potential role of large herbivores in nature conservation and extensive land use in Europe. Biological Journal of the Linnean Society 56:11-23.

Vera FWM. 2000. Grazing Ecology and Forest History. Wallingford, Oxon, NY: CABI.

Vickery JA, Tallowin JR, Feber RE, Asteraki EJ, Atkinson PW, Fuller RJ, Brown VK. 2001. The management of lowland neutral grasslands in Britain: effects of agricultural practices on birds and their food resources. Journal of Applied Ecology 38:647-664.

Warren SD, Büttner R. 2008a. Active military training areas as refugia for disturbance-dependent endangered insects. Journal of Insect Conservation 12:671-676.

Warren SD, Büttner R. 2008b. Relationship of Endangered Amphibians to Landscape Disturbance. The Journal of Wildlife Management 72:738-744.

Warren SD, Holbrook SW, Dale DA, Whelan NL, Elyn M, Grimm W, Jentsch A. 2007. Biodiversity and the heterogeneous disturbance regime on military training lands. Restoration Ecology 15:606-612.

Webb NR. 1998. The traditional management of European heathlands. Journal of Applied Ecology 35:987-990.

Wesche K, Krause B, Culmsee H, Leuschner C. 2012. Fifty years of change in Central European grassland vegetation: Large losses in species richness and animal-pollinated plants. Biological Conservation 150:76-85.

Wilson JB, Peet RK, Dengler J, Pärtel M. 2012. Plant species richness: the world records. Journal of Vegetation Science 23:796-802.

Wrage N, Strodthoff J, Cuchillo HM, Isselstein J, Kayser M. 2011. Phytodiversity of temperate permanent grasslands: ecosystem services for agriculture and livestock management for diversity conservation. Biodiversity and Conservation 20:3317-3339.

Zachos FE, Hartl GB. 2011. Phylogeography, population genetics and conservation of the European red deer Cervus elaphus. Mammal Review 41:138-150. 
PART II 


\section{Chapter 1}

Soil $\mathrm{pH}$ and phosphorus drive species composition and richness in semi-natural heathlands and grasslands unaffected by twentiethcentury agricultural intensification
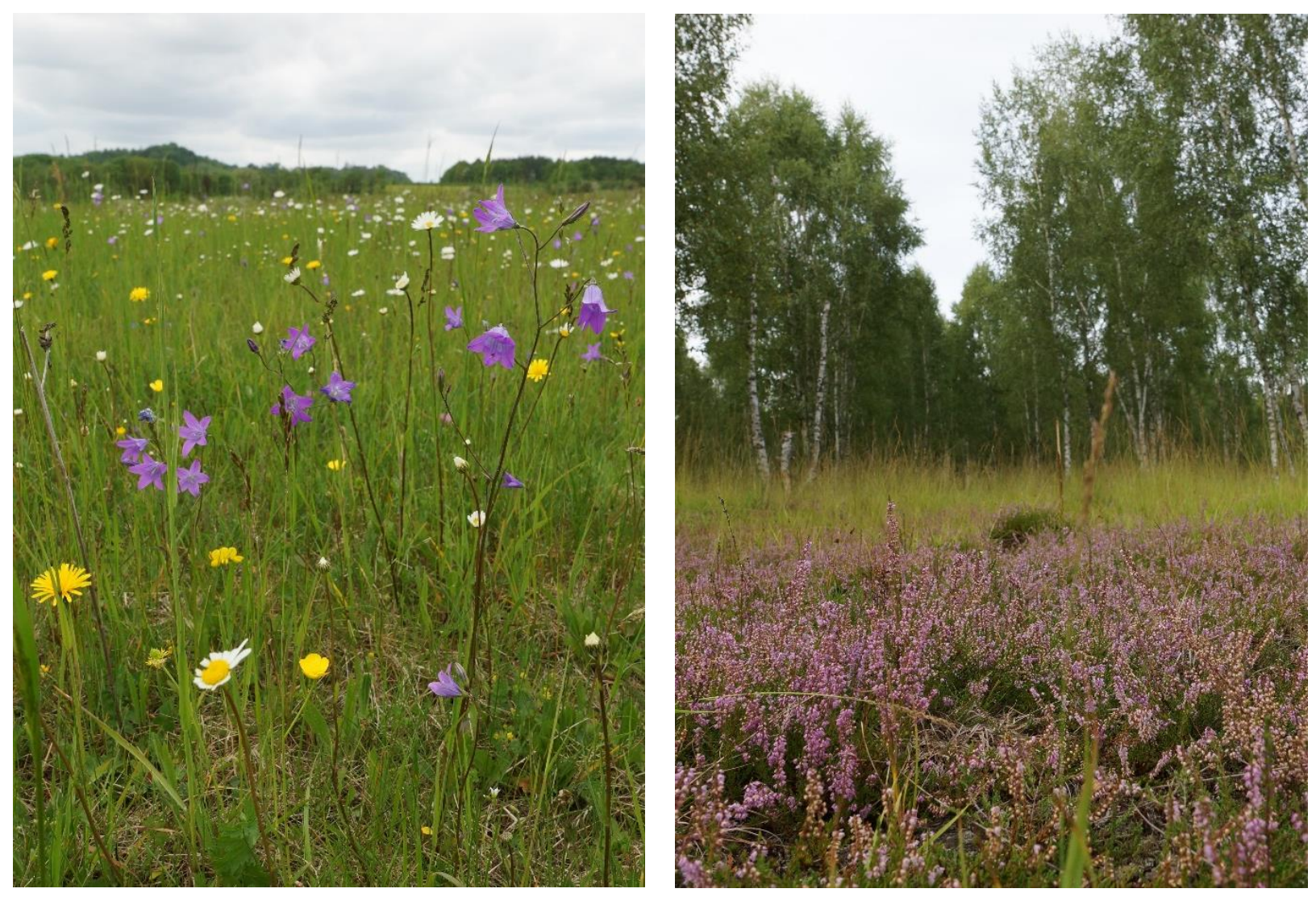

Pictures: Anya Wichelhaus

This chapter is an Accepted Manuscript of an article published by Taylor \& Francis in Plant Ecology \& Diversity on 21 May 2018, available online:

https://www.tandfonline.com/doi/10.1080/17550874.2018.1471627.

Riesch F, Stroh HG, Tonn B, Isselstein J. 2018. Soil pH and phosphorus drive species composition and richness in semi-natural heathlands and grasslands unaffected by twentiethcentury agricultural intensification. Plant Ecology \& Diversity. 11:239-253. 


\begin{abstract}
Background: Increased soil phosphorus $(\mathrm{P})$ caused by agricultural intensification has been associated with decreased plant species richness (SR) in central Europe. How plant communities and soil $\mathrm{P}$ gradients are related in unimproved open habitats remains unclear.

Aims: The aim of this article was to characterise the relationship between soil chemical parameters and plant species composition and richness in unimproved open habitats.

Methods: The influence of soil chemical parameters ( $\mathrm{pH}, \mathrm{P}, \mathrm{K}, \mathrm{Mg}$ ) on species composition was assessed, using data from 40 heathland and 54 grassland plots, by non-metric multidimensional scaling and permutational multivariate analysis of variance. The relationship between soil chemical parameters and SR was tested by linear mixed effects models.

Results: A direct relationship between heathland community composition and $\mathrm{pH}$ was observed, explaining $10 \%$ of variation in species composition, while $\mathrm{P}, \mathrm{Mg}$ and $\mathrm{pH}$ together explained $17 \%$ of variation in grassland composition. In heathlands, SR increased with increasing $\mathrm{pH}$, whereas in grasslands, SR decreased with increasing soil P.

Conclusions: Soil chemical parameters were substantially related to plant community composition and richness. In an area spared from a century of agricultural intensification, reduced $\mathrm{pH}$ appeared to constrain SR in heathlands, while even slight $\mathrm{P}$ increases $\left(<10 \mathrm{mg} \mathrm{kg}^{-1}\right)$ depressed plant SR in semi-natural grasslands.
\end{abstract}

\title{
Keywords
}

Acidification; Ellenberg indicator values; military training area; Natura 2000; open habitat conservation; plant community composition; plant functional strategies

\section{Introduction}

Increasing soil phosphorus $(\mathrm{P})$ is generally related to decreasing plant species richness, for instance in forests (Dumortier et al. 2002; De Keersmaeker et al. 2004; Dorrough et al. 2006) and different grassland systems (Janssens et al. 1998; Critchley et al. 2002; Marini et al. 2007; Gilbert et al. 2009; Hejcman et al. 2010; Ceulemans et al. 2013). This can be explained by increased growth of competitive species (Grime 1979) at higher $P$ availability levels and resulting exclusion of less productive species via light competition (Hautier et al. 2009). It has even been proposed that P rather than nitrogen $(\mathrm{N})$ - whose negative effects on plant diversity have been widely reported (e.g. Zechmeister et al. 2003; Stevens et al. 2004; Bobbink et al. 2010; Field et al. 2014; Tang et al. 2017) — is the main factor associated with species richness (SR) and the persistence of endangered plant species in temperate grassland systems (Wassen et al. 2005; Ceulemans et al. 2013), but see Soons et al. (2017). 
In the biogeochemical P cycle, bacteria, fungi and plants incorporate phosphate released from weathered primary minerals into biomass, while inorganic $\mathrm{P}$ is released by the decomposition and mineralisation of organic substances (Cross and Schlesinger 1995). In natural systems, usually only a small proportion of the total $\mathrm{P}$, mostly derived from soil organic matter, is bioavailable (Stewart and Tiessen 1987). For this reason, the use of $\mathrm{P}$ fertilisers has been central to agricultural intensification. Consequently, since the first inorganic fertilisers were developed by the treatment of phosphate rock in the middle of the nineteenth century and especially from the 1950s onwards (Smil 2000), soil P status in Europe has increased dramatically (Barberis et al. 1995; Tunney et al. 2003). Recent studies pointed out that restoring pre-industrialised soil $\mathrm{P}$ levels can take from several decades up to centuries depending on soil properties, successional vegetation and management (MacDonald et al. 2012; Schelfhout et al. 2015).

Little is known about the influence of plant-available $\mathrm{P}$ and other soil chemical parameters on plant communities of open habitats, such as semi-natural grasslands and heathlands, where P levels have not been significantly anthropogenically enhanced. Earlier studies usually included agriculturally improved habitats and covered a wide geographical range, differences in management or different soil and vegetation types. This resulted in soil $\mathrm{P}$ concentrations spanning up to several orders of magnitude and different shapes (e.g. hump-shaped or negative exponential) of the relationship between soil P and SR (Table S1). How the natural low-level variation in soil $\mathrm{P}$ that is not governed by agricultural input relates to plant species composition and richness within different open habitat types still needs to be explored.

As few unimproved areas remain in central Europe (Hodgson et al. 2005), we selected a study area differing from the surrounding landscape to fill this knowledge gap. We took advantage of the fact that military land use generally precludes intensive agriculture but also requires the maintenance of open habitats. That military training areas can have high nature conservation value has already been recognised, for instance regarding plants and butterflies (Cizek et al. 2013), grasshoppers and ground beetles (Warren and Büttner 2008a) or amphibians (Warren and Büttner 2008b). In our study area, Grafenwöhr military training area (GTA) in Bavaria, Germany, regular agricultural land use had stopped more than 100 years ago, leading to a soil which has remained unaffected by intensive agriculture. We focused on the two most important open habitat types within GTA, the Natura 2000 habitat types European dry heaths (hereafter 'heathlands') and lowland hay meadows (hereafter 'grasslands'). Conservation interest in both of these habitats is high, because they have been facing a rapid decline throughout Europe since the twentieth century (European Environment Agency 2015). Our interest lay mainly in the within-habitat gradients in soil chemical parameters and their relationship with plant species composition and richness and not in comparing the inherent habitat-type-specific differences in nutrient availability (very low in heathlands, higher in grasslands) or species composition. Therefore, we addressed heathlands and grasslands separately in multivariate and univariate analyses. We measured soil $\mathrm{P}$, potassium $(\mathrm{K})$, magnesium $(\mathrm{Mg})$ and $\mathrm{pH}$. Other factors relevant to plant community composition and SR (e.g. water and $\mathrm{N}$ availability) were included by analysing ecological and functional 
gradients in Ellenberg indicator values (EIV; Ellenberg and Leuschner 2010) and species strategy types according to Grime (1979).

As our study area did not receive nutrient input via fertilisation in the twentieth century, we anticipated a comparably low soil P status. We expected that, in contrast to the generally established negative species richness-soil P relationship, a positive relationship between plant SR and soil P might occur under such conditions. We hypothesised that plant species with higher $\mathrm{P}$ requirements would be absent where plant-available P concentrations fell below a certain threshold (Tilman 1982), below which only species tolerating the stress of nutrient deficiency could persist. As a consequence, the relationship between SR and soil P would be hump-shapedsimilar to the proposed unimodal diversity-productivity relationship (Grime 1979; Fraser et al. 2015). Specifically, in our study, we hypothesised that (1) when plantavailable soil $\mathrm{P}$ concentration was extremely low, $\mathrm{P}$ could have a positive effect on plant species richness, but the relationship would become negative when $\mathrm{P}$ availability increased, i.e. the species richness-soil $\mathrm{P}$ relationship would be humpshaped; (2) increasing soil $\mathrm{P}$ would be accompanied by a shift in plant community composition towards more competitive and less stress-tolerant plant species. We expected that hypotheses (1) and (2) would hold true within both semi-natural heathlands and grasslands.

\section{Materials and methods}

\section{Study area}

The study was conducted on the GTA in Bavaria, Germany (centred at $49^{\circ} 40^{\prime}$ 56" N, $11^{\circ} 47^{\prime} 20^{\prime \prime}$ E; Figure S1), a United States Army Garrison since 1947. GTA lies at 450 to $500 \mathrm{~m}$ above sea level in the Upper Palatine-Upper Main Hills region (or Oberpfälizisch-Obermainisches Hügelland in German), the western part bordering the Franconian Jura upland. Long-term annual averages of temperature and precipitation (1981-2010, mean \pm SE of four weather stations of the German Weather Service (Deutscher Wetterdienst, DWD) in the immediate vicinity) are $8.3 \pm 0.04{ }^{\circ} \mathrm{C}$ and $701 \pm 4 \mathrm{~mm}$, respectively. GTA covers ca. $230 \mathrm{~km}^{2}$ with $134 \mathrm{~km}^{2}$ of forest and $95 \mathrm{~km}^{2}$ of different open habitat types.

The older part of GTA (almost $100 \mathrm{~km}^{2}$ ) was acquired by the Bavarian Military administration between 1907 and 1909. Further $140 \mathrm{~km}^{2}$ were added to the western part of the area in 1938/39. Today, 85\% of GTA are included in the Natura 2000 network. Open land areas on GTA are mainly used as artillery firing points, which implies occasional intensive vehicle traffic. In the 1960s and 1970s, intensive training with heavy vehicles led to the destruction of vegetation cover and severe soil compaction over large areas. Subsequent landscape restoration measures included loosening of soils and tree planting and reseeding with common agricultural grassland seeds. In recent decades, reseeding was limited to extremely deteriorated areas and seeds contained local plant species (Table S2). From the start of the military land use, no fertiliser has been applied. Regular open land management includes mowing of meadows by local farmers at the beginning of July after the main 
flowering phase of grasses and grazing by wildlife, especially by abundant red deer (Cervus elaphus).

Field sampling

Vegetation surveys were conducted in two different open habitat types (Figure S1), both protected under the European Habitats Directive. We selected 10 heathland sampling sites representing the habitat type 4030, European dry heaths (total area on GTA: $463 \mathrm{ha}$ ) belonging to the Vaccinio-Callunetum vulgaris association, occurring on Triassic sandstone and dystrophic sandy soils in the eastern part of GTA. In the western third of GTA, characterised by calcareous soils derived from Jurassic limestone sediments (Warren and Büttner 2008a), we selected nine grassland sampling sites within the habitat type 6510, lowland hay meadows (total area on GTA: $340 \mathrm{ha}$ ) belonging to the Arrhenatherion elatioris vegetation alliance. For reasons of safety and to avoid frequently disturbed areas, the main ordnance impact areas covering the south-eastern part of GTA were excluded from the sampling scheme. Selection criteria for sampling sites were (1) an approximate area size of at least 1 ha ( 0.5 ha in heathlands); (2) the habitat type-specific species composition based on the Bavarian monitoring scheme for Natura 2000 habitats (Lang and Zintl 2010). Elevation of heathland sites ranged between 438 and $500 \mathrm{~m}$, while grasslands were distributed between 422 and $536 \mathrm{~m}$. According to the German Federal Forests Division, soil moisture in heathlands was categorised as ranging from moderately dry to moderately and periodically wet, while grasslands were moderately moist or moderately periodically wet (Bundesanstalt für Immobilienaufgaben 2003). The sampled sites had not been reseeded for at least 20 years.

At each sampling site, four (heathlands) or six (grasslands) plots of $5 \mathrm{~m} \times 5 \mathrm{~m}$ in size were selected based on floristic homogeneity between and within the plots at each sampling site. The plots were surveyed by the same person between June and July 2014 (grasslands) and between the end of July and end of September 2014 (heathlands). One heathland and one grassland site each was visited in 2015. In total, 40 heathland and 54 grassland plots were recorded.

From the total aboveground plant biomass $(100 \%)$, the relative biomass contribution of each plant species was visually estimated (Klapp 1965). Nomenclature follows Jäger (2011) for plants and Mucina et al. (2016) and Rennwald (2000) for vegetation types. Some species of the species-rich Alchemilla genus could not be identified with certainty and were collectively recorded as Alchemilla species. The same holds true for sp. of the taxa Crataegus, Hieracium, Leontodon, Ononis and Silenoideae. The following plot characteristics were recorded: percent cover of vascular plants (cover), average height of herbaceous canopy (canopy height) as well as the ratio of relevant functional groups (FG ratio), i.e. grasses to forbs including legumes in grasslands and woody to herbaceous vegetation in heathlands. Percent cover and species composition of the cryptogam layer were recorded but not included in further analyses. Soil samples to a depth of $10 \mathrm{~cm}$ were taken with a Pürckhauer soil corer, which was randomly inserted into the soil 10 times per plot.

Soil samples were analysed for extractable $\mathrm{P}, \mathrm{K}$ and $\mathrm{Mg}$ concentrations and $\mathrm{pH}$, following German agricultural standard soil analysis (LUFA Nord-West 2017). P and 
$\mathrm{K}$ were extracted according to the calcium-acetate-lactate (CAL) method (Schüller 1969; Hoffmann 1991) and $\mathrm{Mg}$ was extracted with calcium chloride $\left(\mathrm{CaCl}_{2}\right)$. Soil $\mathrm{pH}$ was determined in a $0.01 \mathrm{M} \mathrm{CaCl}_{2}$ solution (Hoffmann 1991). The elemental concentrations were determined by inductively coupled plasma optical emission spectrometry (iCAP 6300 DUO ICP OMS, Thermo Fisher Scientific, Waltham, MA, US). All information on plant species biomass percentages and plot characteristics are supplied as supplementary data files.

\section{Data analyses}

For all data processing and statistics, we used $\mathrm{R}$ version 3.1 (R Core Team 2015). SR was calculated as the number of vascular plant species per plot. To characterise the ecological requirements and functional strategy of each plant species recorded, we used EIV (Ellenberg and Leuschner 2010) for soil moisture $\left(E_{F}\right)$, soil reaction $\left(E_{R}\right)$ and soil nutrient availability $\left(\mathrm{E}_{\mathrm{N}}\right)$, and strategy types according to Grime (1979). Plant species' strategy types were converted to a numeric CSR signature ( $\mathrm{C}$ - competitive strategy, $\mathrm{S}$ - stress-tolerant strategy, $\mathrm{R}$ - ruderal strategy) as described by Hunt et al. (2004). For each plot, we then calculated the average value of each EIV or strategy type weighted by each species' relative biomass contribution to total biomass.

Our statistical analyses at habitat-type level took four steps: (1) the general variation in species composition; (2) the relationship between soil chemical parameters and species composition; (3) the relationship between soil chemical parameters and SR;

(4) Pearson correlations between EIV or CSR-signature components and SR or soil P.

First, we explored the variation in vegetation composition within each habitat type using non-metric multidimensional scaling (NMDS; Minchin 1987) implemented in the $\mathrm{R}$ package vegan (Oksanen et al. 2015). We used the Bray-Curtis index as dissimilarity measure. The Kulczyński dissimilarity measure yielded qualitatively similar results. The NMDS process included Wisconsin double standardisation of square-root-transformed raw data. In order to facilitate comparisons between the two investigated habitat types, NMDS plots were rotated, so that the $\mathrm{pH}$ gradient paralleled the first NMDS axis. We examined vegetation responses to soil chemical parameters and plot-specific ecological characteristics by fitting linear trends as well as non-parametrically smoothed surfaces (Virtanen et al. 2006). The significance of vectors was tested by 10,000 permutations. Significance of surfaces was tested by generalised additive models (GAMs) in the mgcv package (Wood 2016). A separate smooth term was used to fit sampling site as random effect and variance structures were specified if necessary to account for heteroscedastic within-group errors. In the grassland GAMs, soil P and Mg were log-transformed.

Second, we tested relationships between soil chemical parameters and vegetation community composition by permutational multivariate analysis of variance (PerMANOVA). We transformed species biomass percentages of heathlands and grasslands analogously to the NMDS process and applied the function adonis (Anderson 2001) on the Bray-Curtis distance matrices. To account for the lack of independence of plots, we constrained permutations $(n=10,000)$ within sampling sites. 
Third, we assessed the relationship between soil chemical parameters and plant SR using linear mixed effects (LME) models in the package nlme (Pinheiro et al. 2015). Sampling site was included as a random intercept. All explanatory variables were centred at zero mean and scaled to 0.5 standard deviation prior to analysis (Grueber et al. 2011), which allowed to directly compare the magnitudes of their effects. To allow for hump-shaped SR relationships (Hypothesis 1), we added quadratic terms of the soil nutrients $(\mathrm{P}, \mathrm{K}, \mathrm{Mg})$. Normality of residuals of the global model was checked by visual inspection of quantile-quantile plots and Shapiro-Wilk test (heathlands: $p=0.700$; grasslands: $p=0.913)$. The homogeneity of variance was assessed based on plots of residuals vs. fitted values and residuals vs. predictors (Zuur et al. 2009). Variance inflation factors for each parameter in the global model were well below 5 (Table 3); therefore, we could largely exclude multicollinearity as a confounding factor to our results (Dormann et al. 2013). We ranked all models nested in the global model according to the second-order Akaike information criterion (AICc accounting for small sample size using the MuMIn package (Barton 2016)). According to Nakagawa and Schielzeth (2013), we expressed the variance explained by fixed and random effects as conditional coefficient of determination $\left(R_{(c)}{ }^{2}\right)$ and the variance explained by fixed effects alone as marginal coefficient of determination $\left(R_{(m)}{ }^{2}\right)$. As no single model reached strong support, i.e. no Akaike weight (the probability of a model to be the actual best model (Wagenmakers and Farrell 2004)) $w_{\mathrm{i}} \geq 0.9$, we carried out multimodel averaging to overcome model selection uncertainty (Burnham and Anderson 2002). We averaged weighted parameter estimates over the set of models with cumulative Akaike weight, acc $w_{\mathrm{i}}, \leq 0.95$. This set of models could be interpreted as $95 \%$ confidence set to the best approximating model (Burnham and Anderson 2002). For each parameter, we estimated the relative importance as the sum of Akaike weights over all models including the explanatory variable in the $95 \%$ confidence set. Relative importance ranged from $0 \%$ (parameter not given in any model in the confidence set) to $100 \%$ (parameter appears in all models of the confidence set). We visualised the model-averaged effects of the most important variables ( $\mathrm{pH}$ and $\mathrm{P}$ ) on plant SR keeping potential other parameters constant at their mean. Finally, we calculated Pearson correlation coefficients to evaluate whether EIV or the distribution of plant CSR-strategy types correlated with SR and whether CSR-strategy types correlated with soil P.

\section{Results}

On average, we found $14.1 \pm 0.8$ (mean \pm standard error) vascular plant species per $25 \mathrm{~m}^{2}$ in heathlands and $45.9 \pm 0.8$ species in grasslands. The total number of species was 67 in heathlands and 154 in grasslands (Table S3). Twenty of the plant species occurred in both habitats.

\section{Site conditions}

Edaphic conditions differed considerably between heathland and grassland sites (Table 1). Soil $\mathrm{pH}$ in heathlands was acidic ( $\mathrm{pH} 3.3-4.7)$, whereas $\mathrm{pH}$ in grasslands ranged from moderately acidic ( $\mathrm{pH} 4.8)$ to neutral $(\mathrm{pH}$ 6.8). $\mathrm{P}$ and $\mathrm{Mg}$ concentrations were generally lower in heathlands $\left(0.7-10.5 \mathrm{mg} \mathrm{P} \mathrm{kg}{ }^{-1} ; 21.1-66.7 \mathrm{mg} \mathrm{Mg} \mathrm{kg}^{-1}\right)$ than 
Table 1: Summary of soil chemical parameters averaged over 40 heathland plots and 54 grassland plots, Grafenwöhr military training area (GTA) in Bavaria, Germany. Values for P (CAL), $\mathrm{K}(\mathrm{CAL})$ and $\mathrm{Mg}\left(\mathrm{CaCl}_{2}\right)$ are given in $\mathrm{mg} \mathrm{kg}^{-1}$ top soil dry matter; $\mathrm{pH}$ was measured in $\mathrm{CaCl}_{2}$.

\begin{tabular}{lllllllllll}
\hline & \multicolumn{4}{c}{ Heathlands } & & \multicolumn{4}{c}{ Grasslands } \\
\cline { 2 - 4 } \cline { 8 - 10 } Parameter & Min & Max & Mean & SEM & & Min & Max & Mean & SEM \\
\hline pH & 3.3 & 4.7 & 3.9 & 0.04 & & 4.8 & 6.8 & 5.7 & 0.06 \\
$\mathbf{P}$ & 0.7 & 10.5 & 4.2 & 0.30 & & 4.6 & 28.8 & 11.7 & 0.74 \\
$\mathbf{K}$ & 20.3 & 84.7 & 47.3 & 2.72 & & 28.6 & 85.3 & 52.1 & 1.84 \\
$\mathbf{M g}$ & 21.1 & 66.7 & 39.2 & 1.74 & & 50.4 & 439.0 & 139.1 & 11.39 \\
\hline
\end{tabular}

in grasslands (4.6-28.8 $\mathrm{mg} \mathrm{P} \mathrm{kg}^{-1}$; 50.4-439.0 $\mathrm{mg} \mathrm{Mg} \mathrm{kg}^{-1}$ ) but habitat types overlapped in their ranges of $\mathrm{P}$ concentration. $\mathrm{K}$ availability was similar in heathland (20.3-84.7 $\mathrm{mg} \mathrm{K} \mathrm{kg}^{-1}$ ) and grassland soils (28.6-85.3 $\left.\mathrm{mg} \mathrm{K} \mathrm{kg}^{-1}\right)$. In general, heathland plots were characterised by lower vascular plant cover and canopy height relative to grasslands. Cryptogams were present in all but one heathland plots and in 48 out of the 54 grassland plots ranging in percent cover from $2 \%$ to $40 \%$ and from $0.04 \%$ to $50 \%$, respectively. In heathlands, the typical moss species Pleurozium schreberi and Hypnum cupressiforme as well as different lichens of the Cladonia genus were abundant. In grasslands, common moss species (Brachythecium rutabulum, Rhytidiadelphus squarrosus and Cirriphyllum piliferum) occurred. Weighted mean EIV indicated that heathland vascular plant communities were composed of species adapted to (extreme) acidity, soil infertility and different soil moisture regimes ranging from dry to moist, while in grasslands vascular plant species composition indicated intermediate fertility, weak acidity and intermediate soil moisture. In heathland communities, the R strategy was scarcely represented, while in grasslands C, S and R strategy occurred in equal proportions (Table S4).

\section{Gradients in species composition}

The two-dimensional NMDS analysis of species biomass percentages per plot reached a solution with stress of 0.19 for heathlands (linear fit $R^{2}=0.83$, non-metric fit $R^{2}=0.96$ ) and 0.20 for grasslands (linear fit $R^{2}=0.80$, non-metric fit $R^{2}=0.95$ ). See Appendix S1 and Figure S2 for more detailed information on the ordination results.

Using smoothed surfaces to fit non-linear relationships between plot characteristics and NMDS scores most often yielded substantially better $R^{2}$ than using linear vectors, especially in heathlands (Table S5). High SR in heathlands was accompanied by elevated $\mathrm{pH}$ and canopy height (Figure 1(a)). In grasslands, species-rich sites were characterised by high $\mathrm{pH}$, high $\mathrm{E}_{\mathrm{R}}$ and $\mathrm{E}_{\mathrm{N}}$ and a relatively high share of the $\mathrm{C}$ strategy component on the one hand and on the other hand by low-to-intermediate cover, low $\mathrm{E}_{\mathrm{F}}$ and reduced share of the R strategy component (Figure 1(b)). 


\section{Effects of soil chemical parameters on species composition and richness}

We directly tested the relationship of soil chemical parameters with vegetation community composition via PerMANOVA. In heathlands, $\mathrm{pH}$ was the only soil chemical parameter significantly $(\phi<0.05)$ related to vegetation composition (Table 2). By contrast, grassland species composition was related to $\mathrm{pH}, \mathrm{Mg}$ and $\mathrm{P}$. Of the total variation in species composition, soil chemical parameters significantly explained $10 \%$ in heathlands and $17 \%$ in grasslands.

For both habitat types, models explaining vascular plant SR based on soil chemical parameters ( $\mathrm{pH}, \mathrm{P}, \mathrm{K}$ and $\mathrm{Mg}$ ) yielded high goodness-of-fit, with a substantial amount of variance explained by the fixed effects. The explained variance was higher in heathlands (Table S6; $R_{(m)}{ }^{2}$ and $R_{(c)}{ }^{2}$ of models in the $95 \%$ confidence set ranged between 0.51 and 0.56 and 0.68 and 0.73 , respectively) than in grasslands $\left(R_{(m)}{ }^{2}\right.$ and $\mathrm{R}_{(c)}{ }^{2}$ ranged between 0.27 and 0.44 and 0.37 and 0.50 , respectively). The relative variable importance was highest for $\mathrm{pH}$ in heathlands and for $\mathrm{P}$ followed by $\mathrm{pH}$ in grasslands (Table 3).

Evidence was strong (i.e. the $95 \%$ confidence interval of these coefficient estimates did not bracket zero) for a steep increase of SR with $\mathrm{pH}$ in heathlands and a steep decrease of SR with soil P in grasslands, especially for low levels of P (CAL$\mathrm{P} \leq 10 \mathrm{mg} \mathrm{kg}^{-1}$, Table 3, Figure 2). In grasslands, the positive effect of $\mathrm{pH}$ on SR was weaker than in heathlands and less evident (the $95 \%$ confidence interval of the coefficient estimate slightly overlapped with zero). Soil P was not related to plant SR in heathland plots. The apparent mismatch between the patterns of the heathland observations and the predicted P effect in Figure 2(b) stemmed from a significant negative correlation between heathland soil $\mathrm{pH}$ and $\mathrm{P}$ (Pearson $r=-0.42, p=0.008$ ).

Table 2: Results of the PerMANOVA analyses on the relationship between soil chemical parameters and vegetation composition in heathlands and grasslands, Grafenwöhr military training area (GTA) in Bavaria, Germany. Each variable was used as final explanatory variable after all the others in the model. $R^{2}$ shows each variable's share of the total variation in the dataset.

\begin{tabular}{llllll}
\hline Model & Parameter & $\mathrm{df}$ & F-value & $\mathrm{R}^{2}$ & $p^{\mathrm{a}}$ \\
\hline Heathlands & $\mathrm{P}$ & $\mathbf{1}$ & 2.87 & 0.06 & 0.070 \\
& $\mathbf{p H}$ & $\mathbf{1}$ & $\mathbf{5 . 0 1}$ & $\mathbf{0 . 1 0}$ & $\mathbf{0 . 0 2 4}$ \\
& $\mathrm{Mg}$ & 1 & 1.88 & 0.04 & 0.080 \\
& $\mathrm{~K}$ & $\mathbf{1}$ & 1.47 & 0.03 & 0.359 \\
& Residuals & 35 & & 0.71 & \\
Grasslands & $\mathbf{P}$ & $\mathbf{1}$ & $\mathbf{2 . 6 9}$ & $\mathbf{0 . 0 4}$ & $\mathbf{0 . 0 0 4}$ \\
& $\mathbf{p H}$ & $\mathbf{1}$ & $\mathbf{4 . 8 4}$ & $\mathbf{0 . 0 8}$ & $\mathbf{0 . 0 2 3}$ \\
& $\mathbf{M g}$ & $\mathbf{1}$ & $\mathbf{3 . 2 6}$ & $\mathbf{0 . 0 5}$ & $\mathbf{0 . 0 2 2}$ \\
& $\mathrm{K}$ & 1 & 1.26 & 0.02 & 0.176 \\
& Residuals & 49 & & 0.78 & \\
\hline
\end{tabular}

aBold type face indicates statistical significance $(p<0.05)$ 
Removing the outlying maximum value of heathland soil $\mathrm{P}$ did not qualitatively change the results. In grasslands, soil $\mathrm{pH}$ and $\mathrm{P}$ did not correlate (Pearson $r=0.06$, $p=0.666)$.

\section{a Heathlands}
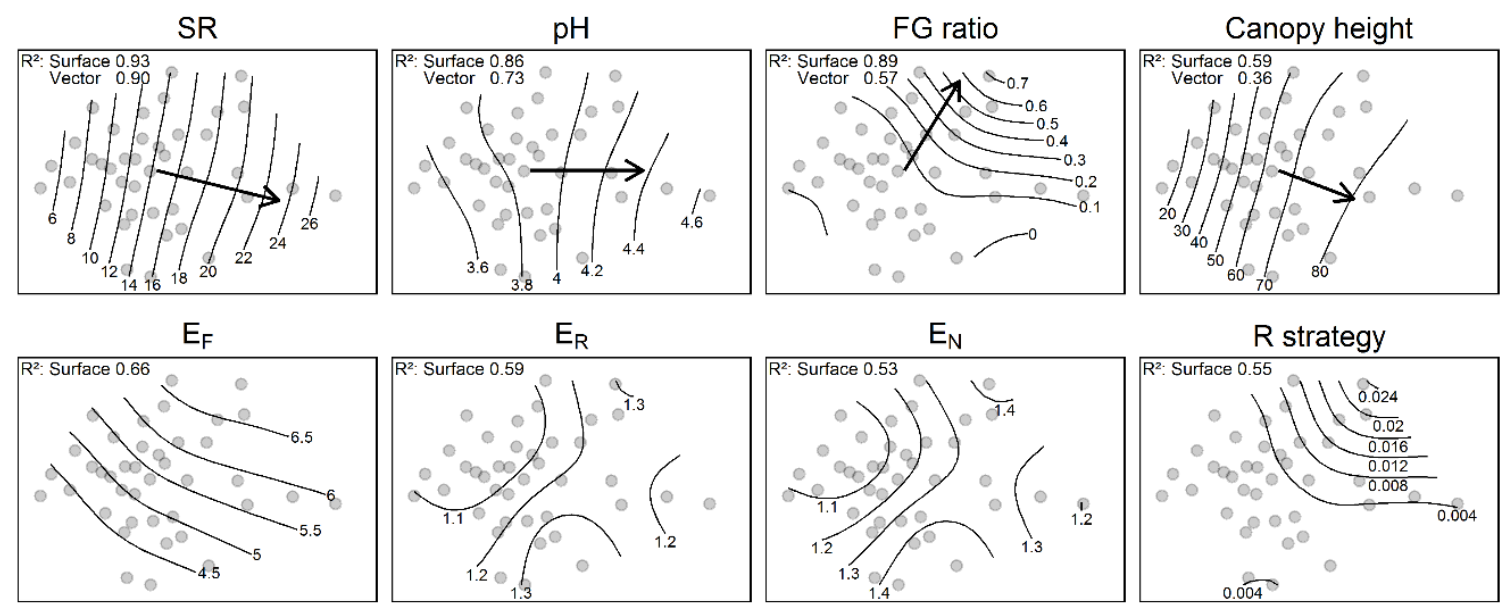

\section{b Grasslands}
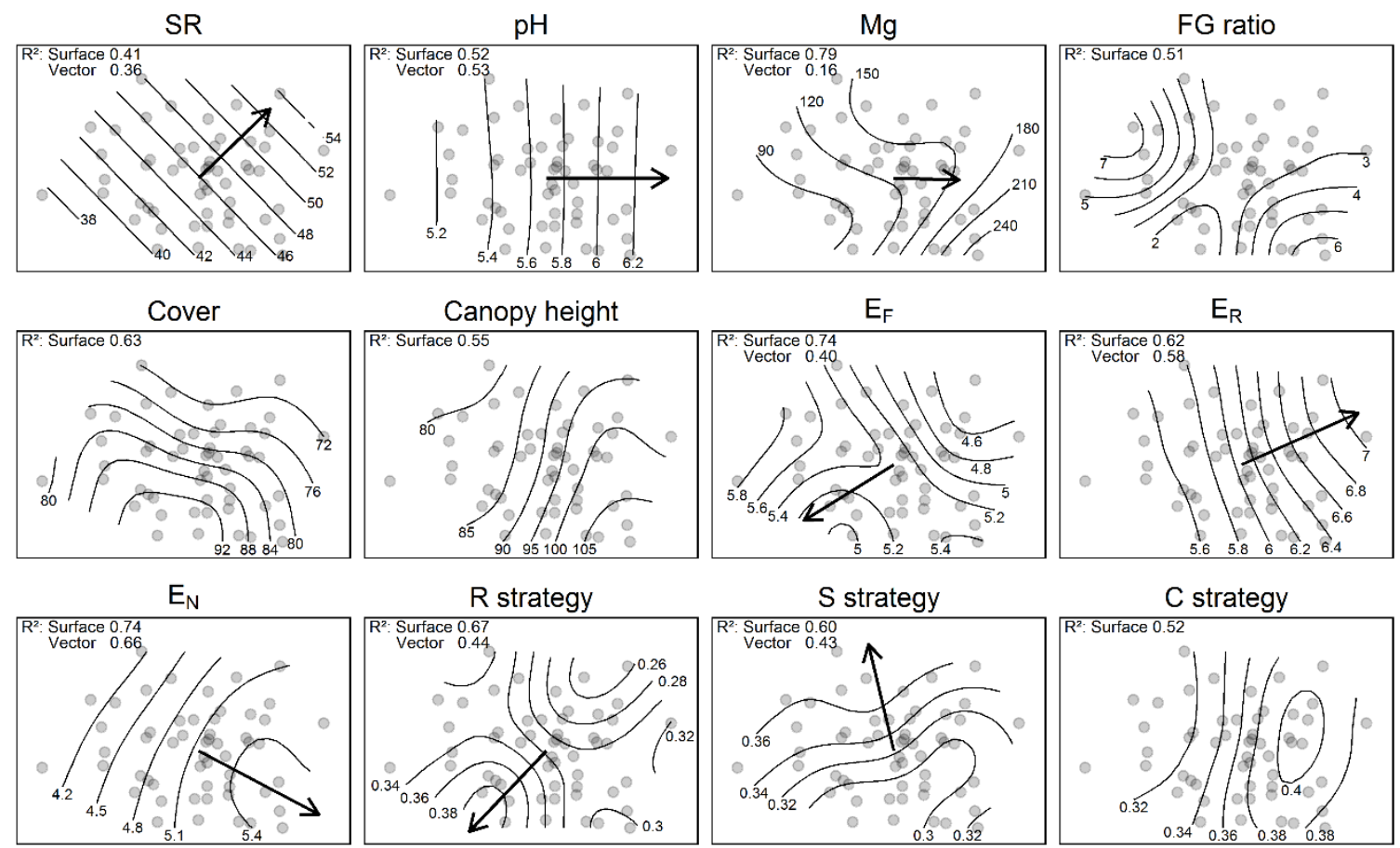

Figure 1: NMDS ordination (cf. Figure S2) of sampling sites in (a) heathlands and (b) grasslands, Grafenwöhr military training area (GTA) in Bavaria, Germany, with significant $(p<0.05$, cf. Table S5) regression surfaces and/or vectors of plot characteristics (SR, species richness; $\mathrm{pH}$, soil $\mathrm{pH}$-value; $\mathrm{Mg}$, soil $\mathrm{Mg}$ concentration [ $\mathrm{mg} \mathrm{kg}^{-1}$; $\mathrm{FG}$ ratio, ratio of functional groups, i.e. woody to herbaceous vegetation in heathlands and grasses to forbs incl. legumes in grasslands; canopy height, average height of herbaceous canopy; cover, percent cover of vascular plants; biomass percentage weighted averages of Ellenberg indicator values (EIV) and CSR-signature components - $\mathrm{E}_{\mathrm{F}}$, EIV for soil moisture; $\mathrm{E}_{\mathrm{R}}$, EIV for soil reaction; $\mathrm{E}_{\mathrm{N}}$, EIV for soil fertility; R strategy, ruderal; S strategy, stress-tolerator; C strategy, competitor). Grey circles represent plot scores. 
Table 3: Soil chemical parameters determining vascular plant species richness, Grafenwöhr military training area (GTA) in Bavaria, Germany. Results of model-averaging based on separate linear mixed effects models for heathlands and grasslands including relative importance, model-averaged standardised coefficients, lower and upper bound of 95\% confidence interval (CI) and variance inflation factor (VIF) for the global model.

\begin{tabular}{|c|c|c|c|c|c|c|}
\hline \multirow[b]{2}{*}{ Model } & \multirow[b]{2}{*}{ Parameter } & \multirow{2}{*}{$\begin{array}{l}\text { Relative } \\
\text { importance }(\%)^{a}\end{array}$} & \multirow{2}{*}{$\begin{array}{l}\text { Averaged } \\
\text { estimate }^{b}\end{array}$} & \multicolumn{2}{|c|}{$\mathrm{CI}$} & \multirow[b]{2}{*}{ VIF } \\
\hline & & & & Lower & Upper & \\
\hline \multirow[t]{7}{*}{ Heathlands } & $\mathrm{pH}$ & 100 & 7.67 & 4.68 & 10.66 & 1.79 \\
\hline & $\mathrm{Mg}$ & 35 & 0.59 & -1.75 & 2.93 & 3.21 \\
\hline & $\mathrm{K}^{2}$ & 27 & 0.59 & -2.63 & 3.81 & 1.45 \\
\hline & K & 22 & 0.22 & -1.46 & 1.91 & 2.62 \\
\hline & $\mathrm{P}^{2}$ & 22 & 0.16 & -1.13 & 1.44 & 1.46 \\
\hline & $\mathrm{Mg}^{2}$ & 21 & -0.25 & -2.22 & 1.72 & 1.97 \\
\hline & $\mathrm{P}$ & 17 & -0.04 & -1.34 & 1.25 & 1.80 \\
\hline \multirow[t]{7}{*}{ Grasslands } & $\mathbf{P}$ & 100 & -8.85 & -15.58 & -2.11 & 4.98 \\
\hline & $\mathrm{pH}$ & 90 & 3.31 & -0.27 & 6.88 & 1.22 \\
\hline & $\mathrm{P}^{2}$ & 71 & 3.33 & -2.30 & 8.97 & 3.75 \\
\hline & $\mathrm{K}^{2}$ & 66 & 3.26 & -3.02 & 9.54 & 1.37 \\
\hline & K & 43 & 1.02 & -2.14 & 4.18 & 1.41 \\
\hline & $\mathrm{Mg}$ & 20 & 0.06 & -1.88 & 2.00 & 3.03 \\
\hline & $\mathrm{Mg}^{2}$ & 20 & -0.01 & -1.53 & 1.51 & 2.61 \\
\hline
\end{tabular}

${ }^{a}$ The importance of each variable (sum of AICc weights) within the $95 \%$ confidence set of all possible models

bCoefficient averaged over the $95 \%$ confidence set of all models

Correlation tests largely confirmed the SR patterns arising from the NMDS in grasslands (Table 4). We furthermore found significant positive correlations between heathland $\mathrm{SR}$ and $\mathrm{E}_{\mathrm{F}}, \mathrm{E}_{\mathrm{R}}, \mathrm{E}_{\mathrm{N}}$ and $\mathrm{R}$ strategy, which were not obvious from the NMDS because of the non-linear or very short gradients. The R strategy was negatively associated with soil $\mathrm{P}$ in heathlands and the $\mathrm{S}$ strategy correlated negatively with soil P in grasslands.

\section{Discussion}

Our investigation of semi-natural heathlands and grasslands on a military training area in southern Germany showed that soil chemical parameters accounted for a considerable amount of the variability in species composition and richness in both habitats. This result is remarkable since within-habitat gradients in edaphic factors were short. Out of the edaphic factors examined, soil $\mathrm{pH}$ was clearly the main determinant for plant community composition and SR in heathlands, whereas grassland SR was mainly driven by soil P. Moreover, SR per plot was three times lower on average in heathlands than in grasslands harbouring more than twice as 
many plant species as the regional average (19.4 species per $25 \mathrm{~m}^{2}$ in grasslands in Bavaria (Kuhn et al. 2011)).

\section{Site conditions}

In terms of soil $\mathrm{pH}$, heathlands and grasslands were clearly separated, with strongly acidic soils in heathlands and moderately acidic to almost neutral soils in grasslands. Availability of $\mathrm{P}$ and $\mathrm{Mg}$, but not of $\mathrm{K}$, was lower in heathlands than in grasslands. According to extensive vegetation surveys reported by Klapp (1965) dating back to the beginning of the twentieth century, soil $\mathrm{P}$ concentration in heathland habitats averaged $7.0 \mathrm{mg} \mathrm{P} \mathrm{kg}^{-1}$ (P determination using the double lactate method of Egnér et al. (1960)), which is corresponding to about $3.7 \mathrm{mg}$ CAL-P kg ${ }^{-1}$ based on Steffens et al. (2010). For typical Arrhenatherum grasslands, Klapp (1965) reported average soil P concentrations of $28.4 \mathrm{mg} \mathrm{kg}^{-1}$ (corresponding to ca. $15.2 \mathrm{mg}$ CAL-P kg${ }^{-1}$ ). The P status of the soils in the present study thus agrees with the habitat characterisations derived from similar habitats about 100 years ago.

\section{Main edaphic factors influencing plant species composition and richness in heathlands}

Compared to the strong relationship between soil $\mathrm{pH}$ and plant species composition and richness in heathlands, the influence of the other soil chemical parameters examined was negligible. That soil $\mathrm{pH}$ is the driving force behind patterns of SR in heathland systems has been observed throughout different European heathland areas (De Graaf et al. 2009). In the Netherlands, heathland acidification was closely related to reduced SR and diversity, while other soil chemical parameters were less important
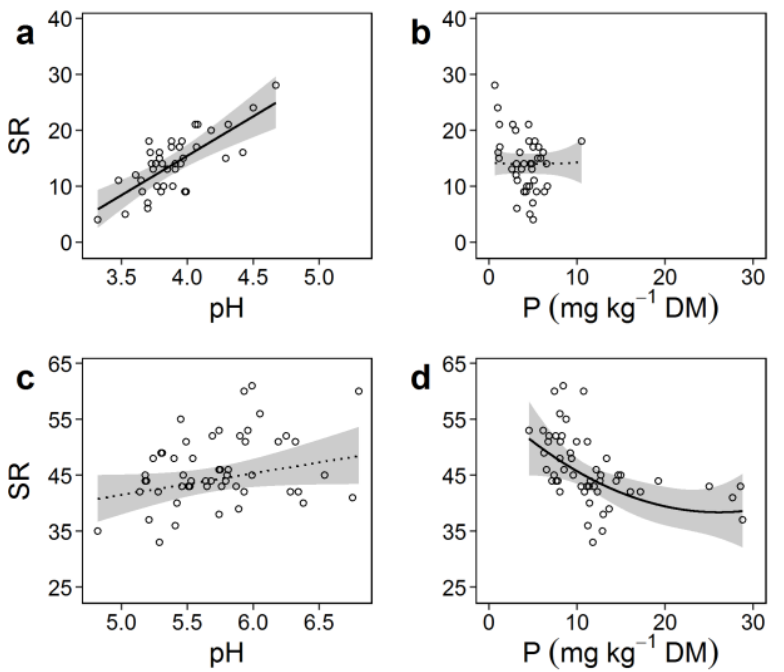

Figure 2: Relationships between vascular plant species richness (SR) and soil $\mathrm{pH}$ in (a) heathlands and (c) grasslands and between plant SR and soil P concentration in (b) heathlands and (d) grasslands, Grafenwöhr military training area (GTA) in Bavaria, Germany. Lines and ribbons show the predictions ( $\pm 95 \%$ confidence interval) based on modelaveraged coefficient estimates along the range of observed $\mathrm{pH}$ or $\mathrm{P}$ values when all other model parameters were held constant at their mean. Solid and dotted lines indicate strongly (i.e. 95\% confidence interval does not include zero) and weakly supported effects (cf. Table 3), respectively. Circles represent observations. 
Table 4: Pearson correlation coefficients ( $r$ ) between species richness (SR) and Ellenberg indicator values (EIV) or CSR-signature components ( $E_{F}$, EIV for soil moisture; $E_{R}$, EIV for soil reaction; $\mathrm{E}_{\mathrm{N}}$, EIV for productivity; R strategy, ruderal; S strategy, stress-tolerator; C strategy, competitor) and between soil phosphorus (P) and CSR-signature components in heathlands and grasslands, Grafenwöhr military training area (GTA) in Bavaria, Germany.

\begin{tabular}{|c|c|c|c|c|c|}
\hline \multirow[b]{2}{*}{ Parameter 1} & \multirow[b]{2}{*}{ Parameter 2} & \multicolumn{2}{|c|}{ Heathlands } & \multicolumn{2}{|c|}{ Grasslands } \\
\hline & & $r$ & $p^{a}$ & $r$ & $p^{a}$ \\
\hline SR & $\mathrm{E}_{\mathrm{N}}$ & 0.48 & 0.002 & 0.28 & 0.043 \\
\hline SR & $\mathrm{E}_{\mathrm{F}}$ & 0.39 & 0.013 & -0.51 & $<0.001$ \\
\hline SR & $\mathrm{E}_{\mathrm{R}}$ & 0.47 & 0.002 & 0.34 & 0.013 \\
\hline SR & C strategy & -0.28 & 0.080 & 0.30 & 0.029 \\
\hline SR & S strategy & 0.19 & 0.232 & 0.06 & 0.652 \\
\hline SR & R strategy & 0.32 & 0.043 & -0.41 & 0.002 \\
\hline $\mathrm{P}$ & C strategy & 0.03 & 0.858 & 0.18 & 0.188 \\
\hline $\mathrm{P}$ & S strategy & 0.12 & 0.446 & -0.37 & 0.006 \\
\hline $\mathrm{P}$ & R strategy & -0.39 & 0.012 & 0.11 & 0.435 \\
\hline
\end{tabular}

${ }^{a}$ Bold type face indicates statistical significance $(p<0.05)$

(Roem et al. 2002). A serious problem from the conservationist point of view is that endangered species disappear in soils at $\mathrm{pH}_{(\mathrm{H} 2 \mathrm{O})}<5$ (Roem and Berendse 2000; Van Den Berg et al. 2005).

Contrasting the $\mathrm{pH}$ effects on SR in heathlands and in grasslands (for which evidence was limited; Table 3; Figure 2(a,c)) revealed that the vegetation responded more strongly to a one unit change in $\mathrm{pH}$ in the acidic than in the rather neutral $\mathrm{pH}$ range, which can be attributed to the logarithmic character of the $\mathrm{pH}$ scale. Although $\mathrm{pH}$ does not have a limiting effect on plants per se, it alters nutrient availability (Roem and Berendse 2000). For example, the solubility of soil $\mathrm{P}$ and its availability to plants depend on $\mathrm{pH}$ (Barrow 2017). The effectiveness of methods measuring extractable soil $\mathrm{P}$ as indicator for plant-available $\mathrm{P}$, however, may itself be influenced by $\mathrm{pH}$ (Holford 1997; Wuenscher et al. 2015). The CAL-method used for $\mathrm{P}$ extraction in the present study is known for potentially underestimating the actual plant-available P in acidic soils (Schüller 1969; Wuenscher et al. 2015). The observed negative correlation between $\mathrm{pH}$ and soil $\mathrm{P}$ in heathlands thus might have been less pronounced if the soil test method employed was unbiased by $\mathrm{pH}$. Even more important in terms of SR is that reduced $\mathrm{pH}$ induces toxic effects of aluminium (Van Den Berg et al. 2005) and ammonium (Rout et al. 2001; Roem et al. 2002). Only few plant species, such as Calluna vulgaris (De Graaf et al. 1997) or Deschampsia flexuosa (Van Den Berg et al. 2005), can tolerate these toxic conditions and persist under extreme soil acidity. In the NMDS ordination, these acidophilous species were located in the left part of the ordination space associated with reduced $\mathrm{pH}$ and SR, whereas basidophilous species sensitive to aluminium toxicity (characterised by 
$\mathrm{E}_{\mathrm{R}}>6$ (Ewald 2003)), such as Lotus corniculatus or Linum catharticum, were located in the right part of the ordination space (Figures 1, S2).

We found no evidence that soil CAL-P affected heathland plant SR (Figure 2(b)), which might also be related to the short soil $\mathrm{P}$ gradient in this habitat type (ranging from 0.7 to $10.5 \mathrm{mg} \mathrm{kg}^{-1}$ ). Consequently, we cannot support our Hypothesis (1) that $\mathrm{P}$ can have a positive effect on plant SR when P availability is low.

\section{Main edaphic factors influencing plant species composition and richness in grasslands}

Soil $\mathrm{pH}$ and the concentrations of $\mathrm{Mg}$ and $\mathrm{P}$ influenced grassland species composition (Table 2 and Figure 1). While the significant effects of soil $\mathrm{pH}$ and $\mathrm{Mg}$ became obvious in the two-dimensional NMDS ordination, the effect of $\mathrm{P}$ on grassland species composition was only revealed by the direct analysis of the distance matrix in PerMANOVA.

Grassland SR, however, did not significantly respond to any factor but soil P. We know about the adverse effect of enhanced $\mathrm{P}$ availability on grassland diversity from studies in intensively used and semi-natural areas and also from fertilisation experiments (Crawley et al. 2005; Hejcman et al. 2010). The present study allows expanding our knowledge on agriculturally unimproved areas with inherently low $\mathrm{P}$ availability. Since the various approaches to determine plant-available P applied in current research assess different $\mathrm{P}$ pools and are differently affected by soil properties, such as $\mathrm{pH}$, carbonate content or texture, they can highly differ in extraction yield (Wuenscher et al. 2015). To facilitate the comparison between studies, we used a conversion factor of 1.45 (based on Barberis et al. 1995; Wuenscher et al. 2015) to provide approximate values converted from Olsen-P to CAL-P. Regarding lowland hay meadows across Europe, Ceulemans et al. (2014) identified a log-linear decrease of SR with increasing soil P up to Olsen-P of $124 \mathrm{mg} \mathrm{kg}^{-1}$ (ca. $180 \mathrm{mg}$ CAL-P kg${ }^{-1}$ ), above which plant diversity remained at a constantly low level. This threshold is about six times higher than the maximum CAL-P concentration we observed in grasslands. Olsen-P concentrations $>15 \mathrm{mg} \mathrm{l}^{-1}$ (ca. $30 \mathrm{mg}$ CAL-P kg${ }^{-1}$ assuming a bulk density of $1.4 \mathrm{~g} \mathrm{~cm}^{-3}$ ) are considered as an indication of anthropogenic P enrichment (Critchley et al. 2002), whereas the highest chance for the restoration of species-rich grasslands is anticipated where Olsen-P concentrations do not exceed $10 \mathrm{mg} \mathrm{kg}^{-1}$ (ca. $14.5 \mathrm{mg}$ CAL-P kg${ }^{-1}$; (Gilbert et al. 2009)). Our study shows that even slight increases in soil $\mathrm{P}$ are associated with a reduction of SR in low-P-level grasslands, underlining not only the potential nature conservation value of historically unimproved grasslands but also their susceptibility to any increase in nutrient status. We could not confirm our Hypothesis (1) that plant diversity might be limited by extremely low $\mathrm{P}$ availability in grasslands. While we did not detect any significant relationship between plant SR and soil P (ranging from 0.7 to $10.5 \mathrm{mg} \mathrm{CAL-P} \mathrm{kg}{ }^{-1}$ ) in heathlands, the relationship was negative in grasslands, where CAL-extractable P was higher (ranging from 4.6 to $28.8 \mathrm{mg} \mathrm{kg}^{-1}$ ) There was no evidence for a hump-shaped relationship between SR and soil P. This is in contrast with different reports of plant SR peaking along the $\mathrm{P}$ availability gradient (Table S1). Combining our results from heathlands and grasslands suggests that the effect of $\mathrm{P}$ at the within-habitat scale depends on the habitat type: while SR in 
heathlands was not influenced by soil $\mathrm{P}$, grasslands exhibited a substantial decrease in SR with increasing P. Alarmingly, grassland SR decreased most steeply with increasing $\mathrm{P}$ at the lower end of the soil $\mathrm{P}$ range studied.

While $\mathrm{pH}$ could explain a higher share of the variation in grassland species composition than the other edaphic factors examined, we found only minor evidence for a slightly positive relationship between $\mathrm{pH}$ and grassland SR. Previous studies reported inconsistent results on the importance of soil $\mathrm{pH}$ for grassland diversity. Janssens et al. (1998) did not find a clear relationship between $\mathrm{pH}$ and SR in grasslands and attributed this to the influence of $\mathrm{pH}$ on nutrient availability. Ceulemans et al. (2013) documented a weak positive relationship between $\mathrm{pH}$ and grassland SR, as well as Critchley et al. (2002), but the latter underlined that in mesotrophic grasslands SR did not depend on soil $\mathrm{pH}$. They supposed that $\mathrm{pH}$ was more important for explaining differences in SR between broader vegetation types than between subunits within one vegetation type, which is in accord with the heathlands (low SR) vs. grasslands (high SR) dichotomy in the present study.

\section{Additional soil-vegetation relationships}

Our results did not support pronounced relationships between soil $\mathrm{Mg}$ or $\mathrm{K}$ concentration and SR in neither heathlands nor grasslands. Similarly, from grasslands in British Environmentally Sensitive Areas, only weak relationships between soilextractable $\mathrm{K}$ and $\mathrm{Mg}$ concentrations and SR are reported (Critchley et al. 2002). Grassland species composition, however, was affected by Mg (Table 2, Figure 1(b)). In the ordination of grassland plots, the directional trends of both $\mathrm{pH}$ and $\mathrm{Mg}$ pointed in the same direction, which might relate to the reduced $\mathrm{Mg}$ uptake in plants under acidic conditions (Mayland and Wilkinson 1989). That Mg can have a considerable impact on grassland species composition, but not necessarily on SR, was shown by a long-term fertilisation experiment as well (Hejcman et al. 2010). In heathlands, we did not observe a significant $\mathrm{Mg}$ effect on species composition nor a similar coincidence of increasing $\mathrm{pH}$ and $\mathrm{Mg}$, probably due to the low variation in heathland soil $\mathrm{Mg}$ concentration.

Regarding soil K, we did not find distinct relationships with species composition or richness. The average $\mathrm{K}$ concentration in the present study was about six times lower than the threshold of $300 \mathrm{mg} \mathrm{K} \mathrm{kg}{ }^{-1}$ dry soil above which a decrease in SR can be expected (Janssens et al. 1998). To the observation that high grassland diversity is compatible with moderately high soil K (Janssens et al. 1998; Marini et al. 2007), we can hence add that under zero-input conditions, an increase in $\mathrm{K}$ from low (minimum ca. $20 \mathrm{mg}$ CAL- $\mathrm{K} \mathrm{kg}^{-1}$; cf. Table 1) to intermediate levels (maximum ca. $85 \mathrm{mg}$ CAL-K $\mathrm{kg}^{-1}$ ) does not affect plant SR in open habitats.

\section{Functional gradients in species composition}

We employed EIV and Grime's functional strategy types as vegetation-derived indicators to identify environmental and functional gradients in heathland and grassland communities. In particular, for lack of a soil test method for plant-available $\mathrm{N}$ reliable at low levels of available N (Schimel and Bennett 2004), we made use of $\mathrm{E}_{\mathrm{N}}$, which is regarded as an integrative indicator for overall soil fertility and resulting 
productivity (Schaffers and Sýkora 2000). Böcker et al. (1983) defined mean EIV for southern German plant communities described by Oberdorfer (1957). In comparison with these literature values for hay meadows (Arrhenatherion, $\mathrm{E}_{\mathrm{F}}: 5.2, \mathrm{E}_{\mathrm{R}}: 5.8, \mathrm{E}_{\mathrm{N}}: 4.3$ ), the mean EIV of the plots we surveyed in grasslands were equal for $\mathrm{E}_{\mathrm{F}}$, slightly lower for $E_{R}$ and markedly lower for $E_{N}$. For the mean $E_{R}$ and $E_{N}$ of the heathland plots, the differences to the mean values of southern German dry heaths (CallunoVacinietum, $\left.\mathrm{E}_{\mathrm{F}}: 5.2, \mathrm{E}_{\mathrm{R}}: 2.4, \mathrm{E}_{\mathrm{N}}: 2.6\right)$ were even more pronounced. Since several studies have found a long-term increase in $\mathrm{E}_{\mathrm{N}}$ for grasslands (Haines-Young et al. 2003; Bennie et al. 2006; Duprè et al. 2010; Wesche et al. 2012), we would rather have expected an increase in $\mathrm{E}_{\mathrm{N}}$ given the time lag between the surveys of Oberdorfer (1957) and the present study. Therefore, we can assume that nutrient enrichment from atmospheric deposition (modelled as $11-13 \mathrm{~kg} \mathrm{~N} \mathrm{ha}^{-1}$ at GTA in 2009 (Umweltbundesamt 2011; Kruit et al. 2014)) probably has not much affected vegetation communities on GTA during the last decades. However, even though the modelled annual $\mathrm{N}$ deposition for GTA is less than the average European $\mathrm{N}$ deposition of $17 \mathrm{~kg} \mathrm{ha}^{-1}$ (Stevens et al. 2004), and is below the critical load for low and medium altitude hay meadows $\left(20-30 \mathrm{~kg} \mathrm{~N}^{-1} \mathrm{year}^{-1}\right.$; Bobbink and Hettelingh (2011)), it already falls into the critical load range of $\mathrm{N}$ deposition for dry heaths (10$20 \mathrm{~kg} \mathrm{~N} \mathrm{ha}{ }^{-1}$ year $\left.^{-1}\right)$. Considering the complex and long-term impacts of increased $\mathrm{N}$ inputs to dry heaths (Härdtle et al. 2009; Bobbink and Hettelingh 2011; Fagúndez 2012; Southon et al. 2013), paying attention to further $\mathrm{N}$ deposition in this habitat is recommended, especially since critical $\mathrm{N}$ load ranges have recently been criticised for being too high to prevent significant $\mathrm{N}$ deposition-induced community compositional change (Wilkins et al. 2016).

Interestingly, in our study $\mathrm{E}_{\mathrm{N}}$ and soil $\mathrm{P}$ did not correlate (heathlands: Pearson $r=-0.02, p=0.924$; grasslands: Pearson $r=0.20, p=0.142$; but see Chytrỳ et al. (2009)), requiring to consider the general soil fertility as reflected by the plant community separately from the concentration of $\mathrm{P}$ as a single soil nutrient. In contrast to the negative relationship between soil $\mathrm{P}$ and SR, it appeared from ordination and correlation test results that elevated $\mathrm{SR}$ and increased $\mathrm{E}_{\mathrm{N}}$ co-occurred in grasslands (Table 4). As expected in our second hypothesis and in line with Critchley et al. (2002), we found that soil P and the S strategy component were negatively associated in grasslands, while a direct correlation between $\mathrm{S}$ strategy and SR was missing (Table 4). Hence, a loss of stress-tolerant plants is not sufficient to explain the reduced SR in P-rich plots. In contrast to the finding by Marini et al. (2007), elevated SR was associated with an increased share of the C strategy and a reduced share of the R strategy. Plants with high competitive ability can exploit resources effectively under low levels of stress and disturbance, whereas ruderal plants are mostly short-lived species whose seedling establishment depends on disturbances (Grime 1979). The disturbance regime on GTA, characterised by military training and wildlife activities, might provide favourable conditions for ruderal plants, while increasing general soil fertility, as reflected by $\mathrm{E}_{\mathrm{N}}$, could additionally allow the occurrence of plants with higher competitive ability. That $\mathrm{E}_{\mathrm{F}}$ and SR were negatively correlated might be explained by soils with higher moisture content being potentially more susceptible to disturbances. Overall, we can support 
what Warren et al. (2007) have proposed, i.e. that, owing to the spatially and temporally heterogeneous disturbance regime, military training areas can provide suitable habitat for the whole continuum of species ranging from disturbancedependent to disturbance-averse.

While we showed that soil $\mathrm{P}$ is not a main factor for heathland plant diversity (e.g. Figure 2), similar to the pattern in grasslands, $\mathrm{SR}$ and $\mathrm{E}_{\mathrm{N}}$ were also positively correlated in heathlands (Table 4), suggesting that slight increases in productivity did not compromise SR in dry heaths. This result agrees with a British survey on the effects of $\mathrm{N}$ deposition stating that in plant communities of acid soils, a reduction in richness did not result from competitive exclusion caused by the response of fastgrowing dominants to increased nutrient availability but from soil acidification (Maskell et al. 2010). $\mathrm{E}_{\mathrm{F}}$ in heathlands reflected their broader range of soil moisture conditions compared to grasslands and correlated positively with heathland SR, suggesting that also water availability could potentially affect heathland plant diversity. Regarding the CSR-strategy components, only the R strategy exhibited a significant (non-linear) trend in the ordination and correlated positively with soil $\mathrm{P}$ and SR (Table 4), but its gradient length was minimal. Hence, increasing soil P in heathlands did not appear to be related to a decrease in stress-tolerant plants nor to an increase in plants with competitive strategy. In heathlands, we thus did not find evidence to confirm a relation between soil $\mathrm{P}$ and the distribution of plant functional strategy types as supposed in Hypothesis (2).

\section{Conclusions}

We found no support for the existence of a unimodal relationship between soil $\mathrm{P}$ and SR at the scale of single open habitat types. Despite the long-term absence of common agricultural management (including fertilisation) and soil P concentrations ranging much lower relative to comparable studies (Table S1), the well-documented negative relationship between soil P and grassland SR was confirmed, whereas in heathlands evidence for any effect of $\mathrm{P}$ was lacking. We assume that even though CAL-extractable $\mathrm{P}$ in heathlands ranged as low as $<1 \mathrm{mg} \mathrm{kg}^{-1}$, this concentration still met the basic requirements of plant species. It has to be kept in mind, however, that heathlands, as opposed to grasslands, were governed by strong soil acidity and harboured less than half the number of species. Hence, it remains for further studies to explore how low-level soil P relates to SR within less acidified heathland habitats or acidic grasslands.

Important practical implications arise from our investigation: based on the detrimental influence of reduced $\mathrm{pH}$ on heathland plant species, we suggest that future efforts for heathland conservation should be mindful of the potential species loss caused by further acidification (e.g. resulting from $\mathrm{N}$ deposition). Aiming at preserving species-rich grasslands, it seems most essential to keep soil $\mathrm{P}$ at a low level. Our comprehensive results from a long-term zero-input area may prove valuable as a reference to evaluate changes in soil-vegetation relationships in open habitats driven by the past 100 years of agricultural intensification. 


\section{Acknowledgements}

We thank the Federal Forests Division (Bundesforst) of the German Institute for Federal Real Estate (Bundesanstalt für Immobilienaufgaben) and the Institut für Wildbiologie Göttingen und Dresden e.V. for close cooperation and support. The project was supported by funds of German government's Special Purpose Fund held at Landwirtschaftliche Rentenbank [28 RZ 7007].

\section{References}

Anderson MJ. 2001. A new method for non-parametric multivariate analysis of variance. Austral Ecology. 26:32-46.

Barberis E, Marsan FA, Scalenghe R, Lammers A, Schwertmann U, Edwards AC, Maguire R, Wilson MJ, Delgado A, Torrent J. 1995. European soils overfertilized with phosphorus: part 1. Basic properties. Fertilizer Research. 45:199-207.

Barrow NJ. 2017. The effects of $\mathrm{pH}$ on phosphate uptake from the soil. Plant and soil. 410:401-410.

Barton K 2016. MuMIn: Multi-Model Inference. R package version 1.15.6 [Internet]. [accessed 2016 Jan 14] http:/ / CRAN.R-project.org/package=MuMIn

Bennie J, Hill MO, Baxter R, Huntley B. 2006. Influence of slope and aspect on long-term vegetation change in British chalk grasslands. Journal of Ecology. 94:355-368.

Bobbink R, Hettelingh J-P. 2011. Review and revision of empirical critical loads and dose-response relationships: proceedings of an expert workshop, Noordwijkerhout, 23-25 June 2010 [Internet]. Bilthoven, NL: Rijksinstituut voor Volksgezondheid en Milieu RIVM; [accessed 2017 Sep 21]. http:/ / rivm.openrepository.com/rivm/handle/ 10029/260510

Bobbink R, Hicks K, Galloway J, Spranger T, Alkemade R, Ashmore M, Bustamante M, Cinderby S, Davidson E, Dentener F, et al. 2010. Global assessment of nitrogen deposition effects on terrestrial plant diversity: a synthesis. Ecological Applications. 20:30-59.

Böcker R, Kowarik I, Bornkamm R. 1983. Untersuchungen zur Anwendung der Zeigerwerte nach Ellenberg. Verhandlungen der Gesellschaft für Ökologie. 11:35-56.

Bundesanstalt für Immobilienaufgaben. 2003. Standortskarte Liegenschaft Grafenwöhr. Bonn, DE: Bundesanstalt für Immobilienaufgaben - Sparte Bundesforst.

Burnham KP, Anderson DR. 2002. Model selection and multimodel inference: a practical information-theoretic approach. New York, NY, US: Springer.

Ceulemans T, Merckx R, Hens M, Honnay O. 2013. Plant species loss from European semi-natural grasslands following nutrient enrichment - is it nitrogen or is it phosphorus?. Global Ecology and Biogeography. 22:73-82.

Ceulemans T, Stevens CJ, Duchateau L, Jacquemyn H, Gowing DJG, Merckx R, Wallace H, Van Rooijen N, Goethem T, Bobbink R, et al. 2014. Soil phosphorus constrains biodiversity across European grasslands. Global Change Biology. 20:3814-3822.

Chytrỳ M, Hejcman M, Hennekens SM, Schellberg J. 2009. Changes in vegetation types and Ellenberg indicator values after 65 years of fertilizer application in the Rengen Grassland Experiment, Germany. Applied Vegetation Science. 12:167-176.

Cizek O, Vrba P, Benes J, Hrazsky Z, Koptik J, Kucera T, Marhoul P, Zamecnik J, Konvicka M. 2013. Conservation potential of abandoned military areas matches that of established reserves: plants and butterflies in the Czech Republic. PloS one. 8:e53124.

Crawley MJ, Johnston AE, Silvertown J, Dodd M, De Mazancourt C, Heard MS, Henman DF, Edwards GR, Huisman AEJ. 2005. Determinants of species richness in the Park Grass Experiment. The American Naturalist. 165:179-192.

Critchley CNR, Chambers BJ, Fowbert JA, Bhogal A, Rose SC, Sanderson RA. 2002. Plant species richness, functional type and soil properties of grasslands and allied vegetation in English Environmentally Sensitive Areas. Grass and Forage Science. 57:82-92.

Cross AF, Schlesinger WH. 1995. A literature review and evaluation of the Hedley fractionation: applications to the biogeochemical cycle of soil phosphorus in natural ecosystems. Geoderma. 64:197-214. 
De Graaf MCC, Bobbink R, Verbeek PJM, Roleofs JGM. 1997. Aluminium toxicity and tolerance in three heathland species. Water, Air, and Soil Pollution. 98:229-239.

De Keersmaeker L, Martens L, Verheyen K, Hermy M, De Schrijver A, Lust N. 2004. Impact of soil fertility and insolation on diversity of herbaceous woodland species colonizing afforestations in Muizen forest (Belgium). Forest Ecology and Management. 188:291-304.

Dormann CF, Elith J, Bacher S, Buchmann C, Carl G, Carré G, Marquéz JRG, Gruber B, Lafourcade B, Leitão PJ, et al.. 2013. Collinearity: a review of methods to deal with it and a simulation study evaluating their performance. Ecography. 36:27-46.

Dorrough J, Moxham C, Turner V, Sutter G. 2006. Soil phosphorus and tree cover modify the effects of livestock grazing on plant species richness in Australian grassy woodland. Biological Conservation. 130:394-405.

Dumortier M, Butaye J, Jacquemyn H, Van Camp N, Lust N, Hermy M. 2002. Predicting vascular plant species richness of fragmented forests in agricultural landscapes in central Belgium. Forest Ecology and Management. 158:85-102.

Duprè C, Stevens CJ, Ranke T, Bleeker A, Peppler-Lisbach C, Gowing DJG, Dise NB, Dorland E, Bobbink R, Diekmann M. 2010. Changes in species richness and composition in European acidic grasslands over the past 70 years: the contribution of cumulative atmospheric nitrogen deposition. Global Change Biology. 16:344-357.

Egnér H, Riehm H, Domingo WR. 1960. Untersuchungen über die chemische Bodenanalyse als Grundlage für die Beurteilung des Nährstoffzustandes der Böden. II. Chemische Extraktionsmethoden zur Phosphor-und Kaliumbestimmung. Kungliga Lantbrukshögskolans Annaler. 26:199-215.

Ellenberg H, Leuschner C. 2010. Vegetation Mitteleuropas mit den Alpen. Stuttgart, DE: UTB Ulmer.

European Environment Agency. 2015. EU 2010 biodiversity baseline - adapted to the MAES typology. Luxembourg: Publications Office of the European Union.

Ewald J. 2003. The calcareous riddle: why are there so many calciphilous species in the Central European flora?. Folia Geobotanica. 38:357-366.

Fagúndez J. 2012. Heathlands confronting global change: drivers of biodiversity loss from past to future scenarios. Annals of Botany. 111:151-172.

Field CD, Dise NB, Payne RJ, Britton AJ, Emmett BA, Helliwell RC, Hughes S, Jones L, Lees S, Leake JR, et al.. 2014. The role of nitrogen deposition in widespread plant community change across semi-natural habitats. Ecosystems. 17:864-877.

Fraser LH, Pither J, Jentsch A, Sternberg M, Zobel M, Askarizadeh D, Bartha S, Beierkuhnlein C, Bennett JA, Bittel A, et al.. 2015. Worldwide evidence of a unimodal relationship between productivity and plant species richness. Science. 349:302-305.

Gilbert J, Gowing D, Wallace H. 2009. Available soil phosphorus in semi-natural grasslands: assessment methods and community tolerances. Biological Conservation. 142:1074-1083.

Grime JP. 1979. Plant strategies and vegetation processes. Chichester, UK: Wiley.

Grueber CE, Nakagawa S, Laws RJ, Jamieson IG. 2011. Multimodel inference in ecology and evolution: challenges and solutions. Journal of Evolutionary Biology. 24:699-711.

Haines-Young R, Barr CJ, Firbank LG, Furse M, Howard DC, McGowan G, Petit S, Smart SM, Watkins JW. 2003. Changing landscapes, habitats and vegetation diversity across Great Britain. Journal of Environmental Management. 67:267-281.

Härdtle W, Von Oheimb G, Gerke A-K, Niemeyer M, Niemeyer T, Assmann T, Drees C, Matern A, Meyer H. 2009. Shifts in N and P budgets of heathland ecosystems: effects of management and atmospheric inputs. Ecosystems. 12:298-310.

Hautier Y, Niklaus PA, Hector A. 2009. Competition for light causes plant biodiversity loss after eutrophication. Science. 324:636-638.

Hejcman M, Češková M, Schellberg J, Pätzold S. 2010. The Rengen Grassland Experiment: effect of soil chemical properties on biomass production, plant species composition and species richness. Folia Geobotanica. 45:125-142.

Hodgson JG, Grime JP, Wilson PJ, Thompson K, Band SR. 2005. The impacts of agricultural change (1963-2003) on the grassland flora of Central England: processes and prospects. Basic and Applied Ecology. 6:107-118.

Hoffmann G. 1991. Methodenbuch Band 1, Die Untersuchung von Böden. Darmstadt, DE: VDLUFA-Verlag. 
Holford ICR. 1997. Soil phosphorus: its measurement, and its uptake by plants. Soil Research. 35:227-240.

Hunt R, Hodgson JG, Thompson K, Bungener P, Dunnett NP, Askew AP. 2004. A new practical tool for deriving a functional signature for herbaceous vegetation. Applied Vegetation Science. $7: 163-170$

Jäger EJ. 2011. Rothmaler - Exkursionsflora von Deutschland: Gefäßpflanzen: Grundband. Heidelberg, DE: Spektrum Akademischer Verlag.

Janssens F, Peeters A, Tallowin JRB, Bakker JP, Bekker RM, Fillat F, Oomes MJM. 1998. Relationship between soil chemical factors and grassland diversity. Plant and Soil. 202:69-78.

Klapp E. 1965. Grünlandvegetation und Standort nach Beispielen aus West-, Mittel-, und Süddeutschland. Berlin, DE: Paul Parey.

Kruit RW, Schaap M, Segers A, Heslinga D, Builtjes P, Banzhaf S, Scheuschner T. 2014. Modelling and mapping of atmospheric nitrogen and sulphur deposition and critical loads for ecosystem specific assessment of threats to biodiversity in Germany - PINETI (Pollutant INput and Ecosys'Tem Impact) Substudy Report 1. Dessau-Roßlau, DE: Umweltbundesamt.

Kuhn G, Heinz S, Mayer F. 2011. Grünlandmonitoring Bayern: Ersterhebung der Vegetation 20022008, 1st ed. Freising, DE: Bayerische Landesanstalt für Landwirtschaft (LfL).

Lang A, Zintl R. 2010. Kartieranleitung Biotopkartierung Bayern Teil 2: Biotoptypen inklusive der Offenland-Lebensraumtypen der Fauna-Flora-Habitat-Richtlinie (Flachland/Städte) [Internet]. Augsburg: Bayerisches Landesamt für Umwelt, editor; [cited 2017 Jun 8]. https://www.lfu.bayern.de/natur/biotopkartierung_ausser halb_alpen/kartieranleitungen/doc/biotoptypen_teil2.pdf

LUFA Nord-West. 2017. Grundnährstoffe : Landwirtschaftliche Untersuchungs- und Forschungsanstalt Nord-West [Internet]. [accessed 2017 Jun 7]. http://www.lufa-nord-west. $\mathrm{de} /$ index.cfm/nav/3/article/470.html

MacDonald GK, Bennett EM, Taranu ZE. 2012. The influence of time, soil characteristics, and landuse history on soil phosphorus legacies: a global meta-analysis. Global Change Biology. 18:1904-1917.

Marini L, Scotton M, Klimek S, Isselstein J, Pecile A. 2007. Effects of local factors on plant species richness and composition of Alpine meadows. Agriculture, Ecosystems \& Environment. 119:281-288

Maskell LC, Smart SM, Bullock JM, Thompson K, Stevens CJ. 2010. Nitrogen deposition causes widespread loss of species richness in British habitats. Global Change Biology. 16:671-679.

Mayland HF, Wilkinson SR. 1989. Soil factors affecting magnesium availability in plant-animal systems: a review. Journal of Animal Science. 67:3437-3444.

De Graaf MCC, Bobbink R, Smits NAC, Van Diggelen R, Roelofs JGM. 2009. Biodiversity, vegetation gradients and key biogeochemical processes in the heathland landscape. Biological Conservation. 142:2191-2201.

Minchin PR. 1987. An evaluation of the relative robustness of techniques for ecological ordination. Vegetatio. 69:89-107. Mucina L, Bültmann H, Dierßen K, Theurillat J-P, Raus T, Čarni A, Šumberová K, Willner W, Dengler J, García RG, et al.. 2016. Vegetation of Europe: hierarchical floristic classification system of vascular plant, bryophyte, lichen, and algal communities. Applied Vegetation Science. 19:3-264.

Nakagawa S, Schielzeth H. 2013. A general and simple method for obtaining $\mathrm{R}^{2}$ from generalized linear mixed-effects models. Methods in Ecology and Evolution. 4:133-142.

Oberdorfer E. 1957. Süddeutsche Pflanzengesellschaften. Jena, DE: Gustav Fischer Verlag.

Oksanen J, Blanchet FG, Kindt R, Legendre P, Minchin PR, O’Hara RB, Simpson GL, Solymos P, Stevens MHH, Wagner H 2015. Vegan: community ecology package. R package version 2.31 [Internet]. [accessed 2016 Jan 14] http://CRAN.R-project.org/package=vegan

Pinheiro J, Bates D, DebRoy S, Sarkar D, R Core Team R. 2015. nlme: linear and nonlinear mixed effects models. R package version 3.1-131 [Internet]. [accessed 2016 Jan 14] http://CRAN.R-project.org/package=nlme

R Core Team. 2015. R: A language and environment for statistical computing [Internet]. Vienna, AT: R Foundation for Statistical Computing. [cited 2016 Jan 14]. Available from: https://www.Rproject.org/

Rennwald E. 2000. Verzeichnis und Rote Liste der Pflanzengesellschaften Deutschlands. Schriftenreihe für Vegetationskunde. 35:1-800. 
Roem WJ, Berendse F. 2000. Soil acidity and nutrient supply ratio as possible factors determining changes in plant species diversity in grassland and heathland communities. Biological Conservation. 92:151-161.

Roem WJ, Klees H, Berendse F. 2002. Effects of nutrient addition and acidification on plant species diversity and seed germination in heathland. Journal of Applied Ecology. 39:937-948.

Rout GR, Samantaray S, Das P. 2001. Aluminium toxicity in plants: a review. Agronomy for Sustainable Development. 21:3-21.

Schaffers AP, Sýkora KV. 2000. Reliability of Ellenberg indicator values for moisture, nitrogen and soil reaction: a comparison with field measurements. Journal of Vegetation Science. 11:225244.

Schelfhout S, De Schrijver A, De Bolle S, De Gelder L, Demey A, Du Pré T, De Neve S, Haesaert G, Verheyen K, Mertens J. 2015. Phosphorus mining for ecological restoration on former agricultural land. Restoration Ecology. 23:842-851.

Schimel JP, Bennett J. 2004. Nitrogen mineralization: challenges of a changing paradigm. Ecology. 85:591-602.

Schüller H. 1969. Die CAL-Methode, eine neue Methode zur Bestimmung des pflanzenverfügbaren Phosphates in Böden. Zeitschrift für Pflanzenernährung und Bodenkunde. 123:48-63.

Smil V. 2000. Phosphorus in the environment: natural flows and human interferences. Annual review of energy and the environment. 25:53-88.

Soons MB, Hefting MM, Dorland E, Lamers LPM, Versteeg C, Bobbink R. 2017. Nitrogen effects on plant species richness in herbaceous communities are more widespread and stronger than those of phosphorus. Biological Conservation. 212:390-397.

Southon GE, Field C, Caporn SJM, Britton AJ, Power SA. 2013. Nitrogen deposition reduces plant diversity and alters ecosystem functioning: field-scale evidence from a nationwide survey of UK heathlands. PLoS ONE. 8:e59031.

Steffens D, Leppin T, Luschin-Ebengreuth N, Min Yang Z, Schubert S. 2010. Organic soil phosphorus considerably contributes to plant nutrition but is neglected by routine soiltesting methods. Journal of Plant Nutrition and Soil Science. 173:765-771.

Stevens CJ, Dise NB, Mountford JO, Gowing DJ. 2004. Impact of nitrogen deposition on the species richness of Grasslands. Science. 303:1876-1879.

Stewart JWB, Tiessen H. 1987. Dynamics of soil organic phosphorus. Biogeochemistry. 4:41-60.

Tang Z, Deng L, An H, Yan W, Shangguan Z. 2017. The effect of nitrogen addition on community structure and productivity in grasslands: a meta-analysis. Ecological Engineering. 99:31-38.

Tilman D. 1982. Resource competition and community structure. Princeton, NJ, US: Princeton University Press.

Tunney H, Csath P, Ehlert P. 2003. Approaches to calculating P balance at the field-scale in Europe. Journal of Plant Nutrition and Soil Science. 166:438-446.

Umweltbundesamt. 2011. Hintergrundbelastungsdaten Stickstoff - Bezugsjahr 2009 [Internet]. [cited 2017 Jun 21]. Available from: http://gis.uba.de/website/depo1/

Van Den Berg LJL, Dorland E, Vergeer P, Hart MAC, Bobbink R, Roelofs JGM. 2005. Decline of acid-sensitive plant species in heathland can be attributed to ammonium toxicity in combination with low pH. New Phytologist. 166:551-564.

Virtanen R, Oksanen J, Oksanen L, Razzhivin VY. 2006. Broadscale vegetation-environment relationships in Eurasian high latitude areas. Journal of Vegetation Science. 17:519-528.

Wagenmakers E-J, Farrell S. 2004. AIC model selection using Akaike weights. Psychonomic Bulletin \& Review. 11:192-196.

Warren SD, Büttner R. 2008a. Active military training areas as refugia for disturbance-dependent endangered insects. Journal of Insect Conservation. 12:671-676.

Warren SD, Büttner R. 2008b. Relationship of endangered amphibians to landscape disturbance. The Journal of Wildlife Management. 72:738-744.

Warren SD, Holbrook SW, Dale DA, Whelan NL, Elyn M, Grimm W, Jentsch A. 2007. Biodiversity and the heterogeneous disturbance regime on military training lands. Restoration Ecology. 15:606-612.

Wassen MJ, Venterink HO, Lapshina ED, Tanneberger F. 2005. Endangered plants persist under phosphorus limitation. Nature. 437:547-550. 
Wesche K, Krause B, Culmsee H, Leuschner C. 2012. Fifty years of change in Central European grassland vegetation: large losses in species richness and animal-pollinated plants. Biological Conservation. 150:76-85.

Wilkins K, Aherne J, Bleasdale A. 2016. Vegetation community change points suggest that critical loads of nutrient nitrogen may be too high. Atmospheric Environment. 146:324-331.

Wood S 2016. Package 'mgcv' - mixed GAM computation vehicle with GCV/AIC/REML smoothness estimation. R package version 1. 8-12[Internet]. [accessed 2016 May 9] http://cran.uib.no/web/packages/mgcv/mgcv.pdf

Wuenscher R, Unterfrauner H, Peticza R, Zeheneter F. 2015. A comparison of 14 soil phosphorus extraction methods applied to 50 agricultural soils from Central Europe. Plant, Soil and Environment. 61:86-96.

Zechmeister HG, Schmitzberger I, Steurer B, Peterseil J, Wrbka T. 2003. The influence of land-use practices and economics on plant species richness in meadows. Biological Conservation. 114:165-177.

Zuur A, Ieno EN, Walker N, Saveliev AA, Smith GM. 2009. Mixed effects models and extensions in ecology with R. New York, NY, US: Springer. 
44 | Chapter 1

\section{Supporting Information to the paper}

Riesch et al. Soil $\mathrm{pH}$ and phosphorus drive species composition and richness in seminatural heathlands and grasslands unaffected by twentieth-century agricultural intensification. Plant Ecology \& Diversity

Figure S1. Map of the study area.

Appendix S1. Floristic details to the NMDS results.

Figure S2. NMDS ordinations of heathland and grassland plant communities.

Table S1. Extractable soil P-ranges from selected studies.

Table S2. Composition of seed mixtures.

Table S3. Species list including Grime strategy type and Ellenberg indicator values.

Table S4. Plot characteristics in heathlands and grasslands.

Table S5. Linear and non-linear relationships between NMDS scores and plot characteristics.

Table S6. Ranking of candidate models for heathland and grassland species richness. 


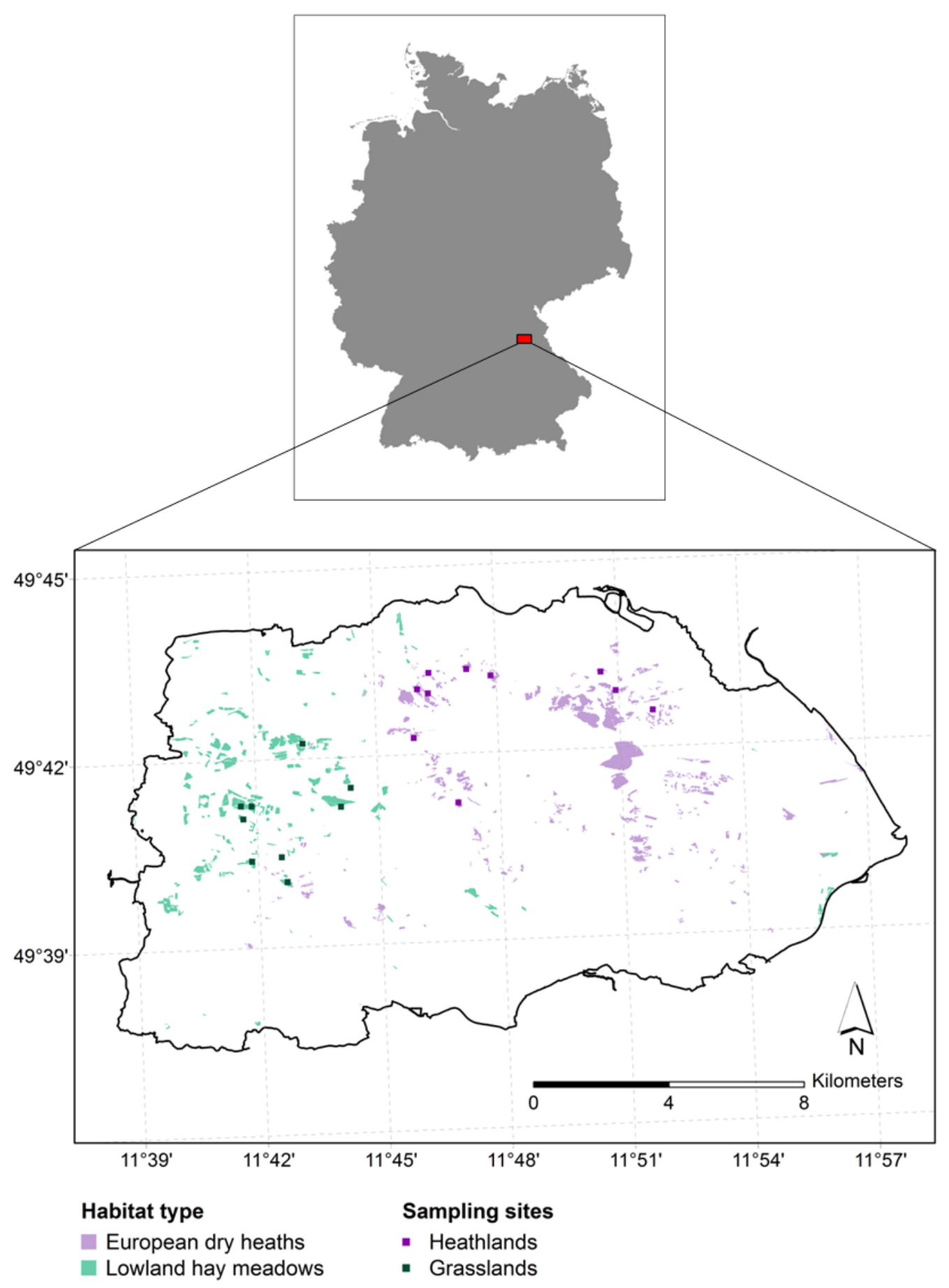

Figure S1: Location of the sampling sites in heathlands (10) and grasslands (nine) at Grafenwöhr military training area (GTA) in Bavaria, Germany. Each site comprised four plots in heathlands and six plots in grasslands, respectively. Shaded areas indicate the occurrence of the Natura 2000 habitat types 4030, European dry heaths, and 6510, lowland hay meadows, according to the draft of the Natura 2000 management plan (2013/2014) for the Site of Community Importance and Special Area of Conservation US-Truppenübungsplatz Grafenwöhr (DE6336301). 

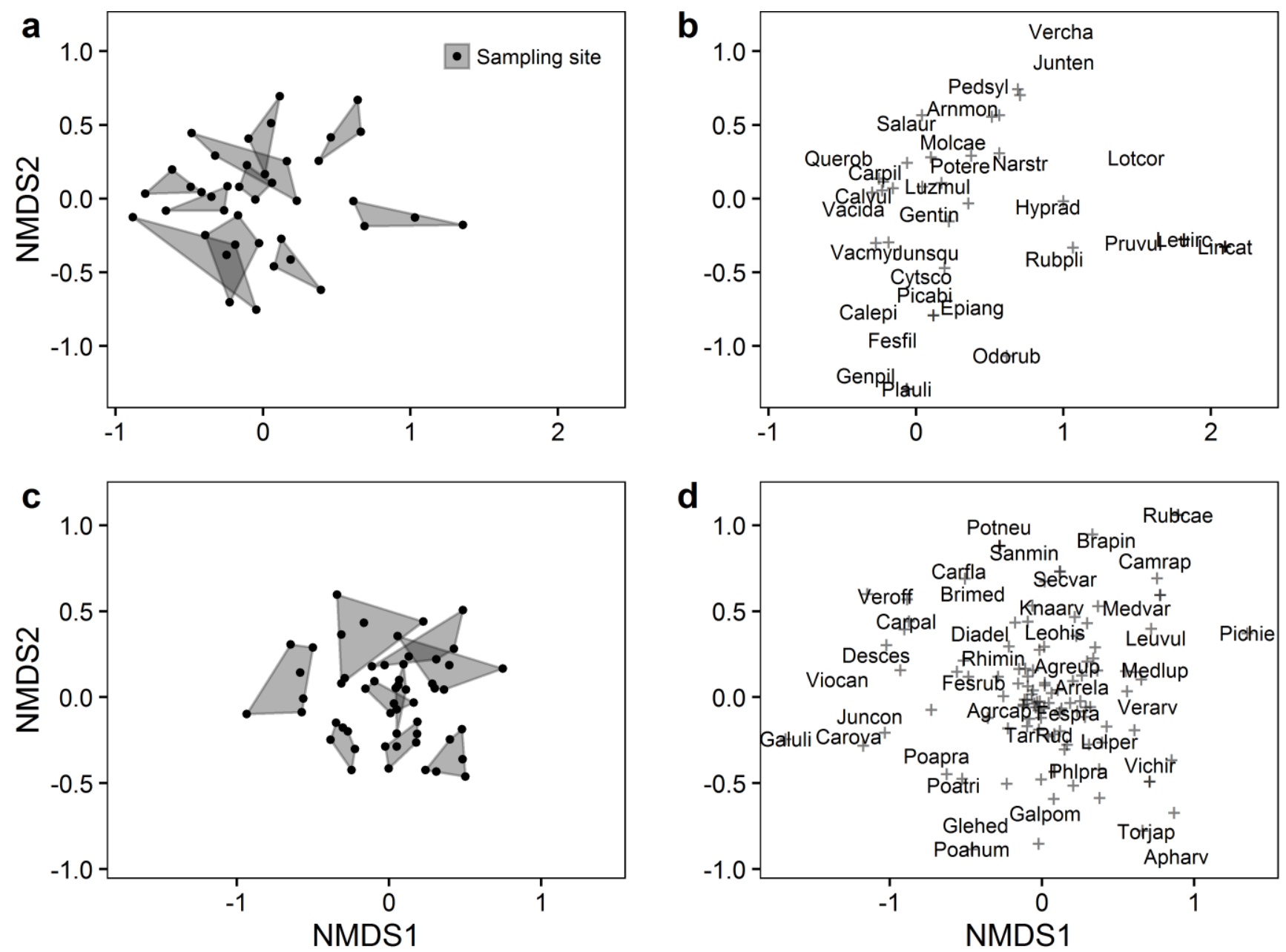

Figure S2: NMDS ordination of vascular plant species composition of (a) 40 plots surveyed in heathlands and (c) 54 plots surveyed in grasslands. Sampling sites are visualised by shaded hulls. The first NMDS axis parallels the soil $\mathrm{pH}$ gradient of plots. Individual species scores for (b) heathlands and (d) grasslands are shown in the same ordination space. The name of the species with the higher abundance was printed (30 species in heathlands, 40 species in grasslands) if species' name tags overlapped; remaining species are represented by '+'. See Table S3 for abbreviations of species names. 


\section{Appendix S1: Floristic details to the NMDS results}

The two-dimensional NMDS analysis of species biomass percentages per plot reached a solution with stress of 0.19 for heathlands (linear fit $R^{2}=0.83$, non-metric fit $R^{2}=0.96$ ) and 0.20 for grasslands (linear fit $R^{2}=0.80$, non-metric fit $R^{2}=0.95$ ). In most cases, sampling sites were well separated from each other representing the spatial nestedness of the data (Figure S2(a) and (c)). The first axis (which was forced to parallel the $\mathrm{pH}$ gradient constituted by heathland or grassland plots, respectively) captured the largest spread of plots in the ordination space. The arrangement of species' optima in both heathlands and grasslands reflects this gradient (Figure S2(b) and (d)).

In accordance with the trends in soil chemical parameters (cf. Figure 1 in the main text) the NMDS ordinations allowed to delineate subunits of heathland and grassland plant communities. In heathlands, typical species of the Vaccinio-Callunetum Büker 1941 association, such as Calluna vulgaris and Vaccinium spp., occupy the left part of the ordination space. Moving towards the centre, there are species associated with the alliance Violion caninae Schwickerath 1944, e.g. Potentilla erecta, Nardus stricta and Arnica montana. Species related to mesotrophic grassland communities, e.g. Leucanthemum ircutianum, gather on the right side of the ordination space. In the ordination of grasslands, species indicating nutrient scarcity scatter from the left to the upper right side of the ordination space. While the left is governed by species indicative of nutrient-poor siliceous grasslands (Polygalo-Nardetum Oberd. 1957), such as Viola canina, more and more representatives of calcicolous grassland communities, e.g. Brachypodium pinnatum, appear on the right side of the ordination space. Species typical of mesotrophic grassland communities occupy the centre of the ordination space and a conspicuous cluster of ruderal plants, e.g. Aphanes arvensis, is located at the bottom. 
Table S1: Information on selected studies and their results reported on the relationship between plant species richness (SR) and extractable soil phosphorus (P). $n$ is the number of vegetation plots examined. For the studies that used a different P extraction method than CAL, the approximate CAL-P range (mg kg-1) was roughly estimated by CAL-P = Olsen-P * 1.45 (Barberis et al. 1995; Wuenscher et al. 2015) and Olsen-P = EDTA-P * 1.55 (Gilbert et al. 2009 ).

$\mathrm{P}$ concentrations referring to soil volume $\left(\mathrm{mg} \mathrm{l}^{-1}\right)$ were converted to the unit $\mathrm{g} \mathrm{kg}^{-1}$ assuming a soil bulk density of $\left.1.4 \mathrm{~g} \mathrm{~cm}^{-3}\right)$. Approximate CAL-P values for critical soil $\mathrm{P}$ concentrations derived from the literature are given in parentheses.

\begin{tabular}{|c|c|c|c|c|c|c|c|c|c|c|c|}
\hline Study & Location & Vegetation units & Fertilisation & $\begin{array}{l}\text { Mana- } \\
\text { gement }\end{array}$ & $\begin{array}{l}\text { Plot } \\
\text { size }\end{array}$ & $n$ & $\begin{array}{l}\mathrm{P} \text { ex- } \\
\text { traction } \\
\text { method }\end{array}$ & $\begin{array}{l}\text { Soil P } \\
\text { range }\end{array}$ & $\begin{array}{l}\text { Approxi- } \\
\text { mate } \\
\text { CAL-P } \\
\text { range } \\
\left(\mathrm{mg} \mathrm{kg}^{-1}\right)\end{array}$ & $\begin{array}{l}\text { Critical soil P } \\
\text { concentrations }\end{array}$ & $\begin{array}{l}\text { Shape of } \\
\text { SR } \sim \mathrm{P} \\
\text { relation- } \\
\text { ship }\end{array}$ \\
\hline $\begin{array}{l}\text { Ceulemans } \\
\text { et al. } 2013\end{array}$ & $\begin{array}{l}\text { North- } \\
\text { western } \\
\text { Europe } \\
\text { (GB, FR, } \\
\text { BE) }\end{array}$ & Violion caninae alliance & none & $\begin{array}{l}\text { extensive } \\
\text { manage- } \\
\text { ment by } \\
\text { cutting } \\
\text { or cut- } \\
\text { ting and } \\
\text { grazing }\end{array}$ & $4 \mathrm{~m}^{2}$ & 132 & Olsen & $\begin{array}{l}0.4-86.1 \\
\mathrm{mg} \mathrm{kg}^{-1}\end{array}$ & $\begin{array}{l}0.6- \\
124.9\end{array}$ & $\begin{array}{l}<20 \text { species per } 4 \mathrm{~m}^{2} \text { for } \\
\text { Olsen-P }>20 \mathrm{mg} \mathrm{kg}^{-1} \\
\left(29 \mathrm{mg} \mathrm{CAL}-\mathrm{P} \mathrm{kg}^{-1}\right)\end{array}$ & $\begin{array}{l}\text { negative } \\
\text { exponen- } \\
\text { tial }\end{array}$ \\
\hline $\begin{array}{l}\text { Ceulemans } \\
\text { et al. } 2014\end{array}$ & $\begin{array}{l}\text { Europe } \\
\text { (IE, IM, } \\
\text { GB, FR, } \\
\text { BE, NL, } \\
\text { DE, NO, } \\
\text { DK, SE) }\end{array}$ & $\begin{array}{l}\text { Nardus grasslands (Habi- } \\
\text { tat type } 6230 \text { ), lowland } \\
\text { hay meadows (Habitat } \\
\text { type } 6510 \text { ), calcareous } \\
\text { grasslands (Habitat types } \\
6210 \text { and } 2130 \text { ) }\end{array}$ & none & $\begin{array}{l}\text { extensive } \\
\text { manage- } \\
\text { ment by } \\
\text { cutting } \\
\text { or cut- } \\
\text { ting and } \\
\text { grazing }\end{array}$ & $4 \mathrm{~m}^{2}$ & 501 & Olsen & $\begin{array}{l}0-305.5 \\
\mathrm{mg} \mathrm{kg}^{-1}\end{array}$ & $0-442.9$ & $\begin{array}{l}\text { SR at a constant low level } \\
\text { where Olsen-P > } \\
104-130 \mathrm{mg} \mathrm{kg}^{-1} \\
(150.8-188.5 \mathrm{mg} \text { CAL-P } \\
\left.\mathrm{kg}^{-1}\right)\end{array}$ & $\begin{array}{l}\text { negative } \\
\text { log-linear }\end{array}$ \\
\hline
\end{tabular}




\begin{tabular}{|c|c|c|c|c|c|c|c|c|c|c|c|}
\hline Study & Location & Vegetation units & Fertilisation & $\begin{array}{l}\text { Mana- } \\
\text { gement }\end{array}$ & $\begin{array}{l}\text { Plot } \\
\text { size }\end{array}$ & $n$ & $\begin{array}{l}\text { P ex- } \\
\text { traction } \\
\text { method }\end{array}$ & $\begin{array}{l}\text { Soil } \mathrm{P} \\
\text { range }\end{array}$ & $\begin{array}{l}\text { Approxi- } \\
\text { mate } \\
\text { CAL-P } \\
\text { range } \\
\left(\mathrm{mg} \mathrm{kg}^{-1}\right)\end{array}$ & $\begin{array}{l}\text { Critical soil P } \\
\text { concentrations }\end{array}$ & $\begin{array}{l}\text { Shape of } \\
\mathrm{SR} \sim \mathrm{P} \\
\text { relation- } \\
\text { ship }\end{array}$ \\
\hline $\begin{array}{l}\text { Critchley et } \\
\text { al. } 2002\end{array}$ & $\begin{array}{l}\text { GB }(14 \\
\text { environ- } \\
\text { mentally } \\
\text { sensitive } \\
\text { areas) }\end{array}$ & $\begin{array}{l}38 \text { plant communities } \\
\text { within seven main vege- } \\
\text { tation types (calcareous, } \\
\text { mesotrophic and acidic } \\
\text { grasslands, mires, heaths, } \\
\text { swamps, underscrub) }\end{array}$ & $\begin{array}{l}\text { in most } \\
\text { cases low or } \\
\text { absent }\end{array}$ & $\begin{array}{l}\text { primarily } \\
\text { grazing }\end{array}$ & $1 \mathrm{~m}^{2}$ & 569 & Olsen & $\begin{array}{l}1.3-82.2 \\
\mathrm{mg} \mathrm{l}^{-1}\end{array}$ & $\begin{array}{l}2.7- \\
166.9\end{array}$ & $\begin{array}{l}\text { highest SR at } 4-15 \mathrm{mg} \\
\text { Olsen-P } \mathrm{l}^{-1}(8.1-30.5 \mathrm{mg} \\
\text { CAL-P kg- }\end{array}$ & $\begin{array}{l}\text { humped- } \\
\text { back }\end{array}$ \\
\hline $\begin{array}{l}\text { Gilbert et } \\
\text { al. } 2009\end{array}$ & $\begin{array}{l}\text { GB }(11 \\
\text { lowland } \\
\text { grassland } \\
\text { sites })\end{array}$ & $\begin{array}{l}\text { neutral lowland grass- } \\
\text { lands } \\
\text { (Triseto-Polygonion, } \\
\text { Alopecurion, Centaureo- } \\
\text { Cynosuretum, Lolio- } \\
\text { Cynosuretum, Lolio- } \\
\text { Plantaginion, Calthion, } \\
\text { Elymo-Rumicion) }\end{array}$ & $\begin{array}{l}\text { no fertiliza- } \\
\text { tion during } \\
\text { previous } \\
\text { decade }\end{array}$ & $\begin{array}{l}\text { different } \\
\text { intensi- } \\
\text { ties of } \\
\text { grazing } \\
\text { or cut- } \\
\text { ting }\end{array}$ & $1 \mathrm{~m}^{2}$ & 176 & Olsen & $\begin{array}{l}0.1-37.5 \\
\mathrm{mg} \mathrm{kg} \mathrm{kg}^{-1}\end{array}$ & $0.2-54.3$ & $\begin{array}{l}\text { declining SR for increas- } \\
\text { ing Olsen-P }>5 \mathrm{mg} \mathrm{kg}^{-1} \\
(7.3 \mathrm{mg} \text { CAL-P kg-1) }\end{array}$ & $\begin{array}{l}\text { humped- } \\
\text { back }\end{array}$ \\
\hline $\begin{array}{l}\text { Hejcman et } \\
\text { al. } 2010\end{array}$ & $\begin{array}{l}\text { DE } \\
\text { (Rengen } \\
\text { Grassland } \\
\text { Experi- } \\
\text { ment) }\end{array}$ & $\begin{array}{l}\text { Nardus grasslands } \\
\text { (Violion caninae, Polygono- } \\
\text { Trisetion, Arrbenatherion) }\end{array}$ & $\begin{array}{l}\text { five treat- } \\
\text { ments (Ca, } \\
\mathrm{CaN} \text {, } \\
\mathrm{CaNP} \text {, } \\
\mathrm{CaNP}-\mathrm{KCl} \\
\text { and } \mathrm{CaNP} \\
\left.\mathrm{K}_{2} \mathrm{SO}_{4}\right)\end{array}$ & 2 cuts $y^{-1}$ & $\begin{array}{l}0.02- \\
5.76 \mathrm{~m}^{2}\end{array}$ & 30 & CAL & $\begin{array}{l}4.8-425.9 \\
\mathrm{mg} \mathrm{kg}^{-1}\end{array}$ & $\begin{array}{l}4.8- \\
425.9\end{array}$ & $\begin{array}{l}\text { no species indicative of } \\
\text { extensive grasslands, } \\
\text { where Olsen- } \\
\mathrm{P}>20 \mathrm{mg} \mathrm{kg}^{-1}\end{array}$ & $\begin{array}{l}\text { negative } \\
\text { linear }\end{array}$ \\
\hline
\end{tabular}




\begin{tabular}{|c|c|c|c|c|c|c|c|c|c|c|c|}
\hline Study & Location & Vegetation units & Fertilisation & $\begin{array}{l}\text { Mana- } \\
\text { gement }\end{array}$ & $\begin{array}{l}\text { Plot } \\
\text { size }\end{array}$ & $n$ & $\begin{array}{l}\text { P ex- } \\
\text { traction } \\
\text { method }\end{array}$ & $\begin{array}{l}\text { Soil P } \\
\text { range }\end{array}$ & $\begin{array}{l}\text { Approxi- } \\
\text { mate } \\
\text { CAL-P } \\
\text { range } \\
\left(\mathrm{mg} \mathrm{kg}^{-1}\right)\end{array}$ & $\begin{array}{l}\text { Critical soil P } \\
\text { concentrations }\end{array}$ & $\begin{array}{l}\text { Shape of } \\
\text { SR } \sim \mathrm{P} \\
\text { relation- } \\
\text { ship }\end{array}$ \\
\hline $\begin{array}{l}\text { Janssens et } \\
\text { al. } 1998\end{array}$ & $\begin{array}{l}\text { Western } \\
\text { and } \\
\text { Central } \\
\text { Europe } \\
\text { (BE, NL, } \\
\text { GB, ES, } \\
\text { LU) }\end{array}$ & $\begin{array}{l}\text { old permanent grasslands } \\
\text { with different soils and } \\
\text { management }\end{array}$ & $\begin{array}{l}\text { not } \\
\text { specified }\end{array}$ & $\begin{array}{l}1-2 \\
\text { cuts } y^{-1} \\
\text { and } \\
\text { autumn } \\
\text { grazing } \\
\text { in some } \\
\text { cases }\end{array}$ & $100 \mathrm{~m}^{2}$ & 281 & $\begin{array}{l}\text { acetate } \\
+ \\
\text { EDTA } \\
\text { extrac- } \\
\text { tion }\end{array}$ & $\begin{array}{l}0.8-346.7 \\
\mathrm{mg} \mathrm{kg}-1\end{array}$ & $\begin{array}{l}1.8- \\
779.2\end{array}$ & $\begin{array}{l}<20 \text { species per } 100 \mathrm{~m}^{2} \\
\text { on soils with EDTA-P } \\
>50 \mathrm{mg} \mathrm{kg}^{-1}(112.4 \mathrm{mg} \\
\text { CAL-P kg-1); } \\
\text { maximum of species at } \\
40 \mathrm{mg} \text { EDTA-P kg-1 } \\
(58 \mathrm{mg} \text { CAL-P kg-1) }\end{array}$ & $\begin{array}{l}\text { humped- } \\
\text { back }\end{array}$ \\
\hline $\begin{array}{l}\text { Marini et al. } \\
2007\end{array}$ & $\begin{array}{l}\text { IT } \\
\text { (Southern } \\
\text { Alps) }\end{array}$ & $\begin{array}{l}\text { lowland moderate and } \\
\text { high intensive meadows } \\
\text { (Pastinaco-Arrbenatheretum, } \\
\text { Ranunculo repentis- } \\
\text { Alopecuretum pratensis), } \\
\text { mountain intensive } \\
\text { meadows (Trisetetum } \\
\text { flavescentis), semi-natural } \\
\text { low productive meadows } \\
\text { (Bromion erecti) }\end{array}$ & $\begin{array}{l}0-350 \mathrm{~kg} \mathrm{~N} \\
\mathrm{ha}^{-1} \mathrm{y}^{-1}\end{array}$ & $\begin{array}{l}1-4 \\
\text { cuts } y^{-1}\end{array}$ & $100 \mathrm{~m}^{2}$ & 56 & Olsen & $\begin{array}{l}5.7-67.6 \\
\mathrm{mg} \mathrm{kg-1}\end{array}$ & $8.2-98.1$ & $\begin{array}{l}\text { conservation and restora- } \\
\text { tion of species-rich hay } \\
\text { meadows requires low- } \\
\text { level soil Olsen- } \\
\text { P }<26.2 \mathrm{mg} \mathrm{kg}^{-1}(38.0 \mathrm{mg} \\
\text { CAL-P kg-1) }\end{array}$ & $\begin{array}{l}\text { negative } \\
\text { log-linear }\end{array}$ \\
\hline
\end{tabular}




\section{References (Table S1)}

Barberis E, Marsan FA, Scalenghe R, Lammers A, Schwertmann U, Edwards AC, Maguire R, Wilson MJ, Delgado A, Torrent J. 1995. European soils overfertilized with phosphorus: Part 1. Basic properties. Fertilizer Research 45:199-207.

Ceulemans T, Merckx R, Hens M, Honnay O. 2013. Plant species loss from European semi-natural grasslands following nutrient enrichment - is it nitrogen or is it phosphorus? Global Ecology and Biogeography 22:73-82.

Ceulemans T, Stevens CJ, Duchateau L, Jacquemyn H, Gowing DJG, Merckx R, Wallace H, van Rooijen N, Goethem T, Bobbink, R, et al. 2014. Soil phosphorus constrains biodiversity across European grasslands. Global Change Biology 20:3814-3822.

Critchley CNR, Chambers BJ, Fowbert JA, Bhogal A, Rose SC, Sanderson RA. 2002. Plant species richness, functional type and soil properties of grasslands and allied vegetation in English Environmentally Sensitive Areas. Grass and Forage Science 57:82-92.

Gilbert J, Gowing D, Wallace H. 2009. Available soil phosphorus in semi-natural grasslands: assessment methods and community tolerances. Biological Conservation 142:1074-1083.

Hejcman M, Češková M, Schellberg J, Pätzold S. 2010. The Rengen Grassland Experiment: Effect of Soil Chemical Properties on Biomass Production, Plant Species Composition and Species Richness. Folia Geobotanica 45:125-142.

Janssens F, Peeters A, Tallowin JRB, Bakker JP, Bekker RM, Fillat F, Oomes MJM. 1998. Relationship between soil chemical factors and grassland diversity. Plant and Soil 202:69-78.

Marini L, Scotton M, Klimek S, Isselstein J, Pecile A. 2007. Effects of local factors on plant species richness and composition of Alpine meadows. Agriculture, Ecosystems \& Environment 119:281-288.

Wuenscher R, Unterfrauner H, Peticza R, Zeheneter F. 2015. A comparison of 14 soil phosphorus extraction methods applied to 50 agricultural soils from Central Europe. Plant, Soil and Environment 61:86-96. 
Table S2: Composition of seed mixtures designed for sands (heathlands) and calcareous loamy sands (grasslands) used for occasional reseeding on Grafenwöhr military training area.

\begin{tabular}{|c|c|c|c|c|}
\hline \multirow[b]{2}{*}{$\begin{array}{l}\text { Functional } \\
\text { group }\end{array}$} & \multicolumn{2}{|c|}{ Heathlands } & \multicolumn{2}{|c|}{ Grasslands } \\
\hline & Species & $\begin{array}{l}\text { Mass } \\
\text { percent }\end{array}$ & Species & $\begin{array}{l}\text { Mass } \\
\text { percent }\end{array}$ \\
\hline \multirow[t]{7}{*}{ Forbs } & Achillea millefolium & $2.5 \%$ & Achillea millefolium & $4 \%$ \\
\hline & Daucus carota & $2 \%$ & Agrimonia eupatoria & $1 \%$ \\
\hline & Hypericum perforatum & $0.5 \%$ & Cichorium intybus & $4 \%$ \\
\hline & Plantago lanceolata & $2 \%$ & Galium verum & $2 \%$ \\
\hline & Plantago major & $1 \%$ & Pimpinella major & $1 \%$ \\
\hline & Taraxacum officinale & $2 \%$ & Plantago lanceolata & $5 \%$ \\
\hline & & & Polygonum aviculare & $3 \%$ \\
\hline \multirow[t]{3}{*}{ Legumes } & Medicago lupulina & $10 \%$ & Lotus corniculatus & $5 \%$ \\
\hline & Trifolium repens & $20 \%$ & Medicago lupulina & $5 \%$ \\
\hline & & & Trifolium repens & $5 \%$ \\
\hline \multirow[t]{5}{*}{ Grasses } & Agrostis capillaris & $5 \%$ & Bromus erectus & $15 \%$ \\
\hline & Agrostis stolonifera & $5 \%$ & Dactylius glomerata & $20 \%$ \\
\hline & Dactylis glomerata & $20 \%$ & Festuca rubra & $20 \%$ \\
\hline & Festuca rubra & $15 \%$ & Phleum pratense & $5 \%$ \\
\hline & Festuca ovina & $15 \%$ & Trisetum flavescens & $5 \%$ \\
\hline
\end{tabular}


Table S3: List of vascular plant species found on 40 and 54 plots of $25 \mathrm{~m}^{2}$ in heathlands and grasslands (abbreviations of species names or symbol ' + ' relate to the representation in Figure S2(b) and (d)) on Grafenwoehr military training area in Bavaria, Germany. Functional strategy refers to Grime (1979): 'C' - competitive strategy, 'S' - stress-tolerant strategy, 'R' ruderal strategy (according to Hunt et al. (2004); [cited 2016 Feb 05]; Available from: http://people.exeter.ac.uk/rh203/csr_signature.html). $E_{F}, E_{R}$, and $E_{N}$ are Ellenberg indicator values for soil moisture, soil reaction and nutrient availability, respectively (Ellenberg \& Leuschner 2010); ' $\mathrm{x}$ ' - indifferent behaviour, ' $\sim$ ' - fluctuating water table, '=' indicator of inundated soils. 'NA' denotes missing information.

\begin{tabular}{|c|c|c|c|c|c|c|}
\hline Species & Heathlands & Grasslands & $\begin{array}{l}\text { Functional } \\
\text { strategy }\end{array}$ & $\mathrm{E}_{\mathrm{F}}$ & $\mathrm{E}_{\mathrm{R}}$ & $E_{N}$ \\
\hline Achillea millefolium & + & + & $\mathrm{CR} / \mathrm{CSR}$ & 4 & $\mathrm{x}$ & 5 \\
\hline Achillea ptarmica & & + & $\mathrm{CR} / \mathrm{CSR}$ & 8 & 4 & 2 \\
\hline Agrimonia eupatoria & & Agreup & CSR & 4 & 8 & 4 \\
\hline Agrostis capillaris & + & Agrcap & CSR & $\mathrm{x}$ & 4 & 4 \\
\hline Alchemilla glaucescens & & + & CSR & 5 & 4 & 3 \\
\hline Alchemilla monticola & & + & CSR & 5 & 6 & 4 \\
\hline Alchemilla sp. & & + & NA & NA & NA & NA \\
\hline Alchemilla subcrenata & & + & CSR & 5 & 5 & 6 \\
\hline Alchemilla vulgaris & & + & S/CSR & 5 & 6 & 6 \\
\hline Alchemilla xanthochlora & & + & CSR & 7 & 7 & ? \\
\hline Allium vineale & & + & S/CSR & 4 & $\mathrm{x}$ & 7 \\
\hline Alopecurus pratensis & & + & $\mathrm{C} / \mathrm{CSR}$ & 6 & 6 & 7 \\
\hline Anthoxanthum odoratum & + & + & $\mathrm{SR} / \mathrm{CSR}$ & $\mathrm{x}$ & 5 & $\mathrm{x}$ \\
\hline Anthriscus sylvestris & & + & CR & 5 & $\mathrm{x}$ & 8 \\
\hline Aphanes arvensis & & Apharv & $\mathrm{R} / \mathrm{SR}$ & 6 & $\mathrm{x}$ & 5 \\
\hline Arenaria serpyllifolia & & + & SR & 4 & 7 & $\mathrm{x}$ \\
\hline Arnica montana & Arnmon & & CSR & 5 & 3 & 2 \\
\hline Arrhenatherum elatius & & Arrela & $\mathrm{C} / \mathrm{CSR}$ & $\mathrm{x}$ & 7 & 7 \\
\hline Bellis perennis & & + & $\mathrm{R} / \mathrm{CSR}$ & 5 & $\mathrm{x}$ & 6 \\
\hline Betonica officinalis & & + & $\mathrm{S}$ & $\mathrm{x} \sim$ & $\mathrm{x}$ & 3 \\
\hline Betula pendula & + & & $\mathrm{C} / \mathrm{SC}$ & $\mathrm{x}$ & $\mathrm{x}$ & $\mathrm{x}$ \\
\hline Brachypodium pinnatum & & Brapin & $\mathrm{SC}$ & 4 & 7 & 4 \\
\hline Briza media & & Brimed & $\mathrm{S}$ & $\mathrm{x}$ & $\mathrm{x}$ & 2 \\
\hline Bromus hordeaceus ssp. bordeaceus & & + & $\mathrm{R} / \mathrm{CR}$ & $x^{\sim}$ & $\mathrm{x}$ & 3 \\
\hline Bromus sterilis & & + & $\mathrm{R} / \mathrm{CR}$ & 4 & $\mathrm{x}$ & 5 \\
\hline Calamagrostis epigejos & Calepi & & $\mathrm{C} / \mathrm{SC}$ & $x^{\sim}$ & $\mathrm{x}$ & 6 \\
\hline Calluna vulgaris & Calvul & & $\mathrm{SC}$ & $\mathrm{x}$ & 1 & 1 \\
\hline Campanula glomerata & & + & $\mathrm{S}$ & 4 & 7 & 3 \\
\hline Campanula patula & & + & CSR & 5 & 7 & 5 \\
\hline Campanula rapunculoides & & Camrap & $\mathrm{CR} / \mathrm{CSR}$ & 4 & 7 & 4 \\
\hline Campanula rotundifolia & + & + & S & $\mathrm{x}$ & $\mathrm{x}$ & 2 \\
\hline Capsella bursa-pastoris & & + & $\mathrm{R}$ & 5 & $\mathrm{x}$ & 6 \\
\hline
\end{tabular}




\begin{tabular}{|c|c|c|c|c|c|c|}
\hline Species & Heathlands & Grasslands & $\begin{array}{l}\text { Functional } \\
\text { strategy }\end{array}$ & $\mathrm{E}_{\mathrm{F}}$ & $E_{R}$ & $\mathrm{E}_{\mathrm{N}}$ \\
\hline Cardamine pratensis & & + & $\mathrm{R} / \mathrm{CSR}$ & 6 & $\mathrm{x}$ & $\mathrm{x}$ \\
\hline Carex flacca & & Carfla & S & $6 \sim$ & 8 & 4 \\
\hline Carex birta & & + & $\mathrm{C} / \mathrm{CSR}$ & $6 \sim$ & $\mathrm{x}$ & 5 \\
\hline Carex leporina & & Carova & S/CSR & $7 \sim$ & 3 & 3 \\
\hline Carexpallescens & & Carpal & S & $6 \sim$ & 4 & 3 \\
\hline Carex pilulifera & Carpil & & S & $5 \sim$ & 3 & 3 \\
\hline Carex spicata & & + & CSR & 4 & 6 & 4 \\
\hline Carlina vulgaris & + & & SR & 4 & 7 & 3 \\
\hline Carum carvi & & + & $\mathrm{C}$ & 5 & $\mathrm{x}$ & 6 \\
\hline Centaurea jacea & & + & $\mathrm{C}$ & $\mathrm{x}$ & $\mathrm{x}$ & $\mathrm{x}$ \\
\hline Centaurea scabiosa & & + & $\mathrm{S} / \mathrm{CSR}$ & 3 & 8 & 4 \\
\hline Centaurium erythraea & & + & $\mathrm{SR}$ & 5 & 6 & 6 \\
\hline Cerastium arvense & & + & $\mathrm{SR} / \mathrm{CSR}$ & 4 & 6 & 4 \\
\hline Cerastium bolosteioides & + & + & $\mathrm{R} / \mathrm{CSR}$ & 5 & $\mathrm{x}$ & 5 \\
\hline Cichorium intybus & & + & CSR & 4 & 8 & 5 \\
\hline Cirsium arvense & & + & $\mathrm{C}$ & $\mathrm{x}$ & $\mathrm{x}$ & 7 \\
\hline Cirsium vulgare & & + & $\mathrm{CR}$ & 5 & 7 & 8 \\
\hline Clinopodium vulgare & & + & $\mathrm{S} / \mathrm{CSR}$ & 4 & 7 & 3 \\
\hline Convolvulus arvensis & & + & $\mathrm{CR}$ & 4 & 7 & $\mathrm{x}$ \\
\hline Crataegus monogyna & & + & SC & 4 & 8 & 4 \\
\hline Crataegus sp. & + & + & NA & NA & NA & $\mathrm{NA}$ \\
\hline Crepis biennis & & + & $\mathrm{R} / \mathrm{CSR}$ & 6 & 6 & 5 \\
\hline Cruciata laevipes & & + & CSR & 6 & 6 & 7 \\
\hline Cynosurus cristatus & & + & CSR & 5 & $\mathrm{x}$ & 4 \\
\hline Cytisus scoparius & Cytsco & & SC & 4 & 3 & 4 \\
\hline Dactylis glomerata & & + & $\mathrm{C} / \mathrm{CSR}$ & 5 & $\mathrm{x}$ & 6 \\
\hline Danthonia decumbens & + & & S & $\mathrm{x}$ & 3 & 2 \\
\hline Daucus carota & & + & $\mathrm{SR} / \mathrm{CSR}$ & 4 & $\mathrm{x}$ & 4 \\
\hline Deschampsia cespitosa ssp. cespitosa & & Desces & $\mathrm{SR} / \mathrm{CSR}$ & $7 \sim$ & $\mathrm{x}$ & 3 \\
\hline Deschampsia flexuosa & + & & $\mathrm{S} / \mathrm{SC}$ & $\mathrm{x}$ & 2 & 3 \\
\hline Dianthus deltoides & & Diadel & $\mathrm{S} / \mathrm{CSR}$ & 3 & 3 & 2 \\
\hline Elymus repens ssp. repens & & + & $\mathrm{C} / \mathrm{CR}$ & $\mathrm{x} \sim$ & $\mathrm{x}$ & 7 \\
\hline Epilobium angustifolium & Epiang & & $\mathrm{C}$ & 5 & 5 & 8 \\
\hline Equisetum arvense & & + & CR & $\mathrm{x} \sim$ & $\mathrm{x}$ & 3 \\
\hline Erigeron acris ssp. acris & + & & SR & 4 & 8 & 2 \\
\hline Euphorbia cyparissias & & + & CSR & 3 & $\mathrm{x}$ & 3 \\
\hline Euphrasia micrantha & + & & $\mathrm{R}$ & 5 & 2 & 1 \\
\hline Festuca filiformis & Fesfil & & SC & 4 & 3 & 2 \\
\hline Festuca ovina & + & & S & $\mathrm{x}$ & 3 & 1 \\
\hline Festuca pratensis & & Fespra & CSR & 6 & $\mathrm{x}$ & 6 \\
\hline
\end{tabular}




\begin{tabular}{|c|c|c|c|c|c|c|}
\hline Species & Heathlands & Grasslands & $\begin{array}{l}\text { Functional } \\
\text { strategy }\end{array}$ & $\mathrm{E}_{\mathrm{F}}$ & $E_{R}$ & $\mathrm{E}_{\mathrm{N}}$ \\
\hline Festuca rubra ssp. rubra & & Fesrub & CSR & 6 & 6 & $\mathrm{x}$ \\
\hline Fragaria vesca & & + & CSR & 5 & $\mathrm{x}$ & 6 \\
\hline Fragaria viridis & & + & CSR & 3 & 8 & 3 \\
\hline Galium album & & + & $\mathrm{C} / \mathrm{CSR}$ & 5 & 7 & 5 \\
\hline Galium pumilum & & + & CSR & $4 \sim$ & 4 & 2 \\
\hline Galium uliginosum & & Galuli & S/CSR & $8 \sim$ & $\mathrm{x}$ & 2 \\
\hline Galium verum & + & + & SC/CSR & $4 \sim$ & 7 & 3 \\
\hline Galium $x$ pommeranicum & & Galpom & NA & NA & NA & NA \\
\hline Genista pilosa & Genpil & & SC & $\mathrm{x}$ & 2 & 1 \\
\hline Genista tinctoria & Gentin & & SC & $6 \sim$ & 6 & 1 \\
\hline Geranium columbinum & & + & SR & 4 & 7 & 7 \\
\hline Geranium dissectum & & + & $\mathrm{R} / \mathrm{SR}$ & 5 & 8 & 5 \\
\hline Geum urbanum & & + & S/CSR & 5 & $\mathrm{x}$ & 7 \\
\hline Glechoma hederacea & & Glehed & CSR & 6 & $\mathrm{x}$ & 7 \\
\hline Helictotrichon pubescens & & + & $\mathrm{S} / \mathrm{CSR}$ & 3 & $\mathrm{x}$ & 4 \\
\hline Heracleum sphondylium & & + & $\mathrm{CR}$ & 5 & $\mathrm{x}$ & 8 \\
\hline Hieracium lachenalii & + & & $\mathrm{S} / \mathrm{CSR}$ & 4 & 4 & 2 \\
\hline Hieracium pilosella & + & & $\mathrm{S} / \mathrm{CSR}$ & 4 & $\mathrm{x}$ & 2 \\
\hline Hieracium sabaudum & + & & $\mathrm{S} / \mathrm{CSR}$ & 4 & 4 & 2 \\
\hline Hieracium sp. & + & & $\mathrm{S} / \mathrm{CSR}$ & NA & NA & NA \\
\hline Hieracium umbellatum & & + & $\mathrm{S} / \mathrm{CSR}$ & 4 & 4 & 2 \\
\hline Holcus lanatus & + & + & CSR & 6 & $\mathrm{x}$ & 5 \\
\hline Hypericum maculatum agg. & & + & $\mathrm{CR} / \mathrm{CSR}$ & $6 \sim$ & 3 & 2 \\
\hline Hypericum perforatum & + & + & $\mathrm{CR} / \mathrm{CSR}$ & 4 & 6 & 4 \\
\hline Hypochaeris radicata & Hyprad & + & CSR & 5 & 4 & 3 \\
\hline Juncus conglomeratus & + & Juncon & $\mathrm{C} / \mathrm{SC}$ & $7 \sim$ & 4 & 3 \\
\hline Juncus squarrosus & Junsqu & & $\mathrm{S} / \mathrm{SC}$ & $7 \sim$ & 1 & 1 \\
\hline Juncus tenuis & Junten & + & CSR & 6 & 5 & 5 \\
\hline Knautia arvensis & & Knaarv & CSR & 4 & $\mathrm{x}$ & 4 \\
\hline Lathyrus pratensis & & + & CSR & 6 & 7 & 6 \\
\hline Leontodon hispidus ssp. hispidus & & Leohis & S/CSR & 5 & 7 & 6 \\
\hline Leontodon saxatile & + & & $\mathrm{SR} / \mathrm{CSR}$ & $6 \sim$ & 6 & 5 \\
\hline Leontodon sp. & + & & NA & NA & NA & NA \\
\hline Leucanthemum ircutianum & Leuirc & + & $\mathrm{C}$ & 4 & $\mathrm{x}$ & 3 \\
\hline Leucanthemum vulgare & & Leuvul & $\mathrm{C} / \mathrm{CSR}$ & 4 & $\mathrm{x}$ & 3 \\
\hline Linum catharticum & Lincat & & SR & $\mathrm{x}$ & 7 & 2 \\
\hline Lolium perenne & & Lolper & $\mathrm{CR} / \mathrm{CSR}$ & 5 & 7 & 7 \\
\hline Lotus corniculatus & Lotcor & + & S/CSR & 4 & 7 & 3 \\
\hline Luzula campestris & + & + & $\mathrm{S} / \mathrm{CSR}$ & 4 & 3 & 3 \\
\hline Luzula multiflora & Luzmul & & S & $5 \sim$ & 5 & 3 \\
\hline
\end{tabular}




\begin{tabular}{|c|c|c|c|c|c|c|}
\hline Species & Heathlands & Grasslands & $\begin{array}{l}\text { Functional } \\
\text { strategy }\end{array}$ & $\mathrm{E}_{\mathrm{F}}$ & $\mathrm{E}_{\mathrm{R}}$ & $\mathrm{E}_{\mathrm{N}}$ \\
\hline Lychnis flos-cuculi & & + & CSR & $7 \sim$ & $\mathrm{x}$ & $\mathrm{x}$ \\
\hline Medicago falcata/varia & & Medvar & $\mathrm{C} / \mathrm{CSR}$ & 3 & 9 & 3 \\
\hline Medicago lupulina & & Medlup & $\mathrm{R} / \mathrm{SR}$ & 4 & 8 & $\mathrm{x}$ \\
\hline Melampyrum pratense & + & & SR & 5 & 3 & 2 \\
\hline Melampyrum sylvaticum & + & & CR & 5 & 2 & 2 \\
\hline Mentha arvensis & & + & $\mathrm{CR}$ & $7 \sim$ & $\mathrm{x}$ & $\mathrm{x}$ \\
\hline Molinia caerulea & Molcae & & SC & 7 & $\mathrm{x}$ & 2 \\
\hline Nardus stricta & Narstr & & S & $\mathrm{x} \sim$ & 2 & 2 \\
\hline Odontites rubra & Odorub & + & $\mathrm{R}$ & $5 \sim$ & 7 & 5 \\
\hline Ononis sp. & & + & NA & NA & NA & NA \\
\hline Pedicularis sylvatica & Pedsyl & & SR & $8 \sim$ & 1 & 2 \\
\hline Phleum pratense & & Phlpra & CSR & 5 & $\mathrm{x}$ & 7 \\
\hline Picea abies & Picabi & & $\mathrm{C}$ & $\mathrm{x}$ & $\mathrm{x}$ & $\mathrm{x}$ \\
\hline Picris hieracioides & & Pichie & $\mathrm{R} / \mathrm{CSR}$ & 4 & 8 & 4 \\
\hline Pimpinella major & & + & CSR & 5 & 7 & 6 \\
\hline Pimpinella saxifraga & & + & $\mathrm{S} / \mathrm{SR}$ & 3 & $\mathrm{x}$ & 2 \\
\hline Pinus sylvestris ssp. sylvestris & + & & $\mathrm{C}$ & $\mathrm{x}$ & $\mathrm{x}$ & $\mathrm{x}$ \\
\hline Plantago lanceolata & & + & CSR & $\mathrm{x}$ & $\mathrm{x}$ & $\mathrm{x}$ \\
\hline Plantago major & & + & $\mathrm{R} / \mathrm{CSR}$ & 5 & $\mathrm{x}$ & 6 \\
\hline Plantago media & & + & S/CSR & 4 & 7 & 3 \\
\hline Plantago uliginosa & Plauli & & $\mathrm{R}$ & $7=$ & 5 & 4 \\
\hline Poa angustifolia & & + & S/CSR & $\mathrm{x}$ & $\mathrm{x}$ & 3 \\
\hline Poa bumilis & & Poahum & $\mathrm{C}$ & 5 & 6 & 3 \\
\hline Poapratensis & & Poapra & CSR & 5 & $\mathrm{x}$ & 6 \\
\hline Poa trivialis & & Poatri & $\mathrm{CR} / \mathrm{CSR}$ & 7 & $\mathrm{x}$ & 7 \\
\hline Polygala serpyllifolia & + & & S & 6 & 2 & 2 \\
\hline Polygala vulgaris & & + & S & 4 & 3 & 2 \\
\hline Populus tremula & + & + & SC & 5 & $\mathrm{x}$ & $\mathrm{x}$ \\
\hline Potentilla anserina & & + & $\mathrm{CR} / \mathrm{CSR}$ & $6 \sim$ & $\mathrm{x}$ & 7 \\
\hline Potentilla argentea & & + & $\mathrm{S} / \mathrm{CSR}$ & 2 & 3 & 1 \\
\hline Potentilla erecta & Potere & & $\mathrm{S} / \mathrm{CSR}$ & $\mathrm{x}$ & $\mathrm{x}$ & 2 \\
\hline Potentilla neumanniana & & Potneu & S & 3 & 7 & 2 \\
\hline Potentilla recta & & + & CSR & 3 & 5 & 2 \\
\hline Potentilla reptans & & + & $\mathrm{CR} / \mathrm{CSR}$ & 6 & 7 & 5 \\
\hline Primula veris & & + & $\mathrm{S} / \mathrm{CSR}$ & 4 & 8 & 3 \\
\hline Prunella vulgaris & Pruvul & + & CSR & 5 & 7 & $\mathrm{x}$ \\
\hline Prunus spinosa & & + & SC & 4 & 7 & $\mathrm{x}$ \\
\hline Pteridium aquilinum & + & & $\mathrm{C}$ & $5 \sim$ & 3 & 3 \\
\hline Pyrus communis & & + & $\mathrm{C}$ & 5 & 8 & $\mathrm{x}$ \\
\hline Quercus robur & Querob & & SC & $\mathrm{x}$ & $\mathrm{x}$ & $\mathrm{x}$ \\
\hline
\end{tabular}




\begin{tabular}{|c|c|c|c|c|c|c|}
\hline Species & Heathlands & Grasslands & $\begin{array}{l}\text { Functional } \\
\text { strategy }\end{array}$ & $E_{F}$ & $\mathrm{E}_{\mathrm{R}}$ & $\mathrm{E}_{\mathrm{N}}$ \\
\hline Ranunculus acris ssp. acris & & + & CSR & 6 & $\mathrm{x}$ & $\mathrm{x}$ \\
\hline Ranunculus bulbosus & & + & SR & 3 & 7 & 3 \\
\hline Ranunculus repens & & + & $\mathrm{CR}$ & $7 \sim$ & $\mathrm{x}$ & 7 \\
\hline Rhinanthus minor & & Rhimin & $\mathrm{R} / \mathrm{SR}$ & 4 & $\mathrm{x}$ & 3 \\
\hline Rubus caesius & & Rubcae & SC & $\mathrm{x}$ & 8 & 7 \\
\hline Rubus plicatus & Rubpli & & $\mathrm{C}$ & 5 & 2 & 3 \\
\hline Rumex acetosa & & + & CSR & $\mathrm{x}$ & $\mathrm{x}$ & 6 \\
\hline Rumex acetosella & + & & $\mathrm{SR} / \mathrm{CSR}$ & 3 & 2 & 2 \\
\hline Rumex crispus & & + & $\mathrm{R} / \mathrm{CR}$ & $\mathrm{x}$ & $\mathrm{x}$ & 6 \\
\hline Salix aurita & Salaur & & $\mathrm{C}$ & $8 \sim$ & 4 & 3 \\
\hline Salix caprea & + & & $\mathrm{C}$ & 6 & 7 & 7 \\
\hline Sanguisorba minor & & Sanmin & $\mathrm{S}$ & 3 & 8 & 2 \\
\hline Saxifraga granulata & & + & $\mathrm{SR} / \mathrm{CSR}$ & 4 & 5 & 3 \\
\hline Scorzoneroides autumnalis & & + & $\mathrm{R} / \mathrm{CSR}$ & 5 & 5 & 5 \\
\hline Securigera varia & & Secvar & $\mathrm{C} / \mathrm{CSR}$ & 4 & 9 & 3 \\
\hline Senecio jacobaea & & + & $\mathrm{R} / \mathrm{CR}$ & $4 \sim$ & 7 & 5 \\
\hline Silaum silaus & & + & $\mathrm{S} / \mathrm{CSR}$ & $\mathrm{x} \sim$ & 7 & 3 \\
\hline Silene vulgaris & & + & CSR & $4 \sim$ & 7 & 4 \\
\hline Silenoideae sp. & & + & NA & NA & NA & NA \\
\hline Stellaria graminea & & + & CSR & 5 & 4 & 3 \\
\hline Taraxacum Sect. Ruderalia & & TarRud & $\mathrm{R} / \mathrm{CSR}$ & 5 & $\mathrm{x}$ & 8 \\
\hline Thymus pulegioides & & + & CSR & 4 & $\mathrm{x}$ & 1 \\
\hline Torilis japonica & & Torjap & $\mathrm{SR} / \mathrm{CSR}$ & 5 & 8 & 8 \\
\hline Tragopogon pratense & & + & $\mathrm{CR} / \mathrm{CSR}$ & 4 & 7 & 6 \\
\hline Trifolium campestre & & + & SR & 4 & 6 & 3 \\
\hline Trifolium dubium & & + & $\mathrm{R} / \mathrm{SR}$ & 4 & 6 & 4 \\
\hline Trifolium medium & + & + & $\mathrm{SC} / \mathrm{CSR}$ & 4 & 6 & 3 \\
\hline Trifolium pratense & & + & CSR & 5 & $\mathrm{x}$ & $\mathrm{x}$ \\
\hline Trifolium repens & & + & $\mathrm{CR} / \mathrm{CSR}$ & 5 & 6 & 6 \\
\hline Trisetum flavescens & & + & CSR & $\mathrm{x}$ & $\mathrm{x}$ & 5 \\
\hline Vaccinium myrtillus & Vacmyr & & SC & $\mathrm{x}$ & 2 & 3 \\
\hline Vaccinium uliginosum & + & & SC & $\mathrm{x}$ & 1 & 3 \\
\hline Vaccinium vitis-idaea & Vacida & & $\mathrm{S} / \mathrm{SC}$ & $4 \sim$ & 2 & 1 \\
\hline Veronica arvensis & & Verarv & SR & $\mathrm{x}$ & 6 & $\mathrm{x}$ \\
\hline Veronica chamaedrys & Vercha & + & CSR & 5 & $\mathrm{x}$ & $\mathrm{x}$ \\
\hline Veronica officinalis & + & Veroff & $\mathrm{S} / \mathrm{CSR}$ & 4 & 3 & 4 \\
\hline Veronica serpyllifolia & & + & $\mathrm{R} / \mathrm{CSR}$ & 5 & 5 & 5 \\
\hline Vicia angustifolia & & + & $\mathrm{R} / \mathrm{CSR}$ & $\mathrm{x}$ & $\mathrm{x}$ & $\mathrm{x}$ \\
\hline Vicia cracca & & + & $\mathrm{C} / \mathrm{CSR}$ & 6 & $\mathrm{x}$ & $\mathrm{x}$ \\
\hline Vicia birsuta & & Vichir & $\mathrm{R} / \mathrm{CSR}$ & 4 & $\mathrm{x}$ & 4 \\
\hline
\end{tabular}




\begin{tabular}{lllllll}
\hline & & \multicolumn{2}{c}{ Functional } \\
Species & Heathlands & Grasslands & strategy & $\mathrm{E}_{\mathrm{F}}$ & $\mathrm{E}_{\mathrm{R}}$ & $\mathrm{E}_{\mathrm{N}}$ \\
\hline Vicia lathyroides & & + & $\mathrm{SR}$ & 2 & 3 & 2 \\
Vicia sepium & & + & $\mathrm{C} / \mathrm{CSR}$ & 5 & 6 & 5 \\
Vicia tetrasperma & & + & $\mathrm{R} / \mathrm{CR}$ & 5 & 5 & 5 \\
Viola canina & + & Viocan & $\mathrm{S}$ & 4 & 3 & 2 \\
Viola birta & + & $\mathrm{S}$ & 3 & 8 & 3 \\
\hline
\end{tabular}

\section{References (Table S3)}

Ellenberg H, Leuschner C. 2010. Vegetation Mitteleuropas mit den Alpen. Stuttgart, DE: UTB Ulmer. Grime JP. 1979. Plant strategies and vegetation processes. Chichester, UK: Wiley.

Hunt R, Hodgson JG, Thompson K, Bungener P, Dunnett NP, Askew AP. 2004. A new practical tool for deriving a functional signature for herbaceous vegetation. Appl Veg Sci. 7:163-170. 
Table S4: Summary statistics of plot characteristics (species richness, plant cover [\%], herbaceous canopy height $[\mathrm{cm}]$, functional group ratio and biomass percentage weighted averages of Ellenberg indicator values and Grime strategy type components).

\begin{tabular}{|c|c|c|c|c|c|c|c|c|}
\hline \multirow[b]{2}{*}{ Parameter } & \multicolumn{4}{|c|}{ Heathlands } & \multicolumn{4}{|c|}{ Grasslands } \\
\hline & Min & Max & Mean & SEM & Min & Max & Mean & SEM \\
\hline SR & 4.00 & 28.00 & 14.10 & 0.81 & 33.00 & 61.00 & 45.89 & 0.83 \\
\hline cover & 35.00 & 90.00 & 60.10 & 2.33 & 60.00 & 96.00 & 83.13 & 1.35 \\
\hline canopy height & 0.00 & 100.00 & 59.50 & 4.85 & 65.00 & 120.00 & 92.69 & 1.76 \\
\hline FG ratio & 0.00 & 0.82 & 0.12 & 0.03 & 1.00 & 9.00 & 3.46 & 0.30 \\
\hline $\mathrm{E}_{\mathrm{F}}$ & 4.00 & 6.81 & 5.33 & 0.15 & 4.33 & 5.84 & 5.21 & 0.05 \\
\hline $\mathrm{E}_{\mathrm{R}}$ & 1.00 & 1.51 & 1.16 & 0.02 & 5.14 & 7.19 & 6.09 & 0.07 \\
\hline$E_{N}$ & 1.00 & 1.66 & 1.22 & 0.03 & 3.81 & 5.90 & 5.02 & 0.06 \\
\hline C strategy & 0.45 & 0.55 & 0.50 & 0.00 & 0.29 & 0.51 & 0.36 & 0.01 \\
\hline S strategy & 0.45 & 0.55 & 0.50 & 0.00 & 0.27 & 0.39 & 0.32 & 0.00 \\
\hline R strategy & 0.00 & 0.03 & 0.00 & 0.00 & 0.23 & 0.43 & 0.32 & 0.01 \\
\hline
\end{tabular}


Table S5: Results of gradient analysis of linear and non-linear relationships between NMDS scores of heathland and grassland communities and plot characteristics including soil chemical parameters. Significance of linear relationships was tested by permutations $(n=10,000)$ and significance of non-linear relationships was tested in generalised additive models.

\begin{tabular}{|c|c|c|c|c|}
\hline \multirow[b]{2}{*}{ Parameter } & \multicolumn{2}{|c|}{ Linear response } & \multicolumn{2}{|c|}{$\begin{array}{l}\text { Non-linear } \\
\text { response }\end{array}$} \\
\hline & $R^{2}$ & $p^{\mathrm{a}}$ & $\mathrm{R}^{2}$ & $p^{\mathrm{a}}$ \\
\hline \multicolumn{5}{|l|}{ Heathlands } \\
\hline $\mathrm{pH}$ & 0.73 & 0.002 & 0.86 & $<0.001$ \\
\hline $\mathrm{P}$ & 0.34 & 0.386 & 0.60 & 0.077 \\
\hline K & 0.15 & 0.764 & 0.61 & 0.392 \\
\hline $\mathrm{Mg}$ & 0.20 & 0.767 & 0.60 & 0.409 \\
\hline SR & 0.90 & $<0.001$ & 0.93 & $<0.001$ \\
\hline cover & 0.08 & 0.991 & 0.74 & 0.269 \\
\hline canopy height & 0.36 & 0.022 & 0.59 & 0.007 \\
\hline FG ratio & 0.57 & 0.020 & 0.89 & $<0.001$ \\
\hline $\mathrm{E}_{\mathrm{F}}$ & 0.65 & 0.080 & 0.66 & 0.001 \\
\hline$E_{R}$ & 0.32 & 0.092 & 0.59 & 0.023 \\
\hline $\mathrm{E}_{\mathrm{N}}$ & 0.27 & 0.179 & 0.53 & 0.016 \\
\hline C strategy & 0.06 & 0.666 & 0.36 & 0.675 \\
\hline S strategy & 0.02 & 0.850 & 0.12 & 0.970 \\
\hline R strategy & 0.32 & 0.279 & 0.55 & $<0.001$ \\
\hline \multicolumn{5}{|l|}{ Grasslands } \\
\hline $\mathrm{pH}$ & 0.53 & 0.001 & 0.52 & $<0.001$ \\
\hline $\mathrm{P}$ & 0.17 & 0.165 & 0.50 & 0.313 \\
\hline K & 0.07 & 0.467 & 0.38 & 0.055 \\
\hline $\mathrm{Mg}$ & 0.16 & 0.004 & 0.79 & 0.013 \\
\hline SR & 0.36 & 0.007 & 0.41 & $<0.001$ \\
\hline cover & 0.45 & 0.050 & 0.63 & 0.002 \\
\hline canopy height & 0.42 & 0.221 & 0.55 & 0.015 \\
\hline FG ratio & 0.04 & 0.439 & 0.51 & $<0.001$ \\
\hline $\mathrm{E}_{\mathrm{F}}$ & 0.40 & $<0.001$ & 0.74 & $<0.001$ \\
\hline $\mathrm{E}_{\mathrm{R}}$ & 0.58 & $<0.001$ & 0.62 & $<0.001$ \\
\hline $\mathrm{E}_{\mathrm{N}}$ & 0.66 & $<0.001$ & 0.74 & $<0.001$ \\
\hline C strategy & 0.38 & 0.054 & 0.52 & $<0.001$ \\
\hline S strategy & 0.43 & 0.003 & 0.60 & 0.001 \\
\hline R strategy & 0.44 & 0.028 & 0.67 & 0.028 \\
\hline
\end{tabular}

aBold font indicates statistical significance $(p<0.05)$ 
Table S6: Overview of candidate linear mixed effects models (cumulative Akaike weight, acc $w_{i}, \leq 0.95$ ) explaining species richness in heathlands and grasslands based on soil chemical parameters listing degrees of freedom ( $d f)$, log-likelihood (logLik), small sample size corrected Akaike information criterion (AICc), its difference to the best ranking model ( $\triangle \mathrm{AICc})$, model weights $\left(w_{i}\right)$, which are standardised to sum to one, as well as marginal $\left(\mathrm{R}_{(m)^{2}}\right)$ and conditional coefficient of determination $\left(R_{(c)}\right)^{2}$. Maximum likelihood estimation was used for AICc-based model comparison, but $\mathrm{R}_{(m)^{2}}$ and $\mathrm{R}_{(c)^{2}}$ were calculated under restricted maximum likelihood estimation.

\begin{tabular}{|c|c|c|c|c|c|c|c|}
\hline Model & $d f$ & $\operatorname{logLik}$ & AICc & $\Delta \mathrm{AICc}$ & $w_{i}$ & $R_{(m)^{2}}^{2}$ & $\mathrm{R}_{(c)^{2}}$ \\
\hline \multicolumn{8}{|l|}{ Heathlands } \\
\hline $\mathrm{pH}$ & 4 & -101.26 & 215.49 & 0.00 & 0.16 & 0.54 & 0.70 \\
\hline $\mathrm{Mg}+\mathrm{pH}$ & 5 & -99.39 & 216.51 & 1.02 & 0.10 & 0.55 & 0.70 \\
\hline $\mathrm{K}^{2}+\mathrm{pH}$ & 5 & -99.16 & 217.15 & 1.66 & 0.07 & 0.55 & 0.68 \\
\hline $\mathrm{K}+\mathrm{pH}$ & 5 & -99.65 & 217.29 & 1.80 & 0.07 & 0.53 & 0.72 \\
\hline $\mathrm{P}^{2}+\mathrm{pH}$ & 5 & -100.04 & 217.66 & 2.18 & 0.05 & 0.55 & 0.70 \\
\hline $\mathrm{Mg}^{2}+\mathrm{pH}$ & 5 & -99.92 & 218.09 & 2.60 & 0.04 & 0.54 & 0.70 \\
\hline $\mathrm{P}+\mathrm{pH}$ & 5 & -100.04 & 218.14 & 2.65 & 0.04 & 0.53 & 0.70 \\
\hline $\mathrm{Mg}+\mathrm{Mg}^{2}+\mathrm{pH}$ & 6 & -97.56 & 218.54 & 3.06 & 0.04 & 0.54 & 0.71 \\
\hline $\mathrm{K}^{2}+\mathrm{Mg}+\mathrm{pH}$ & 6 & -97.40 & 218.57 & 3.08 & 0.03 & 0.55 & 0.69 \\
\hline $\mathrm{Mg}+\mathrm{P}^{2}+\mathrm{pH}$ & 6 & -98.13 & 218.69 & 3.20 & 0.03 & 0.56 & 0.70 \\
\hline $\mathrm{Mg}+\mathrm{P}+\mathrm{pH}$ & 6 & -98.17 & 219.33 & 3.84 & 0.02 & 0.54 & 0.70 \\
\hline $\mathrm{K}+\mathrm{Mg}+\mathrm{pH}$ & 6 & -97.94 & 219.37 & 3.88 & 0.02 & 0.54 & 0.70 \\
\hline $\mathrm{K}^{2}+\mathrm{P}^{2}+\mathrm{pH}$ & 6 & -97.93 & 219.49 & 4.00 & 0.02 & 0.56 & 0.68 \\
\hline $\mathrm{K}+\mathrm{K}^{2}+\mathrm{pH}$ & 6 & -97.71 & 219.52 & 4.03 & 0.02 & 0.53 & 0.70 \\
\hline $\mathrm{K}^{2}+\mathrm{Mg}^{2}+\mathrm{pH}$ & 6 & -97.51 & 219.54 & 4.05 & 0.02 & 0.54 & 0.68 \\
\hline $\mathrm{K}^{2}+\mathrm{Mg}+\mathrm{Mg}^{2}+\mathrm{pH}$ & 7 & -94.91 & 219.54 & 4.05 & 0.02 & 0.55 & 0.69 \\
\hline $\mathrm{K}+\mathrm{Mg}^{2}+\mathrm{pH}$ & 6 & -98.17 & 219.85 & 4.37 & 0.02 & 0.51 & 0.73 \\
\hline $\mathrm{K}+\mathrm{P}^{2}+\mathrm{pH}$ & 6 & -98.53 & 219.86 & 4.37 & 0.02 & 0.53 & 0.71 \\
\hline $\mathrm{K}+\mathrm{P}+\mathrm{pH}$ & 6 & -98.17 & 219.96 & 4.47 & 0.02 & 0.52 & 0.73 \\
\hline $\mathrm{K}^{2}+\mathrm{P}+\mathrm{pH}$ & 6 & -97.93 & 219.96 & 4.48 & 0.02 & 0.54 & 0.68 \\
\hline $\mathrm{P}+\mathrm{P}^{2}+\mathrm{pH}$ & 6 & -98.63 & 220.40 & 4.91 & 0.01 & 0.55 & 0.70 \\
\hline $\mathrm{Mg}^{2}+\mathrm{P}^{2}+\mathrm{pH}$ & 6 & -98.70 & 220.44 & 4.95 & 0.01 & 0.54 & 0.69 \\
\hline $\mathrm{Mg}^{2}+\mathrm{P}+\mathrm{pH}$ & 6 & -98.69 & 220.90 & 5.41 & 0.01 & 0.53 & 0.70 \\
\hline $\mathrm{K}^{2}+\mathrm{Mg}+\mathrm{P}^{2}+\mathrm{pH}$ & 7 & -96.12 & 220.91 & 5.42 & 0.01 & 0.56 & 0.68 \\
\hline $\mathrm{Mg}+\mathrm{Mg}^{2}+\mathrm{P}^{2}+\mathrm{pH}$ & 7 & -96.34 & 221.00 & 5.51 & 0.01 & 0.55 & 0.70 \\
\hline $\mathrm{Mg}+\mathrm{P}+\mathrm{P}^{2}+\mathrm{pH}$ & 7 & -96.61 & 221.37 & 5.88 & 0.01 & 0.56 & 0.70 \\
\hline $\mathrm{Mg}+\mathrm{Mg}^{2}+\mathrm{P}+\mathrm{pH}$ & 7 & -96.32 & 221.51 & 6.03 & 0.01 & 0.53 & 0.71 \\
\hline $\mathrm{K}^{2}+\mathrm{Mg}+\mathrm{P}+\mathrm{pH}$ & 7 & -96.15 & 221.53 & 6.04 & 0.01 & 0.54 & 0.68 \\
\hline $\mathrm{K}+\mathrm{Mg}+\mathrm{P}^{2}+\mathrm{pH}$ & 7 & -96.61 & 221.53 & 6.04 & 0.01 & 0.56 & 0.69 \\
\hline $\mathrm{K}+\mathrm{Mg}+\mathrm{Mg}^{2}+\mathrm{pH}$ & 7 & -96.09 & 221.54 & 6.05 & 0.01 & 0.53 & 0.71 \\
\hline $\mathrm{K}+\mathrm{K}^{2}+\mathrm{Mg}+\mathrm{pH}$ & 7 & -95.95 & 221.56 & 6.08 & 0.01 & 0.54 & 0.68 \\
\hline $\mathrm{K}+\mathrm{K}^{2}+\mathrm{Mg}^{2}+\mathrm{pH}$ & 7 & -95.91 & 221.79 & 6.30 & 0.01 & 0.52 & 0.70 \\
\hline $\mathrm{K}^{2}+\mathrm{Mg}^{2}+\mathrm{P}^{2}+\mathrm{pH}$ & 7 & -96.31 & 222.15 & 6.66 & 0.01 & 0.55 & 0.68 \\
\hline $\mathrm{K}+\mathrm{K}^{2}+\mathrm{P}^{2}+\mathrm{pH}$ & 7 & -96.57 & 222.21 & 6.72 & 0.01 & 0.53 & 0.69 \\
\hline $\mathrm{K}^{2}+\mathrm{P}+\mathrm{P}^{2}+\mathrm{pH}$ & 7 & -96.46 & 222.22 & 6.74 & 0.01 & 0.56 & 0.68 \\
\hline $\mathrm{K}^{2}+\mathrm{Mg}+\mathrm{Mg}^{2}+\mathrm{P}^{2}+\mathrm{pH}$ & 8 & -93.73 & 222.25 & 6.77 & 0.01 & 0.56 & 0.68 \\
\hline $\mathrm{K}+\mathrm{K}^{2}+\mathrm{Mg}+\mathrm{Mg}^{2}+\mathrm{pH}$ & 8 & -93.37 & 222.32 & 6.84 & 0.01 & 0.56 & 0.68 \\
\hline
\end{tabular}




\begin{tabular}{lccccccc}
\hline Model & $d f$ & $\operatorname{logLik}$ & AICc & \multicolumn{1}{c}{$\Delta$ AICc } & $w_{i}$ & $R_{(m)^{2}}$ & $R_{(c)}{ }^{2}$ \\
\hline $\mathrm{K}+\mathrm{K}^{2}+\mathrm{P}+\mathrm{pH}$ & 7 & -96.21 & 222.33 & 6.84 & 0.01 & 0.52 & 0.71 \\
$\mathrm{~K}+\mathrm{P}+\mathrm{P}^{2}+\mathrm{pH}$ & 7 & -96.75 & 222.38 & 6.89 & 0.01 & 0.53 & 0.73 \\
$\mathrm{~K}+\mathrm{Mg}+\mathrm{P}+\mathrm{pH}$ & 7 & -96.50 & 222.44 & 6.95 & 0.00 & 0.52 & 0.71
\end{tabular}

Grasslands

\begin{tabular}{|c|c|c|c|c|c|c|c|}
\hline $\mathrm{K}^{2}+\mathrm{P}+\mathrm{P}^{2}+\mathrm{pH}$ & 7 & -150.87 & 330.86 & 0.00 & 0.14 & 0.44 & 0.48 \\
\hline $\mathrm{K}^{2}+\mathrm{P}+\mathrm{pH}$ & 6 & -154.18 & 331.38 & 0.52 & 0.11 & 0.41 & 0.42 \\
\hline $\mathrm{K}+\mathrm{P}+\mathrm{P}^{2}+\mathrm{pH}$ & 7 & -151.53 & 331.69 & 0.83 & 0.10 & 0.41 & 0.50 \\
\hline $\mathrm{K}+\mathrm{K}^{2}+\mathrm{P}+\mathrm{P}^{2}+\mathrm{pH}$ & 8 & -148.73 & 331.94 & 1.08 & 0.08 & 0.44 & 0.49 \\
\hline $\mathrm{P}+\mathrm{P}^{2}+\mathrm{pH}$ & 6 & -154.45 & 332.43 & 1.58 & 0.07 & 0.39 & 0.46 \\
\hline $\mathrm{K}+\mathrm{K}^{2}+\mathrm{P}+\mathrm{pH}$ & 7 & -152.53 & 333.51 & 2.65 & 0.04 & 0.41 & 0.43 \\
\hline $\mathrm{K}^{2}+\mathrm{Mg}+\mathrm{P}+\mathrm{pH}$ & 7 & -152.49 & 333.55 & 2.69 & 0.04 & 0.41 & 0.43 \\
\hline $\mathrm{K}^{2}+\mathrm{Mg}^{2}+\mathrm{P}+\mathrm{P}^{2}+\mathrm{pH}$ & 8 & -149.57 & 333.64 & 2.78 & 0.04 & 0.43 & 0.48 \\
\hline $\mathrm{K}^{2}+\mathrm{Mg}^{2}+\mathrm{P}+\mathrm{pH}$ & 7 & -152.72 & 333.70 & 2.84 & 0.03 & 0.41 & 0.42 \\
\hline $\mathrm{K}^{2}+\mathrm{Mg}+\mathrm{P}+\mathrm{P}^{2}+\mathrm{pH}$ & 8 & -149.38 & 333.72 & 2.86 & 0.03 & 0.43 & 0.48 \\
\hline $\mathrm{K}+\mathrm{Mg}^{2}+\mathrm{P}+\mathrm{P}^{2}+\mathrm{pH}$ & 8 & -150.07 & 333.98 & 3.12 & 0.03 & 0.42 & 0.50 \\
\hline $\mathrm{K}+\mathrm{P}+\mathrm{P}^{2}$ & 6 & -155.05 & 334.13 & 3.28 & 0.03 & 0.34 & 0.47 \\
\hline $\mathrm{K}+\mathrm{Mg}+\mathrm{P}+\mathrm{P}^{2}+\mathrm{pH}$ & 8 & -149.85 & 334.22 & 3.37 & 0.03 & 0.41 & 0.50 \\
\hline $\mathrm{Mg}^{2}+\mathrm{P}+\mathrm{P}^{2}+\mathrm{pH}$ & 7 & -153.02 & 334.70 & 3.84 & 0.02 & 0.39 & 0.46 \\
\hline $\mathrm{K}+\mathrm{K}^{2}+\mathrm{Mg}^{2}+\mathrm{P}+\mathrm{P}^{2}+\mathrm{pH}$ & 9 & -147.41 & 334.84 & 3.99 & 0.02 & 0.44 & 0.49 \\
\hline $\mathrm{K}+\mathrm{K}^{2}+\mathrm{Mg}+\mathrm{P}+\mathrm{P}^{2}+\mathrm{pH}$ & 9 & -147.20 & 334.96 & 4.10 & 0.02 & 0.43 & 0.50 \\
\hline$K+K^{2}+P+P^{2}$ & 7 & -152.49 & 335.06 & 4.20 & 0.02 & 0.36 & 0.46 \\
\hline $\mathrm{Mg}+\mathrm{P}+\mathrm{P}^{2}+\mathrm{pH}$ & 7 & -152.88 & 335.06 & 4.20 & 0.02 & 0.38 & 0.47 \\
\hline $\mathrm{K}+\mathrm{K}^{2}+\mathrm{Mg}+\mathrm{P}+\mathrm{pH}$ & 8 & -150.86 & 335.84 & 4.99 & 0.01 & 0.40 & 0.43 \\
\hline $\mathrm{P}+\mathrm{pH}$ & 5 & -158.97 & 335.85 & 5.00 & 0.01 & 0.31 & 0.37 \\
\hline $\mathrm{K}+\mathrm{K}^{2}+\mathrm{Mg}^{2}+\mathrm{P}+\mathrm{pH}$ & 8 & -151.07 & 335.92 & 5.06 & 0.01 & 0.40 & 0.43 \\
\hline $\mathrm{K}^{2}+\mathrm{P}+\mathrm{P}^{2}$ & 6 & -155.62 & 336.19 & 5.33 & 0.01 & 0.34 & 0.43 \\
\hline $\mathrm{K}+\mathrm{P}+\mathrm{pH}$ & 6 & -156.50 & 336.30 & 5.44 & 0.01 & 0.32 & 0.42 \\
\hline $\mathrm{K}^{2}+\mathrm{Mg}+\mathrm{Mg}^{2}+\mathrm{P}+\mathrm{pH}$ & 8 & -150.84 & 336.38 & 5.53 & 0.01 & 0.40 & 0.43 \\
\hline $\mathrm{K}^{2}+\mathrm{Mg}+\mathrm{Mg}^{2}+\mathrm{P}+\mathrm{P}^{2}+\mathrm{pH}$ & 9 & -147.73 & 336.67 & 5.81 & 0.01 & 0.43 & 0.48 \\
\hline $\mathrm{K}+\mathrm{Mg}^{2}+\mathrm{P}+\mathrm{P}^{2}$ & 7 & -153.80 & 336.77 & 5.91 & 0.01 & 0.33 & 0.47 \\
\hline $\mathrm{K}+\mathrm{Mg}+\mathrm{P}+\mathrm{P}^{2}$ & 7 & -153.51 & 336.83 & 5.97 & 0.01 & 0.33 & 0.47 \\
\hline $\mathrm{K}+\mathrm{Mg}+\mathrm{Mg}^{2}+\mathrm{P}+\mathrm{P}^{2}+\mathrm{pH}$ & 9 & -148.15 & 337.00 & 6.14 & 0.01 & 0.41 & 0.50 \\
\hline $\mathrm{K}^{2}+\mathrm{Mg}+\mathrm{P}$ & 6 & -156.48 & 337.40 & 6.54 & 0.01 & 0.33 & 0.41 \\
\hline $\mathrm{Mg}+\mathrm{Mg}^{2}+\mathrm{P}+\mathrm{P}^{2}+\mathrm{pH}$ & 8 & -151.11 & 337.58 & 6.72 & 0.01 & 0.39 & 0.47 \\
\hline$K+K^{2}+M g+P+P^{2}$ & 8 & -150.83 & 337.59 & 6.73 & 0.00 & 0.37 & 0.47 \\
\hline $\mathrm{K}+\mathrm{K}^{2}+\mathrm{Mg}^{2}+\mathrm{P}+\mathrm{P}^{2}$ & 8 & -151.09 & 337.63 & 6.77 & 0.00 & 0.36 & 0.46 \\
\hline $\mathrm{P}+\mathrm{P}^{2}$ & 5 & -159.25 & 337.68 & 6.82 & 0.00 & 0.28 & 0.41 \\
\hline $\mathrm{K}^{2}+\mathrm{P}$ & 5 & -159.26 & 337.73 & 6.88 & 0.00 & 0.27 & 0.37 \\
\hline $\mathrm{K}^{2}+\mathrm{Mg}+\mathrm{P}+\mathrm{P}^{2}$ & 7 & -153.61 & 337.77 & 6.91 & 0.00 & 0.35 & 0.45 \\
\hline $\mathrm{K}+\mathrm{K}^{2}+\mathrm{P}$ & 6 & -156.70 & 337.91 & 7.05 & 0.00 & 0.29 & 0.41 \\
\hline $\mathrm{K}+\mathrm{K}^{2}+\mathrm{Mg}+\mathrm{Mg}^{2}+\mathrm{P}+\mathrm{P}^{2}+\mathrm{pH}$ & 10 & -145.55 & 338.04 & 7.19 & 0.00 & 0.43 & 0.49 \\
\hline $\mathrm{K}^{2}+\mathrm{P}+\mathrm{P}^{2}+\mathrm{pH}$ & 7 & -150.87 & 330.86 & 0.00 & 0.14 & 0.44 & 0.48 \\
\hline
\end{tabular}




\section{Chapter 2}

\section{Grazing by wild red deer: Management options for the conservation of semi-natural open habitats}

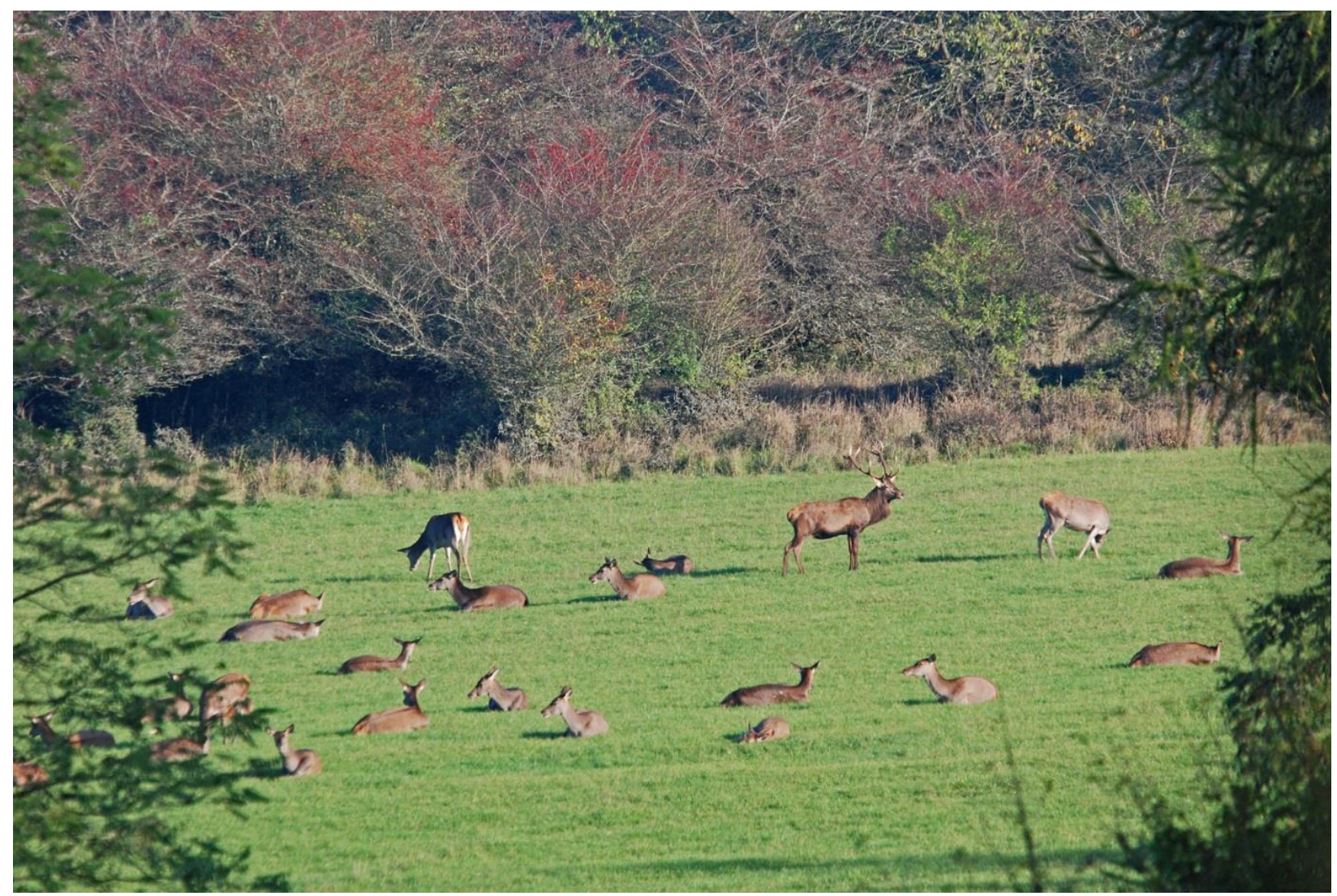

Picture: Marcus Meißner

This chapter is the accepted version of the following article:

Riesch F, Tonn B, Meißner M, Balkenhol N, Isselstein J. 2019. Grazing by wild red deer: Management options for the conservation of semi-natural open habitats. Journal of Applied Ecology 56:1311- 1321, which has been published in final form at https://doi.org/10.1111/1365-2664.13396.

This article may be used for non-commercial purposes in accordance with the Wiley SelfArchiving Policy [http://www.wileyauthors.com/self-archiving]. 


\section{Abstract}

1. Maintaining semi-natural open habitats requires biomass removal, which can be achieved by extensive grazing with livestock species. However, implementing this established conservation management strategy in large or access-restricted areas is often not possible.

2. We investigated grazing by wild and free-ranging red deer (Cervus elaphus) as an alternative conservation management approach on an active military training area in Germany. In grasslands and heathlands protected under the EU Habitats Directive, we quantified aboveground net primary productivity, forage quality and forage removal by red deer over three successive years. To assess synergistic effects between wildlife grazing and additional grassland management measures removing vegetation biomass (i.e. burning, mowing), we conducted our grazing experiment in burnt, mown and untreated grasslands.

3. Annual forage removal by red deer amounted to $35 \%, 44 \%, 48 \%$ and $59 \%$ of the aboveground net primary productivity in burnt, mown and untreated grasslands and untreated heathlands, respectively. Theoretically, a similar annual biomass removal could be obtained by livestock grazing with 0.54 animal units $\mathrm{ha}^{-1}$ in grasslands and 0.45 animal units ha ${ }^{-1}$ in heathlands. In grasslands, daily rates of forage removal peaked in spring and early summer, whereas in heathlands, forage removal rates were only significant in winter.

4. Forage removal rates in grasslands increased with productivity and forage quality, which were both enhanced in mown grasslands. This suggests mowing can increase grassland attractiveness to red deer. Forage removal rates in heathlands did not relate to productivity or forage quality but to standing biomass.

5. Synthesis and applications. We demonstrate that the quantity of forage removed by wild red deer can be comparable to that of livestock in common conservation grazing systems. The seasonal patterns of forage removal by red deer in grasslands and heathlands coincided with the different grazing requirements of these habitats. Especially in large areas of conservation interest, we therefore encourage attempts to modify current wildlife management strategies to allow red deer to forage in open landscapes, which can contribute to the conservation of semi-natural open habitats and also help to reduce damage in forest stands.

\section{Keywords}

Cervus elaphus, European dry heaths, forage, grazing, lowland hay meadows, Natura 2000, rewilding, semi-natural habitat 


\section{Second abstract (German)}

1. Der Erhalt von naturnahen Offenlandschaften erfordert Biomasseentnahme, welche durch eine extensive Beweidung mit Nutztieren erzielt werden kann. In großen oder unzugänglichen Gebieten ist es allerdings häufig nicht möglich, diese etablierte Naturschutzmanagementstrategie umzusetzen.

2. Als ein alternativer Ansatz zum Offenlandmanagement wurde die Beweidung durch wildlebende Rothirsche (Cervus elaphus) auf einem aktiv genutzten Truppenübungsplatz in Deutschland untersucht. In zwei nach FFH-Richtlinie geschützten Lebensraumtypen (Grünland und Heide) wurden oberirdische Primärproduktion, Futterqualität und Biomasseentnahme durch Rothirsche während drei aufeinanderfolgender Jahre erfasst. Um Synergieeffekte zwischen Wildtierbeweidung und zusätzlichen Grünlandpflegemaßnahmen (Brennen, Mähen) zu beurteilen, wurde das Beweidungsexperiment im Grünland auf gebrannten, gemähten sowie ungepflegten Behandlungsflächen durchgeführt.

3. Die jährliche Biomasseentnahme durch Rothirsche belief sich auf durchschnittlich $35 \%, 44 \%$ und $48 \%$ des jährlichen Vegetationsaufwuchses in gebranntem, gemähtem und ungepflegtem Grünland und auf $59 \%$ des jährlichen Vegetationsaufwuchses in ungepflegten Heiden. Dies würde im Durchschnitt einer theoretischen Besatzstärke von 0.54 und 0.45 Großvieheinheiten pro Hektar in Grünland und Heiden entsprechen. Die täglichen Biomasseentnahmeraten waren im Grünland in Frühling und Frühsommer am höchsten, wohingegen in Heiden die höchsten Biomasseentnahmeraten im Winter verzeichnet wurden.

4. Im Grünland nahmen die Biomasseentnahmeraten mit steigender Produktivität und Futterqualität zu. In gemähtem Grünland waren Produktivität und Futterqualität erhöht, sodass sich die Mahd als ein Instrument eignen könnte, um die Attraktivität von Grünland für Rothirsche zu fördern. Die Biomasseentnahmeraten in Heiden hingen nicht mit Produktivität oder Futterqualität, sondern mit der stehenden Biomasse zusammen.

5. Synthese und Anwendungen. Unsere Untersuchungen zeigen, dass die Biomasseentnahme durch wildlebende Rothirsche in einer vergleichbaren Größenordnung wie bei extensiver Nutztierbeweidung liegen kann. Die saisonalen Muster der Biomasseentnahme durch Rothirsche in Grünland und Heiden deckten sich mit den unterschiedlichen Beweidungsansprüchen dieser Lebensraumtypen. Unsere Ergebnisse setzen daher einen Impuls, insbesondere in großen Naturschutzflächen das Wildtiermanagement so anzupassen, dass die Nutzung von Offenlandlebensräumen durch Rothirsche gefördert wird. Auf diese Weise kann ein Beitrag zum Erhalt naturnaher Offenlandlebensräume geleistet und gleichzeitig das Risiko von Schäden in forstlich genutzten Wäldern reduziert werden. 


\section{Introduction}

Biomass removal by grazing, mowing or fire is key to maintaining semi-natural open habitats in temperate regions (MacDougall and Turkington 2007; Tälle et al. 2016; Valkó et al. 2018).

Both agricultural intensification and abandonment, however, have resulted in a continuing loss of semi-natural open habitats and their characteristic species (Poschlod and WallisDeVries 2002; Hooftman and Bullock 2012; Wesche et al. 2012). To compensate for the decline of traditional extensive land use systems, such as pastoral farming (Poschlod et al. 2009; Leuschner and Ellenberg 2017), extensive livestock grazing has become a valuable tool for conservation management in Europe (Van Wieren 1995; Rosenthal et al. 2012; García et al. 2013). The primary mechanism by which biomass removal in general, and grazing in particular, benefits plant diversity in grassland ecosystems is that it enhances the light availability at ground level and thereby alleviates light competition (Borer et al., 2014). Independently from grazer species, nutrient supply, or site productivity, grazing is thus expected to counteract biodiversity losses resulting from anthropogenic nutrient inputs to natural systems (Borer et al. 2014). To develop appropriate conservation strategies for different habitat types, it is, however, essential to account for the effect of habitat productivity on the grazing impact of large herbivores (Bakker et al. 2006). Therefore, target stocking rates for conservation grazing, e.g. laid down by EU agrienvironment schemes (FAS 2017) differ between habitat types to prevent over- as well as undergrazing.

Livestock grazing usually requires fencing or herding and frequent inspection of the animals to ensure health and welfare. Fulfilling these requirements can be difficult and costly where the target area is large or access is restricted. This is especially true for military training areas (MTAs), which bring along even more challenges for conservation management, such as military activities and unexploded ordnance. MTAs are increasingly in the focus of nature conservation because they present a contrast to the intensively used agricultural matrix and, hence, often harbour high biodiversity including large numbers of threatened and endangered species (Warren et al. 2007; Riesch et al. 2018). Active and abandoned MTAs cover considerable areas, for instance more than one million hectares in Central and Eastern Europe (assessed in eight EU countries; Naturstiftung David 2016). In MTAs and other areas where it is difficult to apply established conservation strategies for maintaining open habitats, grazing by wild herbivores might be an alternative management option requiring neither fencing nor regular human presence in the target area. A conservation approach using wild herbivores is furthermore appealing because it is in line with the historical importance of large herbivores for landscape structure and vegetation openness in Pleistocene times (Vera 2000; Bakker et al. 2016) and complies with the increasingly popular concept of rewilding to restore natural ecosystem functions and biodiversity, especially in areas threatened by abandonment (Navarro and Pereira 2012; Svenning et al. 2016). The most widespread extant large autochthonous grazer species in Central Europe, red deer (Cervus elaphus), is therefore of particular interest to conservation management. 
First attempts to deliberately use red deer in conservation management have been made under island (Moore et al. 2015) or fenced conditions (Tschöpe et al. 2011; Fløjgaard et al. 2017) but the interplay between free-ranging red deer and vegetation dynamics in open habitats has not been studied in Central Europe in the context of nature conservation thus far. Regarding the challenge that the conservation of different plant communities requires different grazing intensities (Moore et al. 2015) it is fundamental to quantify the forage removal by free-ranging red deer in habitats differing in productivity and forage quality. As red deer grazing patterns have usually been studied over short periods or within single years, it is furthermore pivotal to assess how seasonal changes in forage productivity and quality drive patterns in forage removal by red deer. In large and heterogeneous areas, the relationship between wild herbivore density and the distribution of their foraging impact is known to be weak (Gordon et al. 2004), so that the applied conservation management would benefit greatly from means to spatially direct grazing activities by free-ranging red deer. Mowing and burning do not only remove biomass but also lead to enhanced forage quantity and quality in the regrowing vegetation, which can attract herbivores (Langvatn and Hanley 1993; Wilmshurst et al. 1995; Rivrud et al. 2016). Consequently, interaction and synergistic effects between large herbivore grazing and mowing (Taylor et al. 2004; Cromsigt and Olff 2008) or burning (Fuhlendorf et al. 2009) are well-known. But it has not yet been tested if the attractiveness of certain areas to red deer and the local forage removal could be increased by additional burning or mowing. An improved understanding of such synergistic effects could provide the basis for influencing the grazing impacts of freeranging red deer within a wider spatial context. For instance, this would be useful for harmonising red deer habitat use with the different grazing requirements of habitat types (Moore et al. 2015).

Our study aims to provide a sound initial assessment if grazing by wild and freeranging red deer in semi-natural open habitats can be quantitatively sufficient for conservation purposes. Therefore, we selected two divergent habitats of high conservation interest, lowland hay meadows and European dry heaths, on an active MTA in Central Europe and sampled data on aboveground net primary productivity and red deer forage removal over three successive years. We hypothesised: (1) forage removal by red deer in open habitats is comparable in magnitude to the amount of forage removed by livestock under recommended conservation grazing schemes (2) seasonal changes in productivity and forage quality are reflected by seasonal patterns in red deer forage removal, (3) additional management (burning, mowing) in grasslands improves forage quality and thus affects red deer forage removal. Our results contribute to developing red deer management strategies promoting grazing in open habitats. Such approaches could prove especially useful for large areas where access restrictions or high costs render conventional conservation methods unfeasible. 


\section{Materials and methods}

\section{Study area}

We investigated red deer grazing on the US Army Garrison Grafenwöhr military training area (GTA) in Bavaria, Germany (49 40' 56" N, $11^{\circ} 47^{\prime} 20^{\prime \prime} \mathrm{E}$ ). The size of GTA is approximately $230 \mathrm{~km}^{2}$, composed of approximately $60 \%$ forest and $40 \%$ different open habitat types. The German Federal Forests Division (Bundesforst) is responsible for the land and wildlife management in forested as well as open areas. Long-time annual average temperature is $8.3 \pm 0.04{ }^{\circ} \mathrm{C}$ and precipitation is $701 \pm$ $4 \mathrm{~mm}$ (1981-2010, mean \pm SE of four weather stations of the German Weather Service (Deutscher Wetterdienst, DWD) in the immediate vicinity; Fig. S1 in Supporting Information). The area has served military purposes for more than a century. Approximately $85 \%$ of GTA belong to the European Natura 2000 conservation network. Wildlife, foremost red deer, is abundant (average annual harvest numbers during the three study years: 1493 red deer, 584 roe deer (Capreolus capreolus), 553 wild boars (Sus scrofa)). Since the 1980s, red deer management by Bundesforst has aimed at reducing damage to the forest by encouraging red deer habitat use of open landscapes. Consequently, hunting in open habitats is mainly limited to driven hunts on few days in early winter in order to minimise disturbing the red deer's natural daily activity patterns (Meißner et al. 2013). By contrast, in the forested areas in the periphery of GTA, which are supposed to fulfil multiple purposes, such as timber production and protection against noise and dust, hunting (driven hunts and stand hunting) is intense during the entire hunting season set by the federal state (01 August-31 January, yearlings: 01 June-31 January). An extensive telemetry study has confirmed that red deer in GTA frequently forage in open habitats and large groups of red deer can be observed in open areas even by daylight (Meißner et al. 2013). Livestock grazing, in contrast, is impossible in most parts of GTA because of intensive military land use and public access restrictions.

\section{Study design}

We established a grazing experiment in two different habitats, lowland hay meadows (EU Habitats Directive Annex I habitat type 6510, hereafter 'grasslands') and European dry heaths (habitat type 4030, 'heathlands'). The grassland habitat type is part of a large, (semi-)open landscape in the western third of the GTA and covers in total c. 340 ha on calcareous soils. The heathland habitat type is dominated by Calluna vulgaris and occurs with a total area of 463 ha in the eastern part of GTA on Triassic sandstone and highly acidic, sandy soils. Soil fertility is generally low in both habitat types (Riesch et al. 2018).

We established five sampling sites (each c. 1 ha in grasslands and c. 0.5 ha in heathlands) per habitat type (Fig. S2). Sampling sites were smaller in heathlands because the accessible heathlands in GTA (outside of the main ordnance impact areas and shooting ranges) occur as small patches within shrub- and forestdominated areas.

In grasslands, which had been mown once per year before the start of the experiment, each sampling site was divided equally into three areas receiving different 
treatments starting in 2015: burnt (B), mown (M) and untreated (U) grassland. Prescribed burning was conducted by Bundesforst at the end of March or at the beginning of April each year. Burning removed an estimated average amount of $80 \%$ of the standing biomass. In the first two study years, however, burning succeeded only on three of the five sites owing to low residual standing biomass at the end of the winter. The $\mathrm{M}$ treatment received one annual cut in July using conventional agricultural machinery. There was one sampling plot per treatment totalling 15 plots in grasslands. In heathlands, we assessed only the U treatment on a total of eight plots (two sites with one plot, three sites with two plots). In both grasslands and heathlands, sampling plot size was $225 \mathrm{~m}^{2}(15 \times 15 \mathrm{~m})$.

The distance between sampling plots and the closest opportunity for red deer to seek cover in shrub or forest ranged from 26 to $164 \mathrm{~m}(69 \pm 5 \mathrm{~m}$, mean $\pm \mathrm{SE})$ in grasslands and 0 to $55 \mathrm{~m}(18 \pm 3 \mathrm{~m})$ in heathlands. The main land cover surrounding grassland plots was unmanaged or managed grassland. In contrast, forests dominated the landscape surrounding heathland plots and the share of managed grassland was negligible (Table S1, C. Raab, unpublished). We assume that different red deer individuals grazed on the experimental plots in grasslands and heathlands as the distance between the sampling sites of the two habitat types is large (Fig. S2) compared to the size of the mean minimum convex polygon home range of red deer in GTA (488 ha, $s d=122$ ha; 34 annual home ranges of 24 female red deer in 20152018; L. Richter, unpublished).

\section{Data collection}

To assess the standing biomass in both habitat types, we used a double-sampling technique (Correll et al. 2003) relying on rising-plate meter measurements of the compressed sward height and calibration cuts (for details see Appendix S1). For each plot, we measured the standing biomass at five annual sampling dates (April, May, June, August and October) in three years (2015-2017). To assess aboveground net primary productivity (ANPP) between succeeding sampling dates, we used movable exclusion cages (Fig. S4, Appendix S1), which allow measuring the actual productivity of previously grazed vegetation (McNaughton et al. 1996). We installed one $1-\mathrm{m}^{2}$-exclusion cage per plot in April 2015. We then moved the cage to a new, randomly chosen position at each sampling date until April 2018, resulting in five growth periods per study year. Red deer forage removal was calculated as the difference in biomass increments of the vegetation temporarily protected from grazing (under the exclusion cage) and the continuously grazed vegetation (on the open plot). To account for the length of growth periods between sampling dates, we present daily rates of productivity and red deer forage removal averaged over sampling sites in each habitat. To calculate the annual ANPP, we summed up the positive biomass increments determined by the exclusion cages over the five growth periods per year (McNaughton et al. 1996). We analogously computed the accumulated annual red deer forage removal.

As the B treatment plots in grasslands were burnt before the first sampling date each year, our data do not accurately represent the productivity and forage removal in the $\mathrm{B}$ treatment during the winter period from October to April. To allow mowing of 
the complete $\mathrm{M}$ treatment plot by conventional large agricultural machinery, the exclusion cages were removed after the June sampling date and reinstalled after mowing. Our data for productivity, yield and forage removal in the $\mathrm{M}$ treatment are hence conservative because we did not account for vegetation growth and forage removal during the time lag (14 days on average) between cage removal and mowing in July.

As we frequently found red deer dung on our plots but very rarely faeces of other species, e.g. hares (Lepus europaeus) or wild boars, we attributed the whole forage removal to red deer. We cannot assess the potential influence of invertebrate herbivores, but we suppose that such small animals were not deterred from our exclusion cages ( $45 \mathrm{~mm}$ mesh size) and foraged equally inside and outside of the cages.

To analyse forage quality as a potential driver of red deer foraging activity, on each sampling date, we collected hand-pluck samples imitating red deer foraging behaviour. We determined crude protein concentration $(\mathrm{CP})$ in plant material (Dumas combustion), as well as organic acid and neutral detergent fibre (oADF, oNDF) by near-infrared spectroscopy for grasslands and by wet-chemical analysis for heathlands (for details see Appendix S2).

\section{Statistical analyses}

We performed all analyses in R (v 3.4.4; R Core Team 2015). We used linear mixed effects (LME) models provided by the package nlme (Pinheiro et al. 2015) to analyse the main and interaction effects of year $(2015,2016,2017)$ and treatment $(B, M, U)$ on the ANPP and accumulated annual red deer forage removal in grasslands. In heathlands, where $U$ was the only treatment, we only analysed the main effect of year.

For each habitat, we also tested the main and interaction effects of year, month (April, May, June, August, October) and treatment on the daily rates of productivity and forage removal as well as on CP, oNDF and oADF. In heathlands, the treatment factor with the single level (U) was omitted.

We used treatment nested in sampling site as a random factor in all grassland models and plot nested in sampling site as a random factor in all heathland models. Variance structure functions were used if necessary to meet assumptions of homoscedasticity and normality of residuals. We report results for the most parsimonious models in terms of second-order Akaike information criterion (AICc).

To further investigate potential factors influencing daily red deer forage removal rates, we ran additional models including either daily productivity $\left(\mathrm{g} \mathrm{m}^{-2} \mathrm{~d}^{-1}\right)$ during the growth period, the distance $(\mathrm{m})$ to cover (shrub or forest), standing biomass at the beginning of the growth period $\left(\mathrm{g} \mathrm{m}^{-2}\right), \mathrm{CP}(\%)$ or oADF $(\%)$ as continuous environmental predictor variables in addition to the experimental predictor variables. We present the results of these models only if the respective environmental variable was retained as a significant effect in the most parsimonious model. 


\section{Results}

The annual forage removal by red deer amounted to 35\% (B), 44\% (M) and 48\% (U) of the ANPP in grasslands and 59\% in heathlands (U), respectively.

Averaged over the three study years, ANPP in grasslands was $20 \%$ higher in the M than in the $\mathrm{B}$ or $\mathrm{U}$ treatment, whereas red deer forage removal did not differ significantly between treatments, but was 12\% higher in 2017 than in 2016 (Tables 1, S3).

Mowing in grasslands yielded $204 \mathrm{~g} \mathrm{~m}^{-2}$ on average. In the M treatment, forage removal of red deer therefore actually accounted for $79 \%$ of the residual fraction of ANPP that had not been removed by mowing.

In heathlands, forage removal was similar in all study years, but ANPP was 36\% higher in 2017 than in the two preceding study years.

\section{Seasonal variation in productivity, standing biomass and forage removal}

In the different treatments in grasslands, the daily productivity rates peaked in the spring growth periods April-May or May-June (except for the M and B treatments in 2017 peaking in June-August) at 3.4 to $6.0 \mathrm{~g} \mathrm{~m}^{-2} \mathrm{~d}^{-1}$ (estimated marginal means; Fig. 1a, Table S4).

Generally, standing biomass levels were higher in the B and $\mathrm{U}$ treatment than in the M treatment (Fig. S3a, Table S4). In the B treatment, the standing biomass reached maximum annual values in August $(2015,2017)$ or August and October (2016). In the M treatment, peak standing biomass levels occurred in June $(2015,2017)$ or May and June (2016). In the $\mathrm{U}$ treatment, the standing biomass gradually increased over the three study years; peaked in June (2015) or August (2017) and was generally high from May to October 2016.

Table 1: Overview of mean standing biomass, aboveground net primary productivity (ANPP) and forage removal (dry weight, $\mathrm{g} \mathrm{m}^{-2}$ ) by red deer in grasslands and heathlands in Grafenwöhr military training area, Germany, in 2015-2017.

\begin{tabular}{|c|c|c|c|c|c|c|c|c|c|c|c|c|c|}
\hline & & \multicolumn{9}{|c|}{ Grasslands } & \multirow{2}{*}{\multicolumn{3}{|c|}{$\begin{array}{c}\text { Heathlands } \\
\text { Untreated }\end{array}$}} \\
\hline & & \multicolumn{3}{|c|}{ Burnt } & \multicolumn{3}{|c|}{ Mown } & \multicolumn{3}{|c|}{ Untreated } & & & \\
\hline & & 2015 & 2016 & 2017 & 2015 & 2016 & 2017 & 2015 & 2016 & 2017 & 2015 & 2016 & 2017 \\
\hline \multirow[t]{2}{*}{$\begin{array}{l}\text { Standing } \\
\text { biomass }\end{array}$} & Mean & 313.0 & 384.6 & 270.1 & 202.5 & 239.2 & 219.3 & 283.2 & 443.6 & 458.7 & 337.3 & 339.6 & 317.9 \\
\hline & SE & 15.0 & 19.6 & 17.3 & 17.0 & 21.5 & $\begin{array}{r}12.7 \\
12.7\end{array}$ & $\begin{array}{r}20.2 \\
17.2\end{array}$ & $\begin{array}{r}24.0 \\
24.5\end{array}$ & $\begin{array}{r}40.1 \\
15.6\end{array}$ & 17.3 & 11.6 & 15.0 \\
\hline \multirow[t]{2}{*}{ ANPP } & Mean & 412.3 & 357.5 & 437.9 & 495.4 & 476.3 & 398.8 & 396.3 & 422.9 & 293.2 & 215.1 & 225.1 & 300.0 \\
\hline & SE & 47.3 & 8.9 & 26.3 & 41.6 & 23.2 & 38.1 & 58.2 & 23.0 & 27.9 & 37.8 & 16.4 & 16.0 \\
\hline \multirow[t]{2}{*}{$\begin{array}{l}\text { Forage } \\
\text { removal }\end{array}$} & Mean & 160.7 & 82.0 & 180.8 & 185.2 & 224.5 & 191.8 & 184.2 & 178.8 & 169.6 & 141.5 & 130.1 & 164.0 \\
\hline & SE & 39.7 & 18.1 & 17.2 & 27.5 & 46.4 & 40.2 & 46.5 & 21.0 & 38.3 & 11.1 & 21.1 & 25.1 \\
\hline
\end{tabular}


In heathlands, the daily productivity peaked in 2016 and 2017 in the growth period April-May at 5.7 and $2.0 \mathrm{~g} \mathrm{~m}^{-2} \mathrm{~d}^{-1}$, respectively, and in 2015 in June-August at $0.8 \mathrm{~g} \mathrm{~m}^{-2} \mathrm{~d}^{-1}$ (Fig. 1b, Table S4). The standing biomass in heathlands was similar throughout the first study year, while peak values were reached in May 2016 and August 2017 (Fig. S3b, Table S4).
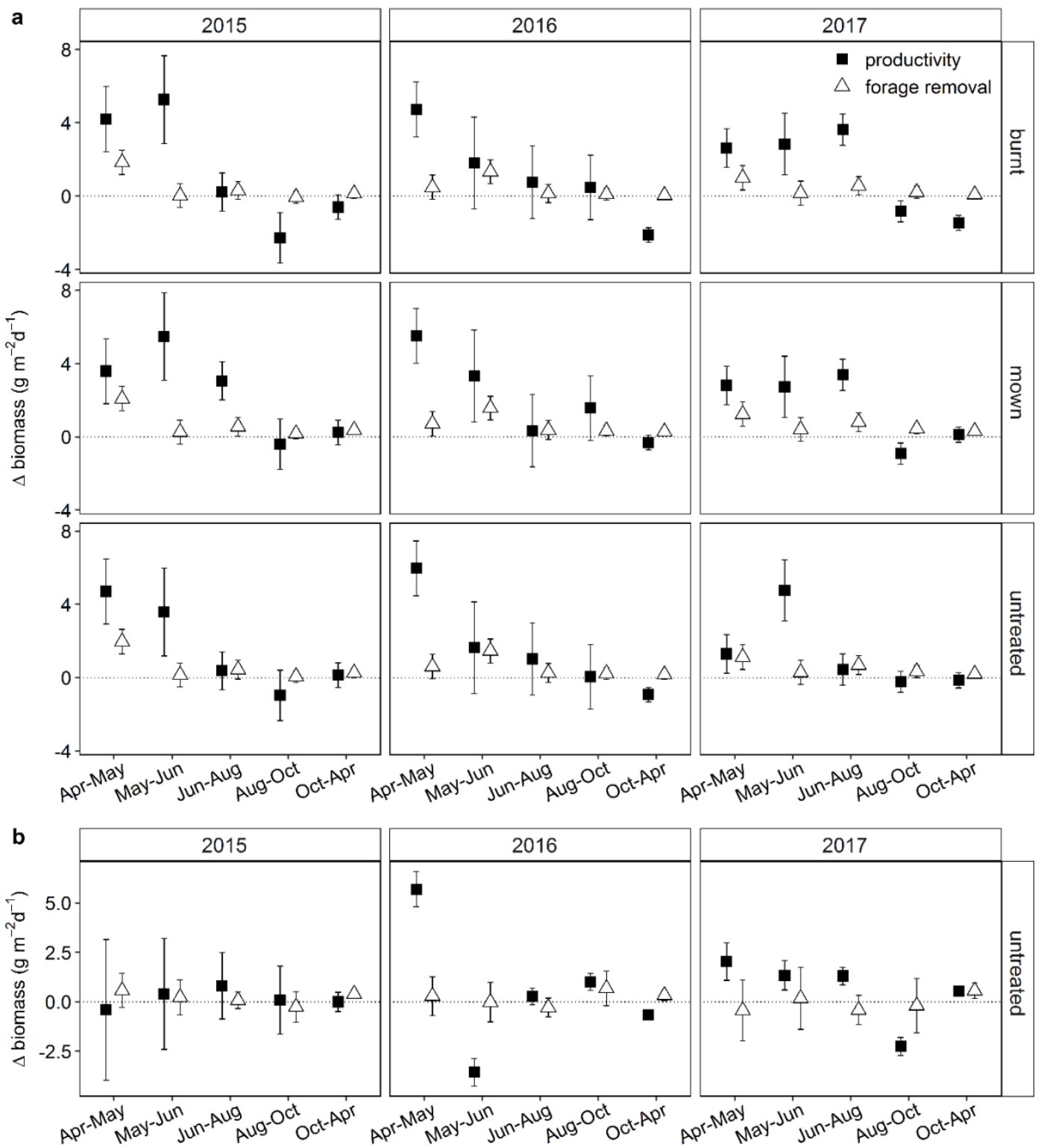

Figure 1: Daily rates of aboveground net primary productivity (dry matter) and red deer forage removal $\left(\mathrm{g} \mathrm{m}^{-2} \mathrm{~d}^{-1}\right)$ in (a) burnt, mown and untreated grasslands $(n=5)$; and (b) heathlands $(n=8)$ in 2015 to 2017. Symbols and lines show estimated marginal means and 95\% confidence interval based on the most parsimonious linear mixed effects models (Table S4) except for forage removal in heathlands, where the full model is shown because the simplified model did not include the factor year. 
The daily rates of red deer forage removal in grasslands were generally $58 \%$ higher in the $\mathrm{M}$ treatment than in the $\mathrm{B}$ treatment (averaging $0.71 \mathrm{~g} \mathrm{~m}^{-2} \mathrm{~d}^{-1}$ and $0.45 \mathrm{~g} \mathrm{~m}^{-2} \mathrm{~d}^{-1}$ in the $\mathrm{M}$ and $\mathrm{B}$ treatment, respectively) and intermediate in the $\mathrm{U}$ treatment. In 2015 and 2017, forage removal rates averaged over all grassland treatments peaked in April-May at $1.9 \mathrm{~g} \mathrm{~m}^{-2} \mathrm{~d}^{-1}$ and $1.1 \mathrm{~g} \mathrm{~m}^{-2} \mathrm{~d}^{-1}$, respectively, while in 2016 , forage removal was highest in May-June at $1.5 \mathrm{~g} \mathrm{~m}^{-2} \mathrm{~d}^{-1}$ (Table S4, Fig. 1a). In heathlands, forage removal rates peaked in all study years at $0.4 \mathrm{~g} \mathrm{~m}^{-2} \mathrm{~d}^{-1}$ in October-April, which was the only growth period when forage removal rates differed significantly from zero (Table S4, Fig. 1b).

\section{Forage quality}

In the $\mathrm{B}$ and $\mathrm{U}$ treatments in grasslands, forage quality decreased constantly in the course of the season in all study years, indicated by a decrease in CP from $15.3 \%$ in April to 7.6\% in October and an increase in oADF and oNDF from 31.5\% and $58.1 \%$ to $40.2 \%$ and $64.9 \%$, respectively (Fig. 2a, Table S5). By contrast, forage quality in the $\mathrm{M}$ treatment was distinctly higher than in the $\mathrm{B}$ or $\mathrm{U}$ treatment in August and October, with forage quality in August almost as good as in spring (CP, oADF and oNDF averaging $13.1 \%, 30.2 \%$ and $50.4 \%$ in the $\mathrm{M}$ treatment, respectively).

CP concentration in heathlands generally peaked with an average of $10.3 \%$ in May, although less pronounced in 2017 (Fig. 2b, Table S5), while oADF and oNDF were lowest in May or June at $35.0 \%$ and $54.8 \%$ on average, respectively. Depending on between-year variability, heathland forage quality was lowest in April or October with $\mathrm{CP}, \mathrm{oADF}$ and oNDF averaging $6.4 \%, 43.8 \%$ and $59.3 \%$, respectively.

\section{Forage removal in relation to environmental predictors}

The red deer daily forage removal rates in grasslands were positively related to the daily rates of productivity, but this relationship was moderated by year, growth period and treatment (Tables S6, S7). Generally, forage removal increased with productivity most strongly at the beginning of the growing season in April-May, but the relationship was also fairly pronounced at the end of the growing season in October-April. More precisely, averaged over treatments and years, a $1 \mathrm{~g} \mathrm{~m}^{-2} \mathrm{~d}^{-1}$ increase in productivity resulted in an increase in forage removal of up to 0.43 (October-April) or $0.48 \mathrm{~g} \mathrm{~m}^{-2} \mathrm{~d}^{-1}$ (April-May). Furthermore, the daily red deer forage removal rates increased with the concentration of $\mathrm{CP}$ in the grassland forage, i.e. across all treatments and growth periods, red deer forage removal increased by $0.28 \mathrm{~g} \mathrm{~m}^{-2} \mathrm{~d}^{-1}$ for each $1 \%$ increase in CP.

In heathlands, red deer daily forage removal rates did not relate to productivity, but there was a significant relationship between forage removal and the standing biomass at the beginning of the respective growth period. During most growth periods, forage removal rates increased with standing biomass. In October-April, when the daily forage removal in heathlands was significant, a $100 \mathrm{~g} \mathrm{~m}^{-2}$ increase in standing biomass did not substantially affect forage removal in 2015 but resulted in an increase of 5.6 and $5.8 \mathrm{~g} \mathrm{~m}^{-2} \mathrm{~d}^{-1}$ in daily forage removal in 2016 and 2017 , respectively. When including oADF as an additional explanatory variable for daily 
74 | Chapter 2

forage removal rates in heathlands, oADF replaced the experimental factor growth period as a single explanatory variable in the most parsimonious model. The distance between sampling plots and the nearest shrub or forest did not relate to red deer daily forage removal rates neither in grasslands nor heathlands.
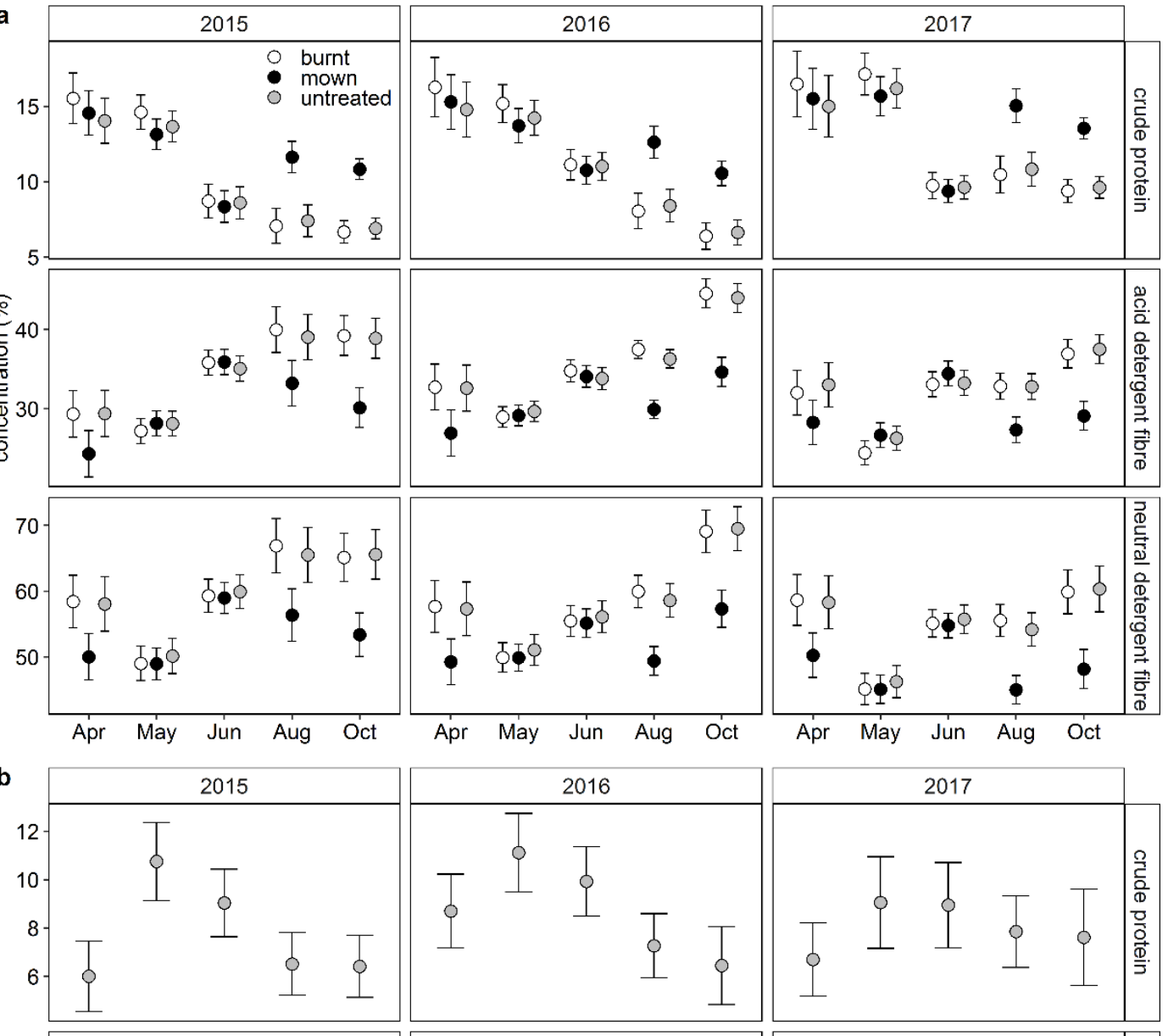

016
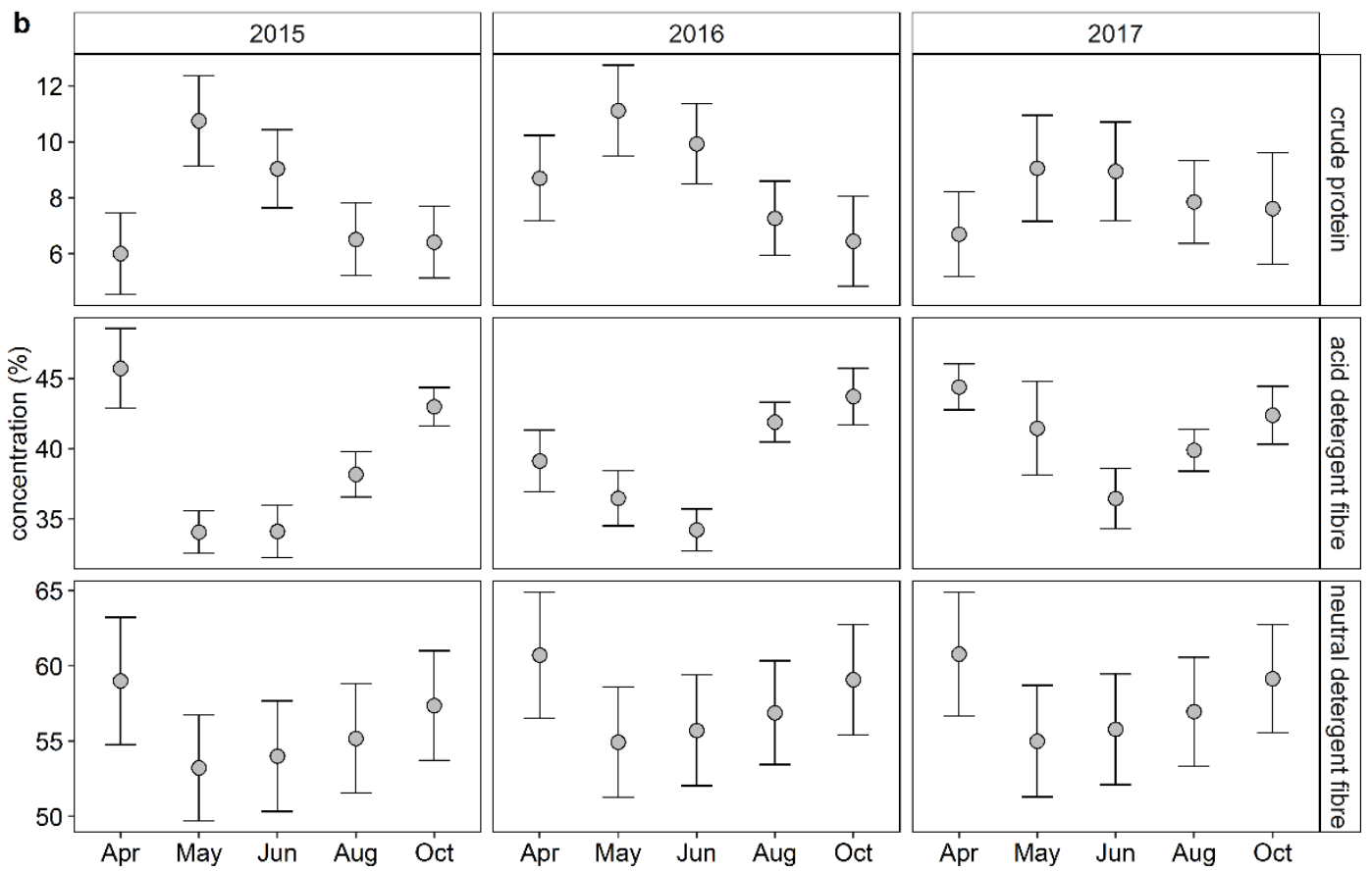

Figure 2: Concentration of crude protein and acid and neutral detergent fibre (exclusive of residual ash) in (a) burnt, mown and untreated grasslands $(n=5)$; and (b) heathlands $(n=8)$ in 2015 to 2017. Symbols and lines show estimated marginal means and $95 \%$ confidence interval based on the most parsimonious linear mixed effects models (Table S5). 


\section{Discussion}

Our data on productivity and biomass removal by red deer collected on a fine temporal scale over three successive years serve as a basis to judge the quantitative effect of grazing by a wild and free-ranging large herbivore species with regard to the grazing requirements of different semi-natural open habitat types. We found a comparable magnitude of annual forage removal by red deer in lowland hay meadows (82-225 $\mathrm{g} \mathrm{m}^{2} \mathrm{y}^{-1}$ ) and European dry heaths (130-164 $\mathrm{g} \mathrm{m}^{2} \mathrm{y}^{-1}$; Table 1), despite the different plant species composition, structure, phenology and productivity of these open habitat types.

Assuming that a standard animal unit (AU) requires $8.8 \mathrm{~kg}$ dry matter forage per day at maintenance level (Allen et al. 2011), the overall average annual forage removal by red deer in grasslands and heathlands amounts to the theoretical forage removal by 0.54 and $0.45 \mathrm{AU}$ per hectare, respectively. For extensive grazing of neutral grasslands, a stocking rate of $0.5 \mathrm{AU} \mathrm{ha}^{-1} \mathrm{y}^{-1}$ is recommended (Crofts and Jefferson 1999), while commonly used stocking rates for conservation grazing on lowland heathlands are highly variable $\left(0.03-0.50 \mathrm{AU} \mathrm{ha}^{-1} \mathrm{y}^{-1}\right)$ and strongly depend on the specific conservation aim (Gimingham 1992). Generally, this rough estimation of AU based on the observed forage removal substantiates that the quantity of forage biomass removed by free-ranging red deer can reach levels comparable to the amount of forage removed by livestock in conservation grazing (hypothesis 1) and is therefore relevant to the conservation of semi-natural open habitats. Future studies assessing the effect of red deer grazing on open habitat plant species richness and composition as well as their impact on the encroachment of woody species will be crucial for a comprehensive evaluation of wild red deer's potential in applied conservation.

\section{ANPP and forage removal by red deer in grasslands}

The ANPP of grasslands in the present study (293-495 $\left.\mathrm{g} \mathrm{m}^{-2} \mathrm{y}^{-1}\right)$ reflects the lack of fertilisation during the past decades of military land use in GTA and is therefore low compared to the productivity of agriculturally improved grasslands, and within the range of the productivity of unfertilized dry Arrhenatherum meadows (200$450 \mathrm{~g} \mathrm{~m}^{2} \mathrm{y}^{-1}$; Leuschner and Ellenberg 2017).

The share of the ANPP consumed by red deer in grasslands in GTA is in line with the few earlier studies that quantified forage removal by wild and free-ranging red deer. In the US Yellowstone National Park, forage removal by red deer and bison accounted for 22 to 58\% of the ANPP (Frank and McNaughton 1992). In a protected area in the Italian Pre-Alps, wild red deer consumed high amounts of biomass in agriculturally used mountain meadows, reaching up to $40 \%$ of the biomass at the second cut (Marchiori et al. 2012), and in south-eastern Slovenia, red deer grazing in grasslands close to forest borders reduced the herbage yield by $50 \%$ on average (Trdan and Vidrih 2007). 


\section{ANPP and forage removal by red deer in heatblands}

The ANPP of heathlands in GTA (215-300 $\left.\mathrm{g} \mathrm{m}^{-2} \mathrm{y}^{-1}\right)$ is higher than the productivity observed in northwest German inland heaths and similar to the productivity in British Calluna heathlands (Leuschner and Ellenberg 2017). Comparing the productivity between heathlands, however, is not straightforward because the Calluna life history phase strongly influences productivity rates (Barclay-Estrup 1970): The productivity of Calluna is low in the pioneer phase $\left(150 \mathrm{~g} \mathrm{~m}^{-2} \mathrm{y}^{-1}\right)$, peaks at $440 \mathrm{~g} \mathrm{~m}^{2} \mathrm{y}^{-1}$ in the building phase, and decreases from the mature phase $\left(360 \mathrm{~g} \mathrm{~m}^{-2} \mathrm{y}^{-1}\right)$ to the degenerate stage $\left(140 \mathrm{~g} \mathrm{~m}^{-2} \mathrm{y}^{-1}\right)$, while the standing biomass increases sharply from the pioneer $\left(290 \mathrm{~g} \mathrm{~m}^{-2}\right)$ over the building $\left(1510 \mathrm{~g} \mathrm{~m}^{-2}\right)$ to the mature phase $\left(1920 \mathrm{~g} \mathrm{~m}^{-2}\right)$ and declines towards the degenerate stage $\left(1040 \mathrm{~g} \mathrm{~m}^{-2}\right)$. The relatively high productivity of heathlands in GTA in conjunction with the low mean standing biomass (318-340 $\mathrm{g} \mathrm{m}^{-2}$ ) and the moderate Calluna cover (66\% on average over the study period; data not shown) hence suggest that GTA heathlands represent Calluna stands in an early building phase.

Interestingly, relative to the published data on Calluna height in the different life history phases (24-63 cm; Barclay-Estrup, 1970), the vegetation height was much lower throughout heathlands in GTA $(6.3 \pm 0.04 \mathrm{~cm}$; mean \pm SE over $3600 \mathrm{CSH}$ measurements during the three study years). From the considerable annual forage removal by red deer in heathlands, we deduce that grazing by red deer can prevent biomass accumulation and increasing vegetation height in heathlands. The divergent vegetation development inside additional permanent exclosures on our study sites (Fig. S5) provides further support for a profound retarding effect of red deer grazing on the Calluna life history cycle. Our results moreover corroborate that Calluna can thrive despite the removal of up to $60 \%$ of the annual production (Gimingham 1989).

\section{Seasonal variability in forage quality and forage removal by red deer}

Both the $\mathrm{B}$ and $\mathrm{U}$ treatment in grasslands showed opposing seasonal dynamics in $\mathrm{CP}$, on the one hand, and fibre components, on the other hand (Fig. 2a). Cervids strongly select for $\mathrm{CP}$ in forage, whereas fibre components, especially oADF, are often avoided owing to the portion of indigestible lignin (Felton et al. 2018). The attractiveness of forage in the $\mathrm{B}$ and $\mathrm{U}$ treatment hence continually decreased from spring to the end of the vegetation period. In the $\mathrm{M}$ treatment, by contrast, the forage quality was significantly higher in the late season after mowing. With regard to mowing, we can therefore confirm the first part of hypothesis (3) that additional management in grasslands improves forage quality.

The high rates of red deer forage removal detected in grasslands in spring and early summer corresponded to the high productivity and forage quality at the beginning of the vegetation period (Figs 1a, 2a). This temporal association was corroborated by significant positive linear relationships between daily forage removal in grasslands and productivity and CP, respectively (Tables S6, S7). The forage maturation hypothesis, widely supported in cervids (Fryxell 1991; Mysterud et al. 2017; Debeffe et al. 2017), can explain this seasonal pattern: red deer strongly select for vegetation in an early phenological stage because it offers easily digestible and highly nutritious 
forage. From a conservation point of view, high forage removal in grasslands during spring and early summer is essential to prevent the accumulation of unpalatable dead plant material (Crofts and Jefferson 1999) that grazing animals would reject in the later season and that could introduce changes in the plant community conflicting with conservation aims.

The forage maturation hypothesis, however, cannot explain that forage removal rates in heathlands were only significant during the winter period from October to April when neither productivity nor forage quality were high (Figs 1b, 2b). The diverging phenological development in heathlands and grasslands could illuminate this inconsistent pattern. Whereas grasslands offered forage of much better quality than heathlands in the early season, this difference vanished towards the end of the vegetation period. Consequently, the quality of the forage available to the red deer in heathlands during winter may be at least as good as in unmanaged grasslands, which made up the majority of open habitats in the surroundings of heathland plots (Table S1). The relatively high levels of yet ungrazed standing biomass at that time might additionally attract red deer (Fig. S3b), as indicated by the significant positive relationship between forage removal and the standing biomass in heathlands (Tables S6, S7). The observed forage removal in heathlands during the winter is in line with the results of faecal analyses of red deer in an Irish National Park, where Calluna was the major food component in winter when the quality of grasses was inferior (Sherlock and Fairley 1993). When forage quality is generally low as in the heathlands in our study, the quantity of potential forage biomass, rather than the quality, could be a driver for red deer foraging behaviour. Therefore, regarding hypothesis (2), we have to differentiate between grasslands, where seasonal changes in productivity and forage quality were reflected by seasonal patterns in red deer forage removal, and heathlands, where we did not detect a temporal association between productivity, forage quality and red deer forage removal.

\section{Management and drivers of forage removal by red deer}

While the annual forage removal of red deer indicated only by tendency that red deer foraged more in the $\mathrm{M}$ than in the $\mathrm{B}$ or $\mathrm{U}$ treatment (Table 1), we showed that the percent forage removal of the ANPP was $79 \%$ in the M treatment after subtracting the mown fraction from the ANPP. Hence, as assumed in hypothesis (3), mowing affected red deer forage removal. We explain this finding by the enhanced productivity and forage quality after the cut (Figs 1a, 2a) and the fact that red deer forage removal increased significantly with increasing productivity and CP (Tables S6, S7). Providing red deer with high-quality forage by mowing specific areas in their home range could, therefore, be an opportunity to influence their habitat use. In the Swiss Alps, a telemetry study similarly showed that farmed grassland could be an attractive and important food resource for free-ranging red deer and even suggested improving red deer access to open farmland to mitigate impacts on forests (ZweifelSchielly et al. 2012).

In contrast to mowing, which had a distinct effect on the ANPP, standing biomass and forage quality, the B treatment was less effective. One reason might be that burning partly failed in the first two study years. The reduced standing biomass at the 
first sampling date in April 2017 reflects that burning was more successful in the last study year, but further studies should explore the interactions between burning, productivity, forage quality and red deer grazing and judge potential benefits for grassland conservation in a Central European context.

Trdan and Vidrih (2007) suggested an association between forage removal by freeranging red deer and the distance from the forest border. In contrast, we did not detect a significant relationship between forage removal by red deer and the distance to shrub or forest cover. In the structurally heterogeneous open landscapes in GTA, distances to the next shrub or forest are generally small, so that the consequently low range of distances studied might have limited a potential effect of distance to cover on red deer forage intake. However, it is also likely that the wildlife management, especially via hunting, has contributed to this result. On Italian mountain meadows, forage intake by wild red deer did not consistently relate to the distance to the forest in different study years, which was attributed to a habituation effect of red deer to the lack of hunting pressure (Marchiori et al. 2012). In open areas in GTA, red deer are not disturbed by hunting for most of the year (Meißner et al. 2013). Accordingly, the use of open habitats for foraging by red deer in GTA is not as much influenced by the distance to cover as in other parts of Central Europe (Lone et al. 2015).

\section{Opportunities and challenges for conservation}

Our results seem very promising for a successful implementation of red deer grazing to conserve semi-natural open habitats because (i) forage removal by wild red deer was comparable in magnitude to the amount of forage removed by livestock in conservation grazing and (ii) in the two different open habitat types studied (lowland hay meadows and European dry heaths), red deer forage removal peaked in different seasons. In grasslands, red deer responded with high forage removal to the high productivity in the early season, presumably attracted by the high forage quality, whereas the grazing impact in heathlands was most pronounced in winter and not during the summer period when severe grazing could affect Calluna detrimentally (Gimingham 1989). Such flexibility in forage selection, characteristic of a herbivore with intermediate feeding strategy, cannot be expected from domestic herbivores, which mostly belong to the true roughage eaters (Hofmann 1989), so that red deer grazing could substantially advance current management options for semi-natural open habitat conservation. Especially for large target areas, for instance abandoned and active military training areas, core zones of national parks or other large nature reserves, red deer grazing could be a viable management opportunity. To that end, it is indispensable that the local hunting regime enables red deer to use open areas where grazing is considered beneficial, while deterring them from areas where it is not (Ciuti et al. 2012; Cromsigt et al. 2013).

In large-scale heterogeneous open landscapes, conservation management has to meet the challenge that different open habitat types require different grazing intensities and the proximity of a preferred plant community can increase the grazing impact of red deer on surrounding vegetation types (Palmer et al. 2003; Moore et al. 2015). Our results suggest that mowing of certain grassland areas, providing attractive forage in the late season, could be used to influence the habitat use of free-ranging red deer 
and thus manage grazing impacts in a spatially-explicit way. To preserve comparatively productive semi-natural habitats such as lowland hay meadows in the long run, biomass removal as achievable through wild, free-ranging red deer might not be sufficient, as indicated by a trend of biomass accumulation in our $\mathrm{U}$ treatment over the three study years (Fig. S3a). Therefore, combining red deer grazing with additional occasional and local management interventions, which could simultaneously serve as a leverage point for a targeted wildlife grazing management, might benefit the conservation of open habitats. In conclusion, we encourage attempts to modify current wildlife management strategies in large areas of conservation importance to allow red deer to forage in open landscapes, which could help to reduce damage in forest stands (Zweifel-Schielly et al. 2012; Jarnemo et al. 2014) and contribute to the conservation of semi-natural open habitats.

\section{Authors' contributions}

MM, BT, NB and JI developed the concept and design; FR collected data; FR and BT analysed and interpreted data, and FR wrote the manuscript. All authors contributed critically to the draft and gave final approval for publication.

\section{Data accessibility}

Data available via the Zenodo research data repository https://doi.org/10.5281/zenodo.2625737 (Riesch et al. 2019).

\section{Acknowledgements}

The project was supported by funds of German government's Special Purpose Fund held at Landwirtschaftliche Rentenbank [28 RZ 7007]. We thank the Federal Forests Division (Bundesforst) of the German Institute for Federal Real Estate (Bundesanstalt für Immobilienaufgaben) and the Institut für Wildbiologie Göttingen und Dresden e.V. for close cooperation and support. 


\section{References}

Allen VG, Batello C, Berretta EJ, Hodgson J, Kothmann M, Li X, McIvor J, Milne J, Morris C, Peeters A, Sanderson M. 2011. An international terminology for grazing lands and grazing animals. Grass and Forage Science 66:2-28.

Bakker ES, Gill JL, Johnson CN, Vera FWM, Sandom CJ, Asner GP, Svenning J-C. 2016. Combining paleo-data and modern exclosure experiments to assess the impact of megafauna extinctions on woody vegetation. Proceedings of the National Academy of Sciences 113:847-855.

Bakker ES, Ritchie ME, Olff H, Milchunas DG, Knops JMH. 2006. Herbivore impact on grassland plant diversity depends on habitat productivity and herbivore size. Ecology Letters 9:780788.

Barclay-Estrup P. 1970. The description and interpretation of cyclical processes in a heath community: II. Changes in biomass and shoot production during the Calluna cycle. The Journal of Ecology:243-249.

Borer ET, Seabloom EW, Gruner DS, Harpole WS, Hillebrand H, Lind EM, Adler PB, Alberti J, Anderson TM, Bakker JD, Biederman, L. 2014. Herbivores and nutrients control grassland plant diversity via light limitation. Nature 508:517-520.

Ciuti S, Northrup JM, Muhly TB, Simi S, Musiani M, Pitt JA, Boyce MS. 2012. Effects of Humans on Behaviour of Wildlife Exceed Those of Natural Predators in a Landscape of Fear. PLoS ONE 7:e50611.

Correll O, Isselstein J, Pavlu V. 2003. Studying spatial and temporal dynamics of sward structure at low stocking densities: the use of an extended rising-plate-meter method. Grass and Forage Science 58:450-454.

Crofts A, Jefferson RG, editors. 1999. The Lowland Grassland Management Handbook. 2nd ed. English Nature and Wildlife Trusts.

Cromsigt JPGM, Kuijper DPJ, Adam M, Beschta RL, Churski M, Eycott A, Kerley GIH, Mysterud A, Schmidt K, West K. 2013. Hunting for fear: innovating management of human-wildlife conflicts. Journal of Applied Ecology 50:544-549.

Cromsigt JPGM, Olff H. 2008. Dynamics of grazing lawn formation: an experimental test of the role of scale-dependent processes. Oikos 117:1444-1452.

Debeffe L, Rivrud IM, Brekkum Ø, Meisingset EL, Mysterud A. 2017. Implications of the forage maturation hypothesis for activity of partially migratory male and female deer. Ecosphere 8:e02050.

FAS. 2017. TN686: Conservation Grazing for Semi-Natural Habitats [Internet]. [cited 2018 Dec 11]. Available from: https://www.fas.scot/publication/tn686-conservation-grazing-semi-naturalhabitats/

Felton AM, Wam HK, Stolter C, Mathisen KM, Wallgren M. 2018. The complexity of interacting nutritional drivers behind food selection, a review of northern cervids. Ecosphere 9:e02230.

Fløjgaard C, De Barba M, Taberlet P, Ejrnæs R. 2017. Body condition, diet and ecosystem function of red deer (Cervus elapbus) in a fenced nature reserve. Global Ecology and Conservation 11:312-323.

Frank DA, McNaughton SJ. 1992. The Ecology of Plants, Large Mammalian Herbivores, and Drought in Yellowstone National Park. Ecology 73:2043-2058.

Fryxell JM. 1991. Forage quality and aggregation by large herbivores. American Naturalist:478-498.

Fuhlendorf SD, Engle DM, Kerby J, Hamilton R. 2009. Pyric Herbivory: Rewilding Landscapes through the Recoupling of Fire and Grazing. Conservation Biology 23:588-598.

García RR, Fraser MD, Celaya R, Ferreira LMM, García U, Osoro K. 2013. Grazing land management and biodiversity in the Atlantic European heathlands: a review. Agroforestry systems 87:19_ 43.

Gimingham CH. 1992. The Lowland Heathland Management Handbook. Peterborough, UK: English Nature.

Gordon IJ, Hester AJ, Festa-Bianchet M. 2004. REVIEW: The management of wild large herbivores to meet economic, conservation and environmental objectives. Journal of Applied Ecology 41:1021-1031.

Hofmann RR. 1989. Evolutionary steps of ecophysiological adaptation and diversification of ruminants: a comparative view of their digestive system. Oecologia 78:443-457. 
Hooftman DAP, Bullock JM. 2012. Mapping to inform conservation: A case study of changes in semi-natural habitats and their connectivity over 70 years. Biological Conservation 145:3038

Jarnemo A, Minderman J, Bunnefeld N, Zidar J, Månsson J. 2014. Managing landscapes for multiple objectives: alternative forage can reduce the conflict between deer and forestry. Ecosphere 5:1-14.

Langvatn R, Hanley TA. 1993. Feeding-patch choice by red deer in relation to foraging efficiency. Oecologia 95:164-170.

Leuschner C, Ellenberg H. 2017. Ecology of Central European Non-forest Vegetation: Coastal to Alpine, Natural to Man-made Habitats. Cham, CH: Springer.

Lone K, Loe LE, Meisingset EL, Stamnes I, Mysterud A. 2015. An adaptive behavioural response to hunting: surviving male red deer shift habitat at the onset of the hunting season. Animal Behaviour 102:127-138.

MacDougall AS, Turkington R. 2007. Does the Type of Disturbance Matter When Restoring Disturbance-Dependent Grasslands? Restoration Ecology 15:263-272.

Marchiori E, Sturaro E, Ramanzin M. 2012. Wild red deer (Cervus elaphus L.) grazing may seriously reduce forage production in mountain meadows. Italian Journal of Animal Science 11:e9.

McNaughton SJ, Milchunas DG, Frank DA. 1996. How can net primary productivity be measured in grazing ecosystems? Ecology 77:974-977.

Meißner M, Reinecke H, Herzog S. 2013. Vom Wald ins Offenland: Der Rothirsch auf dem Truppenübungsplatz Grafenwöhr. Raum-Zeit-Verhalten, Lebensraumnutzung, Management. 2nd ed. Kassel, DE: Frank Fornaçon.

Moore EK, Britton AJ, Iason G, Pemberton J, Pakeman RJ. 2015. Landscape-scale vegetation patterns influence small-scale grazing impacts. Biological Conservation 192:218-225.

Mysterud A, Vike BK, Meisingset EL, Rivrud IM. 2017. The role of landscape characteristics for forage maturation and nutritional benefits of migration in red deer. Ecology and Evolution $7: 4448-4455$.

Naturstiftung David. 2016. Naturschutz und Militär [Internet]. [cited 2018 Jan 4]. Available from: http://militaer.naturstiftung-david.de/start.php

Navarro LM, Pereira HM. 2012. Rewilding Abandoned Landscapes in Europe. Ecosystems 15:900912.

Palmer SCF, Hester AJ, Elston DA, Gordon IJ, Hartley SE. 2003. The perils of having tasty neighbors: grazing impacts of large herbivores at vegetation boundaries. Ecology 84:28772890.

Pinheiro J, Bates D, DebRoy S, Sarkar D, R Core Team. 2015. nlme: Linear and Nonlinear Mixed Effects Models. R package version 3.1-131 [Internet]. [cited 2016 Jan 14]. Available from: http://CRAN.R-project.org/package $=$ nlme

Poschlod P, Baumann A, Karlik P. 2009. Origin and development of grasslands in Central Europe. In: Grasslands in Europe of High Nature Value. Zeist, NL: KNNV Publishing; p. 15-25.

Poschlod P, WallisDeVries MF. 2002. The historical and socioeconomic perspective of calcareous grasslands-lessons from the distant and recent past. Biological Conservation 104:361-376.

Riesch F, Tonn B, Meißner M, Balkenhol N, Isselstein J (2019). Dataset accompanying Riesch et al. 2019. Grazing by wild red deer: Management options for the conservation of semi-natural open habitats. Journal of Applied Ecology [Internet]. Zenodo research data repository. https://doi.org/10.5281/zenodo.2625737.

Riesch F, Stroh HG, Tonn B, Isselstein J. 2018. Soil pH and phosphorus drive species composition and richness in semi-natural heathlands and grasslands unaffected by twentieth-century agricultural intensification. Plant Ecology \& Diversity 11:239-253.

Rivrud IM, Heurich M, Krupczynski P, Müller J, Mysterud A. 2016. Green wave tracking by large herbivores: an experimental approach. Ecology 97:3547-3553.

Rosenthal G, Schrautzer J, Eichberg C. 2012. Low-intensity grazing with domestic herbivores : a tool for maintaining and restoring plant diversity in temperate Europe. Tuexenia 32:167-205.

Sherlock MG, Fairley JS. 1993. Seasonal changes in the diet of red deer Cervus elaphus in the Connemara National Park. Biology and Environment: Proceedings of the Royal Irish Academy 93B:85-90. 
Svenning J-C, Pedersen PBM, Donlan CJ, Ejrnæs R, Faurby S, Galetti M, Hansen DM, Sandel B, Sandom CJ, Terborgh JW, Vera FWM. 2016. Science for a wilder Anthropocene: Synthesis and future directions for trophic rewilding research. Proceedings of the National Academy of Sciences 113:898-906.

Tälle M, Deák B, Poschlod P, Valkó O, Westerberg L, Milberg P. 2016. Grazing vs. mowing: A metaanalysis of biodiversity benefits for grassland management. Agriculture, Ecosystems \& Environment 222:200-212.

Taylor N, Knight JE, Short JJ. 2004. Fall Cattle Grazing versus Mowing to Increase Big-Game Forage. Wildlife Society Bulletin 32:449-455.

Trdan S, Vidrih M. 2007. Quantifying the damage of red deer (Cervus elaphus) grazing on grassland production in southeastern Slovenia. European Journal of Wildlife Research 54:138-141.

Tschöpe O, Wallschläger D, Burkart M, Tielbörger K. 2011. Managing open habitats by wild ungulate browsing and grazing: A case-study in North-Eastern Germany. Applied Vegetation Science 14:200-209.

Valkó O, Venn S, Żmihorski M, Biurrun I, Labadessa R, Loos J. 2018. The challenge of abandonment for the sustainable management of Palaearctic natural and semi-natural grasslands. Hacquetia 17:5-16.

Van Wieren SE. 1995. The potential role of large herbivores in nature conservation and extensive land use in Europe. Biological Journal of the Linnean Society 56:11-23.

Vera FWM. 2000. Grazing Ecology and Forest History. First edition. Wallingford, Oxon, NY: CABI.

Warren SD, Holbrook SW, Dale DA, Whelan NL, Elyn M, Grimm W, Jentsch A. 2007. Biodiversity and the Heterogeneous Disturbance Regime on Military Training Lands. Restoration Ecology 15:606-612.

Wesche K, Krause B, Culmsee H, Leuschner C. 2012. Fifty years of change in Central European grassland vegetation: Large losses in species richness and animal-pollinated plants. Biological Conservation 150:76-85.

Wilmshurst JF, Fryxell JM, Hudson RJ. 1995. Forage quality and patch choice by wapiti (Cervus elaphus). Behavioral Ecology 6:209-217.

Zweifel-Schielly B, Leuenberger Y, Kreuzer M, Suter W. 2012. A herbivore's food landscape: seasonal dynamics and nutritional implications of diet selection by a red deer population in contrasting Alpine habitats. Journal of Zoology 286:68-80. 


\section{Supporting Information to the paper}

Riesch et al. Grazing by wild red deer: Management options for the conservation of semi-natural open habitats. Journal of Applied Ecology.

\section{Appendices}

Appendix S1. Details on the assessment of standing biomass, aboveground net primary productivity and forage removal by wild red deer in Grafenwöhr military training area.

Appendix S2. Details on the forage quality analyses.

Supplementary tables

Table S1. Mean proportion (\%) of land cover classes in the surroundings of experimental plots.

Table S2. Results of models calibrating vegetation biomass to compressed sward height.

Table S3. Sequential Wald tests for the parameters in the most parsimonious models for standing biomass, annual aboveground net primary production and annual forage removal by red deer.

Table S4. Sequential Wald tests for the parameters in the most parsimonious models for daily rates of primary productivity and forage removal by red deer and standing biomass.

Table S5. Sequential Wald tests for the parameters in the most parsimonious models for crude protein, acid detergent fibre and neutral detergent fibre.

Table S6. Sequential Wald tests for the parameters in the most parsimonious models for daily forage removal by red deer including additional continuous environmental covariates.

Table S7. Slopes and 95\% confidence limits associated with the additional continuous environmental covariates in the most parsimonious models for red deer daily forage removal.

\section{Supplementary figures}

Fig. S1. Mean temperature and precipitation during the time of study in Grafenwöhr military training area in Bavaria, Germany.

Fig. S2. Location of the sampling sites in heathlands and grasslands at Grafenwöhr military training area in Bavaria, Germany.

Fig. S3. Standing biomass on experimental plots in 2015 to 2017.

Fig. S4. Movable exclusion cage.

Fig. S5. Additional permanent exclosure. 
Appendix S1: Details on the assessment of standing biomass, aboveground net primary productivity and forage removal by wild red deer in Grafenwöhr military training area

\section{Standing biomass and calibration models}

To assess the standing biomass in both heathlands and grasslands, we used a doublesampling technique relying on measurements of the compressed sward height by a rising-plate meter (30 cm disc diameter, $200 \mathrm{~g}$ disc weight) and calibration cuts (Correll et al. 2003). In each plot, we measured the sward height on 30 randomly distributed locations at five annual sampling dates (April, May, June, August and October) in three years (2015-2017). Additionally, we took two calibration cuts per plot, measuring the sward height on a $0.18 \mathrm{~m}^{2}$ area (two measurements) and cutting all vegetation to ground level. The calibration cut samples were weighed after drying at $105^{\circ} \mathrm{C}$ for at least 24 hours. We determined the relationship between calibration cut biomass (dry weight) and sward height by a linear model for each habitat and year (average adjusted $R^{2}$ of 0.81 and 0.67 for grasslands and heathlands, respectively; Table S2). Using these calibration models, we determined the standing biomass based on the mean over the 30 sward height measurements for each plot and sampling date.

\section{Aboveground net primary productivity}

Aboveground net primary productivity (ANPP) and forage removal by red deer were assessed by exclusion cages (Fig. S4), which were moved to a new position at each sampling date, i.e. five times per growing season, resulting in five growth periods per study year. Each time the exclusion cages were translocated, we measured the sward height under the cage (nine measurements; $1 \mathrm{~m}^{2}$ ) on the new and on the former cage position, respectively. Using the calibration models, we predicted the standing biomass at the old and new cage position for each sampling date based on the mean of the nine sward height measurements under the cage. To quantify the actual biomass growth during each growth period without biomass losses due to grazing, we calculated the difference in biomass under the cage between succeeding sampling dates. ANPP was calculated as the sum of the positive biomass increments under the cage over the five growth periods per year.

\section{Red deer forage removal}

To assess the forage removal by red deer, we calculated the increments of the standing biomass of the continuously grazed vegetation on the sampling plot between succeeding sampling dates. Red deer forage removal was then calculated as the difference in biomass increments of the vegetation temporarily protected from grazing (under the exclusion cage) and the continuously grazed vegetation (on the open plot). Analogously to ANPP, annual forage removal resulted from summing up positive forage removal values over the five growth periods per year. 
Appendix S2: Details on the forage quality analyses

On each sampling date (April, May, June, August and October; 2015 to 2017), we collected hand-pluck samples imitating red deer foraging behaviour to analyse forage quality as a potential driver of red deer foraging activity. We assessed total nitrogen concentration in plant material according to the Dumas combustion method in a $\mathrm{CN}$ elemental analyzer (vario MAX cube (in 2015), vario EL III (2016 and 2017), elementar, Langenselbold, DE). We multiplied total nitrogen by 6.25 to obtain crude protein (CP). Organic acid detergent fibre (exclusive of residual ash, oADF) and organic neutral detergent fibre (oNDF) in dried (at $60^{\circ} \mathrm{C}$ for at least 24 hours) and milled ( $1 \mathrm{~mm}$ grain size) hand-pluck samples were determined by near-infrared spectroscopy (NIRS) for grasslands and by wet-chemical analysis for heathlands. Grassland samples were scanned with a Foss NIRSystems 6500 spectrophometer (Foss NIRSystems, Silver Spring, MD, US) and spectra were calibrated using a wellestablished calibration function provided by the Institute VDLUFA Qualitätssicherung NIRS GmbH, Kassel, DE, which has proven valid for extensive grassland samples (Tillmann 2010). We additionally validated the NIRS results by wet-chemical analysis for a subset of 24 and 40 grassland samples in 2015 and 2016, respectively (oADF: $R^{2} \geq 0.94$; oNDF: $R^{2} \geq 0.92$ ). Because an equally valid calibration for heathland vegetation is lacking, heathland samples were processed according to the detergent fibre method (Van Soest et al. 1991) in an ANKOM fibre analyzer (ANKOM220, ANKOM Technology Corp., Macedon, NY, US). 
86 | Chapter 2

Table S1: Mean proportion (\%) of land cover classes in the surroundings of the experimental plots in grasslands and heathlands in Grafenwöhr military training area within a circular area of 488 ha, which corresponds to the average $95 \%$ minimum convex polygon home range size (mean of 34 annual home ranges of 24 female red deer in 2015-2018; L. Richter, unpublished). The proportion of land cover classes was calculated based on a Random-Forest-classification with 94.4\% Overall Accuracy (C. Raab, unpublished).

\begin{tabular}{|c|c|c|c|c|c|c|c|c|}
\hline & \multirow[t]{2}{*}{ Water } & \multirow[t]{2}{*}{ Heath } & \multicolumn{2}{|c|}{ Grassland } & \multicolumn{2}{|c|}{ Forest } & \multirow[t]{2}{*}{ Shrub } & \multirow[t]{2}{*}{ Other } \\
\hline & & & managed & unmanaged & deciduous & coniferous & & \\
\hline Grasslands & 0.34 & 0.03 & 19.04 & 37.65 & 13.28 & 9.53 & 10.30 & 9.82 \\
\hline Heathlands & 2.29 & 7.33 & 1.57 & 22.83 & 16.01 & 42.73 & 1.15 & 6.09 \\
\hline
\end{tabular}


Table S2: Results of the sequential analysis of variance for the most parsimonious linear models calibrating vegetation biomass (dry weight, $\mathrm{g} \mathrm{m}^{-2}$ ) to compressed sward height (CSH, $\mathrm{cm})$ for grasslands and heathlands in the three study years 2015 to 2017 including degrees of freedom $(d f)$, sums of squares (sum sq), F- and $p$-values and adjusted coefficient of determination $\left(R^{2}(\right.$ adj. $\left.)\right)$

\begin{tabular}{|c|c|c|c|c|c|c|c|c|}
\hline Habitat & Year & Parameter & $d f$ & sum sq & mean sum sq & F & $p$-value & $R_{\text {(adj.) }}^{2}$ \\
\hline \multirow[t]{27}{*}{ Grasslands } & \multirow[t]{10}{*}{2015} & $\mathrm{CSH}^{\mathrm{a}}$ & 1 & 4583782 & 4583782 & 1286.65 & $<0.001$ & \multirow[t]{10}{*}{0.83} \\
\hline & & $\mathrm{Cut}^{\mathrm{b}}$ & 1 & 52277 & 52277 & 14.67 & $<0.001$ & \\
\hline & & Treatment $^{c}$ & 2 & 124325 & 62162 & 17.45 & $<0.001$ & \\
\hline & & Sampl_dated & 5 & 626714 & 125343 & 35.18 & $<0.001$ & \\
\hline & & Sampl_site ${ }^{e}$ & 4 & 323605 & 80901 & 22.71 & $<0.001$ & \\
\hline & & $\mathrm{CSH} \times$ Treatment & 2 & 96547 & 48274 & 13.55 & $<0.001$ & \\
\hline & & CSH $\times$ Sampl_date & 5 & 168708 & 33742 & 9.47 & $<0.001$ & \\
\hline & & Treatment $\times$ Sampl_date & 10 & 156468 & 15647 & 4.39 & $<0.001$ & \\
\hline & & Sampl_date $\times$ Sampl_site & 20 & 327798 & 16390 & 4.60 & $<0.001$ & \\
\hline & & Residuals & 318 & 1132898 & 3563 & & & \\
\hline & \multirow[t]{9}{*}{2016} & $\mathrm{CSH}$ & 1 & 8914048 & 8914048 & 1294.87 & $<0.001$ & \multirow[t]{9}{*}{0.82} \\
\hline & & Treatment & 2 & 568188 & 284094 & 41.27 & $<0.001$ & \\
\hline & & Sampl_date & 5 & 714466 & 142893 & 20.76 & $<0.001$ & \\
\hline & & Sampl_site & 4 & 745686 & 186421 & 27.08 & $<0.001$ & \\
\hline & & $\mathrm{CSH} \times$ Treatment & 2 & 157211 & 78605 & 11.42 & $<0.001$ & \\
\hline & & CSH $\times$ Sampl_date & 5 & 328132 & 65626 & 9.53 & $<0.001$ & \\
\hline & & Treatment $\times$ Sampl_date & 10 & 395997 & 39600 & 5.75 & $<0.001$ & \\
\hline & & Sampl_date $\times$ Sampl_site & 20 & 386775 & 19339 & 2.81 & $<0.001$ & \\
\hline & & Residuals & 320 & 2202916 & 6884 & & & \\
\hline & \multirow[t]{8}{*}{2017} & $\mathrm{CSH}$ & 1 & 7315719 & 7315719 & 1015.01 & $<0.001$ & \multirow[t]{8}{*}{0.79} \\
\hline & & Cut & 1 & 53994 & 53994 & 7.49 & 0.007 & \\
\hline & & Treatment & 2 & 2069942 & 1034971 & 143.60 & $<0.001$ & \\
\hline & & Sampl_date & 5 & 178027 & 35605 & 4.94 & $<0.001$ & \\
\hline & & Sampl_site & 4 & 281809 & 70452 & 9.77 & $<0.001$ & \\
\hline & & CSH $\times$ Sampl_date & 5 & 222900 & 44580 & 6.19 & $<0.001$ & \\
\hline & & Treatment $\times$ Sampl_date & 10 & 279554 & 27955 & 3.88 & $<0.001$ & \\
\hline & & Residuals & 341 & 2457759 & 7208 & & & \\
\hline \multirow[t]{10}{*}{ Heathlands } & \multirow[t]{6}{*}{2015} & $\mathrm{CSH}$ & 1 & 2048807 & 2048807 & 356.22 & $<0.001$ & \multirow[t]{6}{*}{0.75} \\
\hline & & Sampl_date & 5 & 63087 & 12617 & 2.19 & 0.058 & \\
\hline & & Pairf & 7 & 207459 & 29637 & 5.15 & $<0.001$ & \\
\hline & & CSH $\times$ Sampl_date & 5 & 143045 & 28609 & 4.97 & $<0.001$ & \\
\hline & & Sampl_date $\times$ Pair & 35 & 1096222 & 31321 & 5.45 & $<0.001$ & \\
\hline & & Residuals & 136 & 782212 & 5752 & & & \\
\hline & \multirow[t]{4}{*}{2016} & Plot $^{g}$ & 1 & 51013 & 51013 & 5.23 & 0.023 & \multirow[t]{4}{*}{0.62} \\
\hline & & $\mathrm{CSH}$ & 1 & 1728899 & 1728899 & 177.18 & $<0.001$ & \\
\hline & & Sampl_date & 5 & 1156063 & 231213 & 23.69 & $<0.001$ & \\
\hline & & Plot $\times$ CSH & 1 & 100891 & 100891 & 10.34 & 0.002 & \\
\hline
\end{tabular}




\begin{tabular}{|c|c|c|c|c|c|c|c|c|}
\hline Habitat & Year & Parameter & $d f$ & sum sq & mean sum sq & $F$ & $p$-value & $R^{2}{ }_{(\text {adj.) }}$ \\
\hline & \multirow{8}{*}{2017} & $\mathrm{CSH} \times$ Sampl_date & 5 & 119867 & 23973 & 2.46 & 0.035 & \\
\hline & & Residuals & 178 & 1736909 & 9758 & & & \\
\hline & & Plot & 1 & 191297 & 191297 & 16.87 & $<0.001$ & 0.65 \\
\hline & & $\mathrm{CSH}$ & 1 & 2873789 & 2873789 & 253.37 & $<0.001$ & \\
\hline & & Sampl_date & 5 & 544309 & 108862 & 9.60 & $<0.001$ & \\
\hline & & Plot $\times \mathrm{CSH}$ & 1 & 346236 & 346236 & 30.53 & $<0.001$ & \\
\hline & & CSH $\times$ Sampl_date & 5 & 137060 & 27412 & 2.42 & 0.038 & \\
\hline & & Residuals & 178 & 2018931 & 11342 & & & \\
\hline
\end{tabular}

${ }^{a}$ Compressed sward height $(\mathrm{cm})$; continuous

${ }^{b}$ Grassland cut before sampling date; factor (Yes, No)

cTreatments in grasslands; factor (burnt, mown, untreated)

dSampling date; factor (April, May, June, August, October)

eSampling site; factor (five levels)

Pair of plots in heathlands; factor (eight levels)

sType of plot; factor (open, fenced)

To obtain consistent vegetation biomass data throughout the entire research project on Grafenwöhr military training area, the calibration models were built upon data from both the open plots, on which we investigated red deer grazing in the present study, as well as additional permanently fenced plots. Therefore, prior to AICc-based model selection, each global model for calibrating vegetation biomass (dry weight, $\left.\mathrm{g} \mathrm{m}^{-2}\right)$ to compressed sward height $(\mathrm{CSH}, \mathrm{cm})$ included the explanatory variable 'Plot'. The fenced plots were not the focus of the present study, so that the results from the predictions of the vegetation biomass for fenced plots were excluded from all present analyses.

In heathlands, study sites comprised only one treatment category (untreated) but either one or two pairs of open and fenced plots, so that 'Pair' instead of 'Treatment' was used as explanatory variable in heathlands. 
Table S3: Numerator $\left(d f_{\text {(num) }}\right)$ and denominator degrees of freedom $\left(d f_{\text {(den) })}\right), F$ - and $p$-values for sequential Wald tests for the parameters in the most parsimonious linear mixed effects models for standing biomass, annual aboveground net primary production (ANPP) and annual forage removal by red deer $\left(\mathrm{g} \mathrm{m}^{-2}\right)$ in grasslands and heathlands including each model's marginal $\left(R_{(m)}^{2}\right)$ and conditional coefficient of determination $\left(R^{2}(\mathrm{c})\right)$ according to Nakagawa and Schielzeth (2013).

\begin{tabular}{lllrrrrrr}
\hline Habitat type & Response & Parameter & $d f_{\text {(num) }}$ & $d f_{\text {(den) }}$ & \multicolumn{1}{l}{$F$} & $p$-value & $R^{2}(\mathrm{~m})$ & $R^{2}(\mathrm{c})$ \\
\hline Grasslands & Standing biomass & Year & 2 & 24 & 97.02 & $<0.001$ & 0.83 & 0.97 \\
& & Treatment & 2 & 8 & 264.64 & $<0.001$ & & \\
& & Year $\times$ Treatment & 4 & 24 & 57.03 & $<0.001$ & & \\
& \multirow{6}{*}{ ANPP } & Treatment & 2 & 8 & 9.17 & 0.009 & 0.55 & 0.55 \\
& Forage removal & Year & 2 & 28 & 18.19 & $<0.001$ & 0.44 & 0.94 \\
& Standing biomass & (Intercept) & 1 & 16 & 404.12 & $<0.001$ & 0.00 & 0.71 \\
& ANPP & Year & 2 & 14 & 4.85 & 0.025 & 0.22 & 0.48 \\
& Forage removal & (Intercept) & 1 & 16 & 121.50 & $<0.001$ & 0.00 & 0.56 \\
\hline
\end{tabular}


Table S4: Numerator $\left(d f_{\text {(num) }}\right)$ and denominator degrees of freedom $\left(d f f_{\text {(den) })}\right), F$ - and $p$-values for sequential Wald tests for the parameters in the most parsimonious linear mixed effects models for daily rates of primary productivity and forage removal by red deer $\left(\mathrm{g} \mathrm{m}^{-2} \mathrm{~d}^{-1}\right)$ and standing biomass $\left(\mathrm{g} \mathrm{m}^{-2}\right)$ in grasslands and heathlands including each model's marginal $\left(R^{2}(\mathrm{~m})\right)$ and conditional coefficient of determination $\left(R^{2}(\mathrm{c})\right)$ according to Nakagawa and Schielzeth (2013).

\begin{tabular}{|c|c|c|c|c|c|c|c|c|}
\hline Habitat type & Response & Parameter & $d f_{\text {(num) }}$ & $d f_{(\mathrm{den})}$ & $F$ & $p$-value & $R^{2}(\mathrm{~m})$ & $R^{2}(c)$ \\
\hline \multirow[t]{16}{*}{ Grasslands } & \multirow[t]{6}{*}{ Productivity } & Treatment & 2 & 8 & 80.10 & $<0.001$ & \multirow[t]{6}{*}{0.98} & \multirow[t]{6}{*}{0.99} \\
\hline & & Period & 4 & 168 & 261.93 & $<0.001$ & & \\
\hline & & Year $\times$ Treatment & 4 & 168 & 4.44 & 0.002 & & \\
\hline & & Year $\times$ Period & 8 & 168 & 21.44 & $<0.001$ & & \\
\hline & & Treatment $\times$ Period & 8 & 168 & 12.93 & $<0.001$ & & \\
\hline & & Year $\times$ Treatment $\times$ Period & 16 & 168 & 5.00 & $<0.001$ & & \\
\hline & \multirow[t]{4}{*}{ Forage removal } & Year & 2 & 196 & 23.38 & $<0.001$ & \multirow[t]{4}{*}{0.91} & \multirow[t]{4}{*}{0.95} \\
\hline & & Treatment & 2 & 8 & 4.57 & 0.011 & & \\
\hline & & Period & 4 & 196 & 10.68 & 0.006 & & \\
\hline & & Year $\times$ Period & 8 & 196 & 16.65 & $<0.001$ & & \\
\hline & \multirow[t]{6}{*}{ Standing biomass } & Year & 2 & 184 & 99.86 & $<0.001$ & \multirow[t]{6}{*}{0.82} & \multirow[t]{6}{*}{0.88} \\
\hline & & Treatment & 2 & 8 & 356.48 & $<0.001$ & & \\
\hline & & Month & 4 & 184 & 332.82 & $<0.001$ & & \\
\hline & & Year $\times$ Treatment & 4 & 184 & 77.00 & $<0.001$ & & \\
\hline & & Year $\times$ Month & 8 & 184 & 25.15 & $<0.001$ & & \\
\hline & & Treatment $\times$ Month & 8 & 184 & 34.49 & $<0.001$ & & \\
\hline \multirow[t]{7}{*}{ Heathlands } & \multirow[t]{3}{*}{ Productivity } & Year & 2 & 98 & 122.05 & $<0.001$ & \multirow[t]{3}{*}{0.23} & \multirow[t]{3}{*}{0.23} \\
\hline & & Period & 4 & 98 & 102.26 & $<0.001$ & & \\
\hline & & Year $\times$ Period & 8 & 98 & 74.43 & $<0.001$ & & \\
\hline & Forage removal & Period & 4 & 108 & 5.02 & 0.001 & 0.04 & 0.04 \\
\hline & \multirow[t]{3}{*}{ Standing biomass } & Year & 2 & 98 & 58.93 & $<0.001$ & \multirow[t]{3}{*}{0.13} & \multirow[t]{3}{*}{0.16} \\
\hline & & Month & 4 & 98 & 80.43 & $<0.001$ & & \\
\hline & & Year $\times$ Month & 8 & 98 & 22.69 & $<0.001$ & & \\
\hline
\end{tabular}


Table S5: Numerator $\left(d f_{\text {(num) }}\right)$ and denominator degrees of freedom $\left(d f_{\text {(den) }}\right), F$ - and $p$-values for Wald tests for the parameters in the most parsimonious linear mixed effects models for forage quality (CP, crude protein (\%); oADF, acid detergent fibre (\%); oNDF, neutral detergent fibre (\%)) in grasslands and heathlands including each model's marginal $\left(R^{2}(\mathrm{~m})\right)$ and conditional coefficient of determination $\left(R^{2}(c)\right)$ according to Nakagawa and Schielzeth (2013).

\begin{tabular}{|c|c|c|c|c|c|c|c|c|}
\hline Habitat type & Response & Parameter & $d f_{(\mathrm{num})}$ & $d f_{\text {(den) }}$ & $F$ & $p$-value & $R^{2}(\mathrm{~m})$ & $R^{2}(c)$ \\
\hline \multirow[t]{15}{*}{ Grasslands } & \multirow[t]{5}{*}{$\mathrm{CP}$} & Year & 2 & 188 & 33.69 & $<0.001$ & \multirow[t]{5}{*}{0.79} & \multirow[t]{5}{*}{0.80} \\
\hline & & Treatment & 2 & 8 & 71.07 & $<0.001$ & & \\
\hline & & Month & 4 & 188 & 266.27 & $<0.001$ & & \\
\hline & & Year $\times$ Month & 8 & 188 & 15.68 & $<0.001$ & & \\
\hline & & Treatment $\times$ Month & 8 & 188 & 37.07 & $<0.001$ & & \\
\hline & \multirow[t]{6}{*}{ oADF } & Year & 2 & 184 & 78.80 & $<0.001$ & \multirow[t]{6}{*}{0.71} & \multirow[t]{6}{*}{0.72} \\
\hline & & Treatment & 2 & 8 & 54.05 & $<0.001$ & & \\
\hline & & Month & 4 & 184 & 300.46 & $<0.001$ & & \\
\hline & & Year $\times$ Treatment & 4 & 184 & 10.10 & $<0.001$ & & \\
\hline & & Year $\times$ Month & 8 & 184 & 16.28 & $<0.001$ & & \\
\hline & & Treatment $\times$ Month & 8 & 184 & 43.67 & $<0.001$ & & \\
\hline & \multirow[t]{4}{*}{ oNDF } & Year & 2 & 188 & 47.37 & $<0.001$ & \multirow[t]{4}{*}{0.67} & \multirow[t]{4}{*}{0.69} \\
\hline & & Treatment & 2 & 8 & 23.96 & $<0.001$ & & \\
\hline & & Month & 4 & 188 & 146.46 & $<0.001$ & & \\
\hline & & Year $\times$ Month & 8 & 188 & 12.70 & $<0.001$ & & \\
\hline \multirow[t]{8}{*}{ Heathlands } & \multirow[t]{3}{*}{$\mathrm{CP}$} & Year & 8 & 188 & 120.30 & $<0.001$ & \multirow[t]{3}{*}{0.61} & \multirow[t]{3}{*}{0.88} \\
\hline & & Month & 4 & 98 & 120.26 & $<0.001$ & & \\
\hline & & Year $\times$ Month & 8 & 98 & 7.01 & $<0.001$ & & \\
\hline & \multirow[t]{3}{*}{$\mathrm{oADF}$} & Year & 2 & 98 & 24.40 & $<0.001$ & \multirow[t]{3}{*}{0.64} & \multirow[t]{3}{*}{0.65} \\
\hline & & Month & 4 & 98 & 109.31 & $<0.001$ & & \\
\hline & & Year $\times$ Month & 8 & 98 & 11.22 & $<0.001$ & & \\
\hline & \multirow[t]{2}{*}{ oNDF } & Year & 2 & 106 & 42.55 & $<0.001$ & \multirow[t]{2}{*}{0.07} & \multirow[t]{2}{*}{0.18} \\
\hline & & Month & 4 & 106 & 21.99 & $<0.001$ & & \\
\hline
\end{tabular}


Table S6: Numerator $\left(d f_{\text {(num) }}\right)$ and denominator degrees of freedom $\left(d f_{\text {(den) }}\right), F$ - and $p$-values for sequential Wald tests for the parameters retained in the most parsimonious linear mixed effects models for daily forage removal by red deer $\left(\mathrm{g} \mathrm{m}^{-2} \mathrm{~d}^{-1}\right)$ in grasslands and heathlands including daily productivity $\left(\mathrm{g} \mathrm{m}^{-2} \mathrm{~d}^{-1}\right)$, crude protein $(\mathrm{CP}, \%)$, standing biomass $\left(\mathrm{g} \mathrm{m}^{-2}\right)$ or acid detergent fibre (oADF, \%) as an additional continuous environmental covariate, respectively. $R^{2}(\mathrm{~m})$ and $R^{2}{ }_{(\mathrm{c})}$ show each model's marginal and conditional coefficient of determination according to Nakagawa and Schielzeth (2013).

\begin{tabular}{|c|c|c|c|c|c|c|c|c|}
\hline $\begin{array}{l}\text { Habitat } \\
\text { type }\end{array}$ & Covariate & Parameter & $d f_{\text {(num) }}$ & $d f_{\text {(den) }}$ & F & $p$-value & $\mathrm{R}_{(\mathrm{m})}^{2}$ & $R^{2}(c)$ \\
\hline \multirow[t]{14}{*}{ Grasslands } & \multirow[t]{10}{*}{ Productivity } & Productivity & 1 & 179 & 182.78 & $<0.001$ & \multirow[t]{10}{*}{0.94} & \multirow[t]{10}{*}{0.95} \\
\hline & & Year & 2 & 179 & 0.87 & 0.420 & & \\
\hline & & Treatment & 2 & 8 & 1.43 & 0.293 & & \\
\hline & & Period & 4 & 179 & 6.16 & 0.000 & & \\
\hline & & Productivity $\times$ Year & 2 & 179 & 13.59 & $<0.001$ & & \\
\hline & & Productivity $\times$ Treatment & 2 & 179 & 1.23 & 0.296 & & \\
\hline & & Productivity $\times$ Period & 4 & 179 & 8.42 & $<0.001$ & & \\
\hline & & Year $\times$ Treatment & 4 & 179 & 4.11 & 0.003 & & \\
\hline & & Year $\times$ Period & 8 & 179 & 13.73 & $<0.001$ & & \\
\hline & & Productivity $\times$ Year $\times$ Treatment & 4 & 179 & 4.84 & 0.001 & & \\
\hline & \multirow[t]{4}{*}{$\mathrm{CPa}^{\mathrm{a}}$} & Year & 2 & 195 & 0.23 & 0.798 & \multirow[t]{4}{*}{0.29} & \multirow[t]{4}{*}{0.30} \\
\hline & & Period & 4 & 195 & 13.73 & $<0.001$ & & \\
\hline & & $\mathrm{CP}$ & 1 & 195 & 10.52 & 0.001 & & \\
\hline & & Year $\times$ Period & 8 & 195 & 6.13 & $<0.001$ & & \\
\hline \multirow[t]{6}{*}{ Heathlands } & \multirow[t]{5}{*}{ Biomass $^{a}$} & Biomass & 1 & 99 & 30.98 & $<0.001$ & \multirow[t]{6}{*}{0.12} & \multirow[t]{6}{*}{0.13} \\
\hline & & Year & 2 & 99 & 4.08 & 0.020 & & \\
\hline & & Period & 4 & 99 & 9.22 & $<0.001$ & & \\
\hline & & Biomass $\times$ Year & 2 & 99 & 17.97 & $<0.001$ & & \\
\hline & & Biomass $\times$ Period & 4 & 99 & 4.45 & 0.002 & & \\
\hline & oADFa & oADF & 1 & 111 & 12.02 & 0.001 & & \\
\hline
\end{tabular}

${ }^{a}$ Measured at the beginning of the respective growth period 
Table S7: Slopes and 95\% confidence limits (CL) associated with the additional continuous environmental covariates in the most parsimonious linear mixed effects models explaining red deer daily forage removal $\left(\mathrm{g} \mathrm{m}^{-2} \mathrm{~d}^{-1}\right)$. Daily productivity $\left(\mathrm{g} \mathrm{m}^{-2} \mathrm{~d}^{-1}\right)$ and crude protein (\%) were retained as significant covariates in the models for forage removal in grasslands, while standing biomass $\left(\mathrm{g} \mathrm{m}^{-2}\right)$ and acid detergent fibre (oADF, \%) were significant for forage removal in heathlands (cf. Table S6).

\begin{tabular}{|c|c|c|c|c|c|c|c|}
\hline \multirow{2}{*}{$\frac{\text { Habitat type }}{\text { Grasslands }}$} & \multirow{2}{*}{$\frac{\text { Covariate }}{\text { Productivity }}$} & \multirow{2}{*}{$\begin{array}{l}\text { Treatment } \\
\text { Burnt }\end{array}$} & \multirow{2}{*}{$\frac{\text { Year }}{2015}$} & \multicolumn{2}{|c|}{ Growth period Slope } & \multicolumn{2}{|c|}{ Lower CL Upper CL } \\
\hline & & & & Apr15-May15 & 0.5096 & 0.3199 & 0.4167 \\
\hline & & & 2016 & Apr16-May16 & 0.2931 & 0.0829 & 0.1901 \\
\hline & & & 2017 & Apr17-May17 & 0.6293 & 0.4282 & 0.5308 \\
\hline & & Mown & 2015 & Apr15-May15 & 0.3919 & 0.1854 & 0.2908 \\
\hline & & & 2016 & Apr16-May16 & 0.4489 & 0.2484 & 0.3507 \\
\hline & & & 2017 & Apr17-May17 & 0.8146 & 0.5978 & 0.7084 \\
\hline & & Untreated & 2015 & Apr15-May15 & 0.4871 & 0.2739 & 0.3827 \\
\hline & & & 2016 & Apr16-May16 & 0.4608 & 0.2507 & 0.3579 \\
\hline & & & 2017 & Apr17-May17 & 0.6688 & 0.4289 & 0.5513 \\
\hline & & Burnt & 2015 & May15-Jun15 & 0.2194 & 0.0604 & 0.1415 \\
\hline & & & 2016 & May16-Jun16 & 0.0028 & -0.1713 & -0.0825 \\
\hline & & & 2017 & May17-Jun17 & 0.3391 & 0.1688 & 0.2557 \\
\hline & & Mown & 2015 & May15-Jun15 & 0.1017 & -0.0590 & 0.0230 \\
\hline & & & 2016 & May16-Jun16 & 0.1586 & -0.0142 & 0.0740 \\
\hline & & & 2017 & May17-Jun17 & 0.5243 & 0.3328 & 0.4305 \\
\hline & & Untreated & 2015 & May15-Jun15 & 0.1969 & -0.0073 & 0.0969 \\
\hline & & & 2016 & May16-Jun16 & 0.1706 & -0.0164 & 0.0790 \\
\hline & & & 2017 & May17-Jun17 & 0.3785 & 0.1950 & 0.2886 \\
\hline & & Burnt & 2015 & Jun15-Aug15 & 0.1099 & -0.0614 & 0.0260 \\
\hline & & & 2016 & Jun16-Aug16 & -0.1067 & -0.2720 & -0.1877 \\
\hline & & & 2017 & Jun17-Aug17 & 0.2296 & 0.1096 & 0.1708 \\
\hline & & Mown & 2015 & Jun15-Aug15 & -0.0078 & -0.1909 & -0.0975 \\
\hline & & & 2016 & Jun16-Aug16 & 0.0491 & -0.1265 & -0.0369 \\
\hline & & & 2017 & Jun17-Aug17 & 0.4148 & 0.2459 & 0.3321 \\
\hline & & Untreated & 2015 & Jun15-Aug15 & 0.0874 & -0.1183 & -0.0134 \\
\hline & & & 2016 & Jun16-Aug16 & 0.0611 & -0.1174 & -0.0263 \\
\hline & & & 2017 & Jun17-Aug17 & 0.2690 & 0.0688 & 0.1709 \\
\hline & & Burnt & 2015 & Aug15-Oct15 & 0.1011 & -0.0346 & 0.0346 \\
\hline & & & 2016 & Aug16-Oct16 & -0.1154 & -0.2496 & -0.1811 \\
\hline & & & 2017 & Aug17-Oct17 & 0.2208 & 0.0707 & 0.1473 \\
\hline & & Mown & 2015 & Aug15-Oct15 & -0.0166 & -0.1670 & -0.0903 \\
\hline & & & 2016 & Aug16-Oct16 & 0.0404 & -0.0771 & -0.0172 \\
\hline & & & 2017 & Aug17-Oct17 & 0.4061 & 0.2360 & 0.3228 \\
\hline & & Untreated & 2015 & Aug15-Oct15 & 0.0786 & -0.1013 & -0.0095 \\
\hline & & & 2016 & Aug16-Oct16 & 0.0523 & -0.1035 & -0.0240 \\
\hline & & & 2017 & Aug17-Oct17 & 0.2602 & 0.0651 & 0.1647 \\
\hline
\end{tabular}




\begin{tabular}{|c|c|c|c|c|c|c|c|}
\hline \multirow[t]{2}{*}{ Habitat type } & \multirow[t]{2}{*}{ Covariate } & \multirow{2}{*}{$\begin{array}{l}\text { Treatment } \\
\text { Burnt }\end{array}$} & \multirow{2}{*}{$\frac{\text { Year }}{2015}$} & \multicolumn{2}{|c|}{ Growth period Slope } & \multicolumn{2}{|c|}{ Lower CL Upper CL } \\
\hline & & & & Oct15-Apr16 & 0.3978 & 0.2714 & 0.3359 \\
\hline & & & 2016 & Oct16-Apr17 & 0.1813 & 0.0490 & 0.1165 \\
\hline & & & 2017 & Oct17-Apr18 & 0.5175 & 0.3991 & 0.4595 \\
\hline & & Mown & 2015 & Oct15-Apr16 & 0.2801 & 0.1268 & 0.2050 \\
\hline & & & 2016 & Oct16-Apr17 & 0.3371 & 0.1730 & 0.2567 \\
\hline & & & 2017 & Oct17-Apr18 & 0.7028 & 0.5339 & 0.6200 \\
\hline & & Untreated & 2015 & Oct15-Apr16 & 0.3753 & 0.1983 & 0.2886 \\
\hline & & & 2016 & Oct16-Apr17 & 0.3490 & 0.1769 & 0.2647 \\
\hline & & & 2017 & Oct17-Apr18 & 0.5569 & 0.3691 & 0.4649 \\
\hline & \multicolumn{2}{|l|}{ Crude protein ${ }^{\mathrm{a}}$} & & & 0.2755 & 0.1261 & 0.2023 \\
\hline \multirow[t]{16}{*}{ Heathlands } & Biomass $^{a}$ & Untreated & 2015 & Apr15-May15 & 0.0031 & -0.0008 & 0.0012 \\
\hline & & & 2016 & Apr16-May16 & 0.0087 & 0.0045 & 0.0066 \\
\hline & & & 2017 & Apr17-May17 & 0.0089 & 0.0049 & 0.0069 \\
\hline & & & 2015 & May15-Jun15 & -0.0022 & -0.0070 & -0.0046 \\
\hline & & & 2016 & May16-Jun16 & 0.0034 & -0.0013 & 0.0011 \\
\hline & & & 2017 & May17-Jun17 & 0.0037 & -0.0013 & 0.0012 \\
\hline & & & 2015 & Jun15-Aug15 & 0.0029 & 0.0007 & 0.0018 \\
\hline & & & 2016 & Jun16-Aug16 & 0.0085 & 0.0054 & 0.0070 \\
\hline & & & 2017 & Jun17-Aug17 & 0.0087 & 0.0053 & 0.0070 \\
\hline & & & 2015 & Aug15-Oct15 & -0.0044 & -0.0075 & -0.0059 \\
\hline & & & 2016 & Aug16-Oct16 & 0.0012 & -0.0026 & -0.0006 \\
\hline & & & 2017 & Aug17-Oct17 & 0.0015 & -0.0024 & -0.0004 \\
\hline & & & 2015 & Oct15-Apr16 & 0.0000 & -0.0017 & -0.0008 \\
\hline & & & 2016 & Oct16-Apr17 & 0.0056 & 0.0037 & 0.0046 \\
\hline & & & 2017 & Oct17-Apr18 & 0.0058 & 0.0034 & 0.0046 \\
\hline & oADFa & Untreated & & & 0.0351 & 0.0152 & 0.0254 \\
\hline
\end{tabular}

${ }^{a}$ Measured at the beginning of the respective growth period 


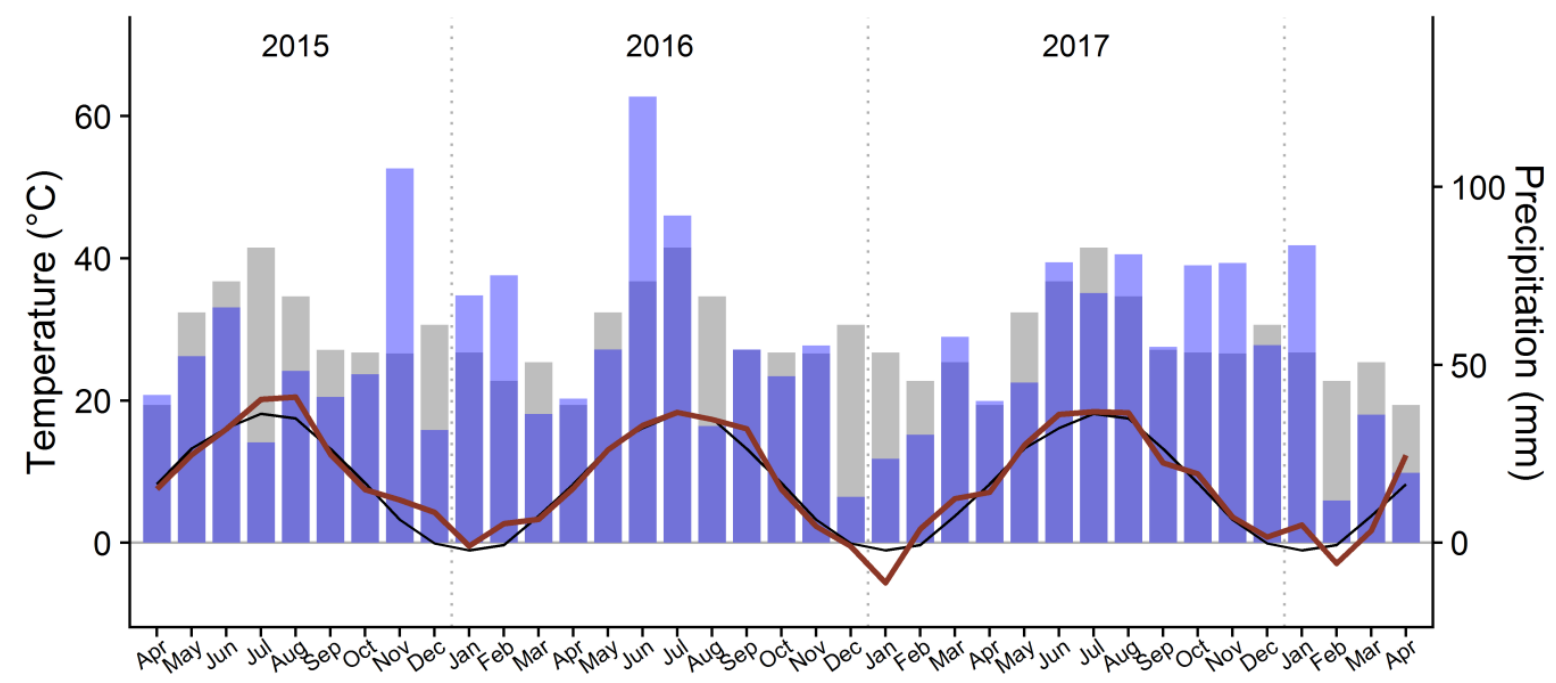

Figure S1: Mean temperature $\left({ }^{\circ} \mathrm{C}\right.$, blue bars) and precipitation ( $\mathrm{mm}$, red line) during the time of study, April 2015 to April 2017, in Grafenwöhr military training area in Bavaria, Germany (averaged over four weather stations of the German Weather Service (Deutscher Wetterdienst, DWD) in the immediate vicinity). The grey bars and the black line show the 1981-2010 long-term average temperature and precipitation, respectively. 


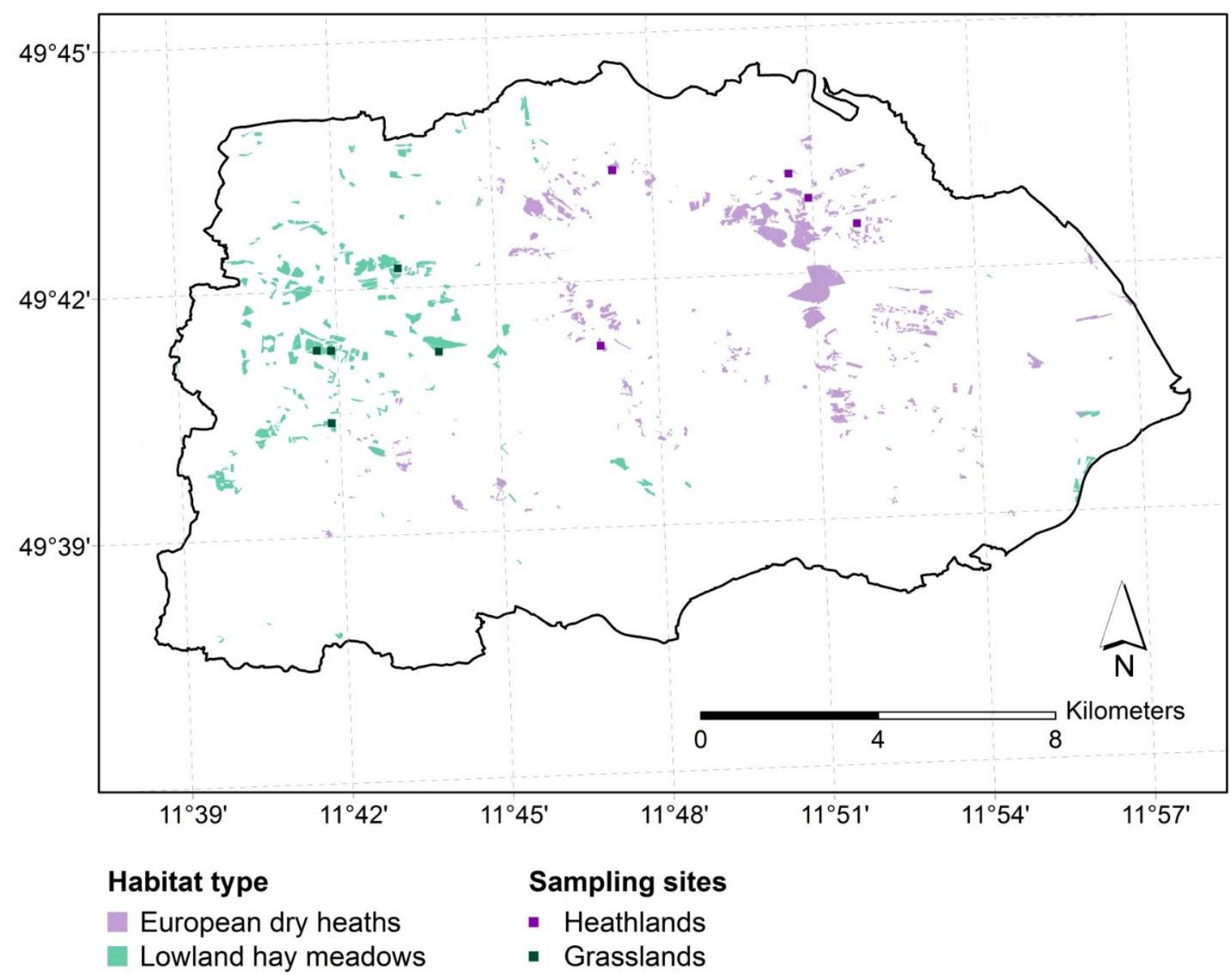

Figure S2: Location of the sampling sites in heathlands and grasslands at Grafenwöhr military training area in Bavaria, Germany. Shaded areas indicate the occurrence of the Natura 2000 habitat types 4030, European dry heaths, and 6510, lowland hay meadows, according to the draft of the Natura 2000 management plan (2013/2014) for the Site of Community Importance and Special Area of Conservation US-Truppenübungsplatz Grafenwöhr (DE6336301). Adapted from Riesch et al. (2018). 


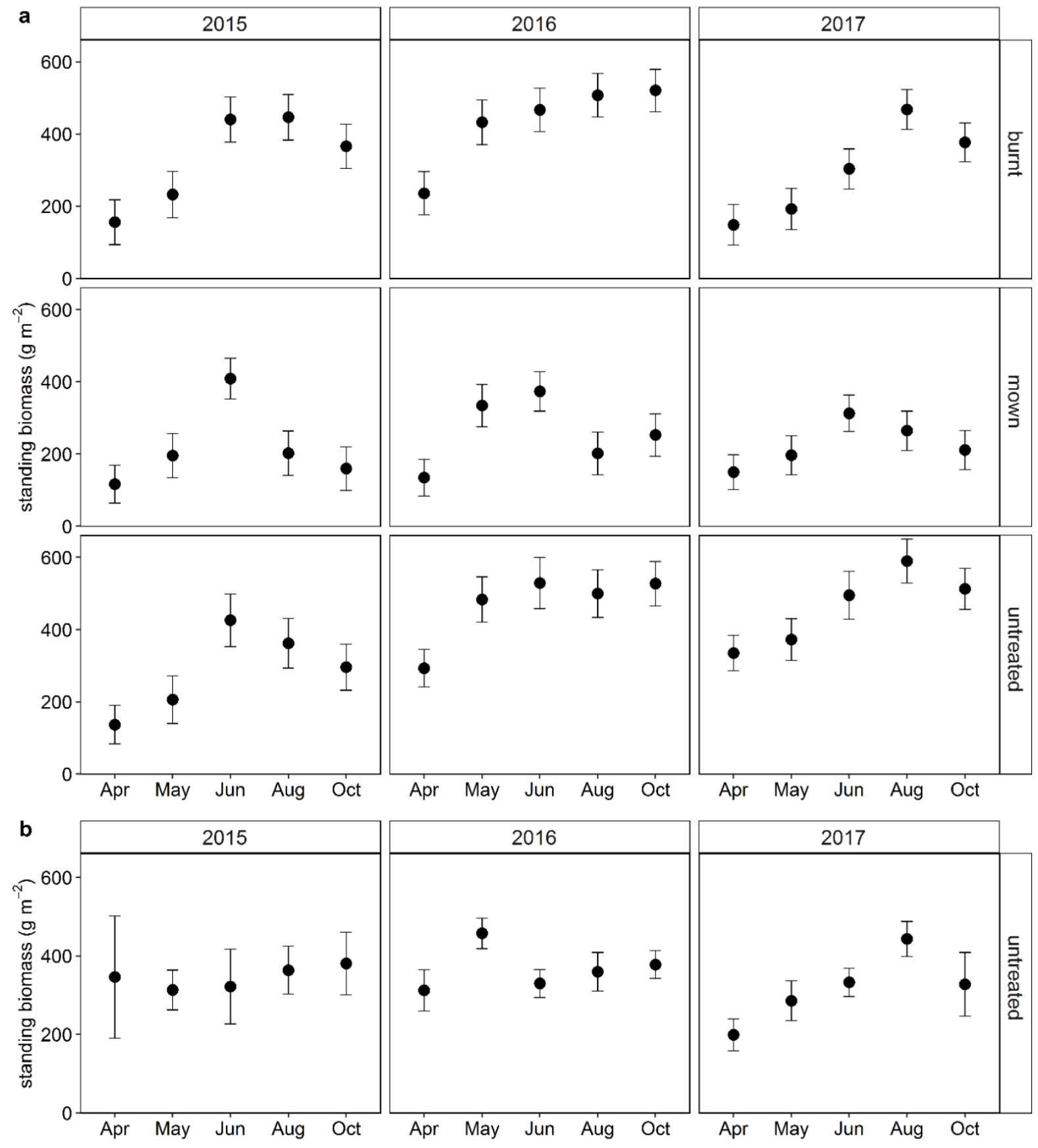

Figure S3: Standing biomass (dry matter, $\mathrm{g} \mathrm{m}^{-2}$ ) in (a) burnt, mown and untreated grasslands $(n=5)$; and (b) heathlands $(n=8)$ in 2015 to 2017. Symbols and lines show estimated marginal means and 95\% confidence interval based on linear mixed effects models. 
98 Chapter 2

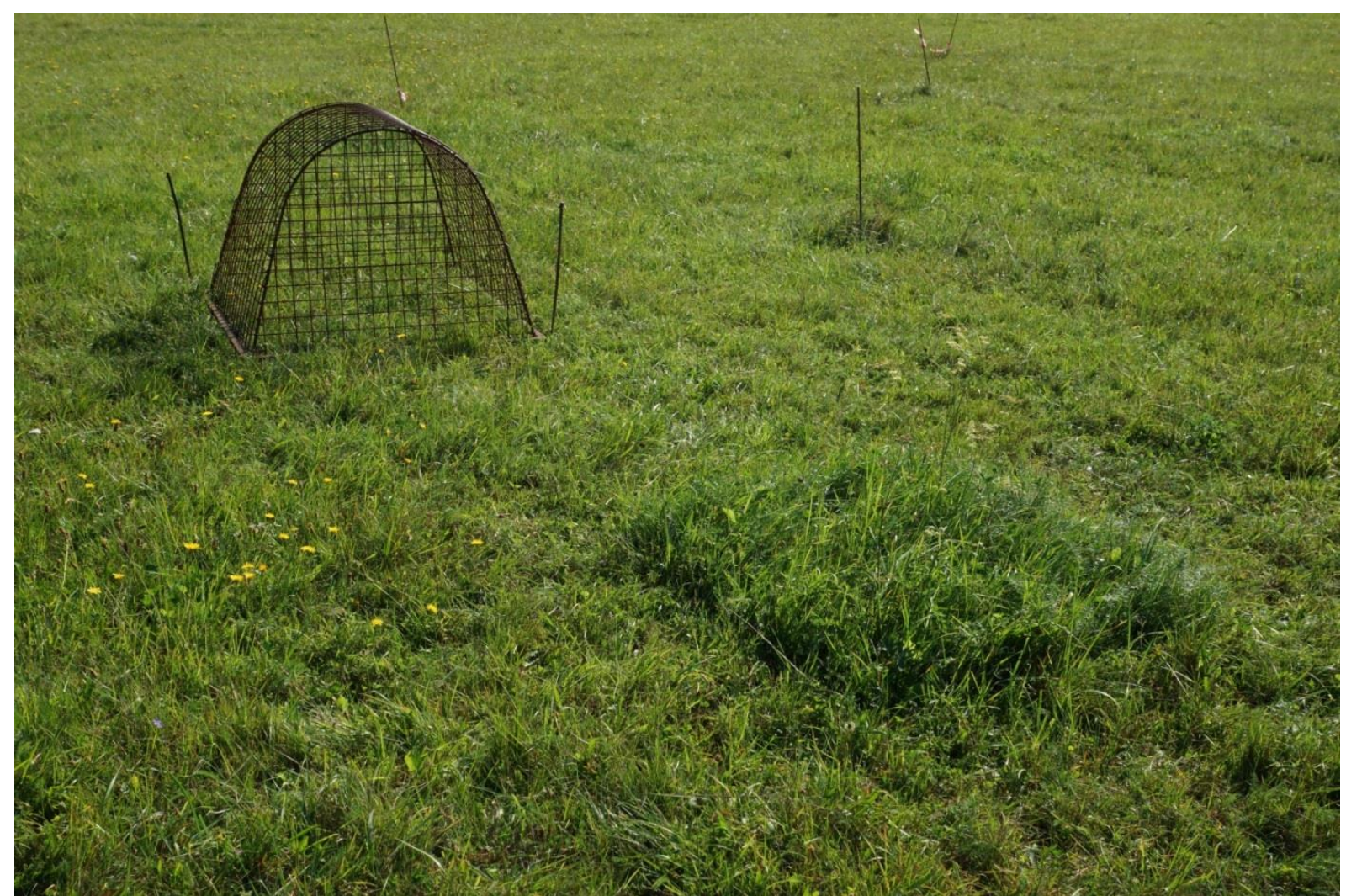

Figure S4: Movable exclusion cage after translocation to a new position. The former cage position is clearly recognizable by the square of taller, ungrazed vegetation. Picture taken in August 2016 (Anya Wichelhaus). 


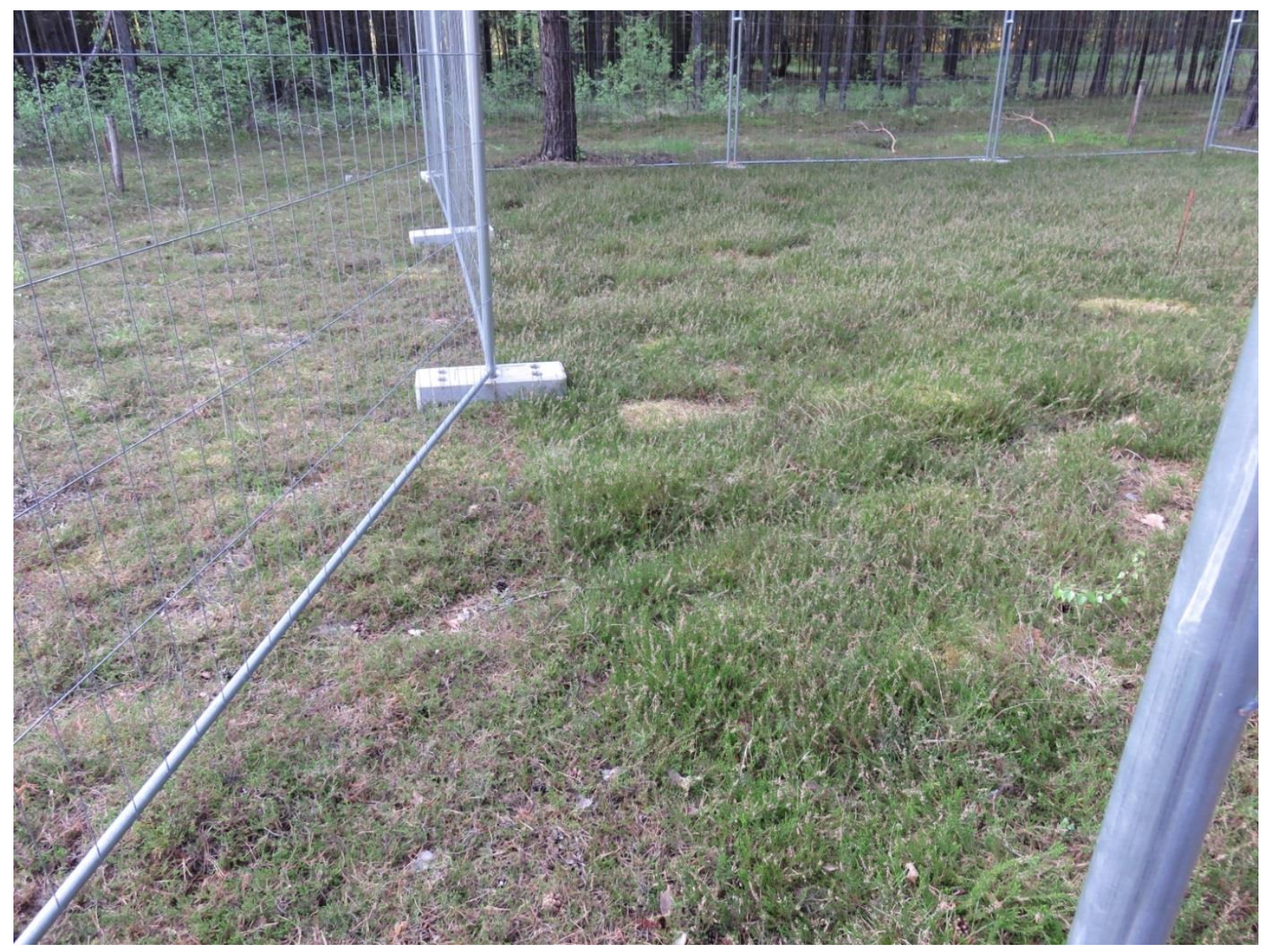

Figure S5: Exemplary additional permanent exclosure preventing red deer grazing in heathlands. The picture was taken in May 2016, 20 months after the fence was installed. 


\section{References (Supporting Information)}

Correll O, Isselstein J, Pavlu V. 2003. Studying spatial and temporal dynamics of sward structure at low stocking densities: the use of an extended rising-plate-meter method. Grass and Forage Science 58:450-454.

Nakagawa S, Schielzeth H. 2013. A general and simple method for obtaining $\mathrm{R}^{2}$ from generalized linear mixed-effects models. Methods in Ecology and Evolution 4:133-142.

Riesch F, Stroh HG, Tonn B, Isselstein J. 2018. Soil pH and phosphorus drive species composition and richness in semi-natural heathlands and grasslands unaffected by twentieth-century agricultural intensification. Plant Ecology \& Diversity 11:239-253.

Tillmann P. 2010. Anwendung der Nahinfrarotspektroskopie (NIRS) an Grünlandproben. VDLUFASchriftenreihe 66:145-150.

Van Soest PJ, Robertson JB, Lewis BA. 1991. Methods for Dietary Fibre, Neutral Detergent Fibre, and Nonstarch Polysaccharides in Relation to Animal Nutrition. Journal of Dairy Science 74:3583-3597. 


\section{Chapter 3}

Grazing by wild red deer maintains characteristic vegetation of semi-natural open habitats: Evidence from a 3-year exclusion experiment

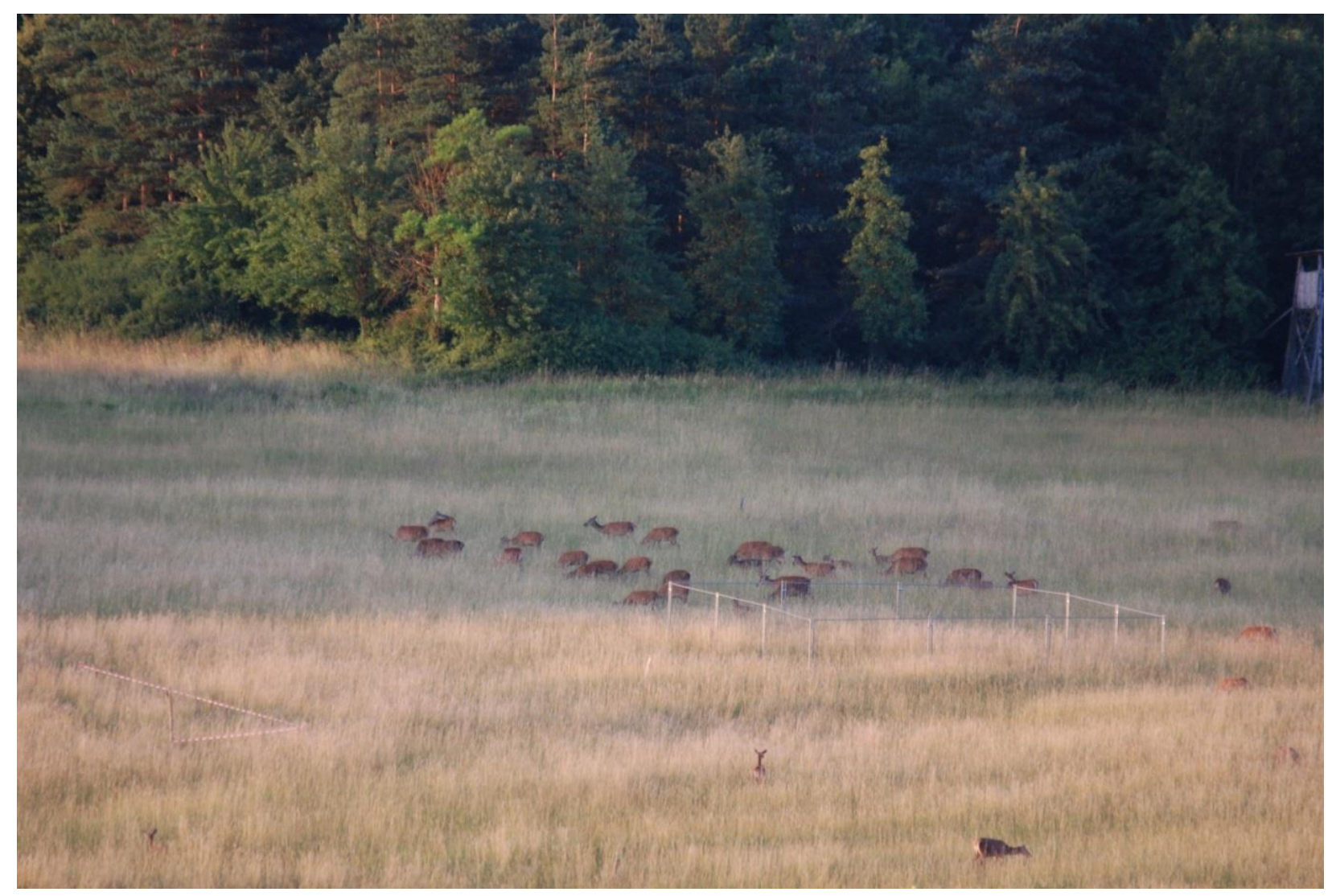

Picture: Marcus Meißner

This chapter is submitted as:

Riesch F, Stroh HG, Tonn B, Meißner M, Balkenhol N, Isselstein J. Grazing by wild red deer maintains characteristic vegetation of semi-natural open habitats: Evidence from a 3-year exclusion experiment. Applied Vegetation Science. 


\begin{abstract}
Conservation management of semi-natural open habitats today has to compensate for the decline of traditional practices of agricultural land use. We studied if wild and free-ranging red deer contribute to the preservation of characteristic open habitat plant communities. On a military training area in Germany, we set up a grazing exclusion experiment in grasslands (lowland hay meadows) and heathlands (European dry heaths) and monitored structural vegetation characteristics (sward height, bare soil, biomass contribution of Calluna vulgaris, litter height, woody species individuals) in open and fenced plots within a 3-year study period. We compared plant species richness, diversity and community composition before and after the experimental period. In grasslands, plant species diversity was significantly reduced in fenced compared to open plots and in both habitat types, plant community composition responded to the exclusion of red deer. Indications of beginning succession when fencing prevented red deer grazing were increasing height of sward and litter in both habitat types and, additionally, reduced cover of bare soil and increasing number of woody plant individuals in heathlands. In annually mown grasslands, where the regrowth provides attractive forage for red deer, the differences between open and fenced plots were most pronounced. Overall, our results indicate that the conservation value of the studied open habitat types started to decrease after red deer exclusion. Hence, we conclude that grazing by wild red deer provides benefits to vegetation structure and diversity and could therefore enrich the set of tools available for the conservation management of semi-natural open habitats.
\end{abstract}

\title{
Keywords
}

Cervus elaphus, grazing, mowing, Natura 2000, prescribed fire, species richness 


\section{Introduction}

Semi-natural open habitats are hotspots of plant and animal biodiversity at global as well as local scales, supporting many threatened species, and providing various ecosystem services (Harrison et al. 2010; Wrage et al. 2011; Carbutt et al. 2017).

Many open habitat types are associated with traditional extensive agricultural land use practices (Poschlod et al. 2009; Halada et al. 2011), which have shaped the European landscape in former times. Today, most of the agricultural land in Europe is intensively farmed, whereas marginal land is increasingly abandoned so that the maintenance of semi-natural open habitats is a continuous challenge to nature conservation (Poschlod et al. 2009; Hilpold et al. 2018). Alarmingly, only a small fraction of the open habitats protected under the EU Habitats Directive (e.g. 11.3\% of grasslands, $20.8 \%$ of heathlands) is in a favourable conservation status (European Environment Agency 2015).

Extensive grazing with different livestock species has become a valuable tool for conservation management in Europe (García et al., 2013; Rosenthal et al. 2012; Van Wieren, 1995). Grazing, trampling and defecation of large herbivores affect vegetation structure and composition (Milchunas et al. 1988; Cingolani et al. 2005) and can contribute to structural heterogeneity and biodiversity (Olff and Ritchie 1998; Adler et al. 2001). For very large or inaccessible areas, however, livestock grazing is inapplicable because regular monitoring of the animals and/or fencing is required. Under such circumstances, grazing by wild herbivores could be an alternative management option to keep up biomass removal levels as required for maintaining open habitats (Riesch et al. 2019).

Conservation science has only recently focused on the strong impact on vegetation development by wild herbivores, which actually represent key determinants of the ecology and evolution of vegetation worldwide (Sandom et al. 2014; Pausas and Bond 2018). From this perspective, more natural grazing regimes and ecological processes could potentially be restored by incorporating wild autochthonous herbivore species — such as red deer (Cervus elaphus) — into the conservation practice (Sutherland 2002; Ceaușu et al. 2015).

In contrast to the generally acknowledged conservation benefits of livestock grazing, grazing or browsing by free-ranging red deer has mostly been judged from an economic point of view (Putman and Moore 1998), as a cause of damage in forests and woodlands (Beguin et al. 2016; Eichhorn et al. 2017) or agriculture (Trdan and Vidrih 2007; Walter et al. 2011; Marchiori et al. 2012). Deer have also been criticised for deleterious effects on conservation habitats (Putman and Moore 1998), especially regarding their impact on heathlands (Albon et al. 2007; DeGabriel et al. 2011). However, a more differentiated perspective on red deer herbivory is increasingly supported (Virtanen et al. 2002; Mysterud 2006; Smolko et al. 2018). For example, grazing by wild red deer enhanced understory species richness in boreal old-growth forests (Hegland et al. 2013; Hegland and Rydgren 2016) and productive forests throughout France (Boulanger et al. 2018). Similarly, red deer have been driving changes in the vegetation of subalpine grasslands over several decades including a distinct increase in species richness with increasing deer density (Schütz et al. 2003). 
Consequently, red deer grazing could have potentially strong, positive impacts on herbaceous vegetation communities.

It is, however, yet unclear how red deer grazing affects the vegetation development in specific open habitats of high conservation importance, such as the habitat types listed in Annex I of the EU Habitats Directive. Red deer grazing ecology and vegetation impacts have been studied mostly on tamed or captive animals (Langvatn and Hanley 1993; Palmer and Hester 2000) or on wild, but not strictly free-ranging animals (Tschöpe et al. 2011; Fløjgaard et al. 2017). Thus, we lack a thorough understanding of the benefits or drawbacks of long-term grazing by wild and freeranging red deer for different open habitat types in Central Europe. Whether red deer grazing can preserve the characteristic species communities of specific habitat types in the long run can only be answered conclusively by long-term monitoring. The vegetation structure, however, responds more immediately to changes in grazing intensity (Dumont et al. 2011) and can therefore serve as an immediate indication whether the grazing intensity by red deer corresponds to habitat requirements. On the one hand, if grazing is not sufficient, the persistence of open habitats is critically endangered by natural succession involving the accumulation of litter, increasing vegetation height, density and biomass and the encroachment of woody species (Crofts and Jefferson 1999; Kahmen and Poschlod 2004). On the other hand, if the habitat use of red deer is too intensive, habitat quality could be compromised, for instance due to damage to the vegetation layer and increased cover of bare soil (Mysterud 2006).

As grazing requirements, or tolerance, differ between habitat types (Bakker et al. 2006; Moore et al. 2015), possibilities to spatially direct grazing activities by freeranging red deer would substantially advance the conservation management of open habitats in large-scale heterogeneous areas. The vegetation regrowth after biomass removal can be highly attractive to large herbivores (Langvatn and Hanley 1993; Wilmshurst et al. 1995; Allred et al. 2011; Proffitt et al. 2016). Removing vegetation biomass from selected areas by additional mechanical management, e.g. mowing or burning, could therefore be a potential strategy to influence the habitat use of red deer (Riesch et al. 2019). Hence, it is of interest to explore vegetation communities' responses to red deer grazing alone but also in combination with additional management treatments.

To assess the applicability of grazing by wild and free-ranging red deer for conservation purposes, we established a grazing exclusion experiment in two Natura 2000 habitat types, lowland hay meadows and European dry heaths, within an active military training area in Germany. Over three years, we monitored the development of different structural vegetation characteristics in pairs of open, continuously grazed plots and fenced plots protected against grazing. Besides, we compared the vegetation composition and diversity before and at the end of the period of red deer exclusion in the paired plots. In general, we hypothesised that the conservation value of habitats would diminish following red deer exclusion because of missing grazing benefits to vegetation structure and diversity. More specifically, we expected (i) changes in diversity and species composition introduced by red deer exclusion; (ii) the vegetation structure in fenced plots to show initial evidence of natural succession; 
(iii) most pronounced effects of red deer exclusion where additional management was applied making vegetation more attractive to red deer.

\section{Methods}

\section{Study area}

We studied vegetation responses to the exclusion of wild red deer in the US Army Garrison Grafenwöhr military training area (GTA) in Bavaria, Germany (49 40' 56" N, $11^{\circ} 47^{\prime} 20^{\prime \prime}$ E, Online Resource Fig. S1). GTA covers approximately $230 \mathrm{~km}^{2}$, composed of $60 \%$ forest and $40 \%$ open land (C. Raab, unpublished). Long-time (1981-2010) annual averages of temperature and precipitation are $8.3 \pm 0.04{ }^{\circ} \mathrm{C}$ and $701 \pm 4 \mathrm{~mm}$ (mean $\pm \mathrm{SE}$ of four weather stations of the German Weather Service (Deutscher Wetterdienst) in close proximity to GTA, Fig. S2). Designated as a Site of Community Importance and Special Area of Conservation (DE6336301), about 85\% of GTA belong to the European Natura 2000 network. Implementing livestock grazing is not possible in most parts of GTA because of the permanent intensive military training and the restricted public access. The abundance of wildlife species, especially red deer, is high (annual harvest numbers averaged over the study years: 1493 red deer, 584 roe deer (Capreolus capreolus), 553 wild boars (Sus scrofa)). The German Federal Forests Division (Bundesforst) is in charge of the land and hunting management in GTA. For several decades, the hunting management has been aiming at reducing damage to the forest by encouraging red deer to make use of the open landscapes. Therefore, hunting in open areas is largely limited to driven hunts on few days in early winter to minimise disturbances to the red deer's natural behaviour and circadian movement patterns (Meißner et al. 2013). By contrast, hunting in forested areas (driven and still hunts) continues during the entire hunting season defined by the federal state's hunting regulations (six to eight months). In consequence, red deer's habitat use of open land in GTA is intense and forage removal is considerable (Meißner et al. 2013, Riesch et al. 2019).

\section{Experimental design}

We set up a grazing exclusion experiment in the two open habitat types with the largest total area in GTA: lowland hay meadows (EU Habitats Directive Annex I habitat type 6510, hereafter 'grasslands') and European dry heaths (habitat type 4030, 'heathlands'), covering 340 and 463 ha, respectively (Fig. S1). The grasslands largely belong to the Arrhenatherion elatioris vegetation alliance and the heathlands belong to the Vacinio-Callunetum vulgaris association. The grasslands are situated in the western third of the GTA within a large (semi-)open area on calcareous soils, whereas the heathlands form small-sized patches within shrub- or forest-dominated areas in the eastern part of GTA on Triassic sandstone and highly acidic, sandy soils. Further, larger heathland areas exist within the shooting ranges and the main ordnance impact areas, where access is permanently prohibited. In both habitat types, the soil fertility is low as no agricultural inputs occurred over the more than one hundred years of military land use in GTA (average values for P (CAL), $\mathrm{K}(\mathrm{CAL})$ and $\mathrm{Mg}\left(\mathrm{CaCl}_{2}\right)$ in 
grasslands: $11.7 \mathrm{mg} \mathrm{kg}^{-1}, 52.1 \mathrm{mg} \mathrm{kg}^{-1}, 139.1 \mathrm{mg} \mathrm{kg}^{-1}$; in heathlands: $4.2 \mathrm{mg} \mathrm{kg}{ }^{-1}, 47.3$ $\mathrm{mg} \mathrm{kg}{ }^{-1}, 39.2 \mathrm{mg} \mathrm{kg}^{-1}$; Riesch et al. 2018).

In each habitat type, we established five sampling sites (Fig. S1). In grasslands, each sampling site (c. 1 ha) was composed of three equally sized treatments: burnt (B), mown (M) and untreated (U) grassland. These treatments started in 2015; prior to that, all grassland sites had been mown once per year over several decades. The B treatment was burnt at the end of March or at the beginning of April in 2015 to 2017. In accordance with the previous land management, the $M$ treatment was mown annually in July by a tractor mower and biomass was removed as haylage. In 2014, we designated two plots of $225 \mathrm{~m}^{2}(15 \times 15 \mathrm{~m})$ within each treatment. The plots were randomly assigned as 'open' or 'fenced', totalling 30 plots in grasslands. In heathlands, we could not implement the $\mathrm{M}$ and $\mathrm{B}$ treatments, as mowing was impossible due to abundant remnants of ammunition in that area of GTA, and burning failed due to unfavourable weather conditions and low standing biomass. Accordingly, in heathland sites (c. 0.5 ha), U was the single treatment, which was assessed on three sites with two pairs of plots and two sites with one pair of plots, resulting in 16 plots in heathlands.

The fences excluding all larger animals $(10 \times 30 \mathrm{~cm}$ mesh size, $2 \mathrm{~m}$ height $)$ were installed in July and September 2015 in grasslands and heathlands, respectively. After fencing, the size of the fenced plots was slightly smaller $(11 \times 11 \mathrm{~m})$ because the fences were constructed of prefabricated elements with defined size (Figs S7, 8). Both open and fenced plots received the $\mathrm{M}$ and $\mathrm{B}$ treatment in grasslands.

\section{Data collection}

In 2014, before the beginning of the experiment, the vegetation had been surveyed in one relevé $(5 \times 5 \mathrm{~m})$ per plot as part of a study on the relationships between soil chemical parameters and plant communities using a larger number of relevés (Riesch et al. 2018). Owing to logistical constraints, the relevés of one grassland site and one heathland site were surveyed one year later in 2015. The relative biomass contribution of each vascular plant species to the total aboveground plant dry matter biomass was visually estimated as described by Klapp (1965; see also Boob et al. 2019) in grassland and heathland relevés in summer and autumn, respectively. The nomenclature of plant species follows Jäger (2011). Species of the species-rich genera Alchemilla and Hieracium that could not be identified with certainty were recorded as Alchemilla sp. 1-3 and Hieracium sp. 1-2. The taxa Crataegus, Ononis and Prunus were recorded at the genus level. To assess changes in vegetation composition and diversity introduced by the experimental treatments and red deer grazing exclusion, all relevés were resurveyed in 2018 according to the same procedure by the same botanist.

From 2015 to 2017, we recorded data on the vegetation height on five dates per year (April, May, June, August and October). In both habitat types and on each sampling date, we measured the compressed sward height (CSH) on 30 randomly chosen locations per plot with a rising-plate meter, which is an established method for assessing vegetation structure dynamics in heterogeneous swards (Correll et al. 2003). In heathlands, the percent area covered by bare soil and the percent biomass 
contribution of Calluna vulgaris to the total aboveground biomass were recorded as additional structural relevé characteristics.

Additionally, in April 2018, we measured the height of the litter layer as the distance between the soil and highest piece of fallen litter 30 times per plot with a pencilshaped ruler $(1 \mathrm{~cm}$ diameter) and counted the number of individuals of woody plant species per plot.

To substantiate our assumption that red deer is the main large herbivore foraging in open habitats in GTA, we used time-lapse cameras (PlotWatcher Pro, Day 6 Outdoors, Columbus, GA, US). In May 2016, we installed one camera on a $2.5 \mathrm{~m}$ wooden post at $5 \mathrm{~m}$ distance to the southern corner of each open plot, overviewing the complete plot area. The cameras took one picture per minute between sunrise and sunset over a 13-months period. As cameras occasionally failed, we had to exclude $41 \pm 11$ days (mean $\pm \mathrm{SE}$ ) from the reference period. On each picture, we counted the individuals of red deer, roe deer and wild boars within the plot area and calculated the frequency of occurrence for each species in minutes per day based on the number of days when the camera was working.

All data are supplied as supplementary files.

\section{Statistical analyses}

We conducted all data processing and statistics in $\mathrm{R}$ version 3.5.1 (R Core Team 2015). To assess the effects of red deer exclusion and additional management treatments in grasslands on the different components of vegetation diversity and structure, we performed univariate and multivariate analyses separately for grasslands and heathlands.

Species richness (SR) was calculated as the number of vascular plant species per relevé. As a measure for the heterogeneity of species abundances within communities, we calculated the Inverse Simpson index (Simpson 1949; Hill 1973) as $1 / \Sigma p_{i}^{2}$, with $p_{i}=$ the proportion of species $i$ in the community. This index represents the reciprocal of the probability that two individuals in a community belong to the same species and, hence, largely depends on the abundance of dominant species (Magurran 2004). We conducted univariate analyses of SR and diversity indices using linear mixed effects models (LME) in the package nlme (Pinheiro et al. 2015). Year (2014/2018), treatment (B/M/U, only in grasslands) and plot (open/fenced) and all their interactions served as explanatory variables. We accounted for the spatial nestedness of the experimental design using a nested random intercept composed of plot, treatment (grasslands) or pair (heathlands) and sampling site. We applied appropriate variance structure functions if needed to improve the normality and homogeneity of residuals. Starting from the full model, each model was simplified based on the second-order Akaike information criterion accounting for small sample size (AICc) to find the most parsimonious model. For this model, we computed the conditional $\left(R_{(c)}{ }^{2}\right)$ and the marginal coefficient of determination $\left(R_{(m)}{ }^{2}\right)$ expressing the variance explained by fixed and random effects combined and the variance explained by fixed effects alone (Nakagawa et al. 2017). To evaluate differences between open and fenced plots, we computed estimated marginal means and $p$-values for the 
pairwise comparisons between open and fenced plots using the package emmeans (Lenth 2018) for all cases where the explanatory variable plot was included in a significant model term in the most parsimonious model (Online Resource Table S2). For testing whether the exclusion of red deer translated into changes in vegetation community composition, we employed the R package muabund (Wang et al. 2012, 2018), providing tools for model-based analyses of multivariate abundance data. Using the function many.glm, which fits generalized linear models simultaneously to each species of a community, we assessed the effects of year (2014/2018), treatment (B/M/U, only in grasslands), plot (open/fenced) and their interactions on the community composition of grasslands and heathlands. In consideration of the meanvariance relationship, we specified a negative binomial distribution of the data with log-link function. As the negative binomial distribution cannot handle decimals, the community data were rounded to integers $(1-100)$ prior to analysis. To account for correlations between species, we calculated the Score test statistics using ridge regularization (Warton 2008) of the sample correlation matrix of the null model. The significance of the Score test statistic was determined by resampling rows of the data via bootstrapping probability integral transform residuals (PIT-trap, Warton et al. (2017); $n=999)$. To account for the spatially nested experimental design, we constrained resampling to sampling sites in grasslands $(n=5)$ and to a balanced factor composed of sampling site and plot pair in heathlands $(n=8)$.

To visualise patterns in the vegetation composition of grasslands and heathlands, we used two-dimensional non-metric multidimensional scaling (NMDS; Minchin (1987)) implemented in the $\mathrm{R}$ package vegan (Oksanen et al. 2015). The grassland and heathland plant community data were subjected to square root transformation and Wisconsin double standardisation. Dissimilarity matrices were computed using the Bray-Curtis index. To enhance interpretability and facilitate comparisons between grasslands and heathlands, the first NMDS axis was aligned with the SR gradient in both habitat types.

The structural response variables $\mathrm{CSH}$, litter height, number of woody individuals, bare soil cover (in heathlands only) and Calluna biomass contribution (in heathlands only) were analysed using LME models, in the same way as SR and the diversity indices. The explanatory variables in the full models for CSH (mean over the 30 measurements per plot), bare soil cover and Calluna biomass contribution were year (2015/2016/2017), month (April/May/June/August/October), treatment (B/M/U, only in grasslands), plot (open/fenced) and all interactions of these factorial variables. The models for litter height (mean over the 30 measurements per plot) and the number of woody individuals (log-transformed), assessed only in 2018, did not include the factor year nor month as explanatory variable and therefore omitted plot as random effect.

In figures and text, we present means $( \pm \mathrm{SE})$ of the raw data. Unless stated otherwise, we report results at the 0.05 significance level. 


\section{Results}

The camera survey substantiated that red deer were the main large wildlife species on our experimental plots in grasslands and heathlands (Table 1). Red deer occurred with a 300 times higher frequency on average than roe deer and with a 30 times higher frequency than wild boars. The amount of time red deer spent on the plots was lowest in the $\mathrm{U}$, intermediate in the $\mathrm{B}$ and highest in the $\mathrm{M}$ treatment. The frequency of red deer occurrence was similar in untreated grasslands and heathlands.

\section{Plant diversity and community composition}

The plant species richness in grasslands was affected by significant two-way interactions between plot and year as well as year and treatment (Fig. 1a, Table 2). In 2014, before the treatments and red deer exclusion were initiated, grasslands plant species richness was similar in all plots averaging 47 species per $25 \mathrm{~m}^{2}$ (Fig. 1a, Tables 2, S2). In 2018, species richness was significantly reduced compared to the initial survey to an average of 40 species per relevé. While the open plots harboured an average of 42 species in 2018, only 37 species occurred on average in the fenced plots, though the significance level for this pairwise comparison was slightly exceeded ( $p=0.058$, Table S2). Besides, in 2018, the average species richness was significantly lower in the $\mathrm{U}$ treatment (34 species) than in the $\mathrm{M}$ treatment (45 species) and intermediate in the B treatment (40 species).

Like species richness, the Inverse Simpson index did not differ significantly between treatments or open and fenced plots in 2014 with an overall average of 10.4 (Fig. 1b, Tables 2, S2). In 2018, the Inverse Simpson index in the fenced plots was significantly reduced, averaging 6.5 across all treatments. In the $\mathrm{M}$ treatment, the Inverse Simpson index was significantly higher in the open (12.2) than in the fenced plots (7.5) irrespective of study year. The opposite pattern was true for the BergerParker index (Fig. S3, Tables S1, S2).

In heathlands, an average of 14 plant species per relevé was recorded in 2014. In 2018, plant species richness was significantly lower and only 11 species occurred on average per relevé (Fig. S4, Table 2). The Inverse Simpson and Berger-Parker index averaged 1.6 and 0.80 , respectively. Neither plant species richness nor diversity indices (for which the respective most parsimonious model included the intercept only) responded to the experimental exclusion of red deer in heathlands.

Table 1: Frequency of occurrence (mean $\pm \mathrm{SE}$, min $\mathrm{d}^{-1}$ ) of large wildlife species in daylight on the open experimental plots $\left(225 \mathrm{~m}^{2}\right)$ in burnt $(\mathrm{B})$, mown $(\mathrm{M})$ and untreated $(\mathrm{U})$ grasslands $(n=5)$ and untreated heathlands $(n=8)$ in Grafenwöhr military training area averaged over a 13-month period (May 2016 to May 2017).

\begin{tabular}{llrrrrr}
\hline $\begin{array}{l}\text { Habitat } \\
\text { type }\end{array}$ & Treatment & \multicolumn{2}{c}{ Red deer } & \multicolumn{2}{c}{ Roe deer } & \multicolumn{2}{c}{ Wild boars } \\
\hline Grasslands & $\mathrm{B}$ & $3.647 \pm 1.401$ & $0.006 \pm 0.005$ & $0.423 \pm 0.346$ \\
& $\mathrm{M}$ & $4.440 \pm 1.349$ & $0 \pm 0$ & $0.032 \pm 0.026$ \\
& $\mathrm{U}$ & $2.824 \pm 1.487$ & $0.001 \pm 0.001$ & $0.032 \pm 0.009$ \\
Heathlands & $\mathrm{U}$ & $2.939 \pm 1.615$ & $0.038 \pm 0.009$ & $0.005 \pm 0.002$ \\
\hline
\end{tabular}


(a)
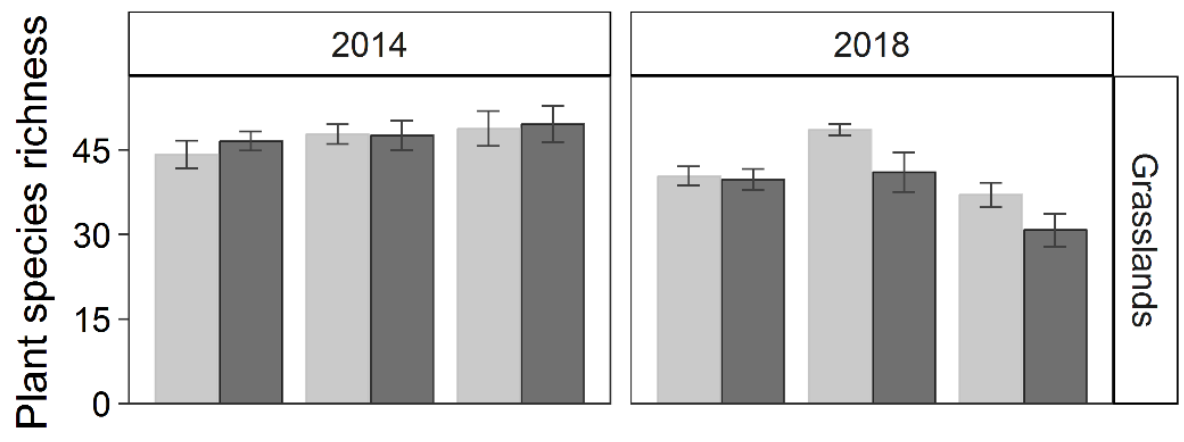

(b)

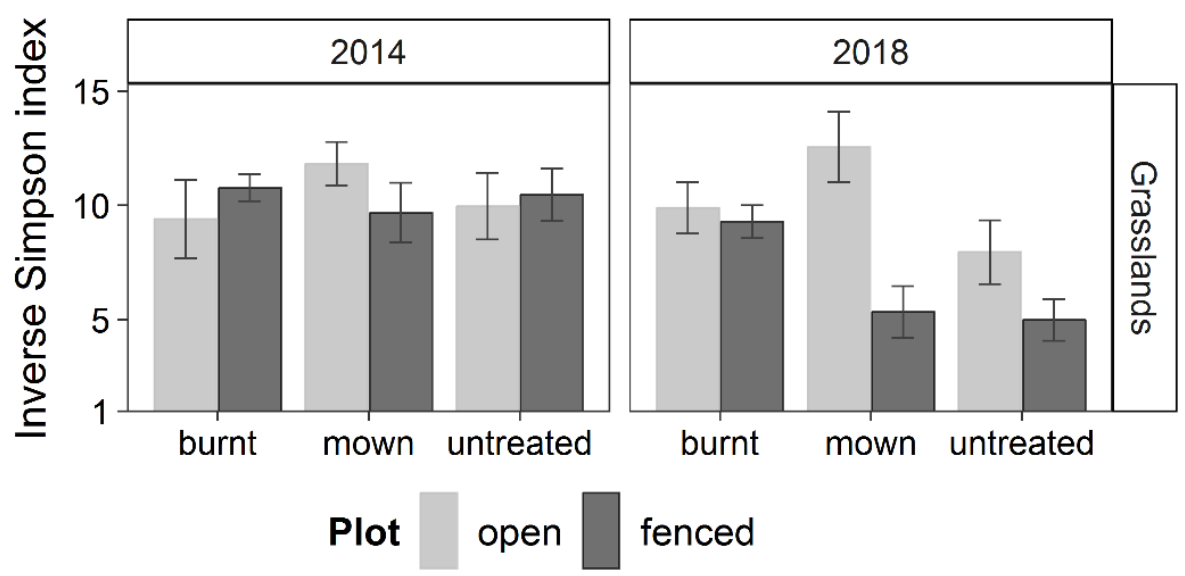

Figure 1: Mean and standard error of plant species richness and Inverse Simpson index of plant communities in relevés $\left(25 \mathrm{~m}^{2}\right)$ within plots open to or protected against red deer grazing (fenced) in burnt, mown and untreated grasslands $(n=5)$ in Grafenwöhr military training area in 2014 before the beginning of the experiment and 2018 after more than 30 months of red deer exclusion from the fenced plots.

The NMDS ordinations of grassland and heathland plant communities (Fig. 2a,c) suggested that plant community composition was similar for all combinations of treatment and plots in 2014, while the communities of open and fenced plots differentiated from each other in 2018 (Fig. 2b,d). Additionally, the grassland ordination indicated emerging differences between the communities of the $\mathrm{B}, \mathrm{M}$ and $\mathrm{U}$ treatment (Fig. 2b). The model-based multivariate analysis corroborated the patterns apparent from the ordinations (Table 3). The interaction effect of year and plot was significant in both grasslands and heathlands. Though not significant, interaction effects of treatment with year or with year and plot in grasslands were associated with low $p$-values $(p<0.1)$.

\section{Vegetation structure}

In both grasslands and heathlands, marked differences in the CSH between open and fenced plots developed over the course of the experiment from April 2015 to October 2017 (Figs 3, S7, S8, Tables 2, S2). After the exclusion fences had been installed in grasslands in July 2015, the CSH was significantly higher by $1.3 \mathrm{~cm}$ in the fenced plots than in the open plots across all treatments already in October 2015. The difference in CSH between open and fenced plots gradually became more pronounced and finally, in October 2017, the grassland vegetation in fenced plots 
Table 2: Results of univariate analyses of the effect of red deer exclusion on vegetation structure and diversity. Numerator $\left(d f_{(\text {num })}\right)$ and denominator degrees of freedom $\left(d f_{(\mathrm{den})}\right), F$ and $p$-values for sequential Wald tests for the factors retained in the most parsimonious linear mixed effects models for plant diversity and vegetation structure response variables in grasslands and heathlands including each model's marginal $\mathrm{R}_{(m)}{ }^{2}$ and conditional coefficient of determination $R_{(c)^{2}}$ according to Nakagawa et al. (2017). Results of the models for diversity indices in heathlands are not shown because the most parsimonious model in these cases contained the intercept only.

\begin{tabular}{|c|c|c|c|c|c|c|c|c|}
\hline Response & $\begin{array}{l}\text { Habitat } \\
\text { type }\end{array}$ & Factor & $d f_{\text {(num) }}$ & $d f_{(\mathrm{den})}$ & F & $p$-value ${ }^{e}$ & $\mathrm{R}_{(m)^{2}}$ & $\mathrm{R}_{(c)^{2}}$ \\
\hline Species & Grasslands & Plot $^{a}$ & 1 & 14 & 0.50 & 0.493 & 0.44 & 0.64 \\
\hline \multirow[t]{5}{*}{ richness } & & Year $^{b}$ & 1 & 26 & 60.03 & $\leq 0.001$ & & \\
\hline & & Treatment $^{c}$ & 2 & 8 & 1.86 & 0.218 & & \\
\hline & & Plot $\times$ Year & 1 & 26 & 6.58 & 0.016 & & \\
\hline & & Year $\times$ Treatment & 2 & 26 & 9.25 & 0.001 & & \\
\hline & Heathlands & Year & 1 & 15 & 6.20 & 0.025 & 0.05 & 0.99 \\
\hline Inverse & Grasslands & Plot & 1 & 12 & 6.98 & 0.022 & 0.37 & 0.38 \\
\hline Simpson & & Year & 1 & 28 & 8.37 & 0.007 & & \\
\hline \multirow[t]{3}{*}{ index } & & Treatment & 2 & 8 & 2.04 & 0.192 & & \\
\hline & & Plot $\times$ Year & 1 & 28 & 6.31 & 0.018 & & \\
\hline & & Plot $\times$ Treatment & 2 & 12 & 4.58 & 0.033 & & \\
\hline \multirow{17}{*}{$\begin{array}{l}\text { Compressed } \\
\text { sward height } \\
(\mathrm{cm})\end{array}$} & Grasslands & Plot & 1 & 12 & 29.15 & $\leq 0.001$ & 0.94 & 0.96 \\
\hline & & Year & 2 & 376 & 10.56 & $\leq 0.001$ & & \\
\hline & & Treatment & 2 & 8 & 50.70 & $\leq 0.001$ & & \\
\hline & & Month $^{d}$ & 4 & 376 & 814.60 & $\leq 0.001$ & & \\
\hline & & Plot $\times$ Year & 2 & 376 & 48.85 & $\leq 0.001$ & & \\
\hline & & Plot $\times$ Treatment & 2 & 12 & 2.16 & 0.158 & & \\
\hline & & Plot $\times$ Month & 4 & 376 & 11.71 & $\leq 0.001$ & & \\
\hline & & Year $\times$ Treatment & 4 & 376 & 10.78 & $\leq 0.001$ & & \\
\hline & & Year $\times$ Month & 8 & 376 & 42.01 & $\leq 0.001$ & & \\
\hline & & Treatment $\times$ Month & 8 & 376 & 81.85 & $\leq 0.001$ & & \\
\hline & & Plot $\times$ Year $\times$ Treatment & 4 & 376 & 4.09 & 0.003 & & \\
\hline & & Plot $\times$ Year $\times$ Month & 8 & 376 & 5.19 & $\leq 0.001$ & & \\
\hline & Heathlands & Plot & 1 & 7 & 1.21 & 0.307 & 0.64 & 1.00 \\
\hline & & Year & 2 & 208 & 54.35 & $\leq 0.001$ & & \\
\hline & & Month & 4 & 208 & 82.89 & $\leq 0.001$ & & \\
\hline & & Plot $\times$ Year & 2 & 208 & 67.17 & $\leq 0.001$ & & \\
\hline & & Year $\times$ Month & 8 & 208 & 4.28 & $\leq 0.001$ & & \\
\hline \multirow{5}{*}{$\begin{array}{l}\text { Bare soil } \\
\text { cover }(\%)\end{array}$} & Heathlands & Plot & 1 & 7 & 4.83 & 0.064 & 0.10 & 0.45 \\
\hline & & Year & 2 & 208 & 11.80 & $\leq 0.001$ & & \\
\hline & & Month & 4 & 208 & 4.32 & 0.002 & & \\
\hline & & Plot $\times$ Year & 2 & 208 & 13.62 & $\leq 0.001$ & & \\
\hline & & Year $\times$ Month & 8 & 208 & 4.38 & $\leq 0.001$ & & \\
\hline \multirow{4}{*}{$\begin{array}{l}\text { Litter height } \\
\text { (cm) }\end{array}$} & Grasslands & Treatment & 2 & 8 & 72.41 & $\leq 0.001$ & 0.90 & 0.94 \\
\hline & & Plot & 1 & 12 & 74.45 & $\leq 0.001$ & & \\
\hline & & Treatment $\times$ Plot & 2 & 12 & 19.69 & $\leq 0.001$ & & \\
\hline & Heathlands & Plot & 1 & 7 & 15.70 & 0.005 & 0.45 & 0.57 \\
\hline \multirow{2}{*}{$\begin{array}{l}\text { Woody } \\
\text { individuals }\end{array}$} & Grasslands & Treatment & 2 & 8 & 4.44 & 0.050 & 0.39 & 0.89 \\
\hline & Heathlands & Plot & 1 & 7 & 10.27 & 0.015 & 0.33 & 0.51 \\
\hline
\end{tabular}

aType of plot; factor (open/fenced)

bStudy year; factor $(2015,2016,2017$ or 2014/2018)

'Treatments in grasslands; factor (burnt/mown/untreated)

dMonth of sampling; factor (April/May/June/August/October)

eBold type face indicates statistical significance $(p<0.05)$ 
(a)

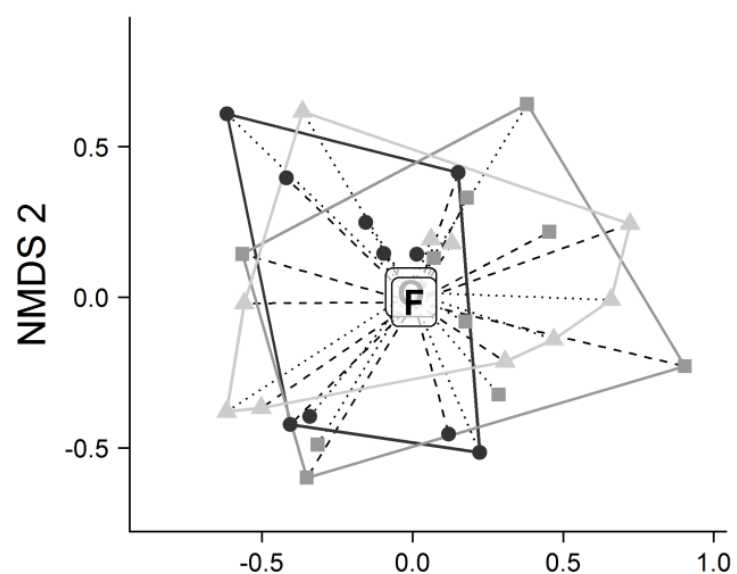

(c)

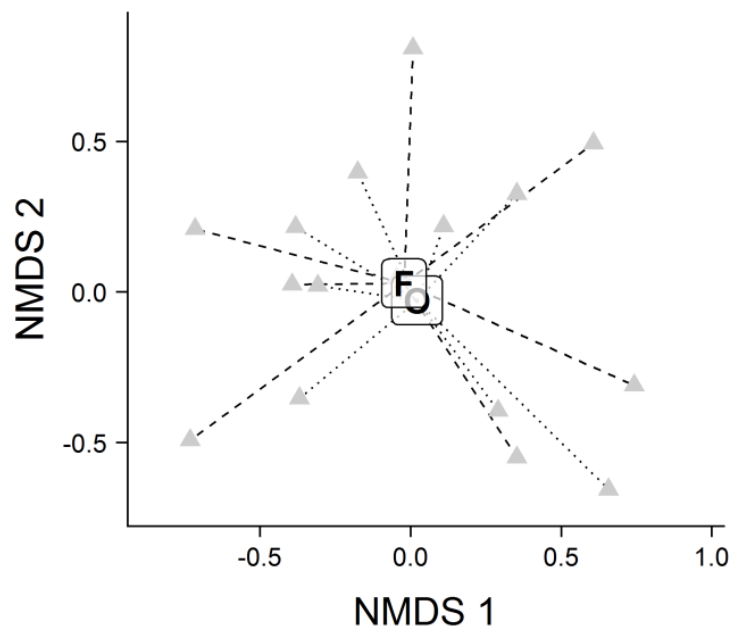

(b)

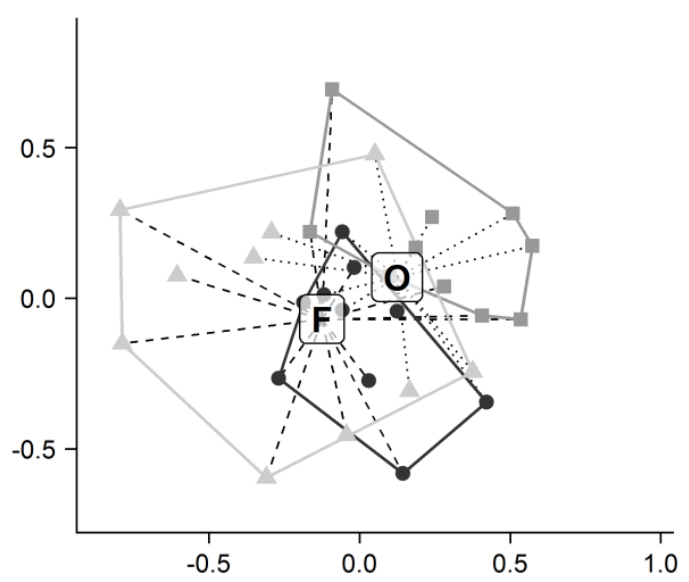

(d)

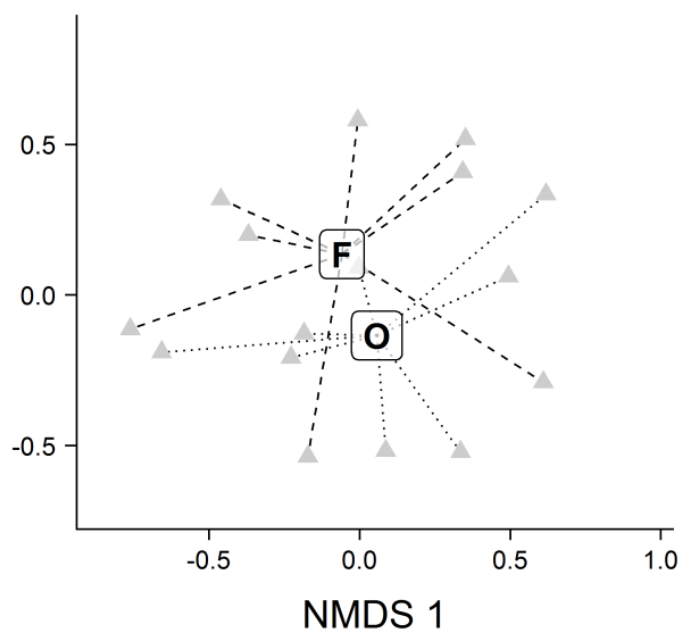

Plot $\cdots$ O, open -- F, fenced

Figure 2: Two-dimensional NMDS ordinations of plant species communities open to or protected against red deer grazing (fenced) in burnt, mown and untreated grasslands (a, b) and untreated heathlands (c, d) in Grafenwöhr military training area in 2014 before the beginning of the experiment and 2018 after more than 30 months of red deer exclusion. NMDS stress: grasslands 0.19 (2014) and 0.21 (2018), heathlands 0.11 (2014) and 0.17 (2018).

was on average $5.0 \mathrm{~cm}$ higher than in the open plots. This effect of red deer exclusion was similar in all grassland treatments. In heathlands, where the exclusion fences had been installed in September 2015, the CSH in the fenced plots started to increase significantly relative to the open plots in the second study year. While in 2016 the heathland vegetation was on average $1.6 \mathrm{~cm}$ higher in the fenced plots than in the open plots, the difference in CSH increased to an average of $3.5 \mathrm{~cm}$ throughout 2017. 
Table 3: Results of multivariate analyses of the effect of red deer exclusion on vegetation community composition. Degrees of freedom, sequential Score test statistic and $p$-value of multivariate generalized linear models of species composition in grasslands and heathlands.

\begin{tabular}{|c|c|c|c|c|c|}
\hline Habitat type & Parameter & Residual df & $d f$ & Score & $p$-value ${ }^{\mathrm{d}}$ \\
\hline \multicolumn{6}{|l|}{ Grasslands } \\
\hline & (Intercept) & 59 & & & \\
\hline & Year $^{a}$ & 58 & 1 & 69.28 & 0.981 \\
\hline & Treatment $^{\mathrm{b}}$ & 56 & 2 & 88.99 & 0.063 \\
\hline & $\operatorname{Plot}^{c}$ & 55 & 1 & 35.99 & 0.433 \\
\hline & Year $\times$ Treatment & 53 & 2 & 96.04 & 0.098 \\
\hline & Year $\times$ Plot & 52 & 1 & 50.64 & 0.032 \\
\hline & Treatment $\times$ Plot & 50 & 2 & 77.91 & 0.224 \\
\hline & Year $\times$ Treatment $\times$ Plot & 48 & 2 & 71.60 & 0.098 \\
\hline \multicolumn{6}{|l|}{ Heathlands } \\
\hline & (Intercept) & 31 & & & \\
\hline & Year & 30 & 1 & 22.48 & 0.673 \\
\hline & Plot & 29 & 1 & 10.24 & 0.399 \\
\hline & Year $\times$ Plot & 28 & 1 & 20.43 & 0.047 \\
\hline
\end{tabular}

aStudy year; factor (2014/2018)

${ }^{\mathrm{b}}$ Treatments in grasslands; factor (burnt/mown/untreated)

cType of plot; factor (open/fenced)

dBold type face indicates statistical significance $(\mathrm{p}<0.05)$

In heathlands, from 2016 on, the cover of bare soil also started to differentiate between open and fenced plots, in which the area covered by bare soil continuously decreased (Fig. 4, Tables 2, S2). The difference in bare soil cover became significant in 2017 when on average $9.8 \%$ of the area of open plots was covered by bare soil compared to $4.4 \%$ the fenced plots. This equals approximately a $50 \%$ reduction in the fenced plots relative to the initial average bare soil cover in 2015. The increasing estimated contribution of C. vulgaris to the total aboveground biomass (Fig. S5, Tables S1, S2) mirrored the decreased area of bare soil in the fenced plots.

The height of the litter layer measured in April 2018, 32 and 30 months after the exclusion fenced had been installed in grasslands and heathlands, respectively, revealed further significant differences between open and fenced plots (Fig. 5, Tables 2, S2). In grasslands, the litter layer was on average 3.2 and $3.3 \mathrm{~cm}$ thicker in the fenced than in the open plots in the $\mathrm{M}$ and $\mathrm{U}$ treatment, corresponding to a relative increase in litter height of 149 and $62 \%$, respectively. In the B treatment, the litter layer was considerably thinner than in the other treatments and did not differ between open and fenced plots. In heathlands, the litter layer in the fenced plots was on average $1.6 \mathrm{~cm}(73 \%)$ higher than in the open plots. 


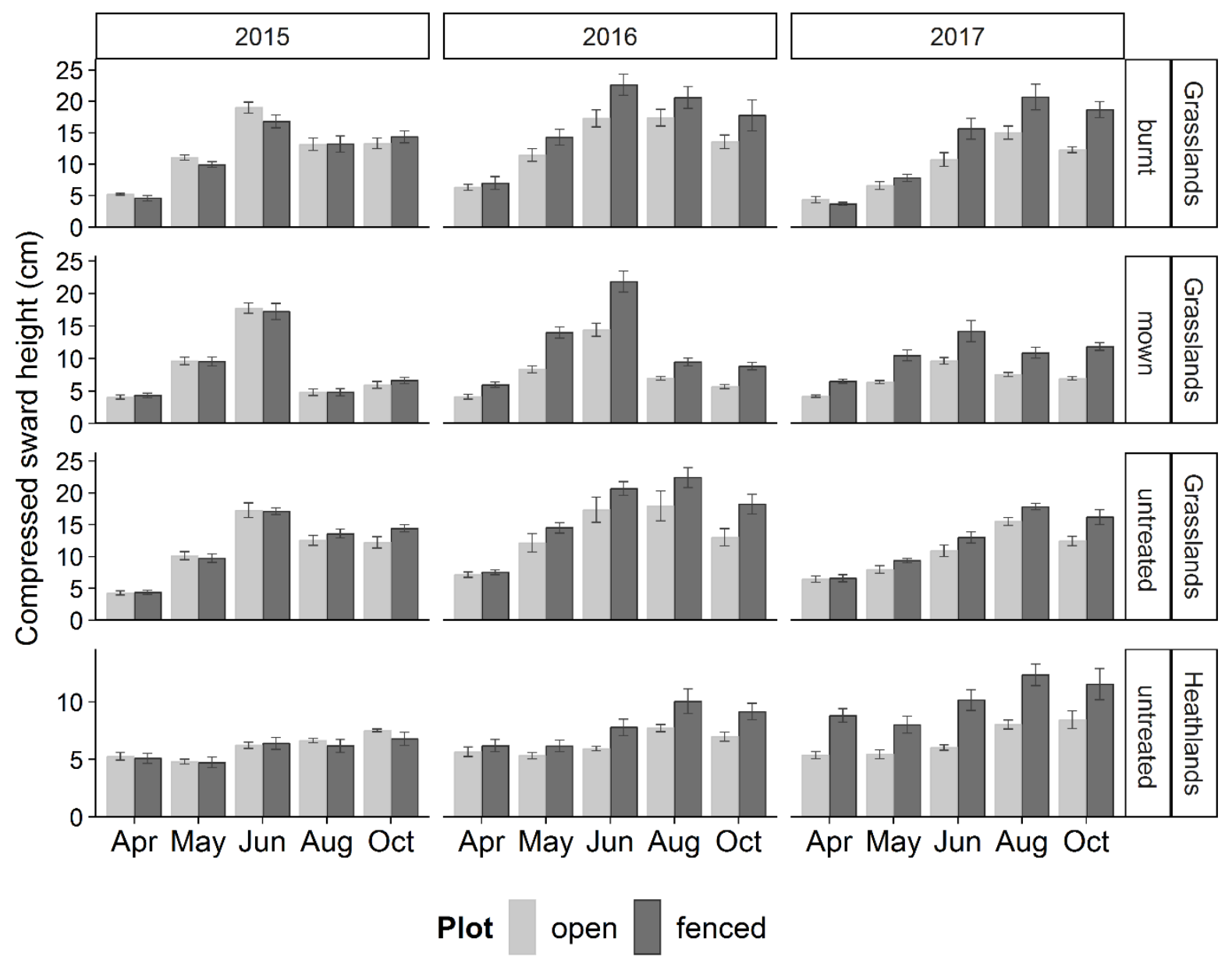

Figure 3: Mean and standard error of compressed sward height $(\mathrm{cm})$ in sampling plots open to or protected against red deer grazing (fenced) in burnt, mown and untreated grasslands ( $n$ $=5$ ) and untreated heathlands $(n=8)$ in Grafenwöhr military training area measured 30 times per plot at five dates per vegetation period in 2015-2017.
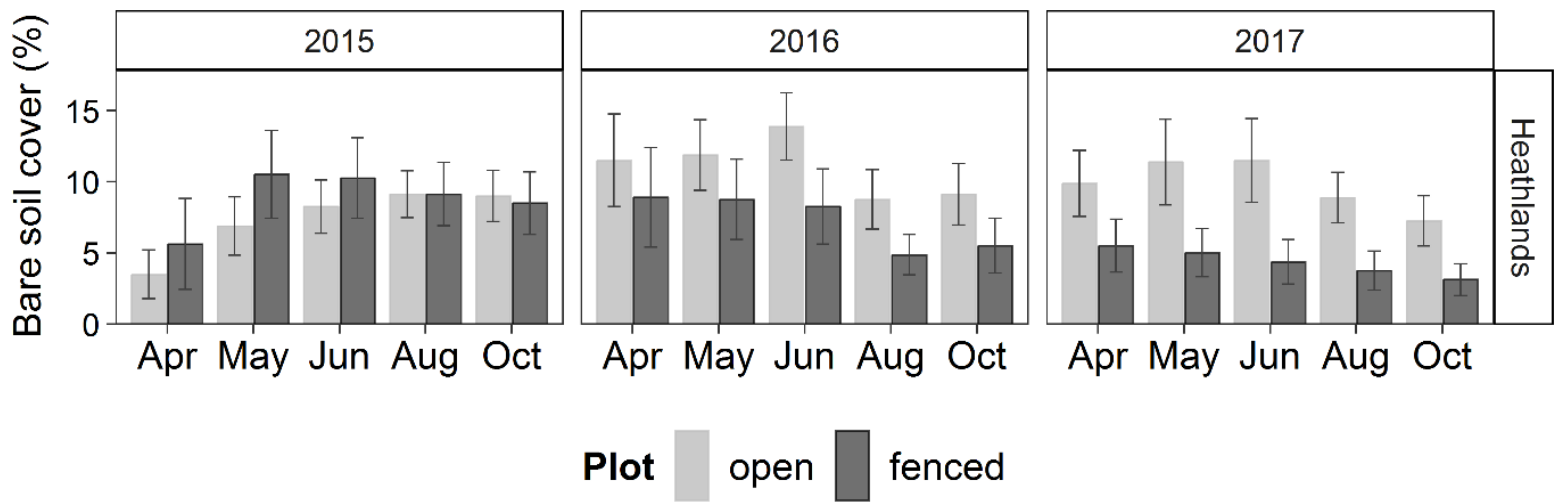

Figure 4: Percent cover of bare soil (mean \pm SE) in sampling plots open to or protected against red deer grazing (fenced) in heathlands $(n=8)$ in Grafenwöhr military training area estimated at five dates per vegetation period in 2015-2017. 


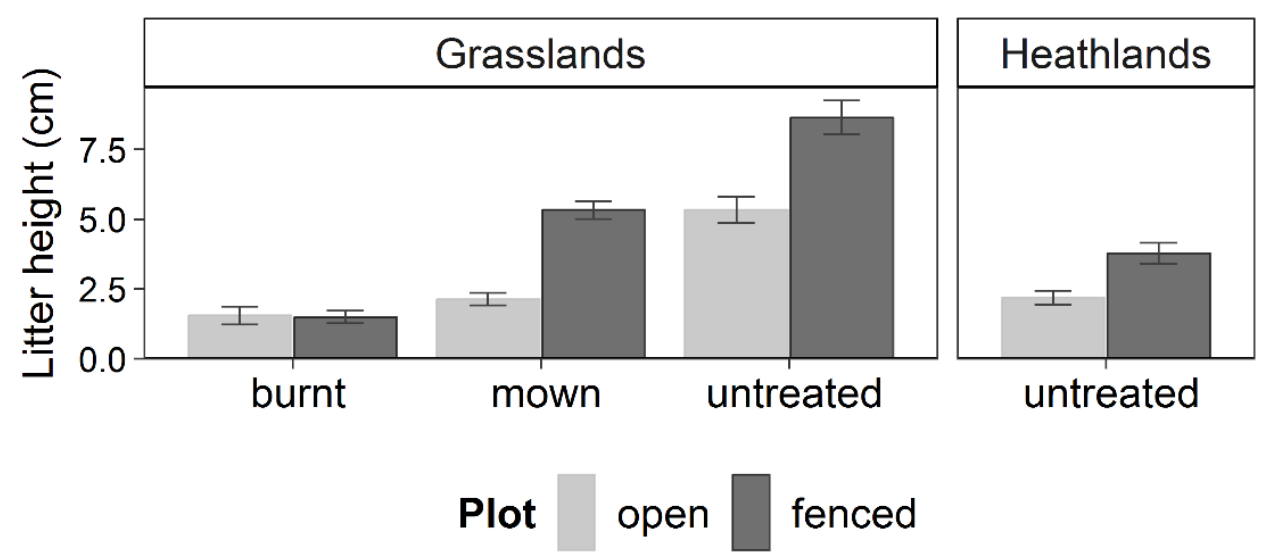

Figure 5: Mean and standard error of litter height $(\mathrm{cm})$ in sampling plots open to or protected against red deer grazing (fenced) in burnt, mown and untreated grasslands $(n=5)$ and untreated heathlands $(n=8)$ in Grafenwöhr military training area in April 2018 after more than 30 months of red deer exclusion.

The number of woody plant individuals counted at the end of the experiment in 2018 did not differ significantly between open and fenced plots in grasslands (Fig. 6, Table 2). There were, however, pronounced differences between grassland treatments. While woody plants were almost absent from the $\mathrm{M}$ treatment and the number of individuals was very variable in the B treatment, a significantly higher number of woody plants occurred in the $U$ treatment (4 individuals on average per plot). In heathlands, the exclusion of red deer from the fenced plots resulted in a multiple times higher number of woody plant individuals relative to the open plots (Fig. 6, Tables 2, S2). The difference amounted to a surplus of more than 305 woody plant individuals in the fenced plots, equivalent to a $266 \%$ increase in comparison to the open plots.

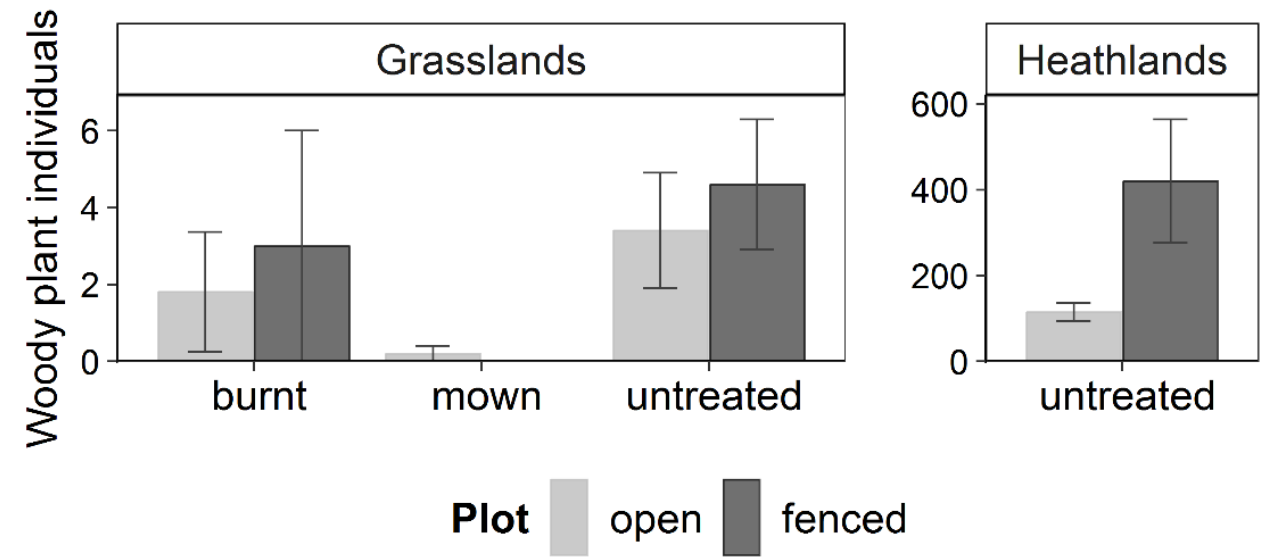

Figure 6: Number of woody plant individuals (mean \pm SE) in sampling plots open to or protected against red deer grazing (fenced) in burnt, mown and untreated grasslands $(n=5)$ and untreated heathlands $(n=8)$ in Grafenwöhr military training area counted in April 2018 after more than 30 months of red deer exclusion. 


\section{Discussion}

The experimental exclusion of wild and free-ranging red deer from two different open habitat types of high conservation interest over almost three years revealed distinct effects of wildlife grazing on vegetation diversity, composition and structure. Our results indicate that the conservation value of the semi-natural habitats started to decrease after red deer exclusion as grazing benefits to vegetation structure and diversity ceased.

\section{Red deer exclusion effects in grasslands}

After 32 months of red deer exclusion, the difference in species richness between open and fenced plots in 2018 just failed to meet the threshold for statistical significance of $p<0.05$ (Fig. 1a, Table S2). From livestock grazing systems, there is evidence that changes in plant species richness relating to management may take a long time to manifest, e.g. more than six years (Dumont et al. 2011), which is twice as long as the study period encompassed by our experiment. Based on diversity indices, however, we showed that red deer could indeed play an important role for maintaining grassland plant diversity. Diversity indices are often superior to species richness in reflecting the response of plant species communities to changes in management because they account for the species' abundances, which change more immediately than the species richness of the whole community (Wilsey et al. 2005). The Inverse Simpson index was significantly enhanced in open relative to fenced plots, which suggests that the exclusion of red deer promoted species contributing a high share to the total vegetation biomass. The Berger-Parker index corroborated this interpretation, confirming that the proportion of the most dominant species in a relevé was significantly lower in open than in fenced plots. This implies that red deer grazing can alter the competitive environment in the plant community by effectively reducing the abundance of dominant species, which has recently been proposed as a key mechanism how grazing can enhance plant biodiversity independently from site productivity (Koerner et al. 2018). In principle, our results based on the short-term experimental exclusion of red deer grazing in grasslands are in line with findings

from a long-term observational study in the Swiss National Park, where the average number of plant species in preferred red deer grazing areas had doubled over a 82year period (Schütz et al. 2003).

The model-based multivariate analysis confirmed a significant change in grassland plant community composition introduced by the experimental red deer exclusion (Table 3). The NMDS ordination illustrated trends in community change corresponding to the results of the univariate analyses (Figs 2a,b and S6a). The arrangement of species in the ordination mirrored the differentiation between fenced and open plots along the first NMDS axis (i.e. the species richness gradient), with species indicative of abandonment (e.g. Crataegus spp., Centaurea scabiosa) grouping to the left and short-grass vegetation species typical of pastures (e.g. Lolium perenne, Cynosurus cristatus) occupying the right part of the ordination space.

A first sign of beginning succession in the fenced grassland plots was the increasing vegetation height, which became significantly higher relative to the open plots already 
after two months of red deer exclusion. Furthermore, in the last study year, a significantly higher litter layer had accumulated in the fenced than in the open plots of the $\mathrm{M}$ and $\mathrm{U}$ treatment (Fig. S7). As litter can impair germination and establishment of plant species in grasslands (Ruprecht et al. 2010; Kelemen et al. 2013), the litter accumulation following grazing exclusion could have contributed to diminishing plant diversity in the fenced plots.

\section{Interactions of red deer grazing with additional grassland management}

The effects of red deer grazing exclusion on grassland plant diversity, sward height and litter height were moderated by the additional grassland management treatments. We had expected to observe increased differences between open and fenced plots when mechanical management was applied in addition to red deer grazing. This assumption builds on earlier studies showing that the removal of vegetation biomass by mowing or burning is followed by regrowth with high nutritional quality, which, in turn, attracts red deer and increases grazing intensity (Langvatn and Hanley 1993; Wilmshurst et al. 1995; Proffitt et al. 2016). Alternatively, one could assume that the removal of a large proportion of the aboveground biomass at a time by mowing or burning might override or blur the effects of grazing, which successively removes only small proportions of plant biomass. In our experiment, the plant diversity in the fenced plots was significantly reduced compared to the open plots in the $\mathrm{M}$ but not in the B and U treatment. Similarly, the sward height differed most distinctly between open and fenced plots in the M treatment (Table S2). These results suggest that the cessation of red deer grazing affected the vegetation of mown grasslands most strongly. In line with our hypothesis, this could be explained by the elevated productivity and forage quality in the mown grasslands (Riesch et al. 2019), providing an attractive resource for red deer. From our camera survey, we can infer that red deer actually grazed mown grasslands more intensively, since the highest frequency of red deer occurrence was recorded on the plots of the M treatment (Table 1). As our cameras took pictures every minute in daylight but not at dark, it should be noted that these data are well-suited for comparing the red deer frequency of occurrence between treatments but do not represent the actual time red deer spent on a plot within 24 hours. The overall daily presence of red deer per plot might have been multiple times higher as GPS data of red deer living in the surroundings of the grassland sampling in GTA indicate a much higher use of open habitats at dark than in daylight (unpublished data).

In the $\mathrm{B}$ treatment, where the frequency of red deer occurrence was intermediate, the effects of red deer exclusion on the vegetation were less conclusive than in the $M$ treatment, although interactions between red deer habitat use and fire are well-known (Proffitt et al. 2016; Sittler et al. 2019). This may partly be explained by the fact that in the first two study years burning succeeded only on three out of the five grassland study sites (Riesch et al. 2019).

\section{Red deer exclusion effects in heathlands}

In heathlands, the experimental exclusion of red deer did not trigger a response of species richness or diversity indices after 30 months, although our camera survey 
showed that the range of red deer frequency of occurrence in heathlands was largely comparable to that in grasslands. Plant species richness was lower in both open and fenced heathland plots in the resurvey in 2018, which was probably related to the exceptionally dry weather conditions during that year (Fig. S2). Nonetheless, our model-based multivariate analysis revealed that the heathland plant community composition significantly diverged in response to the exclusion of red deer (Table 3 , Fig. 2c,d). Accordingly, in the NMDS ordination, the communities of open and fenced plots did not differentiate along the first axis, which paralleled the species richness gradient, but along the second NMDS axis. In 2018, typical dwarf shrub species (e.g. Vaccinium spp.) occupied the upper part of the ordination space related to fenced plots, whereas gap-dependent species characteristic of matgrass communities (e.g. Nardus stricta, Amica montana) occurred in the lower part of the ordination space associated with open plots (Figs 2d, S6).

In accordance with the changes in community composition detected in the multivariate analyses, the recorded structural vegetation characteristics responded significantly to red deer exclusion in heathlands, i.e. sward height in the fenced plots increased, while the cover of bare soil decreased. Additionally, in the final study year, the biomass contribution of Calluna, the height of the litter layer and the number of woody individuals (mainly saplings belonging to Pinus sylvestris and a minor fraction of the genera Betula, Picea, Salix and Rubus; mean height $26.3 \mathrm{~cm}$ in open and $44.3 \mathrm{~cm}$ in fenced plots) were significantly elevated in the fenced plots (Fig. S8). These findings suggest that in consequence of the red deer grazing exclusion, heathlands in GTA become prone to succession, involving potentially serious consequences for conservation. In Germany, a favourable conservation status is attributed to the habitat type European dry heaths if the cover of bare soil ranges between 5 and 25\% (Bundesamt für Naturschutz 2017) because bare soil is essential for many animal (Bell et al. 2001; Cameron and Leather 2012) as well as plant and cryptogam species (Chytrý et al. 2001; Henning et al. 2017). In our experiment, the bare soil cover in the open heathland plots was constantly within the range required for a favourable conservation status, whereas the bare soil cover fell below that range in the fenced plots in 2017. This indicates that red deer grazing might be crucial for maintaining suitable habitat conditions for a diverse flora and fauna in heathlands.

Moreover, the increasing vegetation height and biomass contribution of Calluna plants in the fenced plots in our experiment could represent first signs of a beginning overaging process, which, in the long run, can result in reduced vitality and, finally, dieback of Calluna plants (Barclay-Estrup 1970). Red deer removing a considerable proportion of the annual productivity in heathlands (Riesch et al. 2019) can hence contribute to a vital population of Calluna by preventing the transition to mature or degenerate life history stages. For the same reason, livestock grazing at appropriate stocking rates has long-since been valued as a suitable management strategy for heathlands (Gimingham 1992; Fagúndez 2012).

As the progressive succession towards woodlands is a major threat to heathlands (Bullock and Pakeman 1997; Fagúndez 2012), the strikingly effective suppression of woody species by red deer in GTA (Fig. 6) seems very promising to conservation practice. Among livestock species, only goats have been highlighted for efficiently 
counteracting the encroachment of woody species (Ascoli et al. 2013; Elias and Tischew 2016), whereas cattle, for example, could not prevent the succession towards forest in Dutch heathlands (Bokdam and Gleichman 2000). In sum, our results do not substantiate concerns about the impact of red deer on heathlands, as especially expressed for Scottish heathlands (Albon et al. 2007; DeGabriel et al. 2011), but instead point towards various benefits to vegetation structure. As we did not observe any changes in heathland plant species richness and diversity related to red deer exclusion but a significant change in species composition, future studies should monitor the vegetation development in heathlands with and without red deer grazing over a longer period.

\section{Conclusions}

Comparing the vegetation development in open and fenced plots over almost three years, we found support for our overarching hypothesis that the conservation value of habitats diminished following red deer exclusion because of missing grazing benefits to vegetation structure and diversity. Specifically, as postulated in hypothesis (i), our study confirmed benefits of grazing by wild red deer for plant diversity in the Natura 2000 habitat type lowland hay meadows. This result echoes the global pattern arising from exclusion experiments worldwide that grazing by large herbivores enhances grassland diversity (Jia et al. 2018). In the habitat type European dry heaths, by contrast, we saw a significant change in species composition but no changes in species richness or diversity related to grazing exclusion. In both habitat types, however, we found compelling evidence supporting our hypothesis (ii) because the vegetation structure in the fenced plots developed indications of succession, such as increasing vegetation height, litter accumulation and, in heathlands, disappearance of bare soil and encroachment of woody species. Our study therefore confirmed the influence of large herbivores on successional pathways in open habitats (Brinkert et al. 2016). In hypothesis (iii), we expected that red deer exclusion in grasslands would cause the most pronounced effects where additional management was applied. We could confirm this hypothesis for the $\mathrm{M}$ treatment where the highest frequency of red deer occurrence was recorded. Since the relative attractiveness of a habitat and its spatial arrangement with other habitat types affect the grazing intensity by red deer (Moore et al. 2015), mowing certain areas has been suggested as a strategy to attract red deer and thereby increase their use of adjacent habitats, based on the elevated productivity and forage quality in mown grassland (Riesch et al. 2019). Regarding grassland conservation, red deer grazing combined with annual mowing might be an especially beneficial management regime (Fig. 1), as in our experiment, diversity remained at the initial level only in the open plots of the $\mathrm{M}$ treatment, whereas diversity decreased in all other cases.

Overall, our study provides evidence that grazing by wild red deer can be judged favourably from the conservation perspective not only for understorey vegetation (Hegland et al. 2013; Hegland and Rydgren 2016; Boulanger et al. 2018) but also for different open habitat types. Consequently, our results advocate for grazing by wild red deer as a promising additional tool that could enrich the existing toolkit available 
for the conservation management of semi-natural open habitats and simultaneously permit the restoration of natural grazing regimes and ecological processes.

\section{Acknowledgments}

The project was supported by funds of German government's Special Purpose Fund held at Landwirtschaftliche Rentenbank [28 RZ 7007]. We thank the Federal Forests Division (Bundesforst) of the German Institute for Federal Real Estate

(Bundesanstalt für Immobilienaufgaben) and the Institut für Wildbiologie Göttingen und Dresden e.V. for close cooperation and support. Special thanks go to Nina Rohwer and Luise Emma Gisela Sindl for compiling the PlotWatcher dataset, and Laura Richter and Christoph Raab for their help with camera installation and fieldwork.

\section{Conflict of Interest}

The authors declare that they have no conflict of interest. 


\section{References}

Adler P, Raff D, Lauenroth W. 2001. The effect of grazing on the spatial heterogeneity of vegetation. Oecologia 128:465-479.

Albon SD, Brewer MJ, O’Brien S, Nolan AJ, Cope D. 2007. Quantifying the grazing impacts associated with different herbivores on rangelands. Journal of Applied Ecology 44:11761187.

Allred BW, Fuhlendorf SD, Engle DM, Elmore RD. 2011. Ungulate preference for burned patches reveals strength of fire-grazing interaction. Ecology and Evolution 1:132-144.

Ascoli D, Lonati M, Marzano R, Bovio G, Cavallero A, Lombardi G. 2013. Prescribed burning and browsing to control tree encroachment in southern European heathlands. Forest Ecology and Management 289:69-77.

Bakker ES, Ritchie ME, Olff H, Milchunas DG, Knops JMH. 2006. Herbivore impact on grassland plant diversity depends on habitat productivity and herbivore size. Ecology Letters 9:780_ 788.

Barclay-Estrup P. 1970. The description and interpretation of cyclical processes in a heath community: II. Changes in biomass and shoot production during the Calluna cycle. The Journal of Ecology:243-249.

Beguin J, Tremblay J-P, Thiffault N, Pothier D, Côté SD. 2016. Management of forest regeneration in boreal and temperate deer-forest systems: challenges, guidelines, and research gaps. Ecosphere 7:1-16.

Bell JR, Wheater CP, Cullen WR. 2001. The implications of grassland and heathland management for the conservation of spider communities: a review. Journal of Zoology 255:377-387.

Bokdam J, Gleichman JM. 2000. Effects of grazing by free-ranging cattle on vegetation dynamics in a continental north-west European heathland. Journal of Applied Ecology 37:415-431.

Boob M, Truckses B, Seither M, Elsäßer M, Thumm U, Lewandowski I. 2019. Management effects on botanical composition of species-rich meadows within the Natura 2000 network. Biodiversity and Conservation [Internet] [cited 2019 Jan 10]. Available from: https://doi.org/10.1007/s10531-018-01689-1

Boulanger V, Dupouey J-L, Archaux F, Badeau V, Baltzinger C, Chevalier R, Corcket E, Dumas Y, Forgeard F, Mårell A, et al. 2018. Ungulates increase forest plant species richness to the benefit of non-forest specialists. Global Change Biology 24:e485-e495.

Brinkert A, Hölzel N, Sidorova TV, Kamp J. 2016. Spontaneous steppe restoration on abandoned cropland in Kazakhstan: grazing affects successional pathways. Biodiversity and Conservation 25:2543-2561.

Bullock JM, Pakeman RJ. 1997. Grazing of lowland heath in England: Management methods and their effects on healthland vegetation. Biological Conservation 79:1-13.

Bundesamt für Naturschutz, editor. 2017. Bewertungsschemata für die Bewertung des Erhaltungsgrades von Arten und Lebensraumtypen als Grundlage für ein bundesweites FFH-Monitoring. Teil II: Lebensraumtypen nach Anhang I der FFH-Richtlinie (mit Ausnahme der marinen und Küstenlebensräume). Bonn, DE: Bundesamt für Naturschutz.

Bunzel-Drüke M, Böhm C, Finck P, Kämmer G, Luick R, Reisinger E, Riecken U, Riedl J, Scharf M, Zimball O. 2008. "Wilde Weiden”: Praxisleitfaden für Ganzjahresbeweidung in Naturschutz und Landschaftsentwicklung. Bad Sassendorf-Lohne, DE: Arbeitsgem. Biologischer Umweltschutz im Kreis Soest eV (ABU).

Cameron KH, Leather SR. 2012. Heathland management effects on carabid beetle communities: the relationship between bare ground patch size and carabid biodiversity. Journal of Insect Conservation 16:523-535.

Carbutt C, Henwood WD, Gilfedder LA. 2017. Global plight of native temperate grasslands: going, going, gone? Biodiversity and Conservation 26:2911-2932.

Ceaușu S, Hofmann M, Navarro LM, Carver S, Verburg PH, Pereira HM. 2015. Mapping opportunities and challenges for rewilding in Europe. Conservation Biology 29:1017-1027.

Chytrý M, Sedláková I, Tichý L. 2001. Species richness and species turnover in a successional heathland. Applied Vegetation Science 4:89-96.

Cingolani AM, Noy-Meir I, Díaz S. 2005. Grazing Effects on Rangeland Diversity: A Synthesis of Contemporary Models. Ecological Applications 15:757-773. 
Correll O, Isselstein J, Pavlu V. 2003. Studying spatial and temporal dynamics of sward structure at low stocking densities: the use of an extended rising-plate-meter method. Grass and Forage Science 58:450-454.

Crofts A, Jefferson RG, editors. 1999. The Lowland Grassland Management Handbook. 2nd ed. English Nature and Wildlife Trusts.

DeGabriel JL, Albon SD, Fielding DA, Riach DJ, Westaway S, Irvine RJ. 2011. The presence of sheep leads to increases in plant diversity and reductions in the impact of deer on heather. Journal of Applied Ecology 48:1269-1277.

Dumont B, Carrère P, Ginane C, Farruggia A, Lanore L, Tardif A, Decuq F, Darsonville O, Louault F. 2011. Plant-herbivore interactions affect the initial direction of community changes in an ecosystem manipulation experiment. Basic and Applied Ecology 12:187-194.

Eichhorn MP, Ryding J, Smith MJ, Gill RMA, Siriwardena GM, Fuller RJ. 2017. Effects of deer on woodland structure revealed through terrestrial laser scanning. Journal of Applied Ecology 54:1615-1626.

Elias D, Tischew S. 2016. Goat pasturing-A biological solution to counteract shrub encroachment on abandoned dry grasslands in Central Europe? Agriculture, Ecosystems \& Environment 234:98-106.

European Environment Agency. 2015. Conservation status of species and habitats by ecosystem type from Habitats Directive Article 17 reporting [Internet]. [cited 2018 Aug 16]. Available from: https://www.eea.europa.eu/data-and-maps/daviz/conservation-status-of-species-and

Fagúndez J. 2012. Heathlands confronting global change: drivers of biodiversity loss from past to future scenarios. Annals of Botany 111:151-172.

Fløjgaard C, De Barba M, Taberlet P, Ejrnæs R. 2017. Body condition, diet and ecosystem function of red deer (Cervus elaphus) in a fenced nature reserve. Global Ecology and Conservation 11:312-323.

García RR, Fraser MD, Celaya R, Ferreira LMM, García U, Osoro K. 2013. Grazing land management and biodiversity in the Atlantic European heathlands: a review. Agroforestry systems 87:19_ 43.

Gimingham CH. 1992. The Lowland Heathland Management Handbook. Peterborough, UK: English Nature.

Halada L, Evans D, Romão C, Petersen J-E. 2011. Which habitats of European importance depend on agricultural practices? Biodiversity and Conservation 20:2365-2378.

Harrison PA, Vandewalle M, Sykes MT, Berry PM, Bugter R, Bello F de, Feld CK, Grandin U, Harrington R, Haslett JR, et al. 2010. Identifying and prioritising services in European terrestrial and freshwater ecosystems. Biodiversity and Conservation 19:2791-2821.

Hegland SJ, Lilleeng MS, Moe SR. 2013. Old-growth forest floor richness increases with red deer herbivory intensity. Forest Ecology and Management 310:267-274.

Hegland SJ, Rydgren K. 2016. Eaten but not always beaten: winners and losers along a red deer herbivory gradient in boreal forest. Journal of Vegetation Science 27:111-122.

Henning K, Oheimb G von, Härdtle W, Fichtner A, Tischew S. 2017. The reproductive potential and importance of key management aspects for successful Calluna vulgaris rejuvenation on abandoned Continental heaths. Ecology and Evolution 7:2091-2100.

Hill MO. 1973. Diversity and Evenness: A Unifying Notation and Its Consequences. Ecology 54:427432.

Hilpold A, Seeber J, Fontana V, Niedrist G, Rief A, Steinwandter M, Tasser E, Tappeiner U. 2018. Decline of rare and specialist species across multiple taxonomic groups after grassland intensification and abandonment. Biodiversity and Conservation 27:3729-3744.

Jäger EJ. 2011. Rothmaler - Exkursionsflora von Deutschland: Gefäßpflanzen: Grundband. Heidelberg, DE: Spektrum Akademischer Verlag.

Jia S, Wang X, Yuan Z, Lin F, Ye J, Hao Z, Luskin MS. 2018. Global signal of top-down control of terrestrial plant communities by herbivores. Proceedings of the National Academy of Sciences 115:6237-6242.

Kahmen S, Poschlod P. 2004. Plant functional trait responses to grassland succession over 25 years. Journal of Vegetation Science 15:21-32. 
Kelemen A, Török P, Valkó O, Miglécz T, Tóthmérész B. 2013. Mechanisms shaping plant biomass and species richness: plant strategies and litter effect in alkali and loess grasslands. Journal of Vegetation Science 24:1195-1203.

Klapp E. 1965. Grünlandvegetation und Standort nach Beispielen aus West-, Mittel-, und Süddeutschland. Berlin, DE: Paul Parey.

Koerner SE, Smith MD, Burkepile DE, Hanan NP, Avolio ML, Collins SL, Knapp AK, Lemoine NP, Forrestel EJ, Eby S, et al. 2018. Change in dominance determines herbivore effects on plant biodiversity. Nature Ecology \& Evolution 2:1925-1932.

Langvatn R, Hanley TA. 1993. Feeding-patch choice by red deer in relation to foraging efficiency. Oecologia 95:164-170.

Lenth R. 2018. emmeans: Estimated Marginal Means, aka Least-Squares Means. R package version 1.3.3 [nternet]. [cited 2019 Feb 7]. Available from: https://CRAN.Rproject.org $/$ package $=$ emmeans

Magurran AE. 2004. Measuring Biological Diversity. 1 edition. Malden, MA, USA: Blackwell Publishing.

Marchiori E, Sturaro E, Ramanzin M. 2012. Wild red deer (Cervus elaphus L.) grazing may seriously reduce forage production in mountain meadows. Italian Journal of Animal Science 11:e9.

Meißner M, Reinecke H, Herzog S. 2013. Vom Wald ins Offenland: Der Rothirsch auf dem Truppenübungsplatz Grafenwöhr. Raum-Zeit-Verhalten, Lebensraumnutzung, Management. 2nd ed. Kassel, DE: Frank Fornaçon.

Milchunas DG, Sala OE, Lauenroth WK. 1988. A Generalized Model of the Effects of Grazing by Large Herbivores on Grassland Community Structure. The American Naturalist 132:87-106.

Moore EK, Britton AJ, Iason G, Pemberton J, Pakeman RJ. 2015. Landscape-scale vegetation patterns influence small-scale grazing impacts. Biological Conservation 192:218-225.

Mysterud A. 2006. The concept of overgrazing and its role in management of large herbivores. Wildlife Biology 12:129-141.

Nakagawa S, Johnson PCD, Schielzeth H. 2017. The coefficient of determination $\mathrm{R}^{2}$ and intra-class correlation coefficient from generalized linear mixed-effects models revisited and expanded. Journal of the Royal Society, Interface 14:20170213.

Oksanen J, Blanchet FG, Kindt R, Legendre P, Minchin PR, O’Hara RB, Simpson GL, Solymos P, Stevens MHH, Wagner H. 2015. vegan: Community Ecology Package. R package version 2.5-3 [nternet]. [cited 2016 Jan 14]. Available from: http:/ /CRAN.Rproject.org/package $=$ vegan

Olff H, Ritchie ME. 1998. Effects of herbivores on grassland plant diversity. Trends in Ecology \& Evolution 13:261-265.

Palmer SCF, Hester AJ. 2000. Predicting spatial variation in heather utilization by sheep and red deer within heather/grass mosaics. Journal of Applied Ecology 37:616-631.

Pausas JG, Bond WJ. 2018. Humboldt and the reinvention of nature. Journal of Ecology:1-7.

Poschlod P, Baumann A, Karlik P. 2009. Origin and development of grasslands in Central Europe. In: Grasslands in Europe of High Nature Value. Zeist, NL: KNNV Publishing; p. 15-25.

Proffitt KM, Hebblewhite M, Peters W, Hupp N, Shamhart J. 2016. Linking landscape-scale differences in forage to ungulate nutritional ecology. Ecological Applications 26:2156-2174.

Putman RJ, Moore NP. 1998. Impact of deer in lowland Britain on agriculture, forestry and conservation habitats. Mammal Review 28:141-164.

R Core Team. 2015. R: A language and environment for statistical computing [Internet]. Vienna, AT: R Foundation for Statistical Computing. Available from: https://www.R-project.org/

Riesch F, Tonn B, Meißner M, Balkenhol N, Isselstein J. 2019. Grazing by wild red deer: Management options for the conservation of semi-natural open habitats. Journal of Applied Ecology 56: 56:1311-1321.

Riesch F, Stroh HG, Tonn B, Isselstein J. 2018. Soil pH and phosphorus drive species composition and richness in semi-natural heathlands and grasslands unaffected by twentieth-century agricultural intensification. Plant Ecology \& Diversity 11:239-253.

Rosenthal G, Schrautzer J, Eichberg C. 2012. Low-intensity grazing with domestic herbivores : a tool for maintaining and restoring plant diversity in temperate Europe. Tuexenia 32:167-205. 
Ruprecht E, Enyedi MZ, Eckstein RL, Donath TW. 2010. Restorative removal of plant litter and vegetation 40 years after abandonment enhances re-emergence of steppe grassland vegetation. Biological Conservation 143:449-456.

Sandom C, Ejrnæs R, Hansen MDD, Svenning J-C. 2014. High herbivore density associated with vegetation diversity in interglacial ecosystems. Proceedings of the National Academy of Sciences 111:4162-4167.

Schütz M, Risch AC, Leuzinger E, Krüsi BO, Achermann G. 2003. Impact of herbivory by red deer (Cervus elaphus L.) on patterns and processes in subalpine grasslands in the Swiss National Park. Forest Ecology and Management 181:177-188.

Simpson EH. 1949. Measurement of diversity. Nature 163:688.

Sittler KL, Parker KL, Gillingham MP. 2019. Vegetation and prescribed fire: Implications for stone's sheep and elk. The Journal of Wildlife Management 83:393-409.

Smolko P, Veselovská A, Kropil R. 2018. Seasonal dynamics of forage for red deer in temperate forests: importance of the habitat properties, stand development stage and overstorey dynamics. Wildlife Biology 2018:1-10.

Sutherland WJ. 2002. Conservation biology: Openness in management. Nature 418:834-835.

Trdan S, Vidrih M. 2007. Quantifying the damage of red deer (Cervus elaphus) grazing on grassland production in southeastern Slovenia. European Journal of Wildlife Research 54:138-141.

Tschöpe O, Wallschläger D, Burkart M, Tielbörger K. 2011. Managing open habitats by wild ungulate browsing and grazing: A case-study in North-Eastern Germany. Applied Vegetation Science 14:200-209.

Van Wieren SE. 1995. The potential role of large herbivores in nature conservation and extensive land use in Europe. Biological Journal of the Linnean Society 56:11-23.

Virtanen R, Edwards GR, Crawley MJ. 2002. Red deer management and vegetation on the Isle of Rum. Journal of Applied Ecology 39:572-583.

Walter WD, Lavelle MJ, Fischer JW, Johnson TL, Hygnstrom SE, VerCauteren KC. 2011. Management of damage by elk (Cervus elaphus) in North America: a review. Wildlife Research 37:630-646.

Wang Y, Naumann U, Eddelbuettel D, Warton D, Byrnes J, Silva R dos S, Niku J, Renner I, Wright S. 2018. mvabund: Statistical Methods for Analysing Multivariate Abundance Data. R package version 4.0.1 [Internet]. [cited 2018 Dec 20]. Available from: https://CRAN.Rproject.org $/$ package $=$ mvabund

Wang Y, Naumann U, Wright ST, Warton DI. 2012. mvabund- an R package for model-based analysis of multivariate abundance data. Methods in Ecology and Evolution 3:471-474.

Warton DI. 2008. Penalized Normal Likelihood and Ridge Regularization of Correlation and Covariance Matrices. Journal of the American Statistical Association 103:340-349.

Warton DI, Thibaut L, Wang YA. 2017. The PIT-trap-A “model-free” bootstrap procedure for inference about regression models with discrete, multivariate responses. PLOS ONE 12:e0181790.

Wilmshurst JF, Fryxell JM, Hudson RJ. 1995. Forage quality and patch choice by wapiti (Cervus elaphus). Behavioral Ecology 6:209-217.

Wilsey BJ, Chalcraft DR, Bowles CM, Willig MR. 2005. Relationships among Indices Suggest That Richness Is an Incomplete Surrogate for Grassland Biodiversity. Ecology 86:1178-1184.

Wrage N, Strodthoff J, Cuchillo HM, Isselstein J, Kayser M. 2011. Phytodiversity of temperate permanent grasslands: ecosystem services for agriculture and livestock management for diversity conservation. Biodiversity and Conservation 20:3317-3339. 


\section{Supporting Information to the paper}

Grazing by wild red deer maintains characteristic vegetation of semi-natural open habitats: Evidence from a 3-year exclusion experiment

F. Riesch*, B. Tonn, H. G. Stroh, M. Meißner, N. Balkenhol and J. Isselstein

*Corresponding author, Friederike Riesch, Grassland Science, Department of Crop Sciences, University of Goettingen, 37075 Göttingen, Germany, friederike.riesch@agr.uni-goettingen.de

\section{Supplementary figures}

Fig. S1. Map of study location Grafenwöhr military training area.

Fig. S2. Mean temperature and precipitation during the study years in Grafenwöhr military training area in Bavaria, Germany.

Fig. S3. Berger-Parker index of grassland plant communities.

Fig. S4. Species richness, Inverse Simpson index and Berger-Parker index of heathland plant communities.

Fig. S5. Biomass contribution of Calluna vulgaris in heathlands.

Fig. S6. NMDS ordinations of species in grassland and heathland plant communities.

Fig. S7. Exemplary photograph of a fenced plot in grasslands.

Fig. S8. Exemplary photograph of a fenced plot in heathlands.

\section{Supplementary tables}

Table S1. LME model results for the Berger-Parker index in grasslands and the biomass contribution of Calluna vulgaris in heathlands.

Table S2. Estimated marginal means and $p$-values associated with pairwise comparisons between open and fenced plots.

Table S3. List of plant species recorded in grasslands and heathlands in Grafenwöhr military training area in 2018. 


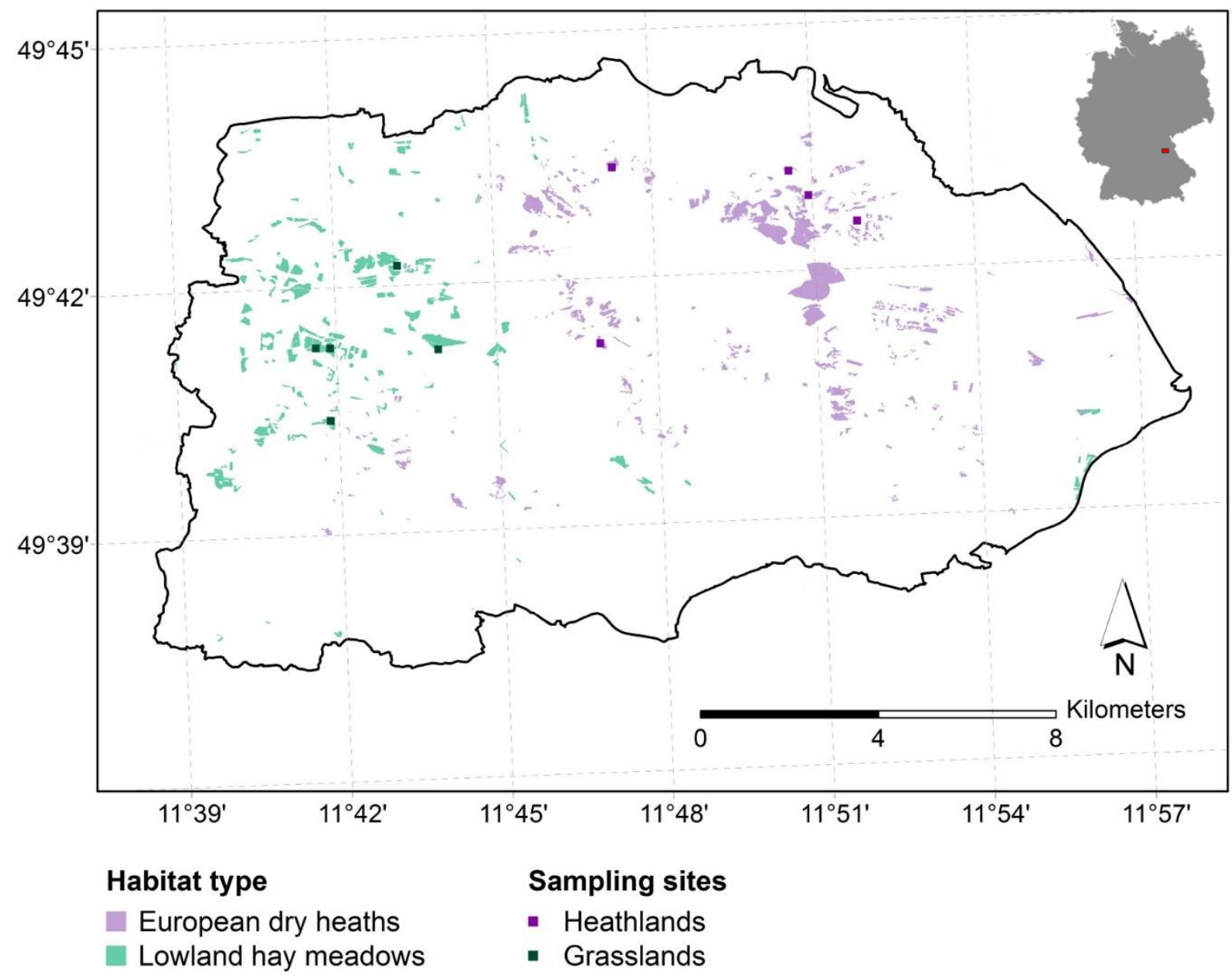

Figure S1: Location of the sampling sites in heathlands and grasslands at Grafenwöhr military training area in Bavaria, Germany. Shaded areas indicate the occurrence of the Natura 2000 habitat types 4030, European dry heaths, and 6510, lowland hay meadows, according to the draft of the Natura 2000 management plan (2013/2014) for the Site of Community Importance and Special Area of Conservation (DE6336301) US-Truppenübungsplatz Grafenwöhr (Riesch et al. (2019), adapted from Riesch et al. (2018)). 


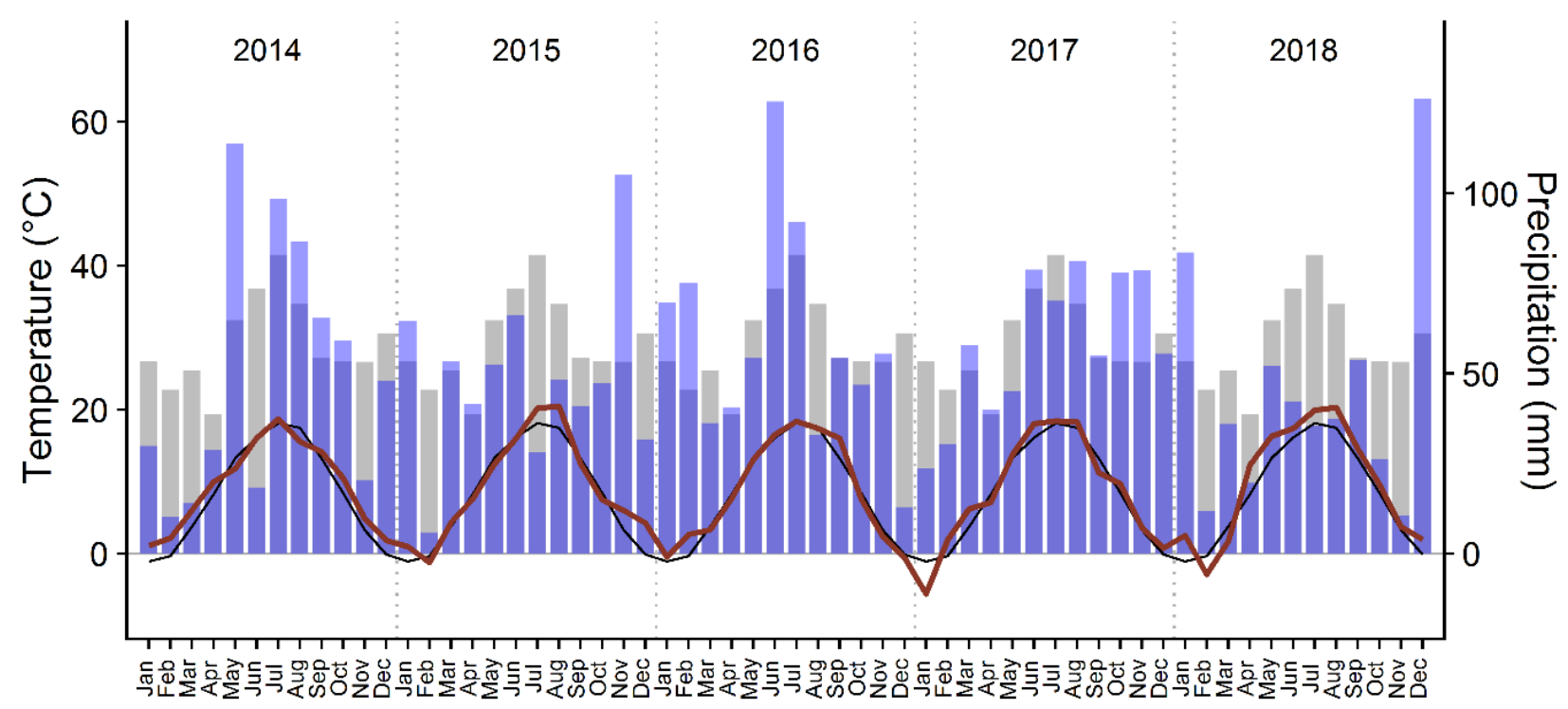

Figure S2: Mean temperature $\left({ }^{\circ} \mathrm{C}\right.$, blue bars) and precipitation ( $\mathrm{mm}$, red line) during the study years, 2014 to 2018, in Grafenwöhr military training area in Bavaria, Germany (averaged over four weather stations of the German Weather Service (Deutscher Wetterdienst, DWD) in the immediate vicinity). The grey bars and the black line show the 1981-2010 long-term average temperature and precipitation, respectively. 


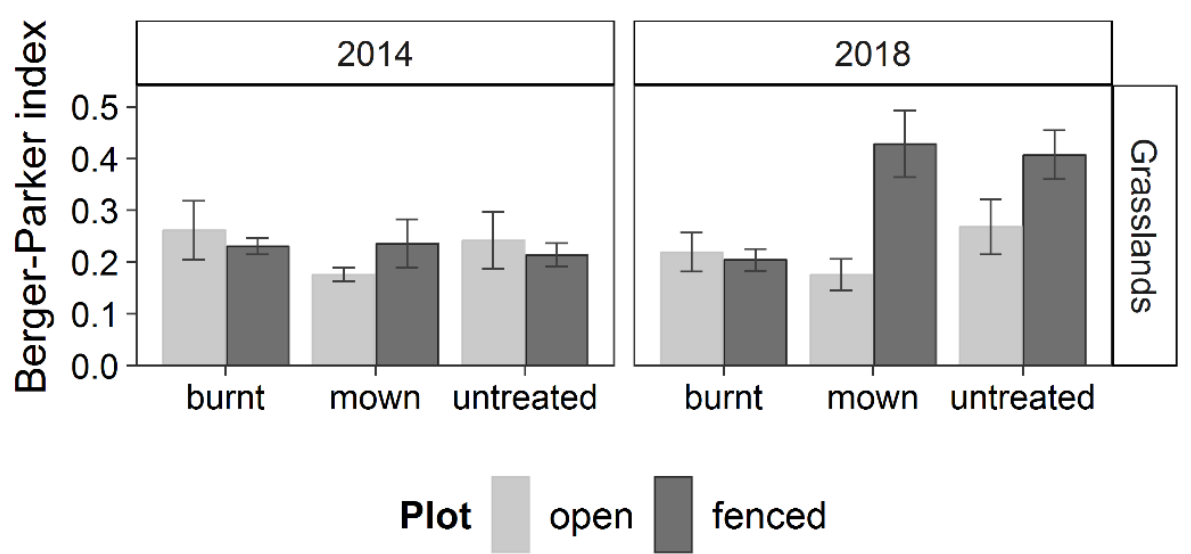

Figure S3: Mean and standard error of the Berger-Parker index of plant communities in relevés $\left(25 \mathrm{~m}^{2}\right)$ within plots open to or protected against red deer grazing (fenced) in burnt, mown and untreated grasslands $(n=5)$ in Grafenwöhr military training area in 2014 before the beginning of the experiment and 2018 after more than 30 months of red deer exclusion. 
(a)

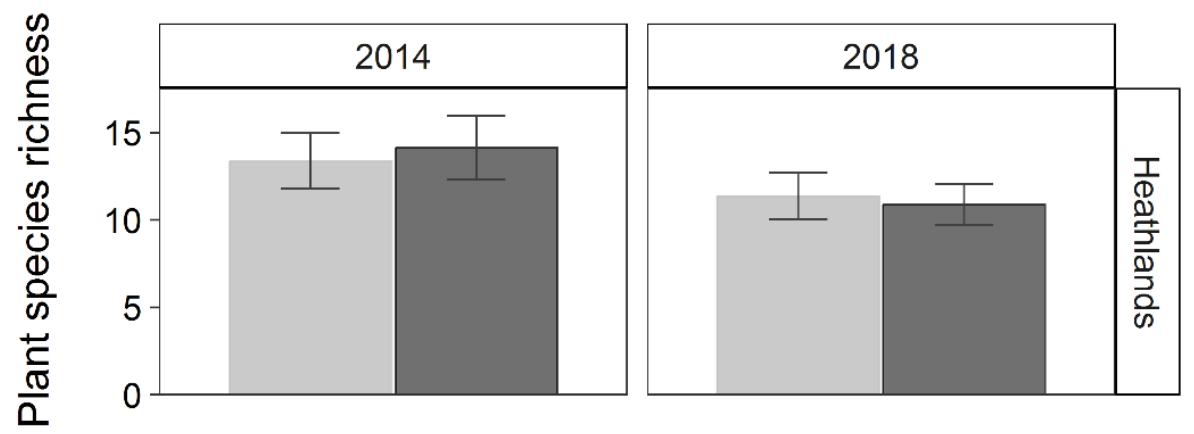

(b)
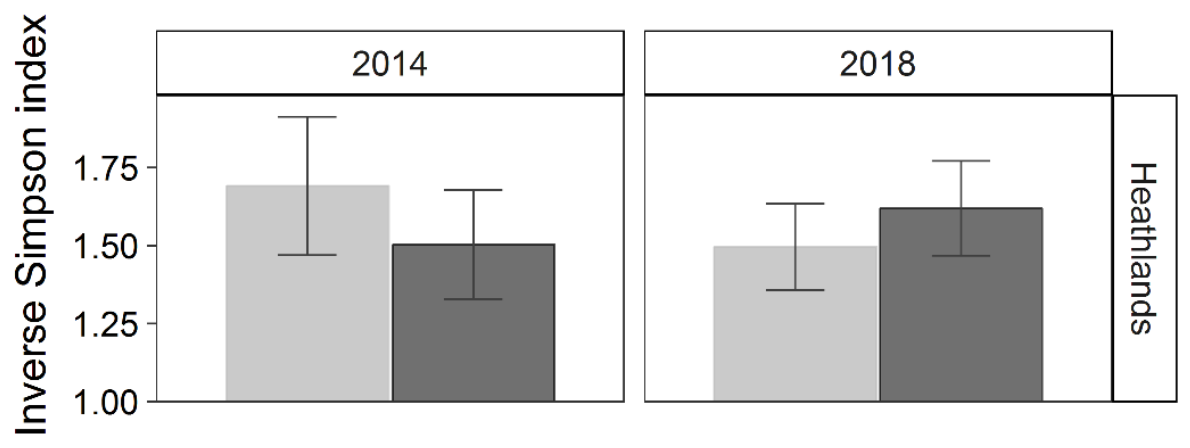

(c)

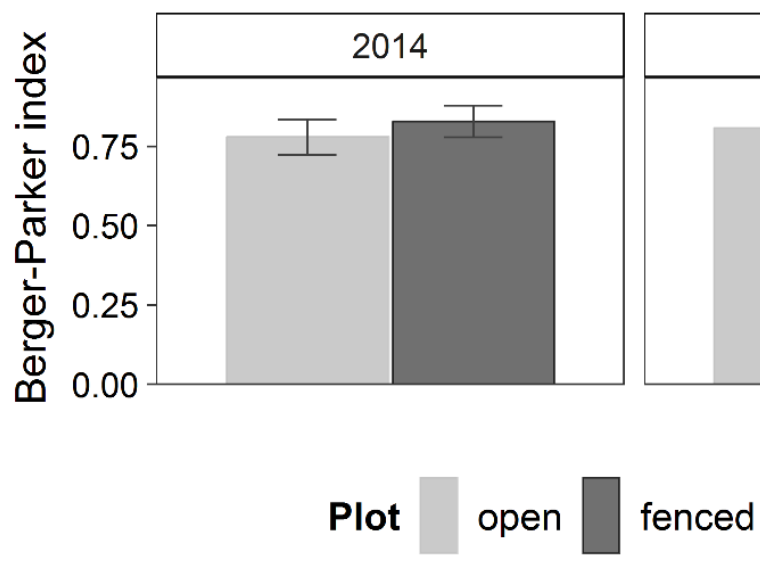

Figure S4: Mean and standard error of plant species richness, Inverse Simpson index and Berger-Parker index of plant communities in relevés $\left(25 \mathrm{~m}^{2}\right)$ within plots open to or protected against red deer grazing (fenced) in heathlands $(n=8)$ in Grafenwöhr military training area in 2014 before the beginning of the experiment and 2018 after more than 30 months of red deer exclusion (cf. Table S1). 

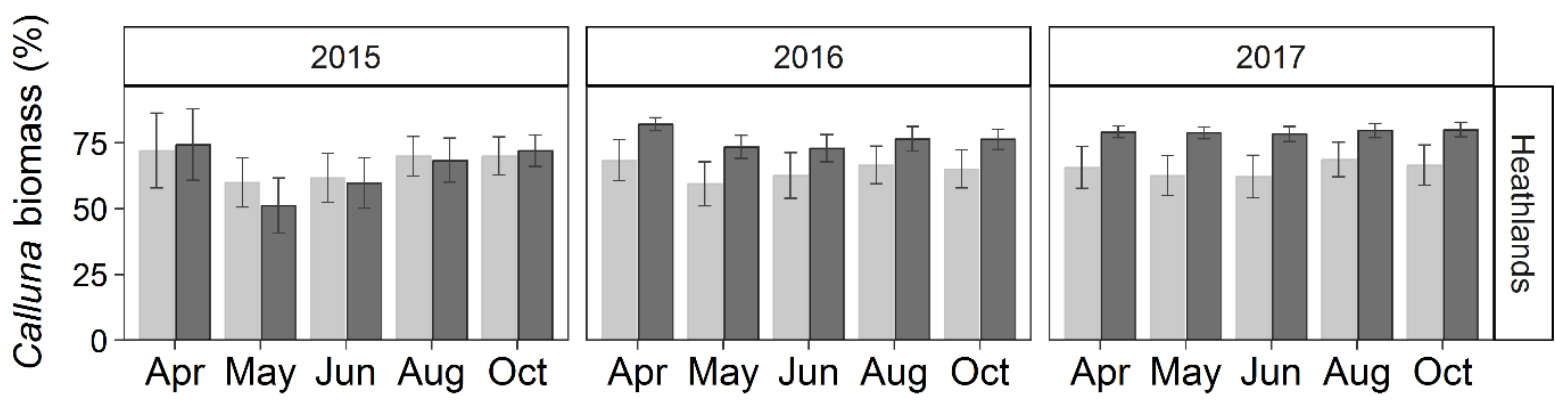

Plot open fenced

Figure S5: Percent contribution (mean $\pm \mathrm{SE}$ ) of Calluna vulgaris to the total aboveground plant biomass in sampling plots open to or protected against red deer grazing (fenced) in heathlands $(n=8)$ in Grafenwöhr military training area estimated at five dates per vegetation period in 2015-2017 (cf. Table S1). 
(a)

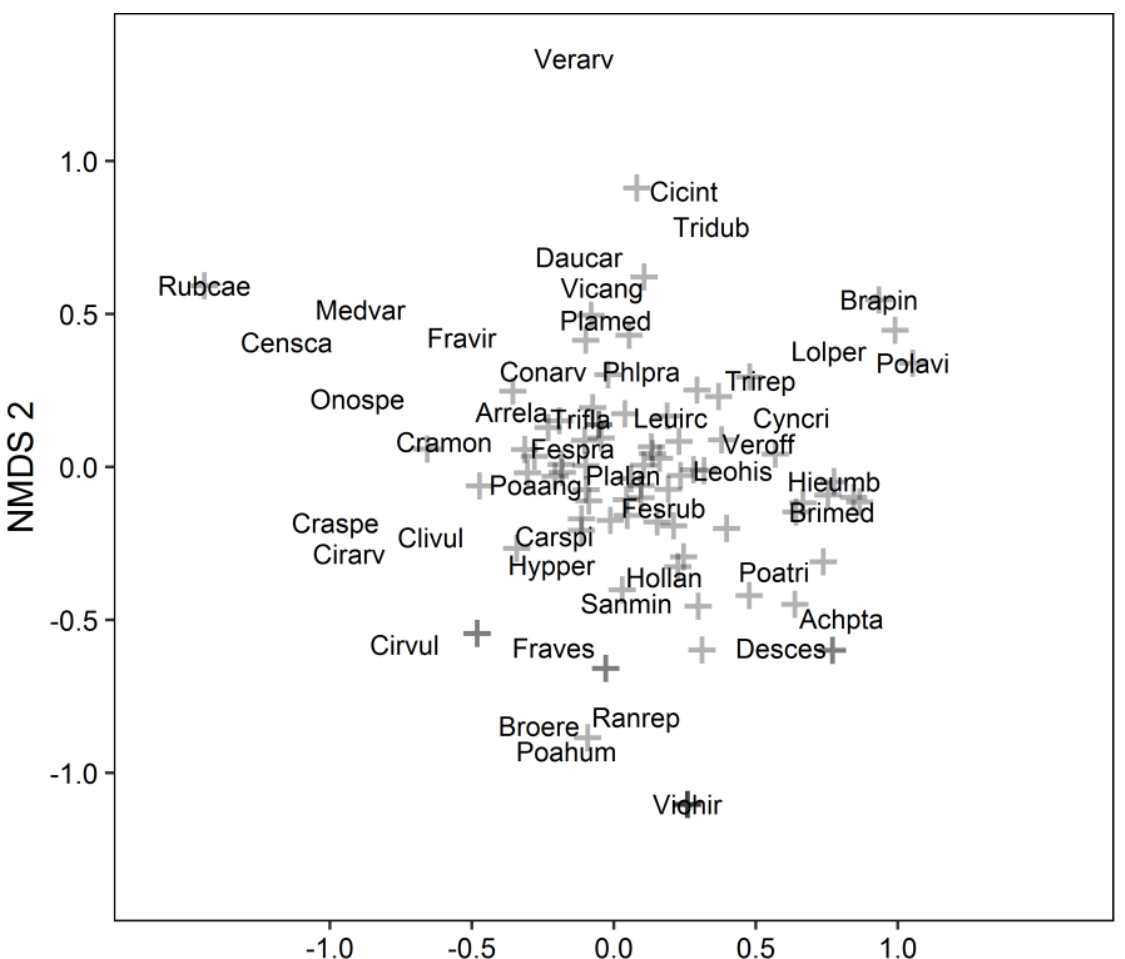

(b)

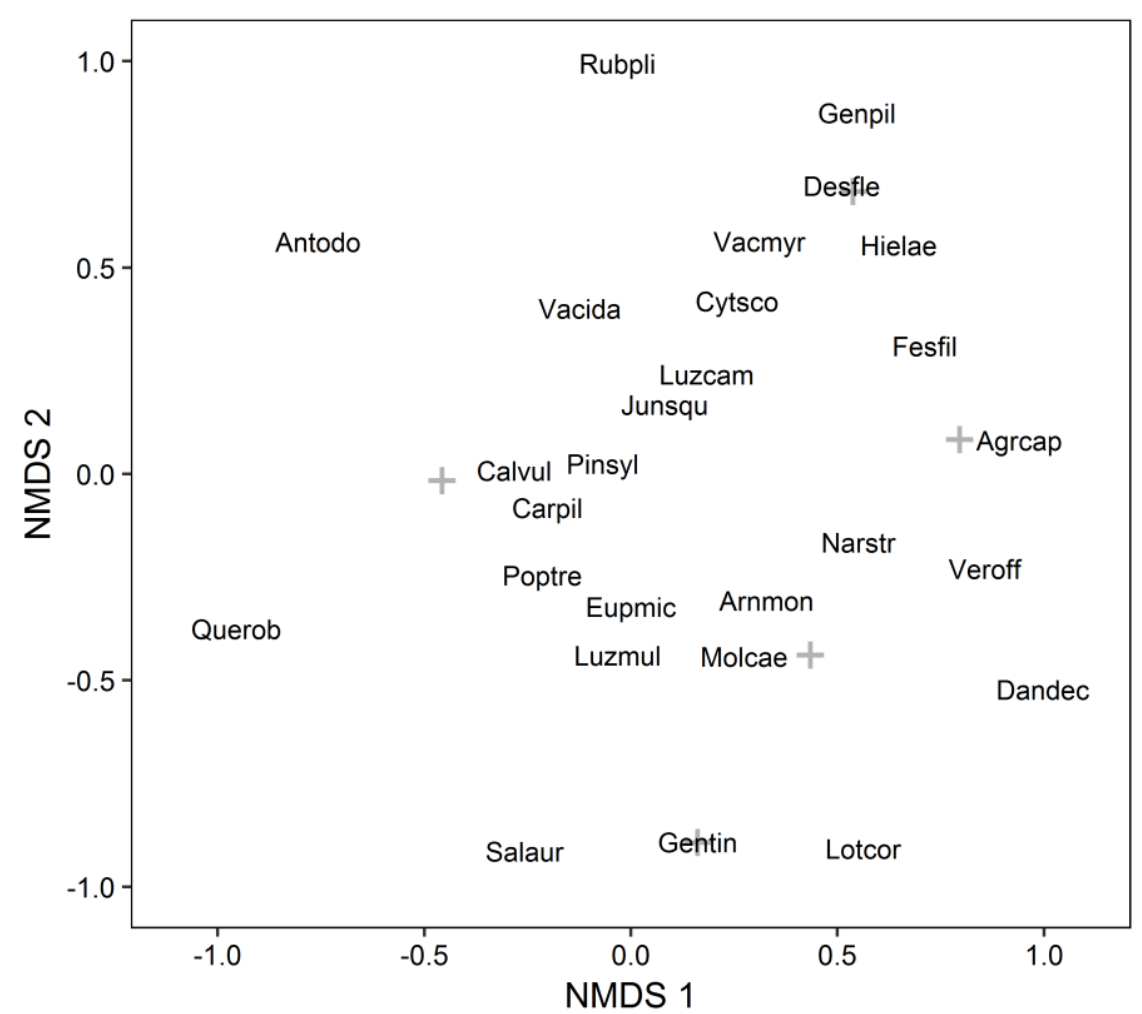

Figure S6: Two-dimensional NMDS ordinations of species in (a) grassland and (b) heathland plant communities in Grafenwöhr military training area in 2018 after more than 30 months of red deer exclusion. If nametags overlapped, the name of the species with the highest abundance was printed, while the other species were represented by ' + '. See Table S3 for the abbreviations of species names. 


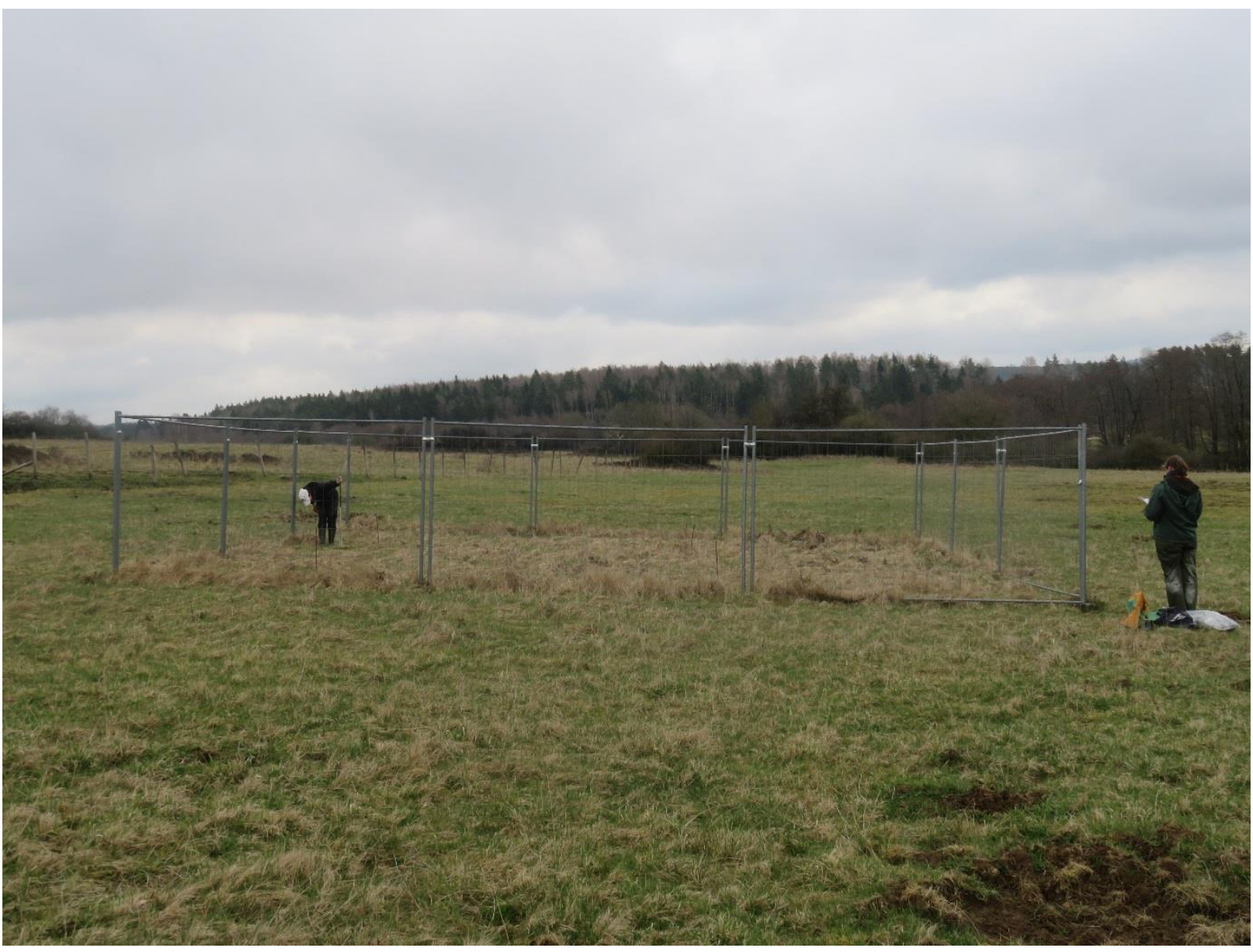

Figure S7: Exemplary picture of a fenced plot in untreated grasslands in Grafenwöhr military training area. The picture was taken in April 2018 after more than 30 months of red deer exclusion. 


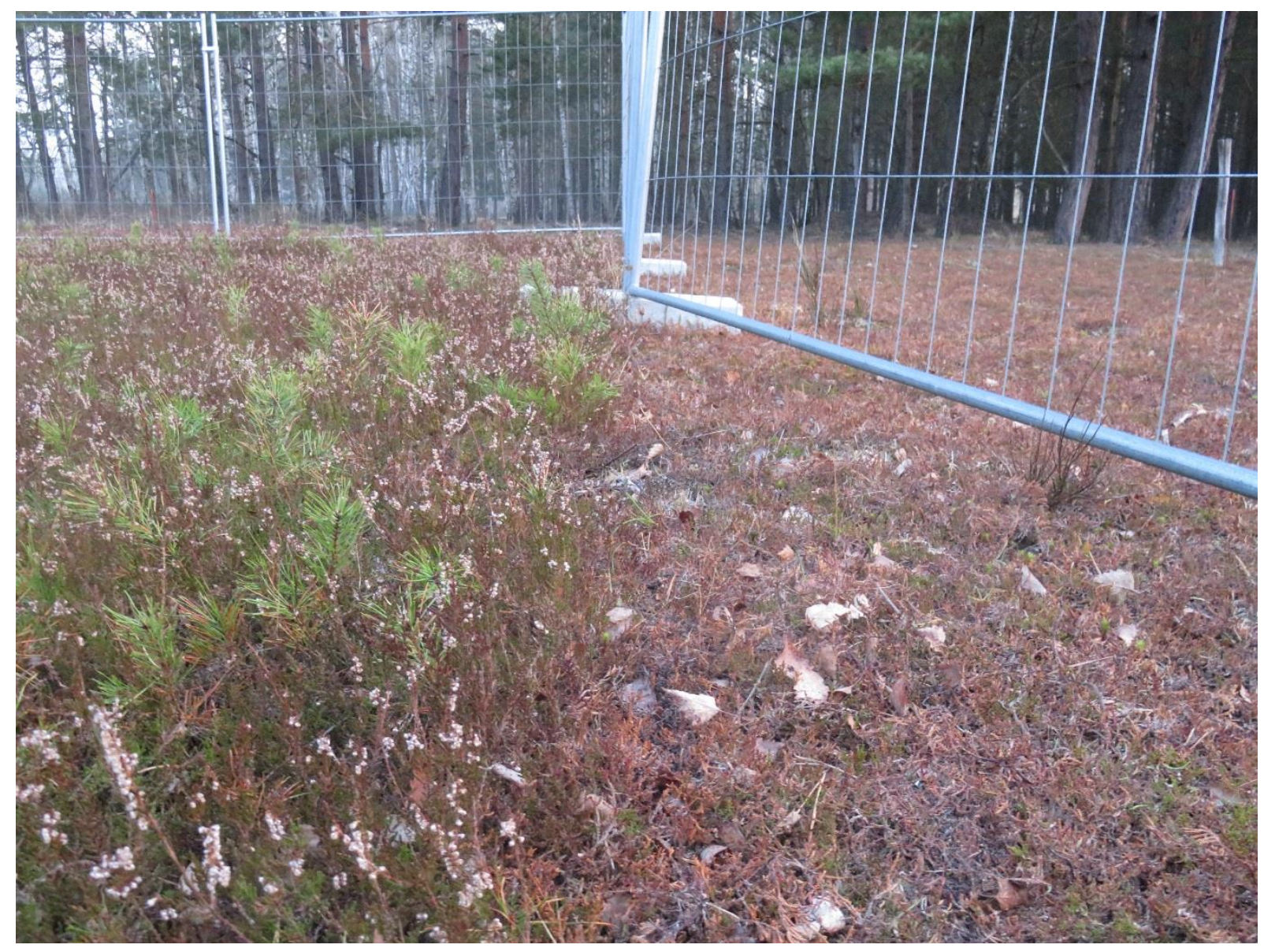

Figure S8: Exemplary photograph of heathland vegetation grazed by wild red deer (right) and protected from grazing inside a fenced plot (left) in Grafenwöhr military training area. The picture was taken in April 2018 after more than 30 months of red deer exclusion. 
Table S1: Results of linear mixed models analysing the effect of red deer exclusion on the Berger-Parker index in grasslands and on the percent biomass contribution of Calluna vulgaris to the total aboveground plant biomass in heathlands. Numerator $\left(d f_{(\text {num })}\right)$ and denominator degrees of freedom $\left(d f_{(\mathrm{den})}\right), F$ - and $p$-values for sequential Wald tests for the factors retained in the most parsimonious models including each model's marginal $R_{(m)^{2}}$ and conditional coefficient of determination $R_{(c)^{2}}$ according to Nakagawa et al. (2017).

\begin{tabular}{|c|c|c|c|c|c|c|c|c|}
\hline Response & Habitat type & Factor & $d f_{\text {(num) }}$ & $d f_{(\mathrm{den})}$ & $F$ & $p$-value ${ }^{e}$ & $R_{(m)}^{2}$ & $R_{(c)}^{2}$ \\
\hline \multirow{6}{*}{$\begin{array}{l}\text { Berger-Parker } \\
\text { index }\end{array}$} & \multirow[t]{6}{*}{ Grasslands } & Plot $^{\mathrm{a}}$ & 1 & 12 & 7.29 & 0.019 & \multirow[t]{6}{*}{0.39} & \multirow[t]{6}{*}{0.45} \\
\hline & & Yearb & 1 & 26 & 6.02 & 0.021 & & \\
\hline & & Treatment ${ }^{c}$ & 2 & 8 & 1.77 & 0.231 & & \\
\hline & & Plot $\times$ Year & 1 & 26 & 7.23 & 0.012 & & \\
\hline & & Plot $\times$ Treatment & 2 & 12 & 4.97 & 0.027 & & \\
\hline & & Year $\times$ Treatment & 2 & 26 & 3.88 & 0.034 & & \\
\hline \multirow{5}{*}{$\begin{array}{l}\text { Calluna } \\
\text { biomass (\%) }\end{array}$} & \multirow[t]{5}{*}{ Heathlands } & Plot & 1 & 7 & 5.74 & 0.048 & \multirow[t]{5}{*}{0.05} & \multirow[t]{5}{*}{0.35} \\
\hline & & Year & 2 & 208 & 0.51 & 0.600 & & \\
\hline & & Month $^{\mathrm{d}}$ & 4 & 208 & 8.16 & $\leq 0.001$ & & \\
\hline & & Plot $\times$ Year & 2 & 208 & 10.91 & $\leq 0.001$ & & \\
\hline & & Year $\times$ Month & 8 & 208 & 3.85 & $\leq 0.001$ & & \\
\hline
\end{tabular}

aType of plot; factor (open/fenced)

bStudy year; factor $(2015,2016,2017)$

'Treatments in grasslands; factor (burnt/mown/untreated)

dMonth of sampling; factor (April/May/June/August/October)

eBold type face indicates statistical significance $(p<0.05)$ 
Table S2: Estimated marginal means for open $(\mathrm{O})$ and fenced $(\mathrm{F})$ plots calculated for significant model terms including the explanatory variable 'Plot' $(p \leq 0.05)$ in the most parsimonious linear mixed effects models for plant diversity and vegetation structure response variables in grasslands and heathlands (c.f. Table 2 and Table S1). $P$-values are associated with the pairwise comparison between open and fenced plots.

\begin{tabular}{|c|c|c|c|c|c|c|c|c|}
\hline Response & $\begin{array}{l}\text { Habitat } \\
\text { type }\end{array}$ & Model term & Year & Month $^{a}$ & Treatment $^{\mathrm{b}}$ & Plot & Estimate & $p$-value ${ }^{c}$ \\
\hline \multirow{4}{*}{$\begin{array}{l}\text { Species } \\
\text { richness }\end{array}$} & \multirow[t]{4}{*}{ Grasslands } & \multirow[t]{4}{*}{ Plot $\times$ Year } & \multirow[t]{2}{*}{2014} & - & - & $\mathrm{O}$ & 46.8 & \multirow{2}{*}{0.378} \\
\hline & & & & - & - & $\mathrm{F}$ & 48.1 & \\
\hline & & & \multirow[t]{2}{*}{2018} & - & - & $\mathrm{O}$ & 41.0 & \multirow{2}{*}{0.058} \\
\hline & & & & - & - & F & 38.2 & \\
\hline \multirow{10}{*}{$\begin{array}{l}\text { Inverse } \\
\text { Simpson } \\
\text { Index }\end{array}$} & \multirow[t]{10}{*}{ Grasslands } & \multirow[t]{4}{*}{ Plot $\times$ Year } & \multirow[t]{2}{*}{2014} & - & - & $\mathrm{O}$ & 10.4 & \multirow{2}{*}{0.927} \\
\hline & & & & - & - & $\mathrm{F}$ & 10.3 & \\
\hline & & & \multirow[t]{2}{*}{2018} & - & - & $\mathbf{O}$ & 10.1 & \multirow{2}{*}{0.003} \\
\hline & & & & - & - & F & 6.5 & \\
\hline & & \multirow{6}{*}{$\begin{array}{l}\text { Plot } \times \\
\text { Treatment }\end{array}$} & - & - & B & $\mathrm{O}$ & 9.6 & \multirow{2}{*}{0.756} \\
\hline & & & - & - & & F & 10.0 & \\
\hline & & & - & - & $\mathbf{M}$ & $\mathbf{O}$ & 12.2 & \multirow{2}{*}{0.002} \\
\hline & & & - & - & & F & 7.5 & \\
\hline & & & - & - & U & $\mathrm{O}$ & 9.0 & \multirow{2}{*}{0.328} \\
\hline & & & - & - & & F & 7.7 & \\
\hline \multirow{10}{*}{$\begin{array}{l}\text { Berger- } \\
\text { Parker } \\
\text { Index }\end{array}$} & \multirow[t]{10}{*}{ Grasslands } & \multirow[t]{4}{*}{ Plot $\times$ Year } & 2014 & - & - & $\mathrm{O}$ & 0.2 & \multirow{2}{*}{0.993} \\
\hline & & & & - & - & $\mathrm{F}$ & 0.2 & \\
\hline & & & \multirow[t]{2}{*}{2018} & - & - & $\mathbf{O}$ & 0.2 & \multirow{2}{*}{0.002} \\
\hline & & & & - & - & F & 0.3 & \\
\hline & & \multirow{6}{*}{$\begin{array}{l}\text { Plot } \times \\
\text { Treatment }\end{array}$} & - & - & B & $\mathrm{O}$ & 0.2 & 0,576 \\
\hline & & & - & - & & $\mathrm{F}$ & 0.2 & 0.070 \\
\hline & & & - & - & $\mathbf{M}$ & $\mathbf{O}$ & 0.2 & 0.002 \\
\hline & & & - & - & & F & 0.3 & \\
\hline & & & - & - & U & $\mathrm{O}$ & 0.3 & 0.193 \\
\hline & & & - & - & & F & 0.3 & \\
\hline Compressed & Grasslands & Plot $\times$ Year & 2015 & - & B & $\mathrm{O}$ & 12.5 & 0.346 \\
\hline sward & & $\times$ Treatment & & - & & $\mathrm{F}$ & 12.0 & \\
\hline & & & & - & M & $\mathrm{O}$ & 8.4 & 0740 \\
\hline & & & & - & & $\mathrm{F}$ & 8.5 & \\
\hline & & & & - & $\mathrm{U}$ & $\mathrm{O}$ & 11.3 & 0377 \\
\hline & & & & - & & F & 11.7 & - \\
\hline & & & 2016 & - & B & $\mathbf{O}$ & 13.3 & 0001 \\
\hline & & & & - & & $\mathbf{F}$ & 16.4 & 0.001 \\
\hline & & & & - & $\mathbf{M}$ & $\mathbf{O}$ & 7.8 & $<0001$ \\
\hline & & & & - & & $\mathbf{F}$ & 12.2 & -0.001 \\
\hline & & & & - & $\mathbf{U}$ & $\mathbf{O}$ & 13.5 & $<0.001$ \\
\hline & & & & - & & $\mathbf{F}$ & 16.4 & \\
\hline & & & 2017 & - & B & $\mathbf{O}$ & 9.9 & 0,003 \\
\hline & & & & - & & $\mathbf{F}$ & 12.3 & \\
\hline
\end{tabular}




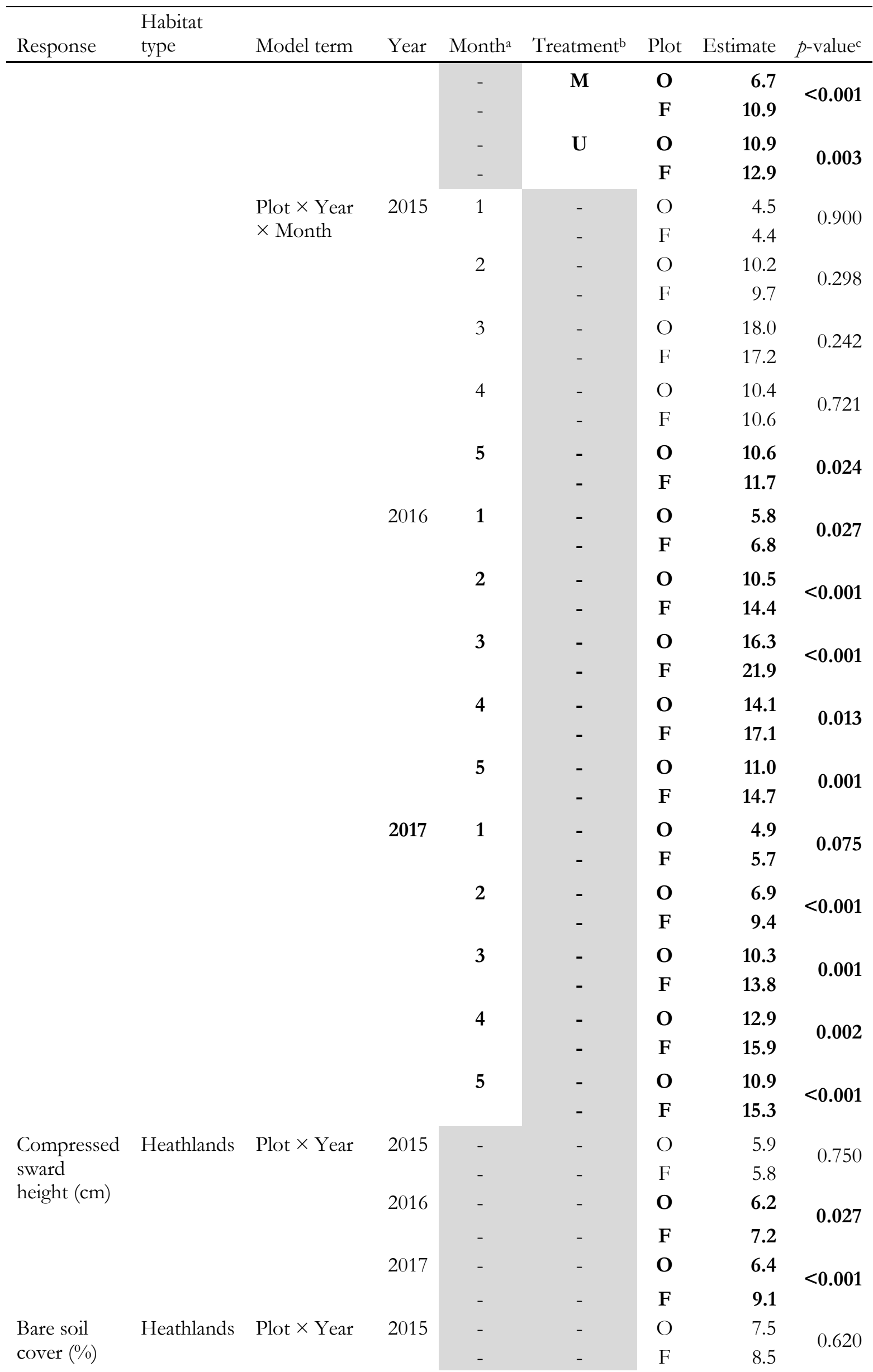




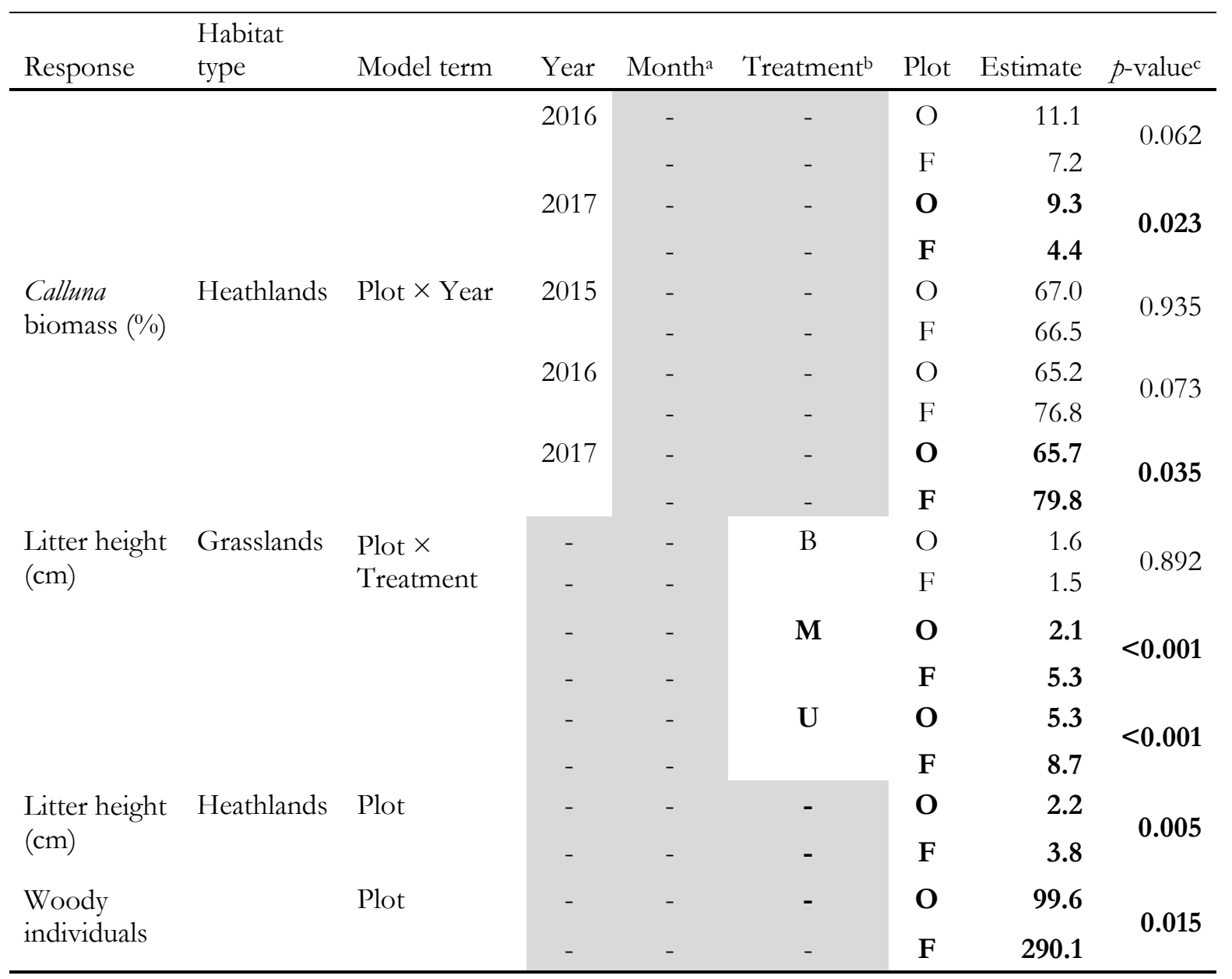

${ }^{a}$ Month of sampling; factor (1, April/2, May/3, June/4, August/5, October)

${ }^{b}$ Treatments in grasslands; factor $(\mathrm{B}$, burnt $/ \mathrm{M}$, mown $/ \mathrm{U}$, untreated)

cBold type face indicates statistical significance $(p<0.05)$ 
Table S3: List of plant species recorded in grasslands and heathlands in Grafenwöhr military training area in 2018 on 30 and 16 relevés of $25 \mathrm{~m}^{2}$, respectively. Abbreviations of species names or symbol ' + ' relate to the representation in Fig. S6.

\begin{tabular}{|c|c|c|}
\hline Species & Grasslands & Heathlands \\
\hline Achillea millefolium & + & \\
\hline Acbillea ptarmica & Achpta & \\
\hline Agrimonia eupatoria & + & \\
\hline Agrostis capillaris & + & Agrcap \\
\hline Ajuga reptans & + & \\
\hline Alchemilla glaucescens & + & \\
\hline Alchemilla monticola & + & \\
\hline Allium vineale & + & \\
\hline Alopecurus pratensis & + & \\
\hline Anthoxanthum odoratum & + & Antodo \\
\hline Anthriscus sylvestris & + & \\
\hline Arnica montana & & Arnmon \\
\hline Arrhenatherum elatius & Arrela & \\
\hline Bellis perennis & + & \\
\hline Betonica officinalis & + & \\
\hline Betula pendula & & + \\
\hline Brachvpodium pinnatum & Brapin & \\
\hline Briza media & Brimed & \\
\hline Bromus erectus & Broere & \\
\hline Bromus hordeaceus ssp. hordeaceus & + & \\
\hline Calluna vulgaris & & Calvul \\
\hline Campanula glomerata & + & \\
\hline Campanula patula & + & \\
\hline Campanula rotundifolia & + & \\
\hline Cardamine pratensis & + & \\
\hline Carex carvophyllea & + & \\
\hline Carex flacca & + & \\
\hline Carex hirta & + & \\
\hline Carex ovalis & + & \\
\hline Carex pallescens & + & \\
\hline Carex pilulifera & & Carpil \\
\hline Carex spicata & Carspi & \\
\hline Centaurea jacea & + & \\
\hline Centaurea scabiosa & Censca & \\
\hline Cerastium arvense & + & \\
\hline Cerastium holosteoides & + & \\
\hline Chenopodium album & + & \\
\hline Cichorium intvbus & Cicint & \\
\hline Cirsium arvense & Cirarv & \\
\hline Cirsium vulgare & Cirvul & \\
\hline Clinopodium vulgare & Clivul & \\
\hline Convolvulus arvensis & Conarv & \\
\hline Crataegus monogvna & Cramon & \\
\hline Crataegus sp. & Craspe & \\
\hline Crepis biennis & + & \\
\hline
\end{tabular}




\begin{tabular}{|c|c|c|}
\hline Species & Grasslands & Heathlands \\
\hline Cruciata laevites & + & \\
\hline Cvnosurus cristatus & Cyncri & \\
\hline Cytisus scoparius & & Cytsco \\
\hline Dactvlis glomerata & + & \\
\hline Danthonia decumbens & & Dandec \\
\hline Daucus carota & Daucar & \\
\hline Deschampsia cespitosa ssp. cespitosa & Desces & \\
\hline Deschampsia flexuosa & & Desfle \\
\hline Dianthus deltoides & + & \\
\hline Elvmus repens ssp. repens & + & \\
\hline Exilobium angustifolium & & + \\
\hline Equisetum arvense & + & \\
\hline Euphorbia cvparissias & + & \\
\hline Euphrasia micrantha & & Eupmic \\
\hline Festuca filiformis & & Fesfil \\
\hline Festuca pratensis & Fespra & \\
\hline Festuca rubra ssp. rubra & Fesrub & \\
\hline Fragaria vesca & Fraves & \\
\hline Fragaria viridis & Fravir & \\
\hline Galium album & + & \\
\hline Galium pumilum & + & + \\
\hline Galium verum & + & \\
\hline Galium $\times$ pommeranicum & + & \\
\hline Genista pilosa & & Genpil \\
\hline Genista tinctoria & & Gentin \\
\hline Glechoma hederacea & + & \\
\hline Helictotrichon pubescens & + & \\
\hline Heracleum sphondvlium & + & \\
\hline Hieracium of laevigatum & & Hielae \\
\hline Hieracium umbellatum & Hieumb & \\
\hline Holcus lanatus & Hollan & \\
\hline Hvpericum maculatum agg. & + & \\
\hline Hvpericum perforatum ssp. perforatum & Hypper & \\
\hline Hvpochaeris radicata & + & \\
\hline Tuncus squarrosus & & Junsqu \\
\hline Knautia arvensis & + & \\
\hline Lathyrus pratensis & + & \\
\hline Leontodon hispidus ssp. hispidus & Leohis & \\
\hline Leucanthemum ircutianum & Leuirc & \\
\hline Linaria vulgaris & + & \\
\hline Lolium perenne & Lolper & \\
\hline Lotus corniculatus & + & Lotcor \\
\hline Luzula campestris & + & Luzcam \\
\hline Luzula multiflora & & Luzmul \\
\hline Lychnis flos cuculi & + & \\
\hline Medicago falcata varia & Medvar & \\
\hline Medicago lupulina & + & \\
\hline Molinia caerulea & & Molcae \\
\hline Nardus stricta & & Narstr \\
\hline
\end{tabular}




\begin{tabular}{|c|c|c|}
\hline Species & Grasslands & Heathlands \\
\hline Odontites rubra & & + \\
\hline Ononis sp. & Onospe & \\
\hline Phleum pratense & Phlpra & \\
\hline Pimpinella saxifraga & + & \\
\hline Pinus sylvestris $\mathrm{ssp}$. sylvestris & & Pinsyl \\
\hline Plantago lanceolata & Plalan & \\
\hline Plantago media & Plamed & \\
\hline Poa angustifolia & Poaang & \\
\hline Poa annua & + & \\
\hline Poa bumilis & Poahum & \\
\hline Poa trivialis & Poatri & \\
\hline Polvgonum aviculare & Polavi & \\
\hline Populus tremula & & Poptre \\
\hline Potentilla argentea & + & \\
\hline Potentilla erecta & & + \\
\hline Potentilla neumanniana & + & \\
\hline Potentilla recta & + & \\
\hline Potentilla reptans & + & \\
\hline Primula veris & + & \\
\hline Prunella vulgaris & + & \\
\hline Prunus sp. & + & \\
\hline Prunus spinosa & + & \\
\hline Pyrus communis & + & \\
\hline Onercus robur & & Querob \\
\hline Ranunculus acris ssp. acris & + & \\
\hline Ranunculus auricomus agg. & + & \\
\hline Ranunculus bulbosus & + & \\
\hline Ranunculus repens & Ranrep & \\
\hline Rhinanthus minor & + & \\
\hline Rosa canina & + & \\
\hline Rubus caesius & Rubcae & \\
\hline Rubus plicatus & & Rubpli \\
\hline Rumex acetosa & + & \\
\hline Rumex crispus & + & \\
\hline Salix aurita & & Salaur \\
\hline Salvia pratensis & + & \\
\hline Sanguisorba minor ssp. minor & Sanmin & \\
\hline Saxifraga granulata & + & \\
\hline Scorzoneroides autumnalis & + & \\
\hline Securigera varia & + & \\
\hline Senecio jacobaea & + & \\
\hline Silaum silaus & + & \\
\hline Stellaria graminea & + & \\
\hline Taraxacum sect. Ruderalia & + & \\
\hline Thvmus pulegioides & + & \\
\hline Tragopogon pratense & + & \\
\hline Trifolium dubium & Tridub & \\
\hline Trifolium medium & + & \\
\hline Trifolium pratense & + & \\
\hline
\end{tabular}




\begin{tabular}{lll}
\hline Species & Grasslands & Heathlands \\
\hline Trifolium repens & Trirep & \\
Trisetum flavescens & Trifla & \\
Vacinium myrtillus & & Vacmvr \\
Vaccinium vitis idaea & & Vacida \\
Veronica arvensis & Verarv & \\
Veronica chamaedrvs & + & \\
Veronica officinalis & Veroff & Veroff \\
Vicia angustifolia & Vicang & \\
Vicia cracca & + & \\
Vicia tetrasperma & + & \\
Viola birta & Viohir & \\
\hline
\end{tabular}




\section{References (Supporting Information)}

Nakagawa S, Johnson PCD, Schielzeth H. 2017. The coefficient of determination $\mathrm{R}^{2}$ and intra-class correlation coefficient from generalized linear mixed-effects models revisited and expanded. Journal of the Royal Society, Interface 14:20170213.

Riesch F, Tonn B, Meißner M, Balkenhol N, Isselstein J. 2019. Grazing by wild red deer: Management options for the conservation of semi-natural open habitats. Journal of Applied Ecology 56:1311-1321.

Riesch F, Stroh HG, Tonn B, Isselstein J. 2018. Soil pH and phosphorus drive species composition and richness in semi-natural heathlands and grasslands unaffected by twentieth-century agricultural intensification. Plant Ecology \& Diversity 11:239-253. 


\section{PART III}

\section{General Discussion}

This thesis set out to improve our understanding of (i) vegetation patterns in open habitats under close-to-natural soil nutrient conditions (Chapter 1) and (ii) vegetation processes and their relationship with grazing by wild red deer in these semi-natural open habitats (Chapter $2 \& 3$ ). The following section highlights and connects the key findings and evaluates how the insights gained from the different studies can contribute to the future conservation of semi-natural open habitats. To support the practical relevance of the research results, the basic conditions required to implement grazing by free-ranging red deer in other areas of high conservation interest receive special attention.

In short, what are the lessons learned and what are the future perspectives for conservation? 


\section{Soil-vegetation patterns in a pre-industrialised landscape}

From a conservation perspective, the main finding of the vegetation survey performed in lowland hay meadows ('grasslands') and European dry heaths ('heathlands') in Grafenwöhr military training area (GTA) was that plant species richness in both habitat types was sensitive to gradients in (different) soil chemical parameters-even though these gradients were short because the analyses were performed at the within-habitat scale and the study area had never been affected by industrialised agriculture (Chapter 1).

Plant species richness in heathlands did not relate to soil nutrient concentrations but responded strongly to soil acidity, increasing linearly with increasing soil $\mathrm{pH}$. This local pattern points to how human alterations of global environmental processes can have consequences for conservation. As atmospheric nitrogen $(\mathrm{N})$ deposition is projected to remain high in the future (Kanakidou et al. 2016), further Ndeposition-related acidification has to be considered as a potentially serious threat to heathland habitat quality (Kleijn et al. 2008), especially considering the fact that rare and endangered plant species are lost when soils become too acidic (Roem and Berendse 2000; Van Den Berg et al. 2005).

By contrast, grasslands plant species richness in GTA decreased with increasing extractable soil phosphorus $(\mathrm{P})$ concentration. This indicates that similar mechanisms as in agriculturally improved grasslands govern the relationship between plantavailable soil $\mathrm{P}$ and plant species richness in unimproved semi-natural grasslands. For instance, increasing P availability can lead to increasing competition for light (Hautier et al. 2009) or for other nutrients that become, in relation to P, less available (Güsewell 2004). This result adds evidence to the relevance of soil P for grassland plant diversity arising from earlier studies, which included much larger gradients in soil P (Janssens et al. 1998; Critchley et al. 2002; Gilbert et al. 2009; Hejcman et al. 2010; Ceulemans et al. 2013). Of particular concern is that grassland plant species richness in GTA decreased most strongly when extractable soil P increased from the lowest to intermediate levels within the P gradient studied (Chapter 1, Fig. 2), pointing out that even a minor enhancement of plant-available $\mathrm{P}$ might compromise plant diversity. Preventing any artificial $\mathrm{P}$ input thus seems crucial in order to preserve plant species richness in semi-natural grasslands.

Not only direct additions of nutrients, but also the management can affect soil nutrient pools (Rumpel et al. 2015). For example, grazing over many years has been associated with decreasing availability of soil $\mathrm{P}$ in grazed grassland areas (Mládková et al. 2015). Benefits of grazing for the conservation of semi-natural grasslands might therefore also involve specific interactions between soil chemical properties. This note bridges the gap to the second main topic of this thesis-grazing by wild red deer.

\section{Vegetation responses to grazing by wild red deer}

A fundamental insight from the three-year grazing experiment in GTA is that wild red deer can remove forage from semi-natural open habitats in a quantity comparable to the annual biomass removal by domestic herbivores in stocking rates commonly 
applied in conservation grazing systems (Chapter 2). In spite of the differing productivity and associated grazing requirements of the two studied habitat types, grasslands and heathlands, red deer grazing proved beneficial in both habitat types. In that regard, the observed habitat-type-specific seasonal variation in red deer forage removal turned out to be important:

In heathlands, the removal of biomass by red deer was significant in the winter but not in the summer period (Chapter 2, Fig. 1b). This is promising news to heathland conservation, because earlier research has cautioned that severe grazing during the summer could affect Calluna detrimentally (Gimingham 1989). The relatively high annual productivity, along with further vegetation characteristics of the studied heathlands, suggested that these stands represent the early building phase of the Calluna life cycle. The considerable removal of up to $60 \%$ of the annually produced heathland vegetation biomass by red deer thus did not seem to compromise heather vitality in GTA. Comparing the vegetation development in open, continuously grazed plots and fenced plots, from which red deer were excluded over three years, gave further indications of a favourable habitat quality in the heathlands grazed by red deer (Chapter 3). Most conspicuously, the percent cover of bare soil decreased continuously in heathlands when red deer were fenced off, while the number of woody plant individuals sharply increased (Chapter 3, Figs 4, 6). These findings suggest that red deer grazing can contribute to the total biodiversity in heathlands by creating suitable habitat conditions for species dependent on bare soil (Bell et al. 2001; Chytrý et al. 2001; Cameron and Leather 2012; Henning et al. 2017). Moreover, consistent with the main threats reported for European dry heaths, the experimental results illustrate that this habitat type is highly susceptible to succession when grazing is lacking.

Another threat, primarily described for heathlands subject to intense livestock grazing, is the displacement of heather by grasses (Newton et al. 2009; Fagúndez 2012). During the study period in GTA, the estimated percentage contribution of grasses to the total aboveground biomass remained constant in the open, continuously grazed plots (data not shown). In addition, the local forestry staff responsible for the heathland management in GTA did not observe an increase in grass cover in heathlands over time. Therefore, the present study gives no reason to assume that grazing by wild red deer might relate to an increase in graminoid cover interfering with heathland conservation aims.

While it has been noted that a sustainable heathland management often needs to combine grazing with additional, more intensive management interventions (Härdtle et al. 2009; Fagúndez 2012), this does not seem to be necessary in GTA, where red deer grazing alone apparently maintained favourable heathland habitat quality. However, no information was available regarding past military activities, which might have caused occasional supplementary disturbances in our study sites (e.g. fire due to ordnance impact) long before the beginning of the study period. Taken as a whole, the results from the experimental study in GTA make the case for considering grazing by wild red deer as a suitable management strategy for heathlands, similar to livestock grazing at appropriate stocking rates (Gimingham 1992; Fagúndez 2012). 
For effectively conserving semi-natural grasslands communities by grazing, it is usually necessary to prevent the accumulation of unpalatable dead plant material, which is unlikely to be consumed by herbivores (Crofts and Jefferson 1999). Thus, when productivity is high in grasslands at the beginning of the vegetation period, concomitant high forage removal is required. Red deer grazing in GTA fulfilled this precondition, as the forage removal by red deer in grasslands peaked in spring and early summer (Chapter 2, Fig. 1a). This could be well explained by the forage maturation hypothesis (Fryxell 1991; Mysterud et al. 2017; Debeffe et al. 2017), predicting that red deer, being intermediately foraging herbivores (Hofmann 1989), select for easily digestible and highly nutritious forage as provided by grassland vegetation in early phenological stages. The experimental exclusion of red deer from permanent plots in GTA corroborated that red deer grazing can actually reduce the vegetation height and prevent the accumulation of litter (Chapter 3, Figs 3, 5). These findings contribute to explain the changes in grassland plant community composition observed after three years of red deer exclusion (Chapter 3, Figs 1, 2). The reduced plant diversity in fenced plots might stem from increased competition for light (Huisman et al. 1999; Bakker et al. 2006) and increased abundance of dominant species in the absence of grazing (Koerner et al. 2018) as well as from impaired germination and establishment of plant species due to litter accumulation (Ruprecht et al. 2010; Kelemen et al. 2013).

In a relatively productive habitat type, such as lowland hay meadows, the biomass removal by wild red deer alone, however, might not be sufficient as a single management measure in the long term. For one thing, we saw a trend of biomass accumulation over the three study years in the untreated grassland plots, where red deer grazing was the only management (Chapter 2, Fig. S3a). In addition, pairwise comparisons of open and fenced plots showed that the increased plant species diversity in the open plots was only significant when the grassland was also mown (Chapter 3, Table S2). Hence, it could prove advantageous to combine red deer grazing with additional management measures in grasslands in order to maximize conservation benefits.

\section{Synergies between additional grassland management and red deer grazing}

The grazing experiment in GTA included burning and mowing as additional grassland treatments. The underlying hypothesis was that additional biomass removal could increase the grassland attractiveness to red deer (Taylor et al. 2004; Cromsigt and Olff 2008; Fuhlendorf et al. 2009; Allred et al. 2011) and thereby provide the opportunity to influence the spatial distribution of red deer grazing impact. With regard to burning, the study results were not conclusive, which was probably related to the limited success of the burning treatment on two out of five study sites due to insufficient fuel (Hobbs et al. 1991) in the first two study years. Consequently, while prescribed fire has been used to enhance the quality and availability of forage for red deer in Northern America since the 1980s (Sittler et al. 2019), reasonably assessing the applicability and usefulness of a fire-based management approach for red deer in European semi-natural grasslands remains beyond the scope of the present work. Future studies should make a new attempt to assess the efficacy of burning as a 
means to influence the habitat use and grazing impact of red deer, because burning might be a more practical management option than mechanical biomass removal under certain conditions, e.g. in military impact areas (Montiel and Kraus 2010). By contrast, experimental evidence in favour of the basic hypothesis emerged with regard to mowing: First, mowing enhanced the productivity and improved the forage quality in the late season after mowing (Chapter 2, Figs 1a, 2a). Second, mowing increased the proportion of the annually produced biomass removed by red deer (considering that mowing also removed a certain fraction from the annual productivity; c.f. Chapter 2, Table 2). And third, red deer forage removal increased significantly with increasing productivity and forage quality (i.e. crude protein concentration; Chapter 2, Tables S6, S7). That mown plots were indeed more attractive than burnt or untreated plots was substantiated by the elevated frequency of red deer occurrence determined by cameras surveilling the open plots (Chapter 3, Table 1). The increased use of mown areas by red deer translated into the most pronounced differences between open and fenced plots in terms of plant diversity (Chapter 3, Figs 1, S3) and sward height (Chapter 3, Fig. 3). In sum, these results allow drawing two main conclusions. Firstly, as hypothesised, mowing could serve as a means to increase the local habitat use and forage removal of red deer in seminatural grasslands. Earlier studies have suggested that the relative attractiveness of a habitat and its spatial arrangement with other habitat types affect the grazing intensity by red deer (Clarke et al. 1995; Gordon et al. 2004; Moore et al. 2015). Therefore, further experimental studies are now required to test if mowing actually stimulates free-ranging red deer to also make increased use of habitats adjacent to the mown areas. Secondly, mowing in combination with red deer grazing seems to be an ideal strategy for creating suitable habitat conditions for highly diverse plant communities in semi-natural grasslands. Different explanations for this synergistic effect are conceivable. For instance, when the successive biomass removal by grazing is complemented by mowing and biomass harvesting, light competition could be most effectively reduced, while simultaneously promoting temporal stability in community evenness (Mortensen et al. 2018). Additionally, mowing and grazing could favour different plant functional groups (Mládková et al. 2015). However, as the red deer exclusion experiment in GTA encompassed three years, but plant communities might respond rather slowly and discontinuously to changes in management (Bullock et al. 2001; Dumont et al. 2011), it would be desirable to supplement the present findings by exclusion experiments including different management regimes running over an extended period of time (Bakker et al. 2016). Such future studies on synergistic effects between red deer grazing and additional grassland management could also experimentally vary the frequency of additional management measures, which could help to optimize the costs and benefits of conservations efforts (Tälle et al. 2018).

Based on the results so far, the potential benefits from grazing by wild red deer for the conservation of semi-natural open habitats seem persuasive. Actually implementing grazing by wild red deer in applied conservation management, however, requires consideration of the societal, organisational and ecological 
conditions_-some of which differ considerably between the study area, GTA, and ordinary cultural landscapes.

\section{Conservation grazing by wild red deer-future perspectives and open questions}

Assessing the scope of application for the insights from the present work first requires to acknowledge that conservation grazing by wild red deer, obviously, is only an option in regions permanently inhabited by this species. Although associated with certain advantages when it comes to the practical implementation (as pointed out in the Introduction), in this regard, grazing by wild red deer has to be considered as less flexible than grazing by domestic herbivores, which could, theoretically, be moved as necessary to any target area.

During the past decades, red deer populations have increased throughout Europe (Putman and Moore 1998; Côté et al. 2004; Milner et al. 2006; Burbaitè and Csányi 2010). Habitat use and movement of red deer are, however, substantially restricted in most countries (Linnell et al. 2015). In many German federal states, strict hunting of red deer outside of specifically designated areas has been required by law since the 1950s; but certain populations also occur outside of these defined areas, so that the species range covers approximately $25 \%$ of Germany (Kinser et al. 2010; Deutsche Wildtier Stiftung 2017a; Deutsche Wildtier Stiftung 2017b). Intensive management and manipulation of red deer populations, including hunting, even extends into protected areas (Günther and Heurich 2013; Linnell et al. 2015). The main reason for this widespread policy are concerns about damage to commercial forests (Côté et al. 2004; Deutsche Wildtier Stiftung 2017b). Unfortunately, the various ways by which human activities, such as hunting or recreation, disturb red deer, aggravate the potential for conflict as the animals respond by seeking cover in forests (Deutsche Wildtier Stiftung 2017c; Wisdom et al. 2018; Westekemper et al. 2018). The present work may contribute to ease the controversial public debate concerning red deer by highlighting that an adapted wildlife management regime can reduce the potential for conflict between red deer and forestry. In the study area GTA, human disturbances were mainly limited to military land use, which enabled the resident red deer to leave forested areas and forage in open habitats even during the daytime (Meißner et al. 2013, L. Richter, unpublished). Similarly, in a Natura 2000 area in the Italian PreAlps, the abolition of hunting has encouraged red deer to make use of grasslands (Marchiori et al. 2012).

While it seems very challenging to establish a coherent wildlife management regime pushing red deer out of forests and pulling them into the open landscapes in highly fragmented landscapes with many landowners and stakeholders (Beguin et al. 2016), sizable areas suitable to such an approach exist, such as core zones of national parks or other large nature reserves. Additionally, in Germany, the National Strategy on Biological Diversity aims at designating $2 \%$ of the national territory as large-scale wilderness areas. Natural processes should be allowed in these areas without or with only very slight human interference (Schumacher et al. 2018). Grazing by wild red deer could hence be an opportunity to enhance the natural and 'wild' character intended for those wilderness areas. In addition, wild red deer could prove 
particularly advantageous not only for active military training areas, such as GTA, but also for decommissioned former military training areas. Since the end of the Cold War in 1989, an estimated total area of 1.5 million ha of military land has been abandoned in Europe (Ellwanger and Reiter 2019). The cessation of military activities is often followed by shrub and tree encroachment, critically threatening the persistence of disturbance-dependent communities (Jentsch et al. 2009). However, in many cases, appropriate conservation measures are not yet implemented because these areas are often highly contaminated by unexploded ordnance (Ellwanger and Reiter 2019).

From an applied conservation point of view, there are some unanswered questions regarding the practical implementation of grazing by wild red deer. For instance, despite the challenges related to estimating or controlling red deer population size (Hagen et al. 2018), practicians may ask which local density of red deer is required for effectively contributing to the preservation of open habitats. As a general rule, the number of red deer obviously needs to be considered in relation to the available area of open habitats. However, as the foraging impact of wild red deer depends much more on their spatial distribution within the landscape than on population density (Gordon et al. 2004; Moore et al. 2015), a general estimate regarding the minimum size of a red deer population needed for meeting the grazing requirements of open habitat types is not possible. The exemplary case in GTA, where the red deer abundance is comparatively high, shows that the wildlife management is a key element for successfully implementing grazing by wild red deer in open habitats. In GTA, targeted hunting and land management are combined in a push-and-pull strategy to deter red deer from forests and encourage them to forage in open landscapes (Meißner et al. 2013). The question how long it may usually take until red deer have sufficiently accommodated to a new wildlife management regime remains to be addressed by future studies, as the way of managing wildlife in GTA had already been developed over a long time before the present study started.

Besides an adapted hunting regime, another prerequisite for a successful conservation management of open habitats based on grazing by wild red deer is to supply the animals within the target area with all essential resources throughout the year. For example, it should be considered that the availability of forage provided by open as well as forested habitats decreases in winter (Smolko et al. 2018). In GTA, red deer are provisioned in winter with haylage produced from vegetation biomass cut in summer from meadows within the area; although the usefulness of supplementary or diversionary feeding of wild ungulates in general is highly debated (Milner et al. 2014; Beguin et al. 2016). Therefore, the relevance of supplementary or divisionary feeding in the context of a wildlife management system aiming at increasing red deer habitat use of open landscapes requires further investigations.

As red deer can play an important role for the endozoochorous dispersal of plant species, especially for early-successional (Iravani et al. 2011) and many rare and endangered species (Wichelhaus 2017), further experimental research could attempt to develop habitat restauration strategies based on red deer grazing. For example, seed mixtures containing rare plant species could be sown in open areas highly attractive to red deer. Extensive fecal sampling could show if seeds of these plant 
species can subsequently be retrieved from red deer feaces and to which locations the seeds are dispersed.

To attain a comprehensive picture of red deer as ecosytem engineer, also the influence of its presence on other species groups should receive further attention (c.f. Spalinger et al. 2012; Lilleeng et al. 2018; Horák et al. 2018), epecially in comparison to livestock. For instance, a conservation grazing approach based on wild red deer could favour faunal biodiversity because wild herbivores do not receive antiparasitic treatment, which is commonly applied to livestock and can have harmful side-effects on invertebrates living in dung or soil (Förster et al. 2011; Sutton et al. 2014).

Additionally, in order to promote the practical implementation of grazing by freeranging red deer for the conservation of semi-natural open habitats, research on the potential interactions between red deer and domestic grazers (DeGabriel et al. 2011; Pérez-Barbería et al. 2015) is required. Another intriguing task for future reseach is investigating if and how the habitat use and grazing impact of red deer will change in response to the presence of natural predators - a question that has become topical also in Germany, which is currently being recolonized by wolves, especially via military training areas (Reinhardt et al. 2019).

\section{Conclusions}

Taking advantage of a study area where military land use has prevented industrial agricultural practices during the past century, the present thesis has improved our understanding of vegetation patterns under close-to-natural soil nutrient conditions (Chapter 1). The identified significant relationships between soil chemical parameters and plant species richness have meaningful implications for the conservation of semi-natural open habitat types. Preventing acidification in heathlands and soil $\mathrm{P}$ concentration in grasslands from increasing might be essential preconditions for maintaining species-rich plant communities.

Using an experimental approach, this thesis has explored how grazing by wild and free-ranging red deer contributes to vegetation processes in these semi-natural open habitats (Chapter $2 \& 3$ ). From an applied conservation perspective, the results regarding biomass removal and the development of habitat quality strongly argue for beneficial effects of wild red deer in both heathlands and grasslands. Transferring the wildlife grazing regime as practised in GTA to other conservation target areas, however, requires certain adaptations of habitat and wildlife management conventions in order to encourage red deer to make use of open habitats for foraging. Overall, in accord with the recent call to consider wild ungulates as an integral part of both ecosystems and ecosystem management (Apollonio et al. 2017), the present work supports considering red deer not (only) as a potential cause of economic damage in forests but as an ecosystem engineer that can contribute to the preservation of semi-natural open habitats. 


\section{References}

Allred BW, Fuhlendorf SD, Engle DM, Elmore RD. 2011. Ungulate preference for burned patches reveals strength of fire-grazing interaction. Ecology and Evolution 1:132-144.

Apollonio M, Belkin VV, Borkowski J, Borodin OI, Borowik T, Cagnacci F, Danilkin AA, Danilov PI, Faybich A, Ferretti F, et al. 2017. Challenges and science-based implications for modern management and conservation of European ungulate populations. Mammal Research 62:209-217.

Bakker ES, Gill JL, Johnson CN, Vera FWM, Sandom CJ, Asner GP, Svenning J-C. 2016. Combining paleo-data and modern exclosure experiments to assess the impact of megafauna extinctions on woody vegetation. Proceedings of the National Academy of Sciences 113:847-855.

Bakker ES, Ritchie ME, Olff H, Milchunas DG, Knops JMH. 2006. Herbivore impact on grassland plant diversity depends on habitat productivity and herbivore size. Ecology Letters 9:780_ 788.

Beguin J, Tremblay J-P, Thiffault N, Pothier D, Côté SD. 2016. Management of forest regeneration in boreal and temperate deer-forest systems: challenges, guidelines, and research gaps. Ecosphere 7:1-16.

Bell JR, Wheater CP, Cullen WR. 2001. The implications of grassland and heathland management for the conservation of spider communities: a review. Journal of Zoology 255:377-387.

Bullock JM, Joe Franklin, Stevenson MJ, Jonathan Silvertown, Coulson SJ, Gregory SJ, Tofts R. 2001. A plant trait analysis of responses to grazing in a long-term experiment. Journal of Applied Ecology 38:253-267.

Burbaitè L, Csányi S. 2010. Red deer population and harvest changes in Europe. Acta Zoologica Lituanica 20:179-188.

Cameron KH, Leather SR. 2012. Heathland management effects on carabid beetle communities: the relationship between bare ground patch size and carabid biodiversity. Journal of Insect Conservation 16:523-535.

Ceulemans T, Merckx R, Hens M, Honnay O. 2013. Plant species loss from European semi-natural grasslands following nutrient enrichment - is it nitrogen or is it phosphorus? Global Ecology and Biogeography 22:73-82.

Chytrý M, Sedláková I, Tichý L. 2001. Species richness and species turnover in a successional heathland. Applied Vegetation Science 4:89-96.

Clarke JL, Welch D, Gordon IJ. 1995. The Influence of Vegetation Pattern on the Grazing of Heather Moorland by Red Deer and Sheep. II. The Impact on Heather. Journal of Applied Ecology 32:177-186.

Côté SD, Rooney TP, Tremblay J-P, Dussault C, Waller DM. 2004. Ecological Impacts of Deer Overabundance. Annual Review of Ecology, Evolution, and Systematics 35:113-147.

Critchley CNR, Chambers BJ, Fowbert JA, Bhogal A, Rose SC, Sanderson RA. 2002. Plant species richness, functional type and soil properties of grasslands and allied vegetation in English Environmentally Sensitive Areas. Grass and Forage Science 57:82-92.

Crofts A, Jefferson RG, editors. 1999. The Lowland Grassland Management Handbook. 2nd ed. English Nature and Wildlife Trusts.

Cromsigt JPGM, Olff H. 2008. Dynamics of grazing lawn formation: an experimental test of the role of scale-dependent processes. Oikos 117:1444-1452.

Debeffe L, Rivrud IM, Brekkum Ø, Meisingset EL, Mysterud A. 2017. Implications of the forage maturation hypothesis for activity of partially migratory male and female deer. Ecosphere 8:e02050.

DeGabriel JL, Albon SD, Fielding DA, Riach DJ, Westaway S, Irvine RJ. 2011. The presence of sheep leads to increases in plant diversity and reductions in the impact of deer on heather. Journal of Applied Ecology 48:1269-1277.

Deutsche Wildtier Stiftung. 2017a. Rotwildverbreitung in Deutschland [Internet]. [cited 2019 Mar 21]. Available from: https://www.rothirsch.org/wissen/rotwildverbreitung-in-deutschland/

Deutsche Wildtier Stiftung. 2017b. Position der Deutschen Wildtier Stiftung zu Rotwildbezirken [Internet]. [cited 2019 Mar 21]. Available from: https://www.rothirsch.org/unserepositionen/jagdpolitik-der-laender/

Deutsche Wildtier Stiftung. 2017c. Konflikte um das Rotwild [Internet]. [cited 2019 Mar 21]. Available from: https://www.rothirsch.org/wissen/konfliktfelder/ 
Dumont B, Carrère P, Ginane C, Farruggia A, Lanore L, Tardif A, Decuq F, Darsonville O, Louault F. 2011. Plant-herbivore interactions affect the initial direction of community changes in an ecosystem manipulation experiment. Basic and Applied Ecology 12:187-194.

Ellwanger G, Reiter K. 2019. Nature conservation on decommissioned military training areas German approaches and experiences. Journal for Nature Conservation 49:1-8.

Fagúndez J. 2012. Heathlands confronting global change: drivers of biodiversity loss from past to future scenarios. Annals of Botany 111:151-172.

Förster B, Boxall A, Coors A, Jensen J, Liebig M, Pope L, Moser T, Römbke J. 2011. Fate and effects of ivermectin on soil invertebrates in terrestrial model ecosystems. Ecotoxicology 20:234245.

Fryxell JM. 1991. Forage quality and aggregation by large herbivores. American Naturalist:478-498.

Fuhlendorf SD, Engle DM, Kerby J, Hamilton R. 2009. Pyric Herbivory: Rewilding Landscapes through the Recoupling of Fire and Grazing. Conservation Biology 23:588-598.

Gilbert J, Gowing D, Wallace H. 2009. Available soil phosphorus in semi-natural grasslands: assessment methods and community tolerances. Biological Conservation 142:1074-1083.

Gimingham CH. 1992. The Lowland Heathland Management Handbook. Peterborough, UK: English Nature.

Gordon IJ, Hester AJ, Festa-Bianchet M. 2004. REVIEW: The management of wild large herbivores to meet economic, conservation and environmental objectives. Journal of Applied Ecology 41:1021-1031.

Günther S, Heurich M. 2013. Assessment of the naturalness of the red deer management in central European national parks. Allgemeine Forst- und Jagdzeitung 184:1-16.

Güsewell S. 2004. N : P ratios in terrestrial plants: variation and functional significance. New Phytologist 164:243-266.

Hagen R, Haydn A, Suchant R. 2018. Estimating red deer (Cervus elaphus) population size in the Southern Black Forest: the role of hunting in population control. European Journal of Wildlife Research 64:42.

Härdtle W, Oheimb G von, Gerke A-K, Niemeyer M, Niemeyer T, Assmann T, Drees C, Matern A, Meyer H. 2009. Shifts in N and P Budgets of Heathland Ecosystems: Effects of Management and Atmospheric Inputs. Ecosystems 12:298-310.

Hautier Y, Niklaus PA, Hector A. 2009. Competition for Light Causes Plant Biodiversity Loss After Eutrophication. Science 324:636-638.

Hejcman M, Češková M, Schellberg J, Pätzold S. 2010. The Rengen Grassland Experiment: Effect of Soil Chemical Properties on Biomass Production, Plant Species Composition and Species Richness. Folia Geobotanica 45:125-142.

Henning K, Oheimb G von, Härdtle W, Fichtner A, Tischew S. 2017. The reproductive potential and importance of key management aspects for successful Calluna vulgaris rejuvenation on abandoned Continental heaths. Ecology and Evolution 7:2091-2100.

Hobbs NT, Schimel DS, Owensby CE, Ojima DS. 1991. Fire and grazing in the tallgrass prairie: contingent effects on nitrogen budgets. Ecology 72:1374-1382.

Hofmann RR. 1989. Evolutionary steps of ecophysiological adaptation and diversification of ruminants: a comparative view of their digestive system. Oecologia 78:443-457.

Horák J, Pavlíček J, Kout J, Halda JP. 2018. Winners and losers in the wilderness: response of biodiversity to the abandonment of ancient forest pastures. Biodiversity and Conservation 27:3019-3029.

Huisman J, Grover JP, Van der Wal R, Van Andel J. 1999. Competition for light, plant-species replacement and herbivore abundance along productivity gradients. In: Olff $\mathrm{H}$, Brown VK, Drent RH, editors. Herbivores, Plants and Predators. Oxford, UK: Blackwell Science; p. 239-269.

Iravani M, Schütz M, Edwards PJ, Risch AC, Scheidegger C, Wagner HH. 2011. Seed dispersal in red deer (Cervus elaphus L.) dung and its potential importance for vegetation dynamics in subalpine grasslands. Basic and Applied Ecology 12:505-515.

Janssens F, Peeters A, Tallowin JRB, Bakker JP, Bekker RM, Fillat F, Oomes MJM. 1998. Relationship between soil chemical factors and grassland diversity. Plant and Soil 202:69-78. 
Jentsch A, Friedrich S, Steinlein T, Beyschlag W, Nezadal W. 2009. Assessing conservation action for substitution of missing dynamics on former military training areas in Central Europe. Restoration Ecology 17:107-116.

Kanakidou M, Myriokefalitakis S, Daskalakis N, Fanourgakis G, Nenes A, Baker AR, Tsigaridis K, Mihalopoulos N. 2016. Past, Present, and Future Atmospheric Nitrogen Deposition. Journal of the Atmospheric Sciences 73:2039-2047.

Kelemen A, Török P, Valkó O, Miglécz T, Tóthmérész B. 2013. Mechanisms shaping plant biomass and species richness: plant strategies and litter effect in alkali and loess grasslands. Journal of Vegetation Science 24:1195-1203.

Kinser A, Koope K, Freiherr von Münchhausen H. 2010. Die Rotwildverbreitung in Deutschland. AFZ-Der Wald 5:32-34.

Kleijn D, Bekker RM, Bobbink R, De Graaf MCC, Roelofs JGM. 2008. In search for key biogeochemical factors affecting plant species persistence in heathland and acidic grasslands: a comparison of common and rare species. Journal of Applied Ecology 45:680-687.

Koerner SE, Smith MD, Burkepile DE, Hanan NP, Avolio ML, Collins SL, Knapp AK, Lemoine NP, Forrestel EJ, Eby S, et al. 2018. Change in dominance determines herbivore effects on plant biodiversity. Nature Ecology \& Evolution 2:1925-1932.

Lilleeng MS, Rydgren K, Halvorsen R, Moe SR, Hegland SJ. 2018. Red deer structure the grounddwelling beetle community in boreal forest. Biodiversity and Conservation 27:2507-2525.

Linnell JDC, Kaczensky P, Wotschikowsky U, Lescureux N, Boitani L. 2015. Framing the relationship between people and nature in the context of European conservation. Conservation Biology 29:978-985.

Marchiori E, Sturaro E, Ramanzin M. 2012. Wild red deer (Cervus elaphus L.) grazing may seriously reduce forage production in mountain meadows. Italian Journal of Animal Science 11:e9.

Meißner M, Reinecke H, Herzog S. 2013. Vom Wald ins Offenland: Der Rothirsch auf dem Truppenübungsplatz Grafenwöhr. Raum-Zeit-Verhalten, Lebensraumnutzung, Management. 2nd ed. Kassel, DE: Frank Fornaçon.

Milner JM, van Beest FM, Schmidt KT, Brook RK, Storaas T. 2014. To feed or not to feed? Evidence of the intended and unintended effects of feeding wild ungulates. Journal of Wildlife Management 78:1322-1334.

Milner JM, Bonenfant C, Mysterud A, Gaillard J-M, Csányi S, Stenseth NC. 2006. Temporal and spatial development of red deer harvesting in Europe: biological and cultural factors. Journal of Applied Ecology 43:721-734.

Mládková P, Mládek J, Hejduk S, Hejcman M, Cruz P, Jouany C, Pakeman RJ. 2015. High-naturevalue grasslands have the capacity to cope with nutrient impoverishment induced by mowing and livestock grazing. Journal of Applied Ecology 52:1073-1081.

Montiel C, Kraus DT, editors. 2010. Best practices of fire use: prescribed burning and suppression: fire programmes in selected case-study regions in Europe. Joensuu, FI: European Forest Institute.

Moore EK, Britton AJ, Iason G, Pemberton J, Pakeman RJ. 2015. Landscape-scale vegetation patterns influence small-scale grazing impacts. Biological Conservation 192:218-225.

Mortensen B, Danielson B, Harpole WS, Alberti J, Arnillas CA, Biederman L, Borer ET, Cadotte MW, Dwyer JM, Hagenah N, et al. 2018. Herbivores safeguard plant diversity by reducing variability in dominance. Journal of Ecology 106:101-112.

Mysterud A, Vike BK, Meisingset EL, Rivrud IM. 2017. The role of landscape characteristics for forage maturation and nutritional benefits of migration in red deer. Ecology and Evolution 7:4448-4455.

Newton AC, Stewart GB, Myers G, Diaz A, Lake S, Bullock JM, Pullin AS. 2009. Impacts of grazing on lowland heathland in north-west Europe. Biological Conservation 142:935-947.

Pérez-Barbería FJ, Small M, Hooper RJ, Aldezabal A, Soriguer-Escofet R, Bakken GS, Gordon IJ. 2015. State-Space Modelling of the Drivers of Movement Behaviour in Sympatric Species. PLOS ONE 10:e0142707.

Putman RJ, Moore NP. 1998. Impact of deer in lowland Britain on agriculture, forestry and conservation habitats. Mammal Review 28:141-164.

Reinhardt I, Kluth G, Nowak C, Szentiks CA, Krone O, Ansorge H, Mueller T. 2019. Military training areas facilitate the recolonization of wolves in Germany. Conservation Letters 0:e12635. 
Roem WJ, Berendse F. 2000. Soil acidity and nutrient supply ratio as possible factors determining changes in plant species diversity in grassland and heathland communities. Biological Conservation 92:151-161.

Rumpel C, Crème A, Ngo PT, Velásquez G, Mora ML, Chabbi A. 2015. The impact of grassland management on biogeochemical cycles involving carbon, nitrogen and phosphorus. Journal of soil science and plant nutrition 15:353-371.

Ruprecht E, Enyedi MZ, Eckstein RL, Donath TW. 2010. Restorative removal of plant litter and vegetation 40 years after abandonment enhances re-emergence of steppe grassland vegetation. Biological Conservation 143:449-456.

Schumacher H, Finck P, Riecken U, Klein M. 2018. More wilderness for Germany: Implementing an important objective of Germany's National Strategy on Biological Diversity. Journal for Nature Conservation 42:45-52.

Sittler KL, Parker KL, Gillingham MP. 2019. Vegetation and prescribed fire: Implications for stone's sheep and elk. The Journal of Wildlife Management 83:393-409.

Smolko P, Veselovská A, Kropil R. 2018. Seasonal dynamics of forage for red deer in temperate forests: importance of the habitat properties, stand development stage and overstorey dynamics. Wildlife Biology 2018:1-10.

Spalinger LC, Haynes AG, Schütz M, Risch AC. 2012. Impact of wild ungulate grazing on Orthoptera abundance and diversity in subalpine grasslands. Insect Conservation and Diversity 5:444452.

Sutton G, Bennett J, Bateman M. 2014. Effects of ivermectin residues on dung invertebrate communities in a UK farmland habitat. Insect Conservation and Diversity 7:64-72.

Tälle M, Deák B, Poschlod P, Valkó O, Westerberg L, Milberg P. 2018. Similar effects of different mowing frequencies on the conservation value of semi-natural grasslands in Europe. Biodiversity and Conservation 27:2451-2475.

Taylor N, Knight JE, Short JJ. 2004. Fall Cattle Grazing versus Mowing to Increase Big-Game Forage. Wildlife Society Bulletin 32:449-455.

Van Den Berg LJL, Dorland E, Vergeer P, Hart MAC, Bobbink R, Roelofs JGM. 2005. Decline of acid-sensitive plant species in heathland can be attributed to ammonium toxicity in combination with low pH. New Phytologist 166:551-564.

Westekemper K, Reinecke H, Signer J, Meißner M, Herzog S, Balkenhol N. 2018. Stay on trails effects of human recreation on the spatiotemporal behavior of red deer Cervus elaphus in a German national park. Wildlife Biology [Internet] [cited 2019 Mar 21]; 2018. Available from: https://bioone.org/journals/Wildlife-Biology/volume-2018/issue-1/wlb.00403/Stay-ontrails--effects-of-human-recreation-on-the/10.2981/wlb.00403.full

Wichelhaus A. 2017. Von hier nach dort: Endozoochorer Transport von Pflanzendiasporen durch den Rothirsch - Potenzial für Arten des wertgebenden Offenlands. In: Kinser A, Münchhausen M, editors. Der Hirsch als Naturschützer - Konsequenzen für den Umgang mit Huftieren in Großschutzgebieten Tagungsband zum 8 Rotwildsymposium der Deutschen Wildtier Stiftung vom 07 bis 09 Juli 2016. Baden-Baden.

Wisdom MJ, Preisler HK, Naylor LM, Anthony RG, Johnson BK, Rowland MM. 2018. Elk responses to trail-based recreation on public forests. Forest Ecology and Management 411:223-233. 


\section{Acknowledgements}

The project was supported by funds of German government's Special Purpose Fund held at Landwirtschaftliche Rentenbank [28 RZ 7007]. I thank the Federal Forests Division (Bundesforst) of the German Institute for Federal Real Estate (Bundesanstalt für Immobilienaufgaben) and the Institut für Wildbiologie Göttingen und Dresden e.V. for close cooperation and support.

This thesis would not have been possible without the guidance and support of many people.

Firstly, I would like to express my sincere gratitude to Prof. Dr. Isselstein for the opportunity to become a member of the Grassland group and his kind and encouraging supervision of my work. His curiosity and enthusiasm for science were a great motivation for me. I would also like to thank my second supervisor, Prof. Dr. Niko Balkenhol, for his support and the hospitable and cooperative atmosphere in many project meetings in the rooms of the Wildlife Sciences. I am very obliged to Prof. Dr. Teja Tscharntke, who kindly agreed to become the third member of my thesis committee. Moreover, I am very glad that Prof. Dr. Bergmeier, Prof. Dr. Leuschner and Prof. Dr. Matthias Waltert were interested in my research and joined the examination board.

Special thanks go to Dr. Bettina Tonn for her excellent, invaluable and cordial guidance in all aspects of research, such as statistics, good scientific practice, writing papers, giving talks and much more. I learned very much from you!

Regarding the practical implementation of the present work, I am obliged to Marcus Meißner, who initiated the project in Grafenwöhr, organized the local infrastructure and coordinated the cooperation with local authorities. For the smooth running of fieldwork under the challenging circumstances of an active military training area, I have to give great credit to the Federal Forest Division Grafenwöhr, especially to the forestry district leaders Ulrich Schomann und Andreas Irle. Being in the field, it was extremely reassuring to know that we could count on their support in any kind of situation. It would not have been possible to accomplish all the fieldwork on my own; therefore, I am tremendously thankful for all the help from students and friends including my brother Christian, who accompanied me to Grafenwöhr, measured sward height, cut calibration samples, cooked substantial and delicious meals and made the field trips always a most enjoyable experience! To Hans Georg Stroh, who carried out the vegetation surveys in Grafenwöhr, I owe a lot because he invited me to join his field trips and thereby helped me to refresh and expand my humble knowledge in plant species determination.

For help with fieldwork and much more, I would like to thank my $\mathrm{PhD}$ colleagues Christoph Raab, Laura Richter, and Anya Wichelhaus-I loved spending time together! Our complementary scientific background has contributed very much to broaden my mind and helped me to gain new insights in differed fields of science. I also learned a lot from the cooperative work and fruitful discussions with the whole Grafenwöhr research team and the members of the Grassland Science group. I am 
much obliged to Barbara Hohlmann, who introduced me to the laboratory methods used in grassland science and express my gratitude for all the help I received -also from other staff members - with the processing and analysing of my samples. I consider myself very lucky to have had great office mates and colleagues; both at work and in the spare time I greatly enjoyed your company! Thanks for the amazing work atmosphere and the numerous refreshing coffee breaks, which helped enormously to keep my spirits up all the time.

Finally, I would like to thank my family for their constant support, without which I would not have been able to lead a life commuting between Körle and Göttingen, village and city, stable and office, dog walking and paper work, horses and red deer... Last but not least, I am grateful for all the happy moments I spent with my two- and four-legged friends, who made sure that I kept a healthy work-life balance throughout my PhD work. 


\section{List of Publications}

\section{Journal publications-published}

Riesch F, Tonn B, Meißner M, Balkenhol N, Isselstein J. 2019. Grazing by wild red deer: Management options for the conservation of semi-natural open habitats. Journal of Applied Ecology 56:1311- 1321.

Riesch F, Stroh HG, Tonn B, Isselstein J. 2018. Soil pH and phosphorus drive species composition and richness in semi-natural heathlands and grasslands unaffected by twentieth-century agricultural intensification. Plant Ecology \& Diversity 11:239-253.

Fischer C, Gayer C, Kurucz K, Riesch F, Tscharntke T, Batáry P. 2018. Ecosystem services and disservices provided by small rodents in arable fields: Effects of local and landscape management. Journal of Applied Ecology 55:548-558.

Happe A-K ${ }^{1}$, Riesch F ${ }^{1}$, Rösch V, Gallé R, Tscharntke T, Batáry P. 2018. Small-scale agricultural landscapes and organic management support wild bee communities of cereal field boundaries. Agriculture, Ecosystems \& Environment 254:92-98. ${ }^{1}$ Equally contributing authors.

Batáry P, Gallé R, Riesch F, Fischer C, Dormann CF, Mußhoff O, Császár P, Fusaro S, Gayer C, Happe A-K, Kurucz K, Molnár D, Rösch V, Wietzke A, Tscharntke T. 2017. The former Iron Curtain still drives biodiversity-profit trade-offs in German agriculture. Nature Ecology \& Evolution 1:1279-1284.

\section{Journal publications-submitted}

Riesch F, Stroh HG, Tonn B, Meißner M, Balkenhol N, Isselstein J. Grazing by wild red deer maintains characteristic vegetation of semi-natural open habitats: Evidence from a 3-year exclusion experiment. Applied Vegetation Science (submitted).

Raab C, Riesch F, Tonn B, Barrett B, Meißner M, Balkenhol N, Isselstein J. Targetoriented habitat and wildlife management: estimating forage quantity and quality of semi-natural grasslands with Sentinel-1 and Sentinel-2 data. Remote Sensing of Environment (submitted).

\section{Peer-reviewed conference papers}

Riesch F, Tonn B, Meißner M, Isselstein J. 2018. Grazing by free-ranging red deer: effective management for semi-natural grassland conservation? Grassland Science in Europe 23:401-403.

Riesch F, Stroh HG, Tonn B, Isselstein J. 2016. Phytodiversity in nutrient-poor heathlands and grasslands: How important are soil chemical factors? Grassland Science in Europe 21:669-671. 


\section{Further conference papers}

Riesch F, Meißner M, Raab C, Richter L. 2019. Gezielte Steuerung der Raumnutzung: Rothirsche und FFH-Offenlandmanagement. In: Bundesverband Beruflicher Naturschutz e. V. (BBN), editor: „Klarer Kurs - Naturschutz“ DNT Journal 2019 zum 34. Deutschen Naturschutztag vom 25. bis 29. September 2018. Kiel, 75-84.

Riesch F, Tonn B, Meißner M, Isselstein J. 2019. Beweidung mit wildlebenden Rothirschen: effektives Management zum Erhalt von FFH-Grünland? In: Kinser A, Münchhausen M, editors: Der Rothirsch in der Überzahl - Wege zu einer tierschutzgerechten Rotwildreduktion. Tagungsband zum 9. Rotwildsymposium der Deutschen Wildtier Stiftung 28. bis 30. Juni 2018. Bad Driburg, 142-146.

Meißner M, Maushake U, Balkenhol N, Herzog S, Isselstein J, Raab C, Reinecke H, Richter L, Riesch F, Signer J, Stroh HG, Tonn B. 2017. Erhalt von Offenlandschaften - wildlebende Rothirsche als Landschaftspfleger. In: Kinser A, Münchhausen M, editors: Der Hirsch als Naturschützer - Konsequenzen für den Umgang mit Huftieren in Großschutzgebieten. Tagungsband zum 8.

Rotwildsymposium der Deutschen Wildtier Stiftung vom 07. bis 09. Juli 2016. Baden-Baden, 48-59.

Riesch F, Tonn B, Meißner M, Isselstein J. 2017. Erhalt von Offenlandschaften wildlebende Rothirsche als Landschaftspfleger: Vegetationsökologie. In: Kinser A, Münchhausen M, editors: Der Hirsch als Naturschützer - Konsequenzen für den Umgang mit Huftieren in Großschutzgebieten. Tagungsband zum 8.

Rotwildsymposium der Deutschen Wildtier Stiftung vom 07. bis 09. Juli 2016. Baden-Baden, 178-183. 


\section{Thesis Declaration}

I hereby confirm that I have written this doctoral thesis independently, that I have not used other sources or facilities other than the ones mentioned, that I have not used unauthorized assistance and that I have not submitted this thesis previously in any form for another degree at any university or institution.

Friederike Riesch

Göttingen, 09. April 2019 